\title{
Regional sustainable development: barriers in practice : findings from policy, citizens, practitioners and monitoring
}

Citation for published version (APA):

van Zeijl-Rozema, A. E. (2011). Regional sustainable development: barriers in practice : findings from policy, citizens, practitioners and monitoring. [Doctoral Thesis, Maastricht University]. Datawyse / Universitaire Pers Maastricht. https://doi.org/10.26481/dis.20110512az

Document status and date:

Published: 01/01/2011

DOI:

10.26481/dis.20110512az

Document Version:

Publisher's PDF, also known as Version of record

Please check the document version of this publication:

- A submitted manuscript is the version of the article upon submission and before peer-review. There can be important differences between the submitted version and the official published version of record.

People interested in the research are advised to contact the author for the final version of the publication, or visit the DOI to the publisher's website.

- The final author version and the galley proof are versions of the publication after peer review.

- The final published version features the final layout of the paper including the volume, issue and page numbers.

Link to publication

\footnotetext{
General rights rights.

- You may freely distribute the URL identifying the publication in the public portal. please follow below link for the End User Agreement:

www.umlib.nl/taverne-license

Take down policy

If you believe that this document breaches copyright please contact us at:

repository@maastrichtuniversity.nl

providing details and we will investigate your claim.
}

Copyright and moral rights for the publications made accessible in the public portal are retained by the authors and/or other copyright owners and it is a condition of accessing publications that users recognise and abide by the legal requirements associated with these

- Users may download and print one copy of any publication from the public portal for the purpose of private study or research.

- You may not further distribute the material or use it for any profit-making activity or commercial gain

If the publication is distributed under the terms of Article $25 \mathrm{fa}$ of the Dutch Copyright Act, indicated by the "Taverne" license above, 
Regional Sustainable Development: Barriers in Practice Findings from policy, citizens, practitioners and monitoring

Annemarie van Zeijl-Rozema 
Cover illustration: carpet (detail), 2009, design by Claudy Jongstra. Collection Province of Limburg, Photography Alf Mertens.

Claudy Jongstra, born in 1963 in Limburg, is an artist who uses felt as a basic material. She has her own flock of Drenthe Heath sheep that produce her wool, and a botanical garden that provides her dyes. Not only does this allow her to work in an autonomous and sustainable way, but at the same time she preserves natural and cultural heritage. She uses a rare breed of sheep, plants threatened by extinction, and knowledge and techniques that were becoming forgotten. She has worked with well-known fashion designers and architects and has won a fair number of prizes.

(C) 2011 Annemarie van Zeijl-Rozema, Maastricht ISBN 9789461590510

Production: Datawyse | Universitaire Pers Maastricht 


\section{Regional Sustainable Development: Barriers in Practice}

Findings from policy, citizens, practitioners and monitoring

\section{Proefschrift}

ter verkrijging van de graad van doctor

aan de Universiteit Maastricht

op gezag van de Rector Magnificus

prof.mr. G.P.M.F. Mols

volgens het besluit van het College van Decanen,

in het openbaar te verdedigen op

donderdag 12 mei 2011 om 12.00 uur

door

Annemarie Elizabeth van Zeijl-Rozema

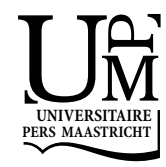




\section{Promotor}

Prof. dr. Pim Martens

\section{Co-promotor}

Dr. Ron Cörvers

\section{Beoordelingscommissie}

Prof. dr. René Kemp (voorzitter)

Prof. dr. ir. Louise O. Fresco (Universiteit van Amsterdam)

Prof. dr. Hans van Mierlo

Prof. dr. Arnim Wiek (Arizona State University)

This PhD research was supported by:

The Province of Limburg

The European Union Sixth Framework Programme 


\section{Contents}

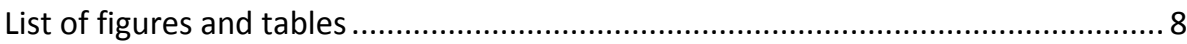

$1 \quad$ Implementation of regional sustainable development..........................11

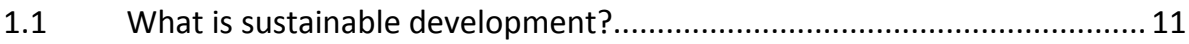

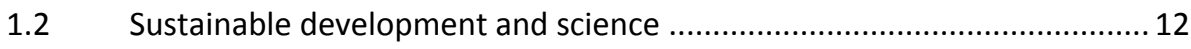

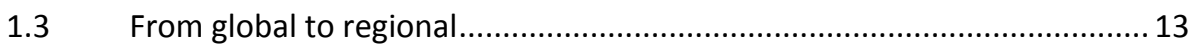

$1.4 \quad$ Governance and sustainable development ......................................... 15

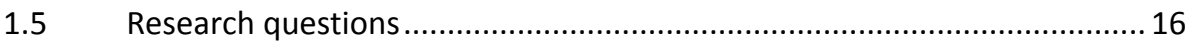

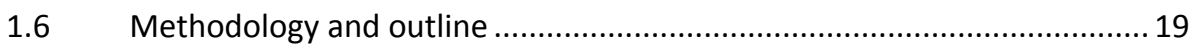

1.7 Quality assurance and policy relevance of this study.................................. 23

2 Governance for sustainable development: theoretical framework.........25

$2.1 \quad$ Governance for sustainable development.............................................. 25

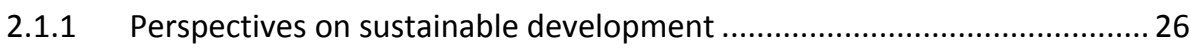

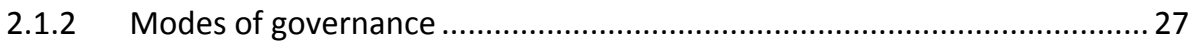

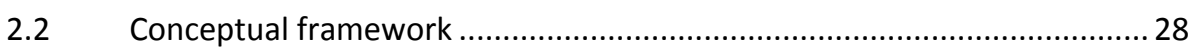

2.2.1 The ecological sustainability-hierarchical type ............................................ 30

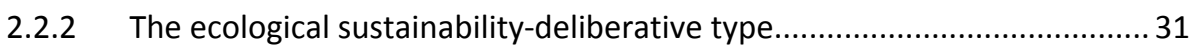

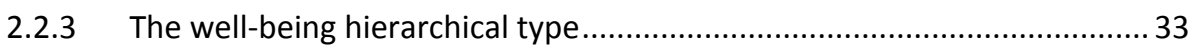

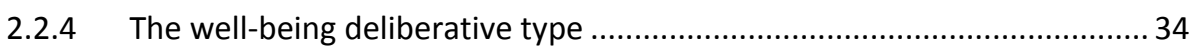

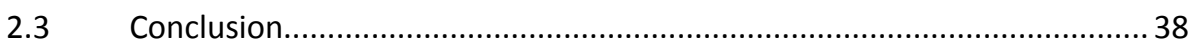

3 Sustainable development: from policy to principle ..............................39

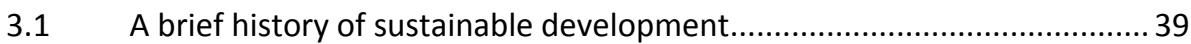

3.2 Current sustainable development policy analysed................................... 42

3.3 From policy to principle, and corresponding criteria............................... 48

3.3.1 Checklist for sustainable development.................................................... 50

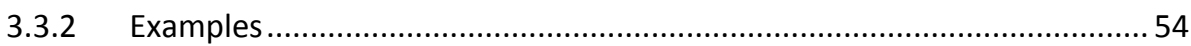

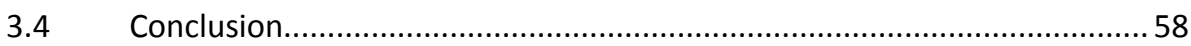

Annex 3.1: Analysis of three sustainable development strategies according to the framework for governance for sustainable development...................60

$4 \quad$ Sustainable development and the Limburg population ........................65

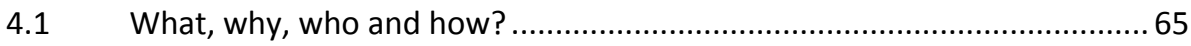

4.2 What do people think about sustainable development? ..........................67

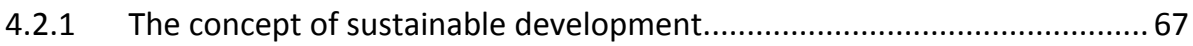

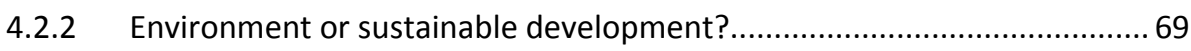

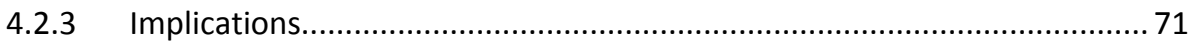

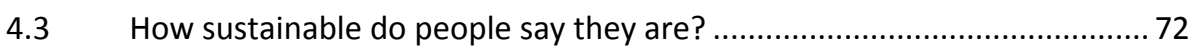

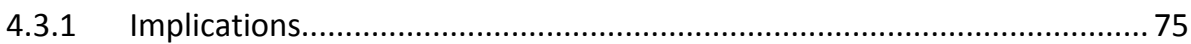


4.4 How sustainable do people act? ........................................................... 76

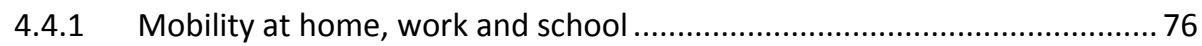

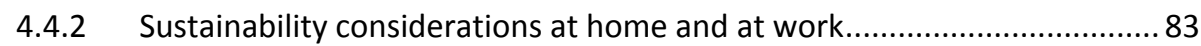

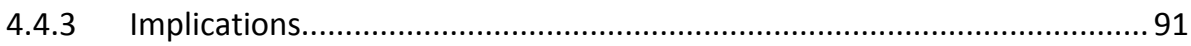

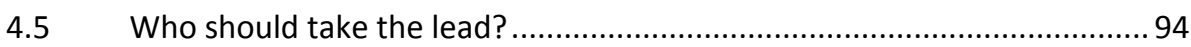

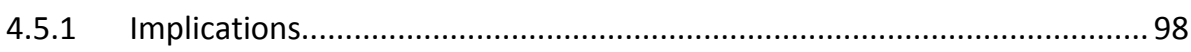

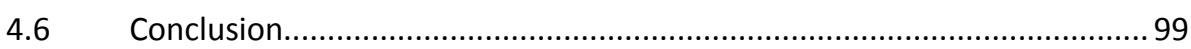

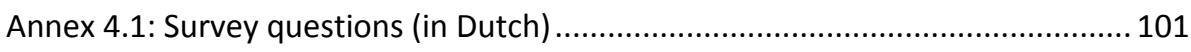

$5 \quad$ Implementing sustainable development: Lessons from two case studies in Limburg..................................................................115

Introduction ..................................................................................... 115

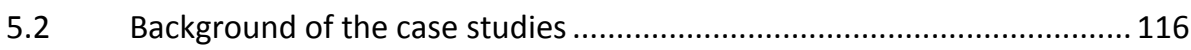

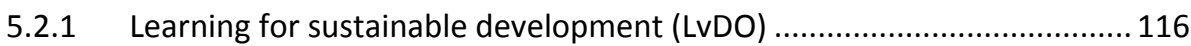

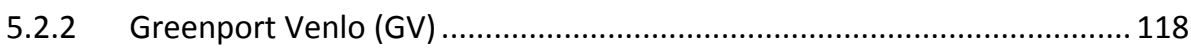

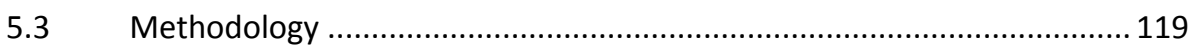

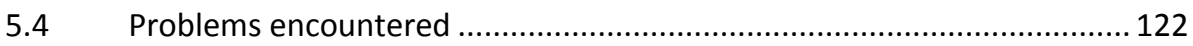

5.4.1 Analysis of problems that occurred in GV and LvDO .............................. 123

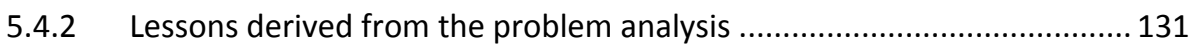

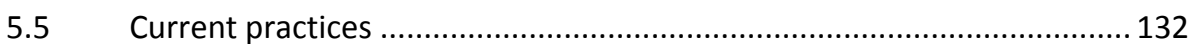

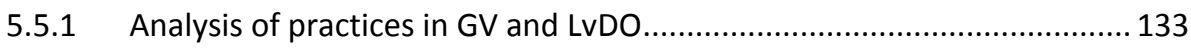

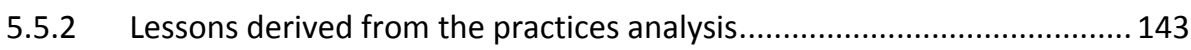

C.6 Conclusion........................................................................................... 144

ANNEX 5.1a: interview guideline Leren voor duurzame ontwikkeling (Dutch) ...... 147

ANNEX 5.1b: interview guideline Leren voor duurzame ontwikkeling (English) .... 150

ANNEX 5.2: Interview guideline Greenport Venlo ............................................. 153

6 An adaptive indicator framework for monitoring regional sustainable development .........................................................................157

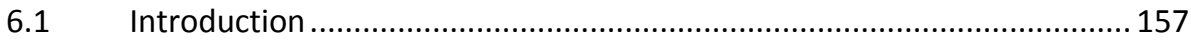

6.2 Measuring sustainable development: a normative issue ......................... 159

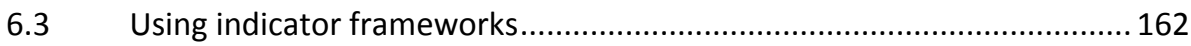

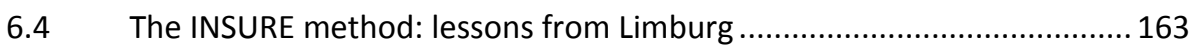

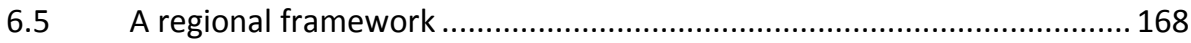

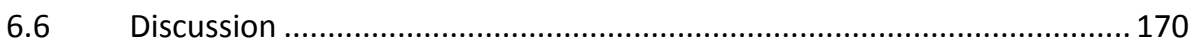

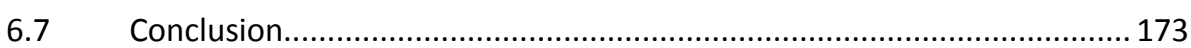

7 Comparing region-specific sustainability assessments through indicator systems: feasible or not? ..................................................175

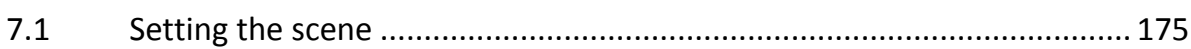

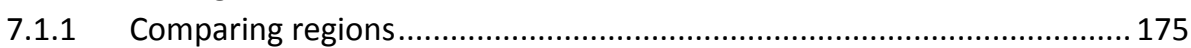

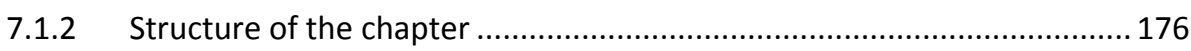




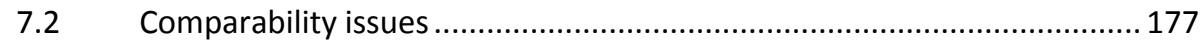

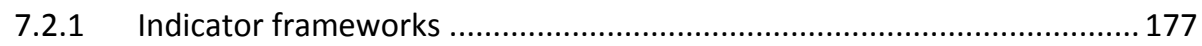

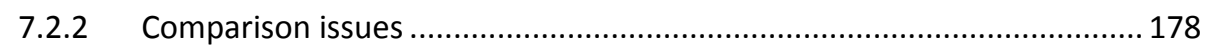

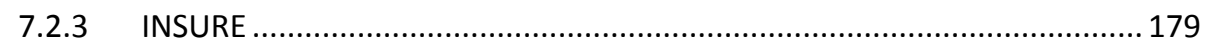

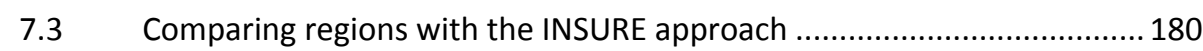

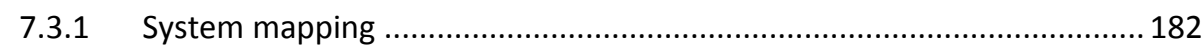

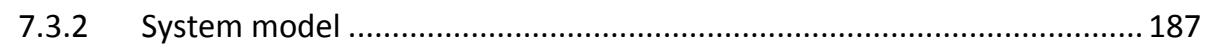

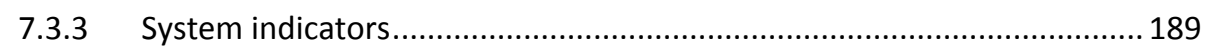

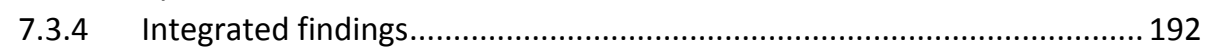

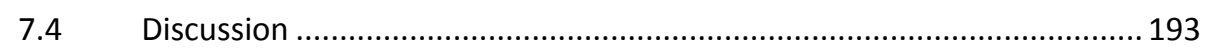

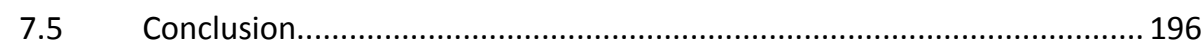

8 Conclusion, recommendations and reflection ....................................199

8.1 What barriers occur in current practices? .............................................. 200

8.1.1 Understanding sustainable development: complexity, vision, goals

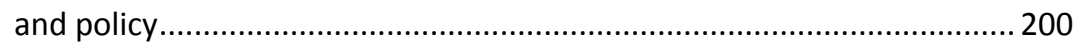

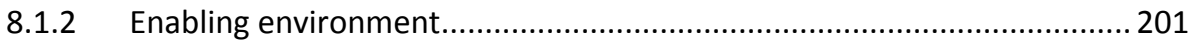

8.1.3 Sustainable development-consciousness ................................................... 202

8.2 Different perspectives on sustainable development, and different modes of governance, and the role they play in the barriers encountered ......................................................................................... 202

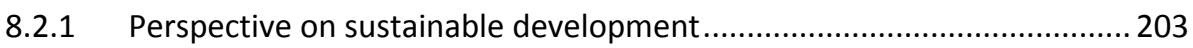

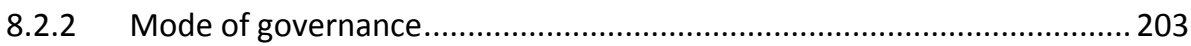

8.2.3 Expressions of governance for sustainable development ......................... 204

8.3 Some recommendations on how the specified barriers can be overcome.......................................................................................... 205

8.3.1 Understanding sustainable development: complexity, vision, goals

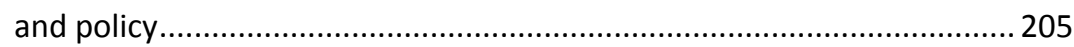

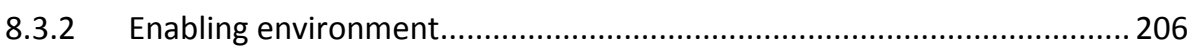

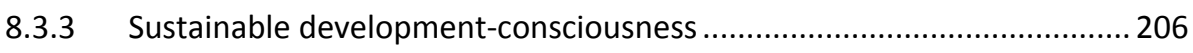

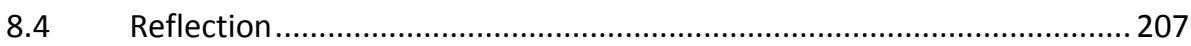

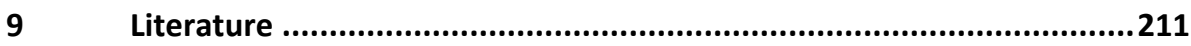

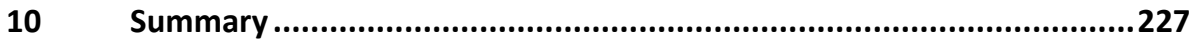

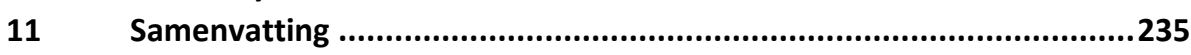

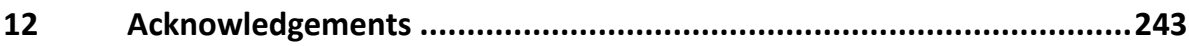

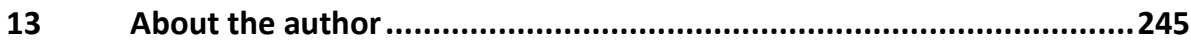




\section{List of figures and tables}

\section{List of Figures}

Figure 1.1: Policy operationalisation and scientific operationalisation

Figure 1.2: Graphical representation of the outline of this thesis

Figure 2.1: Conceptual framework of governance for sustainable development

Figure 3.1: Timeline of sustainable development policy and events at various scale levels

Figure 3.2: The theoretical framework of chapter 2 with the position of the SDS of the EU, $\mathrm{NL}$ and PL.

Figure 4.1: The importance of sustainable development

Figure 4.2: Topics related to sustainable development

Figure 4.3: A sustainable lifestyle

Figure 4.4: $\quad$ Becoming more sustainable $\quad 74$

$\begin{array}{ll}\text { Figure 4.5: } & \text { Sustainability of organisations } \\ \end{array}$

$\begin{array}{ll}\text { Figure 4.6: } & \text { Car use } \\ \end{array}$

\begin{tabular}{ll} 
Figure 4.7: & Means of transportation for commuting to work \\
\hline
\end{tabular}

\begin{tabular}{ll} 
Figure 4.8: & Reasons for choosing specific transport (work) \\
\hline
\end{tabular}

Figure 4.9: $\quad$ The most important means of transportation to work $\quad 79$

Figure 4.10: Means of transportation for commuting to school $\quad 80$

Figure 4.11: $\quad$ Reasons for choosing specific transport (school) 81

Figure 4.12: The most important means of transportation to school 81

Figure 4.13: Activities in households in the 6 months before survey $\quad 84$

Figure 4.14: The most important considerations for Leisure $\quad 85$

Figure 4.15: The most important considerations for Consumption 86

Figure 4.16: The most important considerations for Dwelling 87

Figure 4.17: The most important considerations for Production process and consumption 89

Figure 4.18: The most important considerations for using the office building 90

Figure 4.19: Important product information $\quad 91$

Figure 4.20: An unbalanced picture of sustainability 92

Figure 4.21: Who should take the lead? 95

Figure 4.22: The most important instruments for sustainable development 95

Figure 6.1: The role of policy and science in the various stages of monitoring sustainable 162 development

Figure 6.2: Combining the sustainability policy view as expressed in an indicator framework with the sustainability systemic view represented by a system map of the region showing relations between regional elements

Figure 6.3: The dashboard overview of sustainable development in Limburg for the EU-SDI framework.

Figure 7.1: The three tools interact and present different information that leads to a full assessment of each region.

Figure 7.2: $\quad$ Location of the four case studies 182

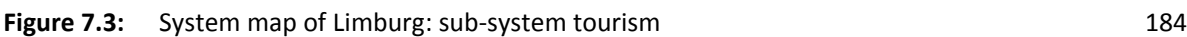

\begin{tabular}{lr} 
Figure 7.4: & Sustainability spectrum Limburg \\
\hline
\end{tabular}

Figure 7.5: $\quad$ Sustainability spectrum Lombardy 186 
Figure 7.6: Model results for the population prognosis 2000-2040.

Figure 7.7: An impression of the visual representation of the system indicators for the four case studies

\section{List of Tables}

Table 2.1: $\quad$ Different modes of governance compared 27

Table 2.2: Characteristics of various types of governance for sustainable development 36

Table 2.3: Expressions of governance for sustainable development, for various typologies 37

Table 3.1: $\quad$ Characteristics of governance for sustainable development. 44

Table 3.2: $\quad$ Expressions of governance for sustainable development 44

Table 3.3: Guiding principles of sustainable development in three strategies 51

Table 4.1: Comparing the scores for environment at the home situation with work and 70 school.

Table 4.2: Comparing the scores for sustainable development at the home situation with work and school.

Table 4.3: Comparing private and company sustainable behaviour

Table 4.4: $\quad$ Distance travelled correlated with type of transport (work) 80

Table 4.5: $\quad$ Distance travelled correlated with type of transport (school) 82

Table 4.6: $\quad$ Most important means of transport for work and school 82

Table 4.7: $\quad$ Top-3 reasons for choosing certain transport 83

Table 4.8: $\quad$ Government: importance and instruments 96

Table 4.9: $\quad$ Market: importance and instruments 96

Table 4.10: $\quad$ Society: importance and instruments $\quad 97$

Table 4.11: $\quad$ Research and education: importance and instruments 98

$\begin{array}{ll}\text { Table 4.12: } & \text { Overview of instruments per actor }\end{array}$

Table 5.1: Characterisation of interviewees by role and type of organisation 120

Table 7.1: $\quad$ The three tools compared 181

Table 7.2: $\quad$ Regional characteristics of the four case studies $\quad 182$

Table 7.3: $\quad$ The Limburg sustainability situation compared to potential 185

Table 7.4: $\quad$ The Lombardy sustainability situation compared to potential 186

Table 7.5: The theme "investment" that occurs in all four case studies is represented by 191 different entities in each region.

Table 7.6: Comparison challenges

\section{List of Boxes}

Box 3.1: Examples of the visions of EU, NL and Limburg

Box 5.1: First round of coding: code system defined by interview framework 120

Box 5.2: $\quad$ Second round of coding of problems and practices based on grounded theory 121

Box 5.3: $\quad$ Third round of coding grouping clusters in common themes 122 



\section{Implementation of regional sustainable development}

"There is undoubtedly a gap in implementation of sustainable development" said former UN Secretary-General Kofi Annan in 2001, almost ten years after the Rio Conference on Environment and Development (2001b). More recently, within the $\mathrm{EU}$, concern is expressed as well on the ongoing unsustainable trends and the limited results in curbing them (EU, 2009a; b; f). This thesis investigates the gap in implementation of sustainable development in the Province of Limburg, the Netherlands.

\subsection{What is sustainable development?}

Sustainable development means different things to different people, but the most frequently quoted definition is undoubtedly 'development that meets the needs of the present without compromising the ability of future generations to meet their own needs' (World Commission on Environment and Development, 1987). Sustainable development is, however, a complex concept, dealing with different temporal and spatial scales and with multiple stakeholders (Martens, 2006). It indicates a societal process of changes whereby the development goal is not clearly outlined and is subject to changes throughout the process. In order to foster processes of sustainable development we need to use a pluralistic approach that can deal with multiple actors and multiple levels, and that is able to help create a shared vision on sustainable development and to resolve trade-offs (Zeijl-Rozema van et al., 2008). The concept of sustainable development requires that we see the planet and our world as a system. A system that connects space ('here and there') and a system that connects time ('now and later') (IISD, 2007). A central feature of sustainable development is that we adopt an integrated vision.

Simultaneously, sustainable development can be seen as a political or normative act, rather than a scientific concept. Sustainable development is after all about the quality of life we desire now and in future. An equity element is important as well: other people elsewhere in time or space also have the right to quality of life. Sustainable development is about making choices and trade-offs visible within the context of our desired future. The desired future will be different, from place to place, and from person to person. Hence, many views on sustainable development exist. The power of the concept is that it brings the differences in world views and in contradictions in current behaviour to the surface and provides a playing field for the debate (Lafferty, 2004; Robinson, 2004). 


\subsection{Sustainable development and science}

The idea of sustainable development -meeting fundamental human needs while preserving the life-support systems of planet Earth- emerged both from science and the environmental movement in the 70s and 80 s of last century (Kates et al., 2001; Lafferty, 2004). Since then a lot was done in the field, sometimes without even naming it sustainable development (e.g. improved cooking stoves, basic sanitation), but a lot still remains to be done (Cash et al., 2003; Clark and Dickson, 2003). Clark and Dickson (2003) observe that after the 1992 United Nations Conference on Environment and Development (UNCED) in Rio de Janeiro the discussion of how science and technology could contribute more effectively to sustainable development intensified. After the World Summit on Sustainable Development (WSSD) in Johannesburg in 2002 the strongest message for science was that the research community needed to complement its traditional role of identifying problems of sustainable development with a greater willingness to join with other communities to work on practical solutions to these problems (Clark and Dickson, 2003).

In science for sustainable development we see a variety of "new" approaches that are used to deal with sustainable development, such as post-normal science, mode-2 science, sustainability science, action research, integrated assessment, and more. Recurrent issues that science for sustainable development is dealing with are (Amelung 2006; Brugge 2009; Dijk 2010; Grosskurth 2008; Huynen 2008; Lamers 2009; Loorbach 2007; Moreno 2010; Valkering 2009):

Type of problem

complex, societal, decision stakes high, disputed values, systemic uncertainty high

Knowledge production: inter-, transdisciplinary ${ }^{1}$

Goal:

contribute to decision-making by improved problem understanding, structuring complexity and bringing about societal change

Challenges:

dealing with long-term developments and short term actions, dealing with spatial scale levels, dealing with uncertainty and risk, co-production of knowledge, combining qualitative and quantitative approaches, integrating knowledge, perspectives and interests, structuring complexity, quality assurance of results

\footnotetext{
${ }^{1}$ Transdisciplinarity is integrating tacit and lay knowledge with scientific knowledge cf.(Loorbach 2007). This is different from multidisciplinarity: combining knowledge from different scientific disciplines, and interdisciplinarity: integrating knowledge from different scientific disciplines using a shared conceptual framework.
} 
The purpose of science for sustainable development is to support decision-making (Clark and Dickson, 2003). In that sense it is important to recognise the variety of roles and interactions scientists can have with decision-makers. Pielke (2007) suggests four ideal types of experts interacting with decision-makers, that have an increasing amount of interaction between expert and decision-maker:

The first two types serve as information resources:

- The pure scientist, who has no interaction with the decision-maker and focuses on facts;

- The science arbiter who answers the specific question posed by the decisionmaker, but does not enter in dialogue;

The next two types favour an explicit engagement of decision alternatives:

- The issue advocate who interacts with the decision-maker by reducing the scope of options, by pointing at what the decision-maker ought to do. This type focuses on the implications of research for a particular political agenda;

- The honest broker who interacts with the decision-maker by clarifying the scope of choice available to the decision-maker, each with their range of possible consequences.

However, Pielke also acknowledges that the interaction between experts and decision-makers depends on the context and can (and usually will) be complicated. Important is his message that we have choices in how experts relate to decisionmakers. These choices determine the usefulness, the legitimacy and authority of the expertise.

We should not only be aware of the different roles of science, but also acknowledge that science has its limits. Science cannot tell us what to do. Pielke (2007) makes clear that deciding what to do occurs through a political process of bargaining, negotiation and compromise. What science can do in the face of uncertainty and contested values, in other words, in a field such as sustainable development, is to contribute to the development of new and innovative policy options that might allow for compromise between opposing parties. One of the important roles of science in policy-making is to inform expectations about choices and their possible outcomes. Questions of desirability of the outcomes and acceptability of risks must, however, be handled through political processes (Pielke Jr., 2007).

\subsection{From global to regional}

Sustainable development started off small, but soon became an issue at the global policy level. Lafferty (2004) dubs the UNCED process leading towards the Rio Declaration and Agenda 21 (A21) in 1992 as an "outside-in programme" meaning that it transpired largely outside the realm of normal domestic politics. The number of actors involved in designing Agenda 21 was small and very professional, draft documents were known to only a limited number of people and goals were formu- 
lated in a highly abstract manner. However, A21 requested the involvement of all sorts of major groups, who were at the time not even aware of their responsibilities. The first task of governments was then to translate the results of the Rioconference to their citizens and major groups, with the ultimate idea that sustainable development would be implemented at the sub-national level (cf. UN, 1992; 2002).

The sub-national level which is defined in this thesis as the regional level is thought to have, in terms of geographic scale, an optimal size for successfully implementing sustainable development: small enough to be concrete and of direct interest to residents and large enough to possess critical mass for collective action and creative solutions (UN, 1992; Zilahy and Huisingh, 2009). The UN (cf. UN, 1992; UN, 2001a; 2002) as well as the EU (cf. Committee of the Regions, 2005; 2007; EU, 2007; 2008a) repeatedly affirm the importance of local and regional authorities in achieving sustainable development. A region should be seen in this thesis as an area smaller than a nation that has an identity demarcated by boundaries (an administrative entity) or identified by relatively homogeneous economic, social, or landscape characteristics. In this sense, a region can cross borders (e.g., the Euroregion Meuse-Rhine includes parts of Belgian, Dutch and German provinces and is an area with a shared history and similar economic interests). Graymore et al. (2008) contend that the regional level provides the greatest opportunity for local governments to work together with their constituent communities toward sustainable development.

Although implementation of sustainable development policy is expected to happen at the regional level, this is not the case. At EU level, interlinkages between the national and regional policy level are not well developed and national strategies for sustainable development are "rather weak policies" which have only a "limited capacity to guide sustainable development governance" (Research Institute for Managing Sustainability (RIMAS), 2009). What we see worldwide since the Rio Conference in 1992 is a fragmented approach towards sustainable development, no significant changes in consumption and production patterns, a lack of mutually coherent policies and approaches in the areas of finance, trade, investment, technology and sustainable development, and a lack of resources for implementing Agenda 21 (UN, 2001b). The EU's 2009 Presidency report reviewing the EU Sustainable Development Strategy (SDS) also expresses concern about the ongoing unsustainable trends and the limited results in curbing them (EU, 2009a). This is confirmed by the European Council and a request is made for reinforcing "governance, including implementation, monitoring and follow-up mechanisms" (EU, 2009b). Also Eurostat mentions in its 2009 monitoring report of the EU SDS that "little progress seems to have been made since the 2007 Monitoring Report, confirming that 
more efforts are necessary in the European Union to get on the pathway to sustainable development" (EU, 2009f). A question we should ask is, what makes realising sustainable development so difficult?

\subsection{Governance and sustainable development}

Sustainable development is a collective interest, just like other common interests such as sanitary and drinking water facilities, health care, education, and public transportation. However, sustainable development is also different: it is complex, (cf. Zeijl-Rozema van et al., 2008) containing multi-actor, multi-sector and multilevel problems and, although there is a sense of urgency, action is lagging behind. Consequences of unsustainable development often only become visible in the long run or elsewhere, whereas a disruption of, for instance, water supply has immediate consequences. Sustainable development receives support at government level and in society, but a general notion of urgency leading to action seems to be missing. Individual benefits that are clear in sanitation or health are not so clear in sustainable development. In such a case governance is needed to shape the societal process of change towards sustainable development.

Wicked problems, social complexity and weak institutionalization are elements of sustainable development that undermine the rationale of 'traditional' governing with governments as institutions with hierarchical power, and support the idea of governance as a shared responsibility of representatives from the state, the market and civil society dealing with societal problems. According to Kemp et al (2005) better governance is a prerequisite for taking steps towards sustainability. Governance can be seen as a collection of rules, stakeholder involvement and processes to realize a common goal (Kemp and Martens, 2007).

To understand better what governance is about, we refer here to the four dimensions of governance by Meuleman and In 't Veld (2009): actors, institutions, instruments and processes that, together, help society to achieve its common interest.

- Actors are those who participate in the process. In governance we often talk about actors belonging to the sphere of State, Market and Civil Society (Glasbergen and Driessen, 2002), or in a different model actors that belong to Government, Education, Research, Business and Environment, meaning community (Termeer and Kranendonk, 2008);

- Institutions are collectively accepted structures or systems of rules that give a certain status to something or someone. For instance, the status of a 20 eurobill is that it has a certain value because it belongs to the collectively accepted structure of money. Institutions can be of a formal or informal character. However, Meuleman and In 't Veld mainly refer to formal institutions such as government and research institutions. An institution carries obligations, rights, and 
responsibilities (Meuleman and in 't Veld, 2009; Searle, 2005; van Bueren and ten Heuvelhof, 2005);

- Instruments help to achieve the goal. They can be instruments that help processes, or focus on the goal. Think of legislation, standards, manuals, monitoring, enforcement, participation, information (Huppes and Simonis, 2008);

- Processes are about how things are organised. Think of decision making, negotiation, political process, democratic process (cf. Buuren, 2009; Grundmann, 2009; Keil, 2006).

Governance for sustainable development has to deal with uncertainty, a diffuse responsibility of impacts, complexity at systemic level and among actors and sectors, large temporal and spatial scales, and possible irreversibility of processes. Therefore, it requires dynamic problem solving, conflict resolution, integration of information, involvement of the different actors at many levels, coordination across policy areas and vision, goals, benefits and concreteness (Kemp et al., 2005; van den Hove, 2000). All in all, this is not an easy task.

\subsection{Research questions}

The Province of Limburg, the southernmost province of the Netherlands, struggles with implementing sustainable development. Although sustainable development is present in several provincial policy documents (Province of Limburg, 2001; 2005a; 2007b) there is a worry that this is not enough for realising sustainable development in the province. In order to understand this problem we need to look at a variety of issues: the nature of sustainable development, the implementation gap and governance as a necessity for realising sustainable development.

For our analysis we need to clarify the concepts of operationalisation as it can mean various things. First of all we need to clarify the subject of operationalisation. Operationalisation for policy-makers refers to a certain stage in the policy cycle when a policy document is translated into actions to achieve the policy goals. Indices can emerge as a policy and planning tool (Pearsall and Pierce, 2010; RIVM, 1999), certain operational structures might be formed such as steering groups or panels (Hanney et al., 2001), resources need to be allocated and sometimes legislation needs to be changed or developed (Sydnes, 2001). Operationalisation in policy terms is sometimes almost synonymous with implementation (e.g.Hanney et al., 2001; ILO, 2004).

In scientific terms, however, operationalisation means something different. It means to make a construct measurable. The exact meaning depends on whether the researcher follows a quantitative deductive approach or a qualitative inductive one. In the former, operationalisation comes after conceptualisation and leads to an operational definition and certain methods to measure the various criteria (e.g. 
survey, questionnaire, indicators). Data collection is meant to test a hypothesis. In qualitative research, operationalisation describes the process of how data were collected and different steps in thought processes. Conceptualisation follows after data collection and operationalisation (Lawrence Neuman, 2003).

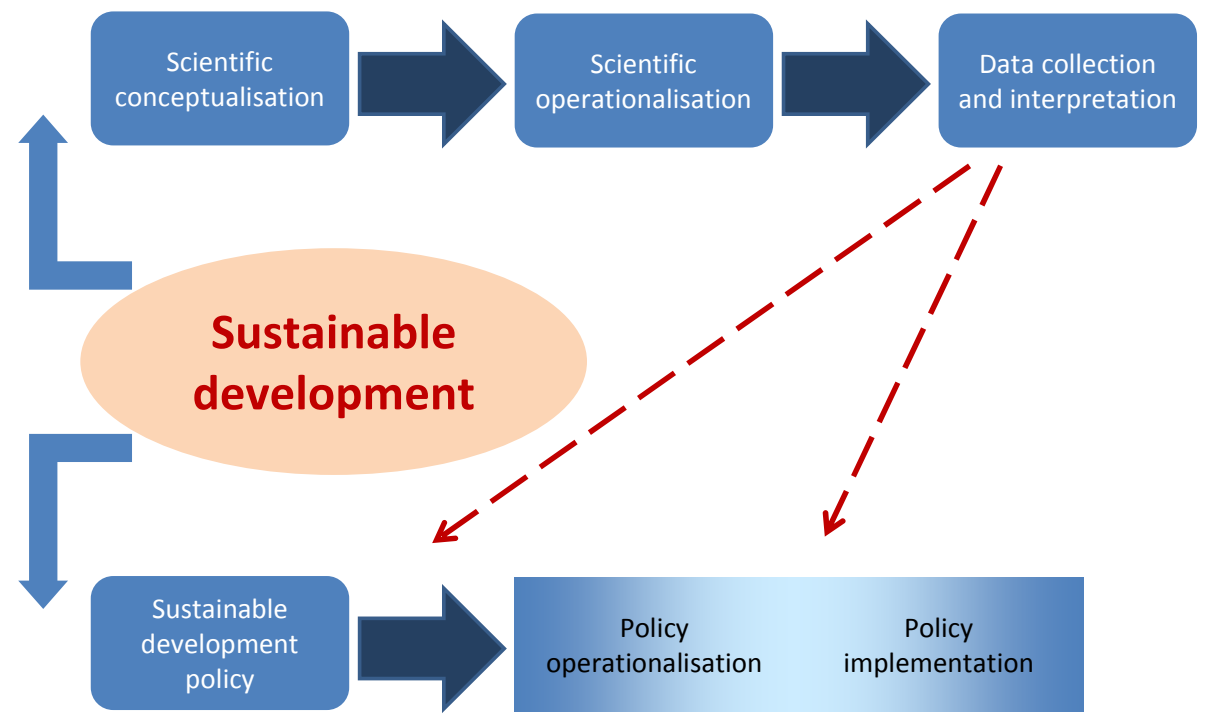

Figure 1.1: Policy operationalisation and scientific operationalisation

In scholarly papers many examples of the scientific interpretation of operationalisation can be found, even when research on policy operationalisation or other policy processes is done (Anderson, 2010; Kondyli, 2010; Lütkenhorst, 1982; Ozkaynak et al., 2004; Runhaar, 2009; Ziegler, 2009). In that case, scientific operationalisation is often meant to show the opportunities and limits of a certain policy approach, although without means to enforce the adoption of a certain approach, which you would find in political operationalisation (Ziegler, 2009). This means that scientific operationalisation of a policy related construct can play a role in the policy operationalisation by providing insights in problems or by providing indicators for measurement of policy progress. See figure 1.1.

This thesis refers to operationalising regional sustainable development in a scientific understanding of sustainable development. It does not look at how policy can be operationalised, but it aims at making regional sustainable development more tangible in order to provide useful information for policy-makers to operationalise and, finally, implement sustainable development policy. We do this by investigating current sustainable development practices and the problems associated with them that represent barriers to implementation of sustainable development. Burch states that a better understanding of barriers provides a valuable element for fu- 
ture policy design and policy evaluation. Termeer (Termeer, 2009) applies her insights into barriers to new modes of horizontal governance to develop and perform interventions to break through these barriers. In the following chapters policy will be investigated because it sets the context for action. Citizens and practitioners are investigated because they are the ones affected by policies and they need to realise them. Monitoring is addressed because it provides information on the progress made.

One issue mentioned before is that different views on sustainable development exist and that different views will result in different trajectories towards implementation of sustainable development, which is recognised in this thesis. Different modes of governance exist with which to shape sustainable development. Their role in sustainable development is recognised and explored in this thesis. Because of the importance of the region in operationalising sustainable development, and because of the interest of the Province of Limburg in finding better ways to implement its sustainable development policies, this thesis addresses the regional level. Thus, the research question reads:

What are the barriers to implementation of sustainable development in current practices in Limburg, taking into account different perspectives on sustainable development and different modes of governance; and how can they be overcome?

Implementation in this thesis refers to operationalisation and implementation of policy and plans on sustainable development, or, in terms of figure 1.1: policy operationalisation and policy implementation. No specific distinction between the two is made because the boundary between them is often diffuse. When the term operationalisation is used, it refers to the scientific interpretation of operationalisation: making a construct measurable and tangible.

Related sub-questions that are addressed in this thesis are:

- What role do different perspectives on sustainable development and different modes of governance play in current sustainable development practices?

- What barriers to realising sustainable development exist in sustainable development strategies (SDS)?

- What barriers exist in the current understanding of, and action towards, sustainable development of the Limburg population?

- What barriers to realising sustainable development exist in current sustainable development projects in Limburg, and what role do the different modes of governance play?

- How can sustainable development be monitored in an integrated way, and what barriers occur? 


\subsection{Methodology and outline}

Under the umbrella title of "governance for sustainable development" the Province decided to fund a research project to provide insights in the matter. This project includes a part of this thesis (chapters 1-5, 8). Chapters 6 and 7 are based on work done for an EU funded project. That resulted in an instrument for integrated monitoring of sustainable development, that was used in the 2007 and 2009 Limburg monitor, a biannual monitoring of the province. Furthermore, a policy summary of the findings, based on this thesis, will be made with recommendations for realising sustainable development. Finally, a symposium with a presentation of the results coupled with workshops to overcome the barriers will be organised.

It should be noted that the underlying thesis does not include all processes that have been part of the project. For instance, the process of interaction between researcher and provincial administration has not been documented, although findings on the roles of experts and policy makers can be found in chapter 7. Nor has the effect of the reorganisation of the administration during the research been taken into account.

The following chapters explore the sub-questions and contribute to answering the research question. Below is a brief outline of each chapter and a summary of the methods used (see Figure 1.2). Each chapter describes the specific methodology used in more detail. Chapter 2 presents the theoretical framework used for analyses of empirical data in chapters 3, 4 and 5. Chapters 3-7 present current practices and their barriers. Each of these chapters has a different angle for investigating the barriers to implementation of sustainable development: a policy perspective in chapter 3, a citizen's perspective in chapter 4, a practitioner's perspective in chapter 5 and a monitoring perspective in chapters 6 and 7 .

Chapter 2 is devoted to a theoretical framework of governance for sustainable development. Different modes of governance and different perspectives of sustainable development will lead to different constellations of actors, processes, instruments and institutions involved in realising sustainable development. Without making explicit what type of governance for sustainable development is pursued, miscommunication between stakeholders and mismatches of the approach with the instruments used could be the result, thus hampering progress in implementing sustainable development.

The reason for developing this framework was to reduce the complexity of governance for sustainable development as this is an important line of analysis in this thesis. The framework serves as a basis for the analyses in chapters 3 and 5 and the final synthesis in chapter 8 . 
The framework was based on extensive literature research that helped to establish context, to obtain material for verification with empirical data in later chapters and for combining knowledge to gain new insights.

Chapter 1: What are the barriers to policy implementation of sustainable development in current practices in Limburg, taking into account different perspectives on sustainable development and different modes of governance; and how can these barriers be overcome?

\section{Practices studied to investigate barriers in Limburg}

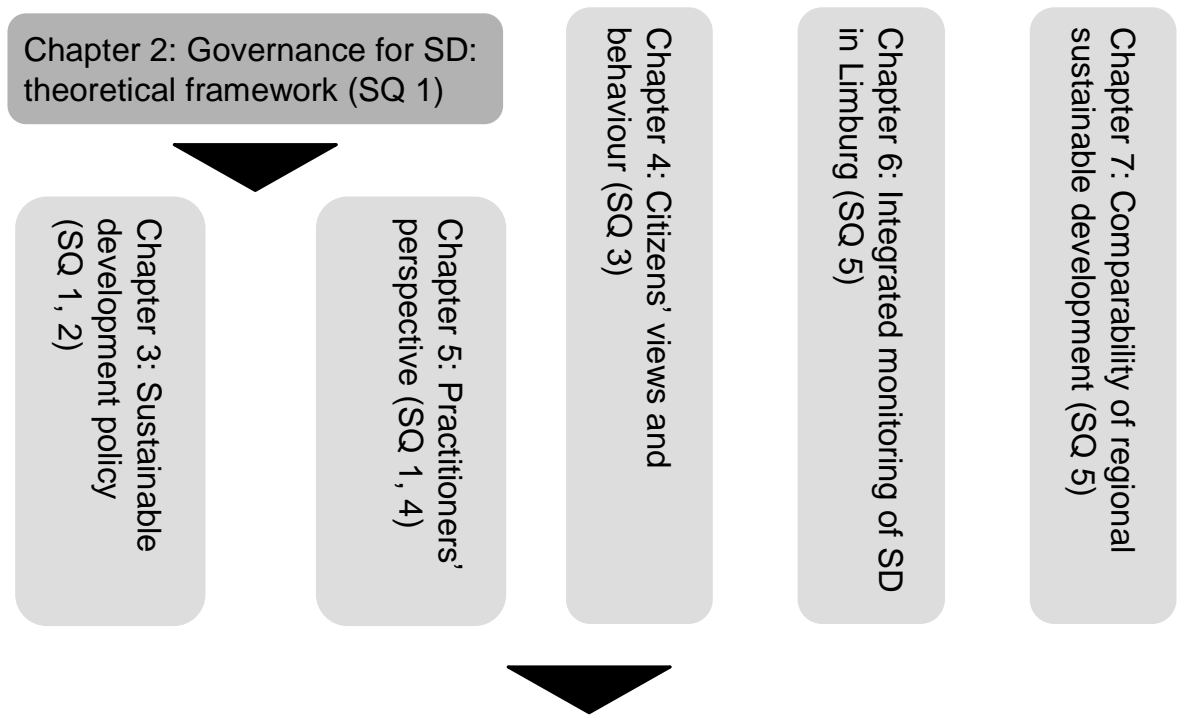

Chapter 8: Conclusion, recommendations and reflection

Figure 1.2: Graphical representation of the outline of this thesis (SQ refers to the related sub-question of section 1.5)

Chapter 3 explores the policy context of sustainable development, dealing with the international, national and provincial levels. It investigates the strong and weak points of these policies, and it poses the question whether sustainable development should be placed in a special niche with its specific policy, or whether it would be better to use sustainable development as a guiding and overarching principle for all policy. 
Policy documents and scientific literature were studied to establish context, to combine insights from policy documents with findings in literature, and to combine knowledge to gain new insights.

Chapter 4 addresses society's understanding of sustainable development and behaving in a sustainable way. It is assumed that one reason why implementation fails is because people are unfamiliar with the concept, the concept is too abstract and is not well understood. However, it is also assumed that people do take actions that fall within the context of sustainable development without being called that. Therefore, a representative sample of the Limburg population was surveyed by means of an internet survey with a pre-selected pool of respondents. More than 900 people responded. Statistical analysis was carried out on the results. Information was obtained on the population's level of knowledge of sustainable development, the extent to which behaviour is sustainable and the population's opinion about sustainable development, e.g. who should take the lead, how important it is. Because the sample was large enough, and the population of the survey is representative for the provincial population, results can be extrapolated at least for the region.

Chapter 5 has a practitioners' focus on sustainable development. It investigates two case studies in Limburg: 'Greenport Venlo' and the programme 'Learning for Sustainable Development' in Limburg. 'Greenport Venlo' is a voluntary network organisation that aims at regional development, involving a multitude of stakeholders. 'Learning for Sustainable Development' is a government subsidised programme to stimulate more sustainable development in the region by giving grants to educational projects.

Nine semi-structured interviews were carried out with process managers in two different governance configurations: "Greenport Venlo" and "Learning for sustainable development in Limburg". The aim was to find out more about the governance structures, the perspective on sustainable development, the problems encountered and the approach followed. A text analysis of the interviews was carried out with an adjusted version of grounded theory. The goal was to get insights into practices and problems of sustainable development in different governance settings with concrete material. The information so-obtained was rich in detail, based on practical experience and contained personal viewpoints and feelings.

The interview results were enriched with a literature review to establish context, and to obtain material for verification with empirical data. It is difficult to extrapolate general conclusions from such specific cases. However, the information gives insights about the process towards sustainable development in the region, and about possible areas for concern that need further exploration 
Chapter 6 discusses the challenges and the lessons learned in integrated monitoring of regional sustainable development. An adaptive indicator framework for integrated monitoring of sustainable development was developed for Limburg, which was then used for the Limburg Monitor. During the project it became increasingly clear that indicators are not only more meaningful when viewed within the context of the whole system, but also that science and policy play different, but complementary, roles.

Chapter 7 also builds on the integrated monitoring of sustainable development, but focuses on the question of comparing different regions. Comparability of sustainable development between different regions is not a matter of rigid comparison of indicator by indicator. It should take into account regional specifics. The resulting shift from strong to weaker comparability should not be seen as lessening the quality of the assessment and decreasing comparability. Rather than focusing on individual indicators within frameworks that do not permit inclusion of regional developments, this approach allows to look at the broader picture of regional dynamics. It reveals specific regional weaknesses that need attention, and possible areas for building alliances between regions, thus creating a more sustainable Europe.

Chapters 6 and 7 made use of a qualitative systems analysis for monitoring and comparing regional sustainable development

There are three reasons for conducting a qualitative systems analysis (QSA):

- To obtain an integrated vision of Limburg, e.g. to establish context

- To find the most important driving forces for Limburg, in order to identify indicators, The most important attributes and their indicators provide an indication of the status of the province in terms of sustainable development

- To place the current system in perspective with an upper and lower boundary of its sustainability potential

Information for the QSA was obtained though literature research of policy documents and scientific literature to establish context, to combine insights from policy documents with findings in literature, and to combine knowledge to gain new insights. Furthermore, an expert group was consulted who modelled their vision of the province based on their experience and insights.

Finally, chapter 8 summarises the partial conclusions of this thesis and comes back to the question of how to overcome the barriers towards regional sustainable development. 


\subsection{Quality assurance and policy relevance of this study}

This thesis aims to be policy relevant. For this to be true, some quality assurance is needed. In research, professional practice or industrial development, quality is assured respectively by peer review, professional associations or the market. For the new type of problems such as sustainable development with high decision stakes and contested values and uncertainties, quality also depends on open dialogue between all those affected, or an "extended peer community" (Ravetz, 1999).

This study includes several peer reviewed papers, and different methods for triangulation. It is assumed that similar results from different methods give a greater measure of quality. The survey results of chapter 4 were analysed with nondisputed statistical methods, which seems to make a consensus conference or other involvement of the extended peer community regarding the results rather unnecessary. The interviews were checked by the interviewees. However, in general the usefulness of the results will be improved if the provincial administration shares the findings with the market and society in order to decide on a mutually acceptable road towards the future.

Another aspect of quality is how knowledge has been integrated to come to a conclusion. The integration of knowledge in this thesis is done to some extent with the help of the theoretical framework developed in chapter 2 . This framework identifies important concepts (governance, sustainable development) and offers criteria for analysis, thus permitting to talk about different knowledge in similar terms. But more research in proper routes for integrating knowledge ought to be done.

The policy-relevance of this thesis is further ensured by the other products related to the research project: An instrument for integrated monitoring of sustainable development was set up and is being used. A policy summary of the main barriers and possible solutions and recommendations is produced, and a symposium with a presentation of the results coupled with workshops to overcome the barriers is organised. 



\section{Governance for sustainable development: theoretical framework}

Based on: Zeijl-Rozema van, A., Cörvers, R., Kemp, R., Martens, P., 2008. Governance for sustainable development: a framework. Sustainable Development 16: 410 421.

\subsection{Governance for sustainable development}

This chapter explores how two complex concepts, governance and sustainable development can be linked in order to obtain a better understanding of their interactions and their implications for realising sustainable development. Sustainable development will not happen by itself, because of some characteristics that prevent it from happening spontaneously. In terms of the content, most sustainability issues can be seen as wicked problems (ill-defined, unstructured), and require a change in thinking, tools and methods that are useful only for simpler ('tame') problems. In terms of the process of involving a plurality of parties, most sustainability policies and projects have to deal with social complexity in the sense of the number and diversity of parties involved, and their relations, interactions, beliefs, interests and resources. In terms of the context or institutional setting, most sustainability initiatives are confronted by weak institutionalization, and require structural changes in the dominant institutions.

Wicked problems, social complexity and weak institutionalization undermine the rationale of 'traditional' governing with governments as institutions with hierarchical power. We need governance as a means to steer the process, where the idea of governance is a collection of rules, stakeholder involvement and processes to realise a common goal (Kemp and Martens, 2007), with a shared responsibility of representatives from the state, the market and civil society dealing with societal problems.

This chapter aims at a better understanding of how the combination of various perspectives on sustainable development and different modes of governance creates different strategies for implementation.

Without making explicit what type of governance for sustainable development is pursued, miscommunication between stakeholders and mismatches of the approach with the instruments used could be the result, thus hampering progress in implementing sustainable development.

Therefore, let us first have a closer look at various perspectives on sustainable development and different modes of governance. 


\subsubsection{Perspectives on sustainable development}

Sustainable development is not a single, well defined concept and various positions and perspectives exist. Hueting and Reijnders (2004) argue that sustainability is defined by ecological boundaries that can be scientifically determined. McCool and Stankey (2004), however, stress that the question of what is to be sustained, is a societal one and therefore at once both a technical as well as a normative decision. Gibson (2001) points to the normativity of the sustainable development perspective because it includes society and societal development. Brand and Karvonen (2007) argue that sustainability is also locally specific and more a matter of local interpretation than of the setting of objective or universal goals. The UK government relates sustainable development to quality of life and well-being (DEFRA, 2005). In Bhutan the development strategy is guided by the philosophy of 'Gross National Happiness' based on sustainable and equitable economic growth, ecological and cultural preservation and good governance (Rinzin et al., 2007).

From this short overview we learn that there are different views on sustainable development. Whichever view is propagated, it entails a normative choice. A choice either for giving priority to ecological concerns or to societal concerns. Besides, it is often understood that there has been an evolution of the concept over time from the early focus on the environmental dimension towards the current understanding that sustainable development is a process that integrates economical, environmental and societal objectives (UNDESA, 2001). Without making judgement, we place on one end of the continuum sustainable development as a concept related to ecological limits for growth that is based on scientific evidence and that can be objectified by using science-based criteria and indicators. On the other end sustainable development is seen as a normative and fuzzy concept related to well-being and quality of life, that is context dependent and a result of societal preferences, and that allows for many divergent opinions to co-exist. In our discussion we therefore distinguish between an ecological sustainability perspective and a well-being perspective on sustainable development (see the next section for more details). However, we acknowledge the many mixed forms that currently exist. When we think of the UK's sustainable development strategy "Securing the Future" (DEFRA, 2005) the definition used" ${ }^{2}$ has a strong emphasis on quality of life. At the same time the Strategy states "This (pursuing the goal of sustainable development, AvZR) will be done in ways that protect and enhance the physical and natural environment, and use resources and energy as efficiently as possible.", which is a clear indication of ecological sustainability.

\footnotetext{
${ }^{2}$ The goal of sustainable development is to enable all people throughout the world to satisfy their basic needs and to enjoy a better quality of life, without compromisng the quality of life for future generations
} 


\subsubsection{Modes of governance}

Different views on sustainable development may lead to different governance approaches. The term governance represents the notion of steering, and can be seen as a shared responsibility of representatives from the state, the market and civil society dealing with societal problems (Glasbergen and Driessen, 2002). When talking about governance we generally accept that the state no longer has the necessary authority or means to produce a (political) position that adequately represents the general or collective interest (Lamy and Laidi, 2002). Various scholars have made a classification of different modes of governance (table 2.1). Kooiman (2003) distinguishes between hierarchical, co- and self-governance, ranging from dominance of one actor (often the state) over other actors, to social-political autonomy of all actors. In the NewGov project researchers see different modes of governance depending on the level of state or public actor involvement. This can range from hierarchical to non-hierarchical coordination (Börzel, 2006; Börzel et al., 2005), from public authority towards societal autonomy (Treib et al., 2005) or from hierarchy towards heterarchy (Smismans, 2006). At all levels, from local to transnational, we see a movement away from 'traditional' governing with governments as institutions with hierarchical power, towards governance as a shared responsibility of public and private actors. Swyngedouw (2005) calls this governance-beyond-thestate and defines it as horizontal networks of private (market), civil society (usually NGO's) and state actors. Finally, governance-without-the-state is also possible. This is the case in fragile or weak states where governance arises because people have common interests and they cannot rely on the state to help them.

Table 2.1: Different modes of governance compared

\begin{tabular}{|l|lr|}
\hline Author & Increasing societal autonomy & Co-governance \\
\hline Kooiman & Hierarchical Self-governance & Governance at a distance \\
\hline $\begin{array}{l}\text { Hufen \& } \\
\text { Koppenjan }\end{array}$ & Rational Values Policy networks & Autonomy of private actors \\
\hline $\begin{array}{l}\text { Börzel, Börzel } \\
\text { et al. }\end{array}$ & $\begin{array}{l}\text { Autonomy of public actors } \\
\text { Hierarchical }\end{array}$ & Societal autonomy \\
\hline Treib et al. & Public authority & Heterarchy \\
\hline Smismans & Hierarchy & Governance-beyond-the-state \\
\hline Swyngedouw & Hierarchical government & \\
\hline
\end{tabular}

From this short overview we conclude that different modes of governance are possible and are seen to exist on a continuum (Börzel et al., 2005; Kooiman, 2003; Treib et al., 2005). We would, therefore, like to propose two modes of governance as the points between which most modes of governance for sustainable develop- 
ment can be captured: hierarchical governance -which is not dissimilar to traditional governing- and deliberative governance in which societal actors shape societal goals through dialogue and social learning. We will explain these in more detail below.

\subsection{Conceptual framework}

In the following we first characterise the perspectives on sustainable development and modes of governance that were identified in the previous paragraph. Then we combine the perspectives and modes into a conceptual framework for analysing governance for sustainable development. Subsequently, we discuss the views of several scholars on the matter, and place them in the framework. Finally, we provide some examples for each combination.

In the previous paragraph we distinguish between an ecological sustainability perspective on sustainable development and a well-being perspective. Within the ecological sustainability perspective sustainable development is seen as an issue of development within the ecological boundaries and carrying capacity of the planet. It is something that can be measured and that is based on scientific evidence. Some characteristics are:

- focus on environment

- based on scientific evidence

- objectively measurable.

The well-being perspective on sustainable development conceptualises sustainable development as a quality of life issue (in an intertemporal sense) rather than an environmental issue. It looks at environment as far as it concerns well-being, either directly through life-supporting functions and amenities and indirectly through offering resources for the economic process and assimilating waste. Some characteristics are:

- focus on all three pillars of sustainable development

- diverse opinions co-exist

- result of societal preferences

- contextually determined.

We argue that the various classifications of governance can be distinguished between the extremes of hierarchical governance and deliberative governance. The nature of hierarchical governance is a top down approach and vertical relations between a lead actor and other actors in society. In this strategy the lead actor, often government, is the most important player that decides and holds power. Some characteristics are: 
- decision-making by the lead actor

- vertical relation between lead actor and other societal actors

- planning and control.

In deliberative governance we see bottom up approaches and horizontal relations between all actors involved. The principle of this strategy is that all parties (state, market and civil society) share their powers and operate on an equal footing in an open deliberative way. Some characteristics are:

- decision-making by multiple actors

- horizontal relations between actors

- network management.

Furthermore, we can distinguish several characteristics that are neither pure governance characteristics, nor characteristics purely related to a certain perspective on sustainable development, but that are expressions of governance for sustainable development. We will discuss issues such as implementation strategy, commitment, uncertainty, focus, role for technical fixes, and monitoring and evaluation, also see Table 3.

- The implementation strategy that is used in governance for sustainable development depends on both the mode of governance and the perspective on sustainable development. An ecological sustainability perspective with a hierarchical mode of governance might lead to a clear plan of implementation with little discretion for the means to achieve it;

- It is often said that without commitment throughout society sustainable development will not happen easily. Different types of governance for sustainable development will invoke this commitment to a greater or lesser extent;

- Uncertainty is always an issue in sustainable development. Systems are poorly understood and forecasts for the future have large error margins. Dealing with uncertainty depends on where it is perceived and who feels responsible. This varies with the type of governance for sustainable development;

- Depending on the governance mode and the perspective on sustainable development the focus is different. The focus can lie on the output, i.e. achieving the clearly defined goal sustainable development. Sometimes the focus will be on the process of goal-setting and the search towards sustainable development.

- Technical fixes or technical solutions are one component of achieving sustainable development. They are currently widely used. Another component is behavioural change and system innovation which needs strong societal support to be successful. They are applied less often and are not considered an option in hierarchical systems unless benefits are clear for society. 
- Each type of governance for sustainable development has implications for the monitoring and evaluation criteria.

When combining the perspectives on sustainable development with the modes of governance, we propose the following conceptual framework (fig. 2.1, table 2.2) which captures within its boundaries existing efforts and theories regarding governance for sustainable development. Obviously, a typology as we propose is a significant simplification of the complex debates about the 'real' meaning of sustainable development and the huge variety in forms of governance that we see around the world. However, the aim of this typology is to take a first step in the establishment of a framework that helps scientists and policy makers to explore relevant dimensions of modes of governance for sustainable development and for setting a framework for empirical analysis.

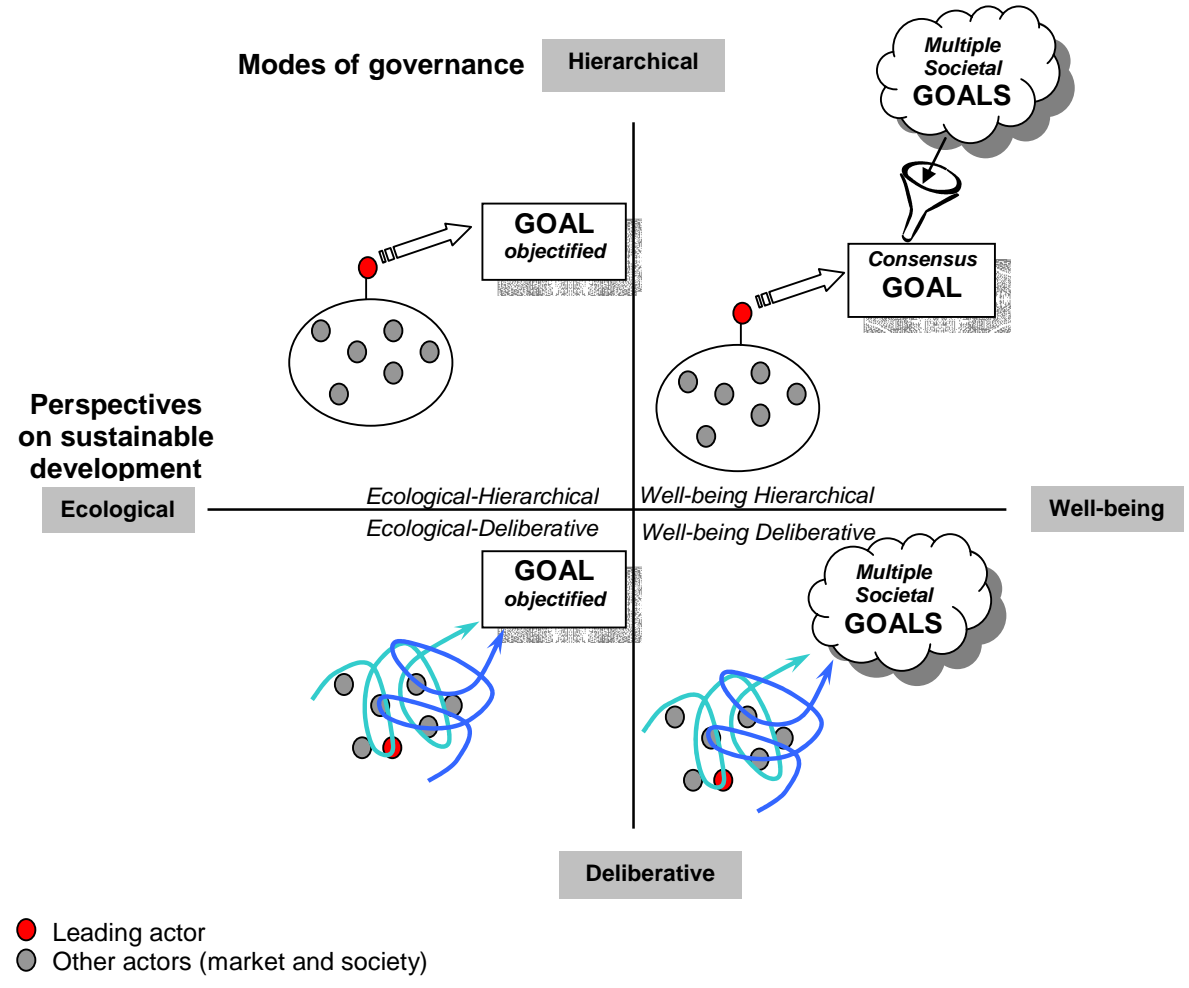

Figure 2.1: Conceptual framework of governance for sustainable development

\subsubsection{The ecological sustainability-hierarchical type}

Decisions are taken by the leading actor, often government. A vertical relation exists between the leading actor and other actors in society. Sustainable development is seen as a goal that can be objectified based on scientific evidence. Goal- 
setting is done to a large extent by the leading actor; consensus exists that development should take place within ecological limits.

Implementation of the sustainable development goal is decided upon by the leading actor in a straightforward process with little discretion for those implementing it. Solutions are mainly sought in the domain of technical fixes. Other actors are not necessarily committed to sustainable development but they follow the leader. The focus in this type is on goal achievement. Monitoring and evaluation indicators will be output oriented.

A possible danger in this system is over-simplification and concentration on remedying a few symptoms such as reducing $\mathrm{CO}_{2}$ levels. By ignoring inter-linkages that are so important in sustainable development, society might be surprised by unwanted side-effects and a transfer of problems and could find itself unable to cope with it.

\section{Views and examples}

An example of an ecological sustainability perspective on sustainable development can be found in the work of Hueting and Reijnders (2004). They state that 'longterm sustainability of society can as far as the physical environment is concerned, only be based on physical standards'. They argue that indicators for sustainable development aggregating the three aspects of sustainable development are often not meaningful. Also, involving societal actors in the construction of what sustainability is and thus of what sustainable development indicators should be, is not meaningful. Constructing sustainability indicators 'is a matter of proper division of labour between the sciences'.

An example is the Kyoto-protocol and its aim to reduce the output of greenhouse gasses. The goals are set by governments, and should be achieved by society within a given timeframe. Both goal and implementation are set by the leading actor.

An instrument that fits an output-oriented approach is cost effectiveness analysis (CEA). CEA shows in monetary terms which options are best.

\subsubsection{The ecological sustainability-deliberative type}

Representatives of the state, market and civil society decide on how best to achieve the goal of sustainable development. The goal is objectified with the help of scientific findings. Therefore, it is easier to reach consensus. Actors agree that development should take place within ecological limits. Thus, the main issue is how to get to these goals. Actors decide on the best or most wanted solutions by negotiation and learning by doing. In the science based society there is an important role for technical solutions. We see horizontal relations between the government and other actors in society in the form of networks. There is mutual interdepend- 
ence between the actors involved. A deliberative approach is followed to achieve the clear goal of sustainable development. Adaptive policy is important for finding the road towards the goal as negotiation or learning lead to new insights (Rammel and van den Bergh, 2002).

As goals are rather clear, the main focus lies on possible roads towards achieving the goals. There is a high degree of discretion regarding the implementation. Diversity in solutions is accepted. However, there is some uncertainty regarding the best way to achieve sustainable development. Therefore, monitoring and evaluation will focus both on goal achievement and on finding out more about good solutions, i.e. the problem-solving process. Knowledge on and commitment to sustainable development is widely present at the implementation level, but not so much at the level of the sustainable development concept, which is the domain of science.

The emphasis on ecology might be insufficient to understand the complexities of achieving sustainable development. However, the implementation process will reveal the problems. Still, the strong focus on technology could prevent society from exploring system innovations.

\section{Views and examples}

Brand and Karvonen (2007) dub the technocratic, expert-dominated way of looking at sustainable development the 'technical fix approach to sustainable development'. They state that 'today, the technical fix approach in sustainable development is the dominant model in industrialized countries because it retains the existing power of political and economic elites'. They show that the dominance of science and technology as described above is a legitimate danger in their quote of Dryzek ((1997) in: Brand and Karvonen, 2007): 'in its most limited sense, ecological modernization looks like a discourse for engineers and accountants'. Finally, Brand and Karvonen argue that the technocratic approach to sustainable development should not be abandoned but should be directed by society as a whole. Different types of expertise, including that of the non-experts (i.e. civil society) are all complementary and necessary. In conclusion, they criticise the rational problem solving way as being proposed as the road towards sustainable development.

An instrument that could be used by this type of governance for sustainable development is multi-criteria analysis in which weights are used for arriving at an overall evaluation of a sustainable development action. Many different solutions to sustainable development can be evaluated and the best ones will be selected based on certain criteria.

An example of the ecological sustainability-deliberative type is the work of the Intergovernmental Panel on Climate Change (IPCC) and the Millennium Ecosystem 
Assessment. The goal is clear, but implementation is left to the discretion of the signatories.

\subsubsection{The well-being hierarchical type}

The ultimate goal of sustainable development is not well defined. It is seen as the result of societal preferences and is related to well-being and the quality of life. Uncertainty regarding priorities dominates the goal-setting process. The leading actor (often government) draws upon society in the goal-setting process. From among the diverging opinions a consensus perspective is sought by the leading actor from the variety of priorities and for the sake of implementation one goal is chosen. The leading actor recognises that goal-setting is driven by the societal context. Therefore, the goal can change. However, once the sustainable development goal is clarified, the leading actor coordinates and steers the road towards sustainable development. Technical fixes, as well as behavioural change and system innovation, play an important role.

Some discretion exists in the implementation strategy. The focus lies on the goalsetting process and on goal achievement. Society participates in the goal-setting process. Commitment to sustainable development is present, but not always for the policies formulated at the top. Monitoring and evaluation of this type of governance for sustainable development deals mainly with goal achievement and investigation of changed preferences that would oblige the leading actor to adjust the sustainable development goals.

A possible danger in this system is that societal actors could be unwilling to follow the path chosen for them. Furthermore, we see tension between the uncertainty in the sustainable development priorities and the linear approach taken by the leading actor.

\section{Views and examples}

Bell and Morse (2005) observe that although sustainable development is often seen as a circular and boundless concept, its implementation is often surprisingly linear. Once goals are defined, a strategy or project document is drawn up, budget is allocated and the programme is implemented. Often blueprint projects are designed that require clarity on outputs prior to inception. They state that the awareness of the journey throughout the project should be part of project planning, and a formal structure in projects is needed that facilitates debate and learning (Bell and Morse, 2005). 
Cost-benefit analysis fits with a well-being-hierarchical perspective, in which enhanced well-being is the goal to be achieved through authoritarian decisionmaking.

\subsubsection{The well-being deliberative type}

Representatives of the state, market and civil society deliberate on the priorities for sustainable development and about the way to pursue the desired goals of wellbeing and quality of life. There are horizontal relations between the government and other actors in society. There is attention to a multitude of (soft) goals and the trade-offs between them. Goal-setting depends on the societal context. The process of defining the goals, taking action towards implementation, reframing the goals and adjusting the road towards them is an unfolding societal process dependent on learning by doing and negotiation. The co-existence of many goals is accepted and the end-point is not known in advance. Society evolves and thus the sustainable development context changes. Uncertainty in goals and implementation is overcome by deliberation and learning and adaptive policy is vital (Bagheri and Hjorth, 2007; Kemp et al., 2007; Rammel and van den Bergh, 2002).

Here governance for sustainable development is not viewed as the way to get to predefined goals and outcomes but as an open, deliberative process that helps to articulate what is wanted and desirable. It is accepted that there are different ideas of what sustainable development means for actors in various sectors, that solutions tend to be sustainable within these sectors rather than across the whole of society, that new developments bring new risks that cannot be anticipated, that sustainable development is a long-term, open-ended project that precedes and supersedes limited-term, democratically elected governments and, finally, that it involves making choices and perhaps trade-off decisions on highly contested issues (Farrell et al., 2005). Technical fixes play a minor role. In general context-sensitive solutions are sought, including behavioural change and system innovation. Commitment to sustainable development is found throughout society. The process towards sustainable development is more important than achieving a pre-defined goal. Monitoring and evaluation will be focused on the process and on how to deal with new insights.

A drawback in this type is that uncertainty in goals and processes make it difficult to set the priorities and decide on implementation. Society might be blocked from taking action by indecisiveness.

\section{Views and examples}

Voß et al (2006) propose reflexive governance as an answer to dealing with sustainable development. A characteristic of reflexive governance is that it under- 
stands itself to be part of the dynamics which are governed. Broader dynamics, which are not usually considered to be part of governance, are acknowledged to also play an important role in shaping societal development and therefore become part of governing (e.g. science, public discourse, social networking, technological development). Reflexive governance acknowledges that governing activities are entangled in wider societal feedback loops and are partly shaped by the (side-) effects of its own working.

An example of a tool used in this type could be 'transition management'. Transition management is a forward-looking and adaptive model for steering societal change towards sustainable development goals with a great orientation towards system innovation. Transition management is a new steering concept that relies on 'Darwinistic' evolutionary processes of guided variation and selection instead of planning. Industrial interests in sustainable development are being exploited through innovation policy. Different trajectories are explored and flexibility is maintained, which is exactly what a manager would do when faced with great uncertainty and complexity. It is being used in the Netherlands as a model for sustainable development, for which see the articles on the Dutch energy transition (Kemp and Loorbach, 2005; Loorbach and Kemp, 2007).

Table 2.2 provides a summary overview of the characteristics of the four main types of governance for sustainable development as discussed in this chapter.

Table 2.3 gives an overview of 'expressions of governance for sustainable development', for each of the four typologies. These are issues such as commitment, implementation strategy, monitoring and evaluation. They have been addressed in the descriptions of each typology, and can be seen to exist at the interface of governance and sustainable development. 


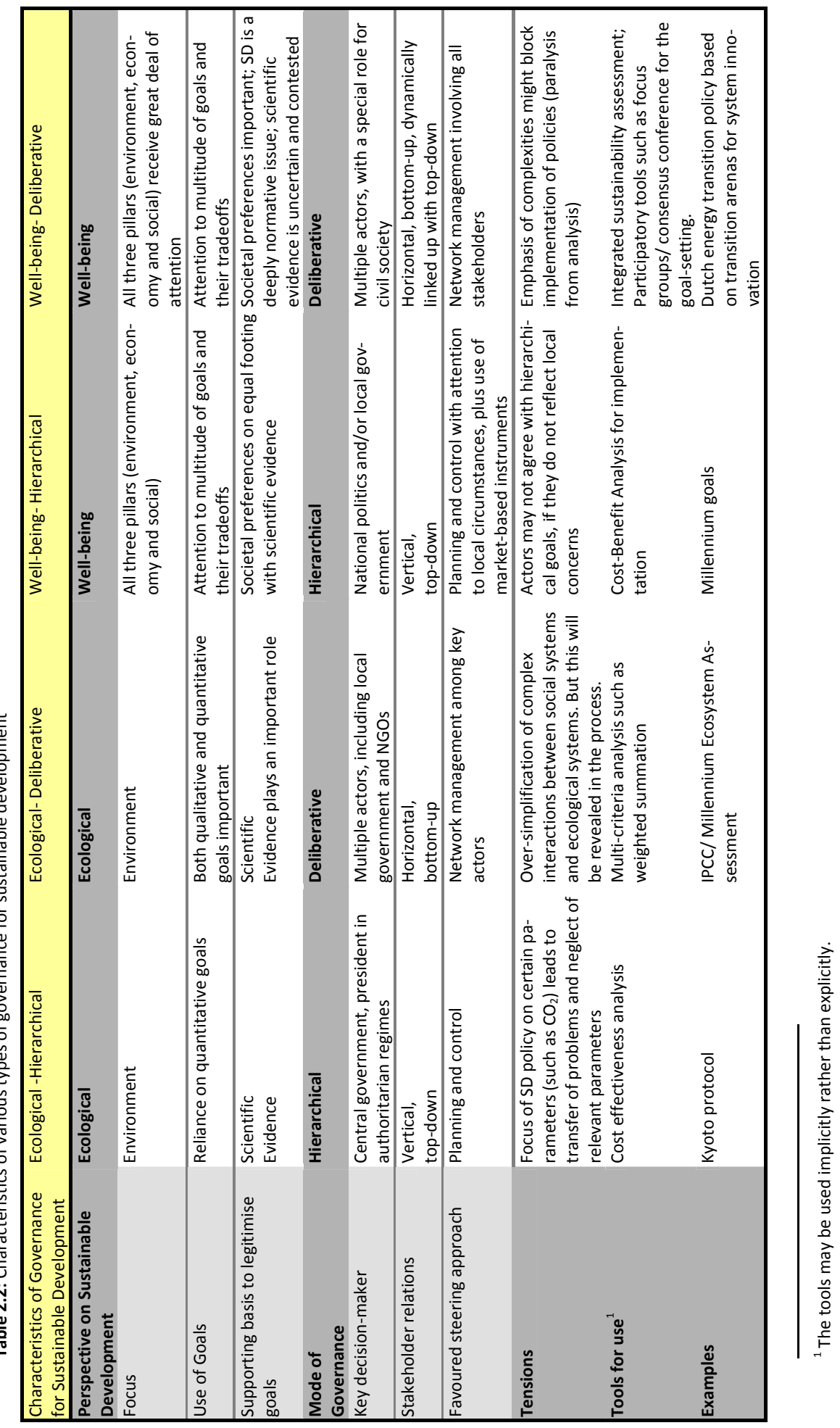




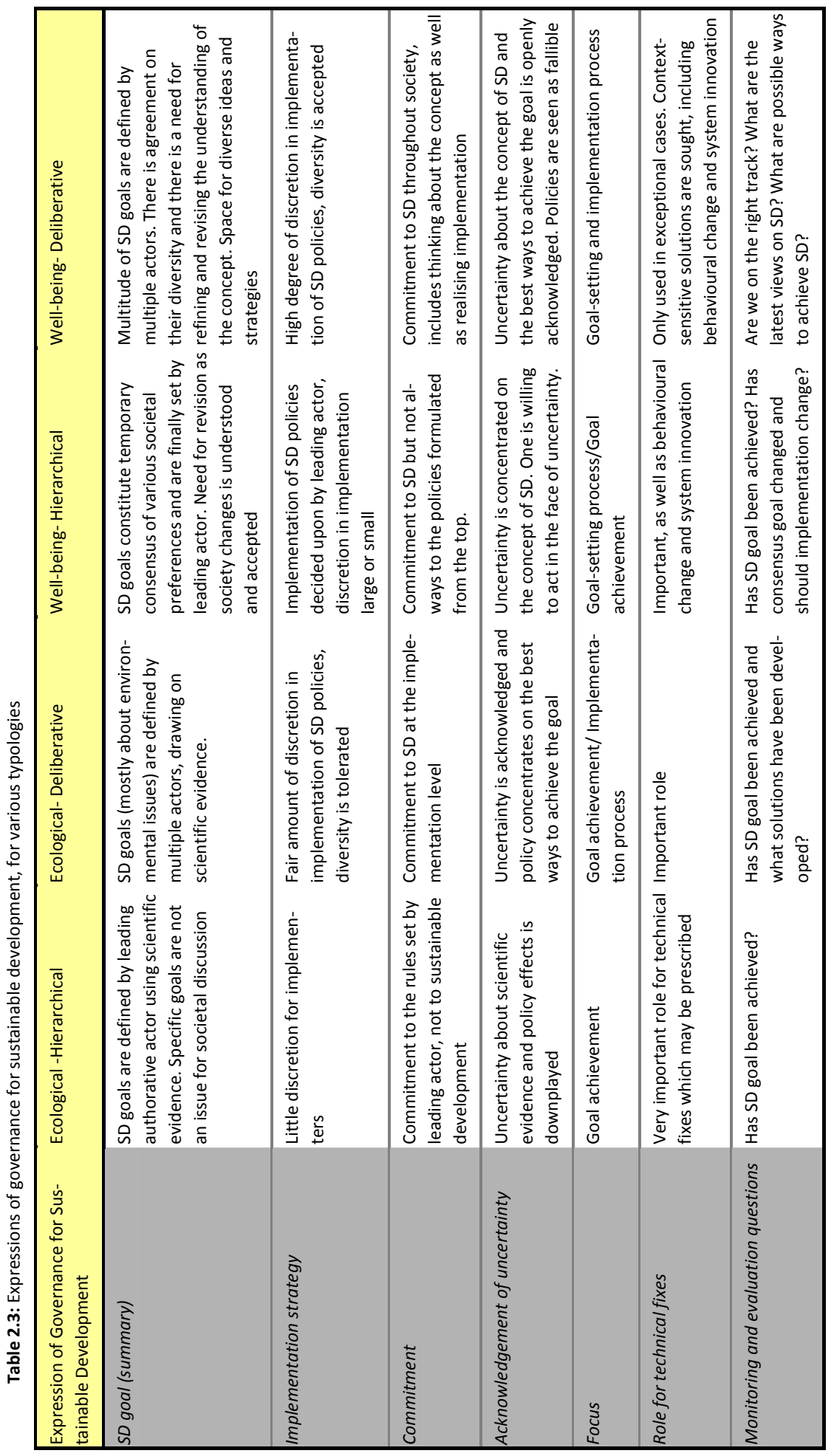




\subsection{Conclusion}

In this chapter we assume that sustainable development cannot be achieved without governance because of its nature: it is normative and requires collective action. We argue that the many perspectives on sustainable development can be described meaningfully between the extremes of the ecological sustainability perspective and the well-being perspective. The variety of modes of governance can be captured between hierarchical governance and deliberative governance. From this we derive four ideal-types of governance for sustainable development.

The typology does not account for all the complexities that we may observe in society: national government is likely to be committed to both well-being and to environmental protection, as is local government; they may act in an authoritarian manner or a more reflexive manner in different cases. In the formulation of sustainable development strategies, policies and goals they may rely on deliberative processes with key actors, involving business and civil society organisations, and overruling other societal actors.

Our typology seeks to explore relevant dimensions of governance for sustainable development, to prepare the ground for empirical research into implementation of sustainable development.

It is possible that we find that the typology is too crude and that the modes of governance for sustainable development are more diverse than our framework can handle. However, we believe that the typology serves a useful role for discussion and for opening up a new trajectory for research into understanding and improving implementation of sustainable development. One could think of the analysis of governance for sustainable development within nations and across nations and domains. With the framework we may be able to map the evolution of modes of governance for sustainable development and their accompanying processes and instruments, or one could think of mapping the various modes of governance for sustainable development within one case. We might also follow governance for sustainable development over time, or identify the matches and mismatches of processes, governance instruments and perspectives on sustainable development at various stages of the implementation process.

The framework may thus be used to identify the method in the madness: it has the potential to structure and facilitate governance for sustainable development, as it provides leverage points for an evaluation of the effects of sustainable policy and the design of possible solutions through sustainable strategies. In this thesis it is used to assess policy and practices of sustainable development. An evaluation of the framework can be found in chapter 8 . 


\section{Sustainable development: from policy to principle}

In recent years more and more policy has been specifically aimed at implementing sustainable development. Especially since the commitment to the Johannesburg Plan of Implementation (UN, 2002), many countries have developed a national sustainable development strategy. This chapter briefly maps out the policy developments at various scale levels (European Union, The Netherlands, province of Limburg) with respect to sustainable development and a focus on the province of Limburg: it investigates the strong and weak points of these policies, and it poses the question whether sustainable development needs specific policy, or whether it would be better to use sustainable development as a guiding principle for policy and what that would mean.

\subsection{A brief history of sustainable development}

Sustainable development became an issue of global interest after the publication of the Brundtland report in 1987 (see for example EU, 2008b; Province of Limburg, 2009a; VROM, 2003; 2009; Zijst, 2006). But already before this date there was considerable interest in environmental protection. The 1972 report "Limits to Growth" and the UN Conference on the Human Environment (UNCHE) of that same year stimulated world-wide debate on environmental degradation (VROM, 2001). As a response, the Dutch government developed in 1972 an "urgency policy note on the environment" that focused on a great number of environmental problems (VROM, 2001). The Netherlands reacted to the Brundtland report in 1988 with the report "concern for tomorrow" which focused on environmental threats and their status. The resulting debate led to the first Dutch Environmental Policy Plan in 1989. A special aspect of this national policy plan is that it did not focus on separate environmental problems as in the previous 20 years of Dutch environmental policy, but " [ . . . ] called for comprehensive, integrated and long-term approaches, following a thematic perspective [ . . . ]" (Zijst, 2006). The Brundtland report served as input to the 1992 UN Conference on Environment and Development (UNCED). What is special about the Brundtland report is that it explicitly links environmental degradation with social problems and economic stagnation (VROM, 2001). The Rio conference resulted, among others, in Agenda 21, an overall guiding document for sustainable development. In 1997 the Netherlands developed a policy note linking environment and the economy. Its main message was that a total decoupling of environmental pressures and economic growth is needed for sustainable economic growth (VROM, 2001). Also in 1997, the European Union included sustainable de- 
velopment in the Treaty of Amsterdam as the overarching long-term goal of the EU (art 1.2) and as a topic to be integrated into all community policies and actions (art 3c) (EU, 1997; Province of Limburg, 2009a). The EU adopted its first Sustainable Development Strategy (SDS) in 2001 at the Goteborg European Council. This was further complemented by adding an external dimension in 2002 in view of the 2002 Johannesburg summit (EU, 2006). The Lisbon Strategy of 2000, aiming at making the EU the "most competitive and dynamic knowledge-based economy in the world, capable of sustainable economic growth with more and better jobs and greater social cohesion" (EU, 2000) by 2010, was complemented by the Goteborg strategy or EU- SDS in 2001 dealing with threats to Europe's quality of life. "The EU SDS forms the overall framework within which the Lisbon Strategy [ . . . ] provides the motor for a more dynamic economy" (EU, 2006). Meanwhile, in the Netherlands, the 4th Dutch Environmental Policy Plan of 2001 was established with sustainable living at its core. However, its focus is still primarily on environmental issues (Zijst, 2006). Even though most nations of the world committed themselves to the Rio declaration and Agenda 21, implementation remained a difficult issue (UN, 2001b). In the 2002 Johannesburg Plan of Implementation nations were explicitly asked to develop a national sustainable development strategy and begin its implementation by 2005 (UN, 2002). In 2003 the Dutch government responds with the development of an action programme for sustainable development rather than a strategy (VROM, 2003). At the provincial level, sustainability was mentioned in the coalition agreement of Limburg in 2003 as a broad concept within the overall vision: "Limburg should be a vital region with citizens full of initiative in a sustainable, safe and attractive environment make use of available opportunities" (Province of Limburg, 2003). However, this was not initially followed by a specific programme, budget, actions or a deputy on the topic. Only in 2005 a policy programme was developed and a deputy became responsible for the topic (Province of Limburg, 2005a). In 2006 the provincial spatial plan (Province of Limburg, 2008) states that sustainability is the starting point of development of the quality region Limburg as a response to global and European strategies for sustainable development. In the meantime, at EU level the EU SDS was revised by means of a broad participatory review process in 2004. The renewed strategy was adopted in 2006 (EU, 2006). It asks the Member States to complete national sustainable development strategies by June 2007. Furthermore it states that voluntary peer reviews of national sustainable development strategies should start in 2006 (EU, 2006). The Netherlands was the first country to undergo such a peer review in 2007. The Peer Review committee concluded that the existing Dutch action programme on sustainable development was not a sufficient response to deal with persisting unsustainable trends. It says that the focus is predominantly environmental, it lacks a framing vision, activities are not linked, and it lacks ownership in society. Furthermore, synergies and trade-offs between goals and policies are lacking and effective 
cooperation between government departments and levels is missing. The review panel recommends the development of sustainable development framework or strategy in a broad participatory process (Dalal-Clayton and Krikhaar, 2007). Also on the EU SDS criticism can be found, for instance in Pallemaerts (2006). According to him the relationship between the SDS and the Lisbon Strategy is not clear. One view is that the SDS is the environmental dimension to the Lisbon Strategy (next to the economic and social dimensions), while another view is that the SDS is an independent strategy, complementary to the Lisbon Strategy. In practice both strategies seem to be disconnected. Furthermore, Pallemaerts (2006) states there is no definition of sustainable development; there is not a central strategic objective; the political commitment to sustainable development is ambivalent; different institutions have clearly different views on the purpose, scope and status of the SDS and all in all this does not blend together into a coherent overall policy.

In 2007, after new elections at the provincial level, a new coalition agreement in Limburg was reached that dubbed sustainable development one of seven important directional factors for provincial activities (Province of Limburg, 2007b). This was followed in 2008 by a policy framework for Limburg on "sustainable development and Cradle to Cradle" (Province of Limburg, 2009a). The document mentions European key challenges for sustainable development and the Dutch priorities developed in the Cabinet's approach for sustainable development of 2008. This latter was developed after the peer review and states that sustainable development will be a guiding issue for all policy (VROM, 2008). In 2008 the EU launched a major Recovery Plan for growth and jobs in response to the economic and financial crisis (EU, 2009d). According to the 2009 review of the EU SDS green growth is meant to occur: "Work to overcome the crisis is ongoing, in particular in the context of the Lisbon Strategy for growth and jobs, with a focus on green growth. In the short term, green measures help to revive the economy and create jobs. In the medium and long term, they also stimulate new technologies and reduce our impact on climate change, the depletion of natural resources and the degradation of ecosystems." The review takes stock of progress with EU policy in the areas covered by the EU SDS and provides input for reflection and debate on sustainable development. One element that should be improved is greater synergy with the Lisbon Strategy and other cross-cutting EU strategies. However, a decision on whether a comprehensive revision of the EU SDS is necessary will be taken at a later stage (EU, 2009d). Currently, the EU is working on Europe2020, which is the EU's growth strategy for the coming decade. Aims for the EU are to become a smart, sustainable and inclusive economy. This strategy has not been taken into account in this thesis. See figure 3.1 for a timeline of the developments described above. 


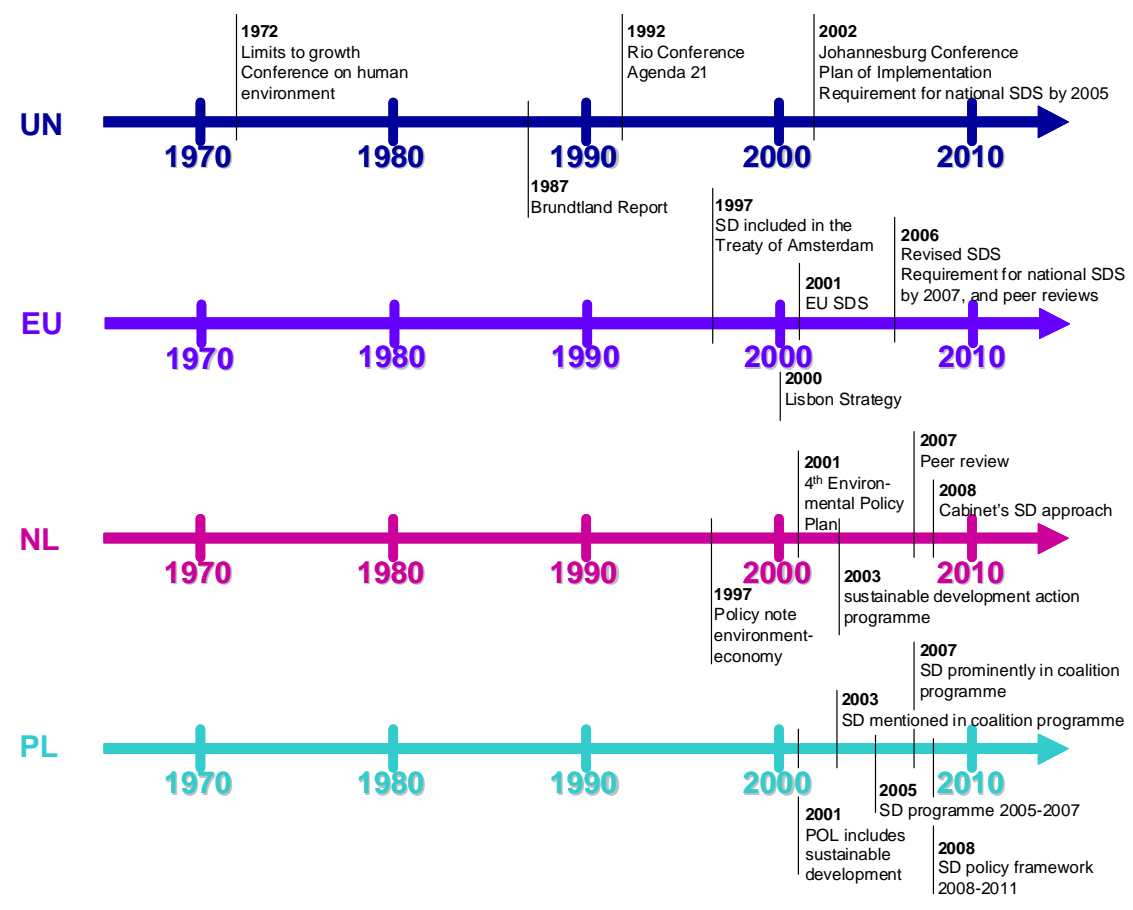

Figure 3.1: Timeline of sustainable development policy and events at various scale levels (UN: United Nations; EU: European Union; NL: Government of the Netherlands; PL: Province of Limburg)

For a long time sustainable development was seen from an environmental perspective, even after the Rio Conference where sustainable development was introduced as an integrative, interdisciplinary concept dealing with inter- and intragenerational equity issues. Citizens of Limburg confirm this perspective: $53 \%$ see that sustainable development means a balanced development of the social, economical and environmental domains, whereas the majority chooses environmental terms when asked for concrete issues dealing with sustainable development (see chapter 4). Furthermore, the timeline (fig 1 ) shows that it takes considerable time for a global issue to be transformed into regional policy. The next section addresses the strengths and weaknesses of policies for sustainable development at various scale levels.

\subsection{Current sustainable development policy analysed}

Governance is the sum of actors, institutions, processes, and instruments that a society puts in place to pursue a common interest. A government is a common way of dealing with this, but governance is much broader. It is the interplay of state, market and civil society; their relations, their laws, their agreements, their actions and their plans for achieving issues of common interest. In this chapter we discuss 
the plans, or, in other words, the policy for sustainable development as an important element of governance for sustainable development. This chapter investigates which barriers exist in implementing sustainable development in current sustainable development strategies. Three scale levels are investigated: EU policy, Dutch national policy and regional policy of the province of Limburg. A first analysis is made based on the typology for governance for sustainable development that was developed in chapter 2 (Zeijl-Rozema van et al., 2008). This typology distinguishes different perspectives on sustainable development, ranging from an ecological perspective (sustainable development = environmental protection) to quality of life. It combines these perspectives with different modes of governance that are captured between hierarchical governance (one actor of the group of actors involved in sustainable development, often government, is taking decisions and leading the way) and deliberative governance (all actors interact in equality). Van ZeijlRozema et al. (2008) contend that "the debate on governance for sustainable development will be clarified if the perspective on sustainable development and the mode of governance for achieving it are made more explicit. Problems that are now exclusively associated with sustainable development might well be problems of governance for sustainable development."

The typology will serve to map out the differences and commonalities of the three policies on different scales. Criteria that were used to analyse the policies are :

regarding the perspective on sustainable development:

- focus

- fixed/fuzzy goals

- supporting basis to legitimise goals

regarding the mode of governance:

- key-decision-maker

- stakeholder relations

- favoured steering approach.

Furthermore, a number of "expressions of governance for sustainable development" have been defined, that serve as a cross-check to determine the type of governance for sustainable development type of each policy. These are:

- sustainable development goal

- implementation strategy

- commitment

- acknowledgement of uncertainty

- focus

- role for technical fixes

- monitoring and evaluation questions 
For each sustainable development strategy these characteristics have been investigated (see Annex 1 of this chapter). Table 3.1 shows the characteristics of governance for sustainable development and table 3.2 the expressions of governance for sustainable development. In the text below this is further explained. The position of each sustainable development strategy (SDS) is plotted in the theoretical framework, see figure 3.2.

Table 3.1: Characteristics of governance for sustainable development. Small letters mean there is some tendency towards a certain mode of governance or perspective on sustainable development within the policy. Capital letters mean there is a clear indication.

\begin{tabular}{lll}
\hline $\begin{array}{l}\text { Characteristics of Governance for Sustainable } \\
\text { Development }\end{array}$ & \\
\hline Perspective on Sustainable Development & Ecological & Well-being \\
Focus & & $\mathrm{EU}, \mathrm{NL}, \mathrm{PL}$ \\
Use of Goals & $\mathrm{eu}, \mathrm{nl}, \mathrm{pl}$ & $\mathrm{EU}, \mathrm{NL}, \mathrm{PL}$ \\
Supporting basis to legitimise goals & $\mathrm{NL}$ & \\
\hline Mode of Governance & Hierarchical & Deliberative \\
Key decision-maker & $\mathrm{EU}, \mathrm{NL}, \mathrm{PL}$ & \\
Stakeholder relations & $\mathrm{EU}, \mathrm{NL}, \mathrm{PL}$ & $\mathrm{pl}$ \\
Favoured steering approach & $\mathrm{EU}, \mathrm{NL}, \mathrm{PL}$ & $\mathrm{pl}$ \\
\hline
\end{tabular}

Table 3.2: Expressions of governance for sustainable development

\begin{tabular}{|c|c|c|c|c|}
\hline $\begin{array}{l}\text { Expression of Governance for } \\
\text { Sustainable Development }\end{array}$ & $\begin{array}{l}\text { Ecological - } \\
\text { Hierarchical }\end{array}$ & $\begin{array}{l}\text { Ecological- } \\
\text { Deliberative }\end{array}$ & $\begin{array}{l}\text { Well-being- } \\
\text { Hierarchical }\end{array}$ & $\begin{array}{l}\text { Well-being- } \\
\text { Deliberative }\end{array}$ \\
\hline Sustainable development goal & & & $\mathrm{EU}, \mathrm{NL}^{3}, \mathrm{PL}^{3}$ & \\
\hline $\begin{array}{l}\text { Implementation strategy } \\
\text { Commitment }^{4}\end{array}$ & & EU & $\mathrm{EU}, \mathrm{NL}, \mathrm{PL}$ & \\
\hline Acknowledgement of uncertain & & & & \\
\hline Focus & $\mathrm{NL}, \mathrm{PL}$ & & EU & \\
\hline Role for technical fixes & & PL & EU, NL & \\
\hline Monitoring and evaluation & $N L, P L$ & PL & EU & \\
\hline
\end{tabular}

European Union sustainable development strategy (EU SDS) ${ }^{6}:$ The EU uses a wellbeing perspective on sustainable development. It is not explicitly mentioned what the different societal or normative choices have been for well-being. However, the EU SDS recognises the need to regularly review the priorities given the progress made. The document has been drawn up by means of a broad societal review process. Instruments to be used are financial and economic instruments, as well as communication and mobilisation of actors. The EU has a leading role in monitoring and setting priorities with the help of stakeholders as mentioned in the review

\footnotetext{
${ }^{3}$ But no mention of revision of the goals or societal process and variety

${ }^{4}$ Not enough information about commitment

${ }^{5}$ Uncertainty is only mentioned sporadically in EU SDS and PL, but not in Dutch SDS

${ }^{6}$ EU 10917/06 Renewed EU sustainable development strategy (EU SDS)
} 
process, but member states should implement. According to the typology this is more a hierarchical mode of governance with a well-being perspective.

The "expressions of governance for sustainable development" show a consistent picture: the EU SDS provides discretion for implementation to the member states, the focus of implementation is on goal-setting, implementation and revision of priorities, which is seen also in the monitoring and evaluation requirements. All in all, the EU SDS is document that shows consistently a well-being hierarchical type. Some other issues are: in the SDS a broad vision on Europe is included. However, from the SDS it does not become clear how the key challenges have been defined in relation to this vision. Monitoring will report on progress in the key challenges, but not on achieving the overall vision.

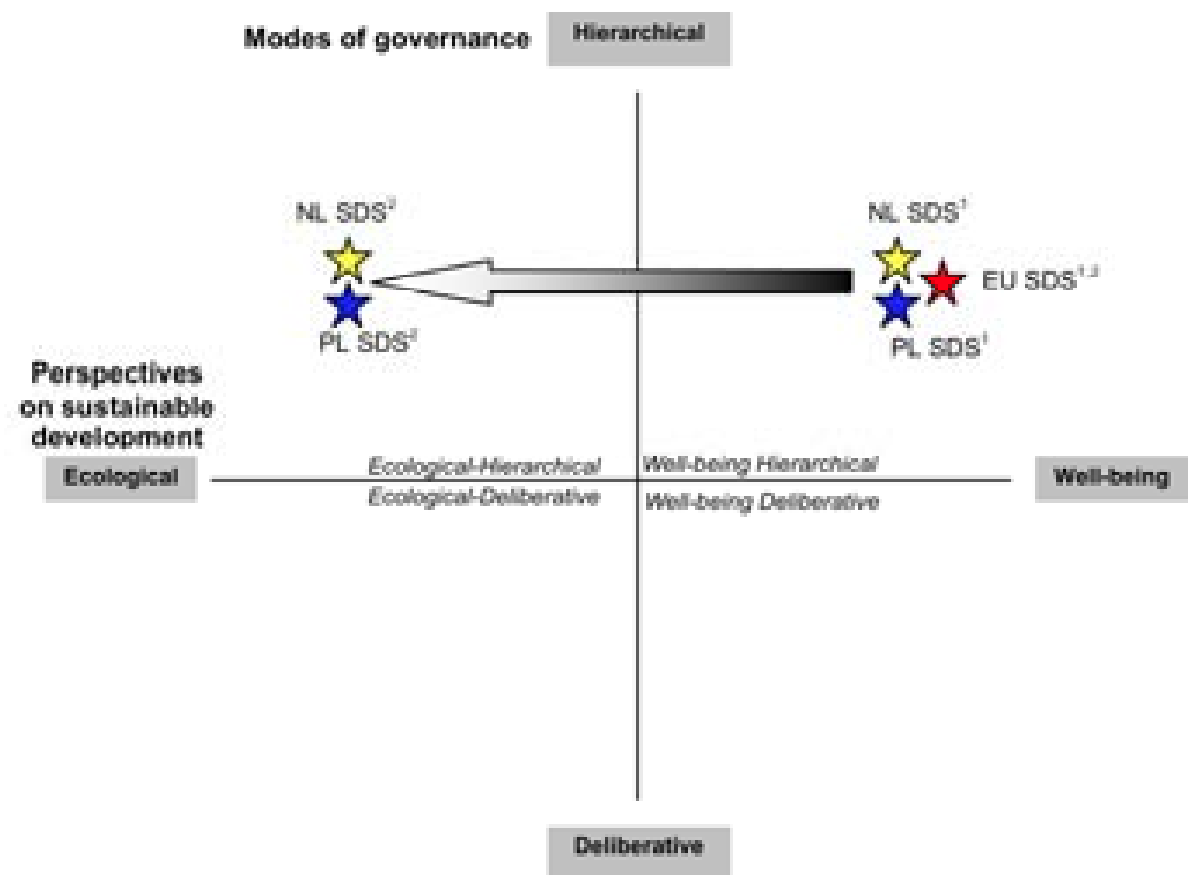

Figure 3.2: The theoretical framework of chapter 2 with the position of the SDS of the EU, NL and PL. The numbers signify the sustainable development perspective mentioned in the policy (1) and the actual interpretation of sustainable development as mentioned in the icon projects and actions (2). The arrow shows the shift from policy definition to actual interpretation of SD in the case of the NL and PL SDS.

Dutch sustainable development strategy (NL SDS) ${ }^{7}$ : The Netherlands uses a wellbeing perspective on sustainable development. However, no mention is made of the deep normative character of sustainable development and the need to involve societal actors in determining focus, and the possible changes in focus depending

\footnotetext{
${ }^{7}$ VROM DGM/BREM2008050615 Kabinetsaanpak Duurzame ontwikkeling (KADO)
} 
on developments in society and in knowledge. A sign pointing towards some acknowledgment of the normative character is seen in the forerunner of the current SDS, the 2003 Sustainable Development Action Programme, which explicitly mentioned that sustainable development is a continuous learning process (VROM, 2003). The NL SDS is based on recommendations from a peer review process and the sustainability outlook, but neither of these involved active participation of society. In the way the document was developed national government has played a directive role. In implementation there is some discretion for the implementers, but government has defined the goals. Government sees its role in implementation as directing, facilitating, taking the lead and safeguarding progress. According to the typology this SDS is an example of the well-being hierarchical type.

The expressions of governance show some deviation: the focus is on goal achievement and monitoring seems also to focus more on achieving the goals than on process or revision, which fit more in the ecological-hierarchical type.

So we see several important issues missing: in a well-being perspective society should be consulted on their ideas about well-being, goals should be seen as subject to changes in knowledge or in society, a focus on process should be accompanied by monitoring on process and not only on outputs. Behavioural change could be made more prominent.

Some other observations: the Dutch SDS mentions the EU and global efforts. However, no link is made with them. The NL SDS does not develop a clear vision on how sustainable development should be achieved in the Netherlands. There is however mention that monitoring exercises should answer how sustainable the Netherlands has become or how it performs in relation to its neighbours. This shows an important link back from the themes to the bigger picture of sustainability. But no mention is made of how the proposed actions contribute to the overall vision. The six themes and icon projects mentioned have an emphasis on environmental problems. This gives the impression that the focus is still on environment, as was also commented on by the peer review (Dalal-Clayton and Krikhaar, 2007).

Province of Limburg sustainable development strategy (PL SDS) ${ }^{8}$ : The Province of Limburg uses a well-being perspective on sustainable development, however, without acknowledging the different societal or normative choices for what that well-being should entail. The document has been drawn up without stakeholder consultation, but it is based on the Provincial Environmental Plan (POL) which was set up in 2001 along the three domain approach with broad stakeholder involvement. However, the goals defined can be interpreted as the provincial administration's choice. It defines several roles for the provincial administration, some are more directive, while others are more facilitating. However, the lead for implemen-

\footnotetext{
${ }^{8}$ Provincie Limburg, Beleidskader Duurzame Ontwikkeling/ Cradle to Cradle 2008-2011
} 
tation lies with the province. Because there is explicit mention of space for other stakeholders to take the lead, we identified this as a mild form of hierarchical governance.

So, according to the typology the province of Limburg can be situated in the wellbeing hierarchical type. The "expressions of governance for sustainable development" provide the means to cross-check this. With respect to the sustainable development goal and the implementation strategy the provincial government seems indeed to fit into the well-being-hierarchical type. Regarding uncertainty and commitment the available information is inconclusive. However, the focus on goal achievement and implementation, the strong emphasis on cradle to cradle as a solution for innovation in design and production, and the monitoring focus on goal achievement place the province more in the ecological perspective on sustainable development. This can also be seen as a more traditional approach of government activities. Even though the process is said to be most important, there is focus on goal achievement, which seems inconsistent. So we see several important issues missing: in a well-being perspective society should be consulted on their ideas about well-being, goals should be seen as subject to changes in knowledge or society, a focus on process should be accompanied by monitoring on process and not only on outputs and more freedom in solutions needs to be allowed, also looking at behavioural change.

Some other observations on the Limburg SDS: an overall vision on Limburg is not included, nor is there an sustainable development vision. A vision exists in the coalition agreement, but this is not referred to in the SDS. It is unclear why the defined goals were chosen. The relation with EU SDS and the Dutch SDS is unclear. They are mentioned, but their themes and key challenges are not used for the Limburg SDS, except for the clear mention of the importance of C2C in the Dutch SDS. In monitoring focus is on achieving the goals, but not on the progress towards realising the vision of Limburg. The Province of Limburg states in its Beleidskader, which we use here as the provincial sustainable development strategy, that sustainable development is not a separate policy field but rather a connector through all sectors.

Based on the analysis of these three policies, some general observations can be made. Each SDS attempts to tackle the complex issue of sustainable development by breaking it down into specific activities. However, it is unclear how these were chosen and how they contribute to achieving the desired future. A description of the desired future is even lacking in the Dutch and Limburg SDS. Each SDS does explain what sustainable development means and what elements are part of sustainable development, but this is not made concrete into a picture of the future according to these criteria. Although the Dutch SDS and the Limburg SDS see sustainable development from a well-being perspective with an inherent normative character, society was not involved in setting the goals and priorities. Nor do these 
documents acknowledge the fact that societal goals can change and that regular reviews of issues and priorities are needed, as does the EU SDS. Strikingly, no link is made between the scale levels, although sustainable development is meant to happen at the local level. It seems logical that a lower level SDS would build on a higher level SDS by making issues more concrete or even adding region-specific issues. The monitoring requirements mentioned in the documents show emphasis on outputs rather than on processes, and focus on the parts rather than the whole. Only the Dutch SDS mentions that monitoring of the country's progress towards sustainability as a whole needs to be addressed.

We see a consistent disregard of how actions contribute to achieving the desired future. The focus is more on parts than on the whole of the future vision, which would be satisfactory, if it were accompanied by first a zoom-in phase, that clearly shows that certain actions are necessary for realising the desired future, followed by a zoom-out phase to show how actions have contributed to realising the future. The Dutch SDS says that many themes can be placed within the focus of sustainable development and that in general almost all societal domains and policy topics have a link with sustainable development. However, the logical consequence, to place sustainable development at the heart of all actions, is not taken. There are at EU, Dutch and Limburg level special projects, themes, and key challenges. There is a special policy document on sustainable development. However, sustainability guidance for all decisions and actions is lacking. The question we can and should ask is, therefore, whether sustainable development policy is the right tool to help to operationalise sustainable development.

\subsection{From policy to principle, and corresponding criteria}

As it is, the policies discussed here are a barrier to an integrated approach by their lack of links between scale levels, their focus on environment, and their approach that places sustainable development and associated icon projects in a special niche. In the previous section we have seen that current sustainable development policy at the level of the EU, the Netherlands and the province of Limburg has integratedness as a starting point: sustainable development is a cross-cutting issue and is a process more than anything else. What would it mean if these policies would really pursue integratedness and operationalise sustainable development as a crosscutting issue? That would mean that every action, every design, every production process and every decision should be taken in the light of sustainable development. Some ingredients are needed to make this successful. First of all, a broad vision of the desired future is important. A vision is not the same as a blueprint. A vision is a general idea of the direction society should move in, with general ideas about important values that need to be included. Box 3.1 gives an overview of the overall 
vision of the EU, the Netherlands and Limburg. This overall vision is not specifically focused on sustainable development.

This vision, which is a description of the desired future, can be designed by science, advisory councils, policy makers or in cooperation with society. But, the parties who take part in creating the vision will have a great influence on the outlook of the desired future. In consequence there will be an impact on the commitment towards achieving the vision of the various groups in society. It is therefore, strategically important to involve at least some stakeholders. Important is that the vision should allow for deviations, and that it is checked against the sustainable development concept. However, how can we check against a concept that is so complex?

\section{EU vision (EU, 2006)(p2):}

"[...] a dynamic economy with full employment and a high level of education, health protection, social and territorial cohesion and environmental protection in a peaceful and secure world, respecting cultural diversity."

\section{NL vision (Government of the Netherlands, 2007) (p6, 18, 30, 40, 60, 72)}

The country has an active international and European role, an innovative, competitive and enterprising economy, a sustainable living environment, social cohesion, a society where people feel safe and respected and where government and the public sector are decisive and accommodating

\section{PL vision (Province of Limburg, 2007b) (p3):}

Limburg is a self-confident European province that starts up new developments as well as negotiates with the Hague and Brussels. Citizens want a society that provides space for acting independently, but where social cohesion and social stability exist and are maintained. Quality of life and a good, healthy and relaxed society go hand in hand with perspective on work and income. People want a more relaxed society that provides personal and collective opportunities for prosperity and well-being. Limburg is a province where social cohesion provides significance to the lives of many people, where a high quality of the living environment exists and where economical potentials are high. On that basis we want to build on, while keeping an eye on, and making use of, the sustainable cohesion between investing in people, investing in the value of our living environment and investing in the transformation towards an innovative economy.

Box 3.1: Examples of the visions of EU, NL and Limburg

Subsequently, policy and actions should be designed to help realise this vision. A policy is a plan that contributes to the realisation of the overall vision. An action is a 
concrete activity to fulfil the goals. These policies and actions also need to undergo a sustainability check. It may seem very similar to what the EU, NL and PL sustainable development strategies are doing, but is fundamentally different. Instead of defining key challenges for sustainable development, which is the current practice, key challenges should be defined for society to achieve its goals. And these goals should be drawn up with sustainable development in mind. The actions to realise the desired future would include for instance the national budget, social cohesion, military, etc. This means that every single decision and action should contribute to the overall vision with its sustainability emphasis, and should undergo the sustainable development check. In the end, evaluation of sustainable development is not an evaluation of implementing specific sustainability actions, but an evaluation of developments towards the desired future from a sustainability perspective (see section 3.3.2 for two examples). In this way, sustainable development will truly become a process. It is of vital importance to understand that sustainable development is not the goal to be achieved; the goal is to achieve the desired future. Sustainable development is a way in which to realise that future.

\subsubsection{Checklist for sustainable development}

The previous section mentions a sustainability check for the vision, policy and actions. For this purpose we could think of using a checklist for sustainable development. To some extent, such checklists exist for certain sectors. For instance for Cradle to Cradle several checklists for buildings and design exist: DPL (Sustainability Performance of a Location), GPR (Municipal practical guideline), LEED (Leadership in Energy and Environmental design), EPL (Energy performance at a location), Greencalc, BREEAM (Building Research Establishment Environmental Assessment Method) (Province of Limburg, 2010b; Senter Novem, 2008). However, it would be more useful to have some guiding principles for sustainable development, based on which each sector can make its specific checks. But what should these guiding principles look like? The operationalisation of the Brundtland definition into a notion of interaction and balance between the three domains, plus attention to the consequences of our actions on our direct environment at present, on the future and elsewhere is still not very easy to work with. The three SDSs studied offer some insights. The Limburg SDS mentions that sustainable development requires awareness and understanding of societal needs, cross-boundary as well as forwardlooking and integrated thinking, multi-disciplinary working, learning how to deal with uncertainty and finding solutions in a critical, creative and innovative way. Furthermore, it asks for coordination, transparency, tailor-made solutions and balance (Province of Limburg, 2009a). The Dutch SDS mentions that sustainable actions should focus on efficient use of resources, reducing energy consumption and with a conscious use of the earth's resources. Also we should take into account the impact of our actions on the future and see the Netherlands in relation to the 
world. Furthermore, capacity for innovation is needed (Province of Limburg, 2009a). The EU SDS says that short-term action is required, whilst maintaining a long-term perspective. The main challenge is to gradually change our current unsustainable consumption and production patterns and the non-integrated approach to policy-making. Guiding principles for sustainable development have been identified (EU, 2005b) which are included in the SDS. Key objectives of sustainable development are environmental protection, social equity and social cohesion, economic prosperity and meeting the international responsibilities. Policy guiding principles are: promotion and protection of fundamental rights, solidarity within and between generations, open and democratic society, involvement of citizens, involvement of businesses and social partners, policy coherence and governance, policy integration, use best available knowledge, precautionary principle and polluters pay principle (EU, 2006). These three policy documents show some similarities. They address the integrated approach, the quality of society, the future, impact elsewhere, innovation, and to some extent dealing with uncertainty. Furthermore, transparency on trade-offs is mentioned as a general principle. Table 3.3 gives an overview of what each policy says about each topic.

Table 3.3: Guiding principles of sustainable development in three strategies

\begin{tabular}{|c|c|c|c|}
\hline & EU SDS & NL SDS & PL SDS \\
\hline $\begin{array}{l}\text { Integrated } \\
\text { approach and } \\
\text { coherence }\end{array}$ & $\begin{array}{l}\text { Integrated approach to } \\
\text { policy-making, policy } \\
\text { coherence, policy inte- } \\
\text { gration }\end{array}$ & $\begin{array}{l}\text { Coherent effort for devel- } \\
\text { opment of economy, social } \\
\text { development and conscious } \\
\text { use of Earth }\end{array}$ & $\begin{array}{l}\text { Cross-boundary, inte- } \\
\text { grated thinking, multi- } \\
\text { disciplinary working, } \\
\text { coordination }\end{array}$ \\
\hline $\begin{array}{l}\text { Quality of } \\
\text { society }\end{array}$ & $\begin{array}{l}\text { Social equity and social } \\
\text { cohesion, economic } \\
\text { prosperity, promotion } \\
\text { and protection of fun- } \\
\text { damental rights, open } \\
\text { and democratic society, }\end{array}$ & $\begin{array}{l}\text { Development of people, } \\
\text { societies and the world. } \\
\text { Create fair opportunities } \\
\text { An innovative economy, } \\
\text { quality of the living envi- } \\
\text { ronment, social participa- } \\
\text { tion and cohesion, well- } \\
\text { functioning state and } \\
\text { government } \\
\text { Creating a balance of } \\
\text { quality of life, economy, } \\
\text { social relations and the } \\
\text { ecological foundation of } \\
\text { society }\end{array}$ & $\begin{array}{l}\text { Awareness and under- } \\
\text { standing of societal } \\
\text { needs } \\
\text { Increase welfare and } \\
\text { well-being. } \\
\text { Create an attractive, } \\
\text { diverse, safe, healthy and } \\
\text { just world, with clean air, } \\
\text { water, soil and energy }\end{array}$ \\
\hline
\end{tabular}




\begin{tabular}{|c|c|c|c|}
\hline & EU SDS & NL SDS & PL SDS \\
\hline Resource use & $\begin{array}{l}\text { Sustainable consumption } \\
\text { and production patterns } \\
\text { Environmental protec- } \\
\text { tion } \\
\text { Polluters pay principle }\end{array}$ & $\begin{array}{l}\text { Products and production } \\
\text { systems designed to fulfil } \\
\text { valuable functions, also } \\
\text { after their life: a lifecycle- } \\
\text { society (C2C) }\end{array}$ & $\begin{array}{l}\text { A world that saves en- } \\
\text { ergy, and uses the re- } \\
\text { sources of the Earth } \\
\text { efficiently and in the long } \\
\text { term } \\
\text { C2C: make sure all mate- } \\
\text { rials used are clean and } \\
\text { re-usable after their life } \\
\text { cycle }\end{array}$ \\
\hline Future & $\begin{array}{l}\text { A long-term perspective, } \\
\text { solidarity within and } \\
\text { between generations }\end{array}$ & $\begin{array}{l}\text { Building a future } \\
\text { Taking into account long- } \\
\text { term developments and the } \\
\text { consequences of our ac- } \\
\text { tions on them } \\
\text { Here and now in relation to } \\
\text { the future }\end{array}$ & Forward-looking \\
\hline $\begin{array}{l}\text { Impact else- } \\
\text { where }\end{array}$ & $\begin{array}{l}\text { Meeting the interna- } \\
\text { tional responsibilities }\end{array}$ & $\begin{array}{l}\text { The Netherlands in relation } \\
\text { to the world }\end{array}$ & $\begin{array}{l}\text { Take the consequences } \\
\text { of our actions elsewhere } \\
\text { into account }\end{array}$ \\
\hline Innovation & $\begin{array}{l}\text { Tap the ecological and } \\
\text { social innovation poten- } \\
\text { tial of the economy. }\end{array}$ & Capacity for innovation & $\begin{array}{l}\text { SD requires innovation } \\
\text { SD goes hand in hand } \\
\text { with creativity and an- } \\
\text { ticipate and use new } \\
\text { opportunities }\end{array}$ \\
\hline Uncertainty & $\begin{array}{l}\text { Precautionary principle } \\
\text { Use best available } \\
\text { knowledge }\end{array}$ & & $\begin{array}{l}\text { Learning how to deal } \\
\text { with uncertainty }\end{array}$ \\
\hline
\end{tabular}

The fact that these common issues can be found in each policy is not surprising as they are recommended themes for sustainable development strategies (Lafferty, 2004; UNDESA, 2001). Sustainable development is understood to include elements of protection of natural support systems and intra- and intergenerational equity to counter the failure of current unsustainable systems (Lafferty, 2004). However, these issues do not represent a checklist yet. A checklist should contain questions people can ask to assess the policy (or plan they have) or the action they want to take. Therefore, for each theme questions have been formulated to help assess a policy or action, based on the principles listed above:

\section{Integrated approach and coherence}

- Is the policy /action coherent with the overall vision, or at least, does it not obstruct the overall vision?

- Is the policy/action in coherence with other policies/actions, i.e. does it link horizontally, vertically, as well as across scale levels?

- Does the policy /action have side-effects? 
- Is information from other domains useful for this policy /action? Consider the social, economical and environmental sub-systems

Quality of society

- Does the policy /action contribute to, or at least not reduce, the quality of society (social equity, social cohesion, acceptable levels of economic prosperity, social quality, mutual trust, social participation, open and democratic, ecological foundation) and fundamental rights of citizens?

- Are the right parties participating?

Resource use

- What (natural, non renewable) resources are needed for the policy /action? Are these resources necessary? Can these resources be used more efficiently?

- Does the policy/action/decision reduce biodiversity in any way, or does it contribute to creating new opportunities for species?

- Does this policy /action involve additional consumption of energy or scarce resources?

- Does the production method proposed have negative effects on human health or the environment?

- Does this policy /action ensure that polluters pay for their pollution?

- Can the resources be re-used after their life?

Future

- How does the policy /action influence future generations and ecosystems?

- How does the policy/action relate to long-term developments (e.g. Climate change)

Impact (elsewhere)

- What are the positive and negative impacts of this policy/action? (costs (monetary and non-monetary) vs. benefits)?

- Does the policy /action have impact elsewhere?

- Is the policy/action harming international responsibilities?

Innovation

- Does the policy/action involve innovative technology or behaviour?

- Can the method used be used elsewhere?

- Does the policy/action enhance innovative capacity?

Uncertainty

- What is the level of uncertainty of the answers? Is there need for the precautionary principle?

- Is this policy /action based on comprehensive and reliable analysis?

- Is the knowledge we are using for this policy /action the best we have?

These questions address both the intended objectives of a policy /action, as well as the unintended side-effects and interactions with other policy/decisions/actions. 
They should also identify who is affected by the impacts and when. Options that would be beneficial for society as a whole may have positive and negative impacts that are spread unevenly across society and over time (EU, 2009c).

Giving answers to these questions and making the answers available and thus explain the reasoning behind the actions, decisions and policies will contribute to transparency and openness, which are important ingredients of sustainable action. One could of course ask whether this list does not resemble questions that can be found in an impact assessment. Currently, the European Commission undertakes impact assessments for all major policy proposals to assess whether these are consistent with better regulation and sustainability principles (EU, 2009e). A first difference with the approach proposed here occurs immediately: The EU conducts an assessment for major policy proposals, whereas it is proposed here to formulate questions that can be used at various levels of action. Apart from this "it normally takes more than 12 months to produce an IA" (EU, 2009c) which is not workable in day to day decision-making and planning.

The EU Impact Assessment guidelines (2009c) say that "Impact assessment is a set of logical steps to be followed when you prepare policy proposals. It is a process that prepares evidence for political decision-makers on the advantages and disadvantages of possible policy options by assessing their potential impacts." Furthermore its says that "All policy-decisions should be based on sound analysis supported by the best data available." The IA guidelines address issues of policy coherence, policy quality and transparency and openness as requested by the 2001 white paper on governance (EU, 2001). Content-wise the impact assessment guidelines address sustainable development by means of elaborate lists of questions. Obviously this will lead to more detailed and thorough assessment of impacts than the checklist proposed here. However, the results are available only after a long time period and for many decisions or actions this time period is too long. In addition, an IA is a complex instrument to use which might restrict its usefulness at the provincial level. In the following examples a desk test of the checklist has been conducted on a proposed action and on an existing policy.

\subsubsection{Examples}

Let us put the proposed list of criteria to the test. This pilot should be seen as an intellectual exercise to investigate the possible usefulness of the list of criteria. Two examples are discussed in the following. The first example falls into the category "action" and deals with the imaginary wish to renovate the roof of a private house in order to prevent leakage of rainwater and loss of energy for heating. The second one deals with the category "policy" and is about the provincial policy on tourist mobility in the Heuvelland tourist area. 


\section{Example 1: Roof renovation of a private house}

\begin{tabular}{|c|c|}
\hline $\begin{array}{l}\text { Integrated approach and } \\
\text { coherence }\end{array}$ & $\begin{array}{l}\text { For a citizen it would be unclear to which overall goal one should refer } \\
\text { to. Should it be personal goals? Or should it be provincial or national } \\
\text { goals? If so, then what are these? Let us assume that the provincial } \\
\text { long term goal is meant. A roof renovation contributes to an improved } \\
\text { quality of the living environment because of less } \mathrm{CO}_{2} \text { emissions, less } \\
\text { energy consumption. It might also involve innovations and it keeps the } \\
\text { roofers, as a part of the local economy, in a job. } \\
\text { As a house owner it will be difficult to see coherence with policies and } \\
\text { actions. Probably with provincial or national renovation rules. } \\
\text { For a citizen it will be difficult to decide about side-effects }\end{array}$ \\
\hline Quality of society & $\begin{array}{l}\text { Because of reduced energy consumption there will be less air pollution } \\
\text { and better local air quality, and therefore no detrimental effects on } \\
\text { quality of society } \\
\text { The stakeholders involved are the household, the neighbours and the } \\
\text { roofers. }\end{array}$ \\
\hline Resource use & $\begin{array}{l}\text { We should reuse what can be reused. New materials (tiles, wood, } \\
\text { insulation) should be mined/managed/produced with care for the } \\
\text { environment and health. New materials should be recyclable } \\
\text { To avoid negative effects on human health or the environment new } \\
\text { materials (tiles, wood, insulation) should be } \\
\text { mined/managed/produced with care for the environment and health. } \\
\text { New materials should be recyclable. } \\
\text { The resources should be used efficiently, and produced with care for } \\
\text { biodiversity. Around the house, materials should be put on paved } \\
\text { areas in order not to endanger biodiversity around the house. } \\
\text { Because it is unknown where the materials come from it is unclear if } \\
\text { the polluter pays. }\end{array}$ \\
\hline Future & $\begin{array}{l}\text { The roof renovation is beneficial for the direct living environment. } \\
\text { Also, the natural gas reserves will be exhausted at a later stage. But } \\
\text { some questions arise: what will happen to the waste of the renova- } \\
\text { tion? Will there be recycling of materials? Which new materials will be } \\
\text { used? What impacts does their production or mining have on the } \\
\text { future? How will they be recycled later? }\end{array}$ \\
\hline Impact elsewhere & $\begin{array}{l}\text { Mining and production elsewhere can be harmful. Is this the case? } \\
\text { What happens to waste? Is it transported to elsewhere? } \\
\text { Probably extra resources will be needed for the renovation, but the } \\
\text { energy consumption of the house will be reduced. How does this } \\
\text { compare? } \\
\text { Very difficult to compare negative and positive impacts and to bring } \\
\text { the costs of resource mining or waste management into the calcula- } \\
\text { tions. We can however, calculate improved insulation capacity and the } \\
\text { reduction in energy consumption, as well as the costs of the roofers } \\
\text { and materials. }\end{array}$ \\
\hline Innovation & $\begin{array}{l}\text { Can the roof renovation be combined with other innovations? Who } \\
\text { would possess extra, roof-related knowledge? Probably topics such as } \\
\text { solar power for electricity and heating, rainwater harvesting, bio- } \\
\text { insulation should be taken into account, which means that more } \\
\text { professionals need to be involved than the roofers mentioned under }\end{array}$ \\
\hline
\end{tabular}




"stakeholders".
This approach for roof renovation could be copied elsewhere.
At this moment a lot of questions regarding information exist: we need
information about recycling, waste management, new materials,
positive and negative impacts (mining/management/production/fossil
fuels/recyclability). Should this roof renovation continue, regardless of
all the questions?

This assessment addresses issues of innovation, information needs, involvement of stakeholders, coherence, resource use, the future and a spatial component. It is surprising how rich the checklist is regarding topics covered. It was surprising to see that with a little extra thinking it is clear that many more stakeholders should be involved for a meaningful roof renovation. Another interesting outcome is the number of questions to which there are no answers. This checklist needs to be tested more thoroughly, but it seems that the question about the overall vision is difficult to answer for citizens. This would mean that more guidance is needed for citizens on this issue. Also, a lot of information apparently does not exist yet.

\section{Example 2: Tourist mobility in the Heuvelland tourist area}

(Heuvelland samen natuurlijk bereikbaar (Province of Limburg, 2005b))

Integrated approach and
coherence
pal infrastructural projects. What about the provincial spatial plan
(POL)? It is not mentioned in the policy.
This policy was created before the current coalition period with its
goal for 2007-2011. However, in principle an overall goal should be
somewhat longer-term than just 4 years. This policy contributes
mainly to a high quality of the living environment as well as to improv-
ing economic potential. But it is not clear to which overall goal the
policy contributes.
Improving accessibility and liveability for visitors and inhabitants of
the Heuvelland. Safer roads, less noise disturbance, more space for
quiet-loving tourists contribute to quality of society.
Stakeholders involved in the policy are Province, gewest, police,
tourist bureaus, hotels/restaurants, inhabitants, farmers, road con-
structors, staatsbosbeheer (nature and forestry department), shop-
keepers, public transport organisations.
We should reuse what can be reused. New materials (tar, cement,
wood) should be mined/managed/produced with care for the envi-
ronment and health. New materials should be recyclable.
Probably extra resources will be needed for the infrastructural pro-
jects and the parking places. Maybe new buses as well. But the quality
of life and the flora and fauna will probably benefit. How does this
compare?
New materials (tar, cement, wood) should be
mined/managed/produced with care for the environment and health.
New materials should be recyclable.
Resource use




Vulnerable nature areas will get more space and quiet because roads
will be closed. However, they might be threatened by more walking
tourists. Furthermore, biodiversity at infrastructural sites or parking
sites might be endangered. For these projects, resources should be
used efficiently, and produced with care for biodiversity.
It does not say in the document to what extent polluters pay. Does
the province have a policy about the pollution by third parties, and
others involved in the production chain needed for the infrastructural
projects?
Improved air quality and more space for nature are beneficial to the
quality of the environment. But what will be the effect of the persis-
tent trend of a decreasing population on mobility needs? What will be
the effect of the expected increase in tourism on nature and mobility?
Did the policy take this into account?
The resources to be used for infrastructural projects and the waste
that accompanies these projects might have an impact elsewhere
This is not a specific innovation or technology project. However, the
knowledge gained on stakeholder processes and defining which roads
are superfluous and setting up a comprehensive public transport with
concepts such as green bus stops (bus stop close to the start of hiking
routes) and demand dependent transport (CVV) could be useful for
other projects.
The policy is pretty transparent, but as is shown above, a lot of ques-
tions remain unanswered. There is no clear description of trade-offs
and costs-benefits.
Innovation

This assessment shows again problems in answering questions related to the coherence with the overall goals, because these are not very explicit. However, the proposal mentions related policies and goals. Again a lot of unanswered questions occurred. An important question is if the decreasing population has been taken into account. Also, it is unknown if the resources needed have been produced and used with care for human and environment. The impact of the actions resulting from the policy elsewhere are not discussed. Trade-offs are not discussed. There is definitely room for improvement in this policy. The sustainable development checklist can help to enrich the policy, while keeping it targeted on improved mobility for a specific area.

In general, the criteria designed in this chapter raise many additional questions to which at present there are no easy answers. If sustainable development would be used as a guiding principle in all actions, this type of information becomes clearly very important. For the time being the lack of data is problematic. However, once the need for this information grows because sustainable development is used as a guiding principle throughout society, efforts will be set up to provide the information either directly or with proxy indicators. 
It is however important to mention that this is a first attempt at such a list. It is to be seen as a translation of sustainability characteristics into criteria we can really use in order to work towards the desired future in a sustainable way. The examples show that sustainable development can be used as a guiding principle for so-called non-sustainability issues because even non-sustainability issues have a sustainability component. The current practice of making specific sustainable development policy, with key challenges and sustainable development projects places these in a sustainability niche. New avenues for operationalisation could be opened up if sustainable development is used as a guiding principle, with criteria that are applied to every policy and action.

The role of the province could be one of goal-setting and visioning. The province could use the checklist to set an example and to further develop it. They could then ensure it is being used at lower scale levels.

\subsection{Conclusion}

Policy regarding sustainable development has been developed at various scale levels, with specific sustainable development goals, actions and projects. From a historical perspective sustainable development has been interpreted as environment until the late eighties of the $20^{\text {th }}$ century. Only then the integrated vision and the link between environment and social issues, and economic development became an issue on the international agenda. But it took long for this approach to trickle down to the provincial level. In the province of Limburg the first sustainable development programme with budget and a responsible deputy occurred in 2005 . Still, sustainable development programmes often reside within a governmental department responsible for environmental protection.

When applying the framework for governance for sustainable development (ZeijlRozema van et al., 2008) we see that all three policies - EU, Dutch, Limburg - show no clear link to the overall vision, do not clarify how key themes have been chosen and proceed to focus mainly on the key themes, rather than focusing on achieving the overall vision. Furthermore, a vision on the desired future and how the SDS contributes to it, is lacking. Sustainable development is broken down into specific actions, but in monitoring requirements the contribution of the parts to the whole is not mentioned. The different scale levels are not linked. The policies are placed in a 'sustainability niche' by the type of icon projects they propose. All of this reduces the effectiveness of the policies to realise sustainable development. Although each policy mentions that sustainable development should be a crosscutting issue through all policy and action, this is not achieved. A possible way to do this would be to see sustainable development not as a goal in itself, but as a principle to guide all action, whether this is defence, safety or energy consumption. 
The concept of sustainable development itself is too broad and complex to be a good guide for basing actions and policy on. Therefore, as a first attempt a checklist for sustainable development has been developed. Key elements of this checklist are an integrated approach, the quality of society, future impacts, impact elsewhere, innovation, and dealing with uncertainty. This checklist is not as comprehensive as a full impact assessment, and does not replace the legally required impact assessments for large scale projects or major policies. It is intended as a checklist to help decisions and to create an integrated picture of the action or policy to be undertaken for achieving the overall long-term vision rather than having sustainable development policy for a limited number of key challenges and projects.

Sustainable development policy as it stands now contains barriers to the realisation of sustainable development. It seems viable to use sustainable development as a guiding principle for designing our plans and actions in order to realise our desired future. 
Annex 3.1: Analysis of three sustainable development strategies according to the framework for governance for sustainable development

\begin{tabular}{|c|c|c|c|}
\hline Criteria & $\mathrm{EU} \mathrm{SDS}^{9}$ & Dutch SDS $^{10}$ & Limburg SDS $^{11}$ \\
\hline \multicolumn{4}{|l|}{ Perspective on SD: } \\
\hline focus & Well-being p2 & Well-being p2, triple $P(p 4)$ & $\begin{array}{l}\text { Well-being (PPP, time, } \\
\text { place) p9 }\end{array}$ \\
\hline use of goals & $\begin{array}{l}7 \text { qualitative key challenges, } \\
\text { with partly quantitative } \\
\text { results p7-21 } \\
\text { Main challenge is to gradu- } \\
\text { ally change unsustainable } \\
\text { consumption and produc- } \\
\text { tion patterns and the non- } \\
\text { integrated approach to } \\
\text { policy-making (p2) }\end{array}$ & $\begin{array}{l}3 \text { tracks, one of which with } \\
6 \text { themes. cradle to cradle } \\
\text { concept challenges creativ- } \\
\text { ity and innovation and will } \\
\text { be used in implementation } \\
\text { of sustainable development } \\
\text { p4 } \\
\text { Goals partly quantitative, } \\
\text { partly qualitative p5-10 }\end{array}$ & $\begin{array}{l}6 \text { Qualitative goals with } \\
\text { partly quantitative results } \\
\text { (“doelstelling per speer- } \\
\text { punt" p 22-30) } \\
\text { No blue-print but multiple } \\
\text { solutions exist p16 }\end{array}$ \\
\hline $\begin{array}{l}\text { supporting basis } \\
\text { to legitimise goals }\end{array}$ & $\begin{array}{l}\text { Review process, various EU } \\
\text { institutions, but basically } \\
\text { the reason for choosing } \\
\text { these key challenges is } \\
\text { unclear }\end{array}$ & $\begin{array}{l}\text { The peer review of the } \\
\text { Dutch SDS, the } 2^{\text {nd }} \text { sustain- } \\
\text { ability outlook of MNP (p 2- } \\
\text { 3). It says on p4 that the } 6 \\
\text { themes were chosen be- } \\
\text { cause they deal with the } \\
\text { physical environment, and } \\
\text { provide economical oppor- } \\
\text { tunities and include an } \\
\text { element of global solidarity. } \\
\text { Themes from the overall } \\
\text { policy programme were } \\
\text { chosen that are societally } \\
\text { relevant, and provide } \\
\text { opportunities for increasing } \\
\text { coherence between devel- } \\
\text { opment cooperation, } \\
\text { innovation and environ- } \\
\text { mental policy and thus to } \\
\text { contribute to the future of } \\
\text { the Netherlands.p4 How- } \\
\text { ever, unclear why these } \\
\text { two tracks and } 6 \text { themes } \\
\text { were chosen and not oth- } \\
\text { ers. }\end{array}$ & $\begin{array}{l}\text { Unclear what the support- } \\
\text { ing basis is. Unclear why } \\
\text { the themes were chosen }\end{array}$ \\
\hline
\end{tabular}

\footnotetext{
${ }^{9}$ EU, 2006. Review of the EU Sustainable Development Strategy (EU SDS) - Renewed Strategy. pp. 129. Council of the European Union 10917/06.

${ }^{10}$ VROM, 2008. Kabinetsbrede aanpak duurzame ontwikkeling. pp. 1-11.VROM DGM/BREM2008050615.

${ }^{11}$ Province of Limburg, 2009a. Beleidskader Duurzame Ontwikkeling/Cradle to Cradle 2008-2011. pp. 141.Afd. Milieu en Duurzame Ontwikkeling
} 


\begin{tabular}{|c|c|c|c|}
\hline Criteria & $\mathrm{EU} \mathrm{SDS}^{9}$ & Dutch SDS ${ }^{10}$ & Limburg SDS ${ }^{11}$ \\
\hline \multicolumn{4}{|c|}{ Mode of governance: } \\
\hline $\begin{array}{l}\text { key-decision- } \\
\text { maker }\end{array}$ & $\begin{array}{l}\text { The review process was a } \\
\text { broad societal exercise (EU, } \\
2005 a \text { ), various EU institu- } \\
\text { tions have contributed. MSs } \\
\text { have to implement }\end{array}$ & $\begin{array}{l}\text { There is no mention of } \\
\text { involvement of societal } \\
\text { actors participating in } \\
\text { drawing up the SDS. } \\
\text { The cabinet has informed } \\
\text { the Parliament about the } \\
\text { SDS. } \\
\text { There are some interminis- } \\
\text { terial commissions working } \\
\text { on sustainable develop- } \\
\text { ment }\end{array}$ & $\begin{array}{l}\text { There is no mention of } \\
\text { involvement of societal } \\
\text { actors participating in } \\
\text { drawing up the SDS. It has } \\
\text { been endorsed by the } \\
\text { provincial parliament (p 5). }\end{array}$ \\
\hline $\begin{array}{l}\text { stakeholder } \\
\text { relations }\end{array}$ & $\begin{array}{l}\text { The SDS describes actions } \\
\text { to be taken by member } \\
\text { states, i.e. top-down. } \\
\text { However, the process of } \\
\text { coming to the SDS has been } \\
\text { participatory. P3 } \\
\text { Involvement of society, } \\
\text { business and social partners } \\
\text { is seen as important. P } 5\end{array}$ & $\begin{array}{l}\text { Societal dialogue about } \\
\text { sustainable development is } \\
\text { important, but is also the } \\
\text { most vague track. On p10 it } \\
\text { says that in the societal } \\
\text { debate government is the } \\
\text { initiating and if necessary } \\
\text { the directing force. It can } \\
\text { facilitate other societal } \\
\text { partners. } \\
\text { On p2 it is mentioned that } \\
\text { the cabinet will safeguard } \\
\text { the progress and imple- } \\
\text { mentation of sustainable } \\
\text { development }\end{array}$ & $\begin{array}{l}\text { Province is but one of the } \\
\text { players, other actors need } \\
\text { to participate from their } \\
\text { own accord. Province } \\
\text { takes the lead in connect- } \\
\text { ing, creating an enabling } \\
\text { environment, but also } \\
\text { actively participates in } \\
\text { activities (p33) }\end{array}$ \\
\hline $\begin{array}{l}\text { favoured steering } \\
\text { approach. }\end{array}$ & $\begin{array}{l}\text { financial and economic } \\
\text { instruments are to be used, } \\
\text { as well as communication, } \\
\text { mobilisation of actors p24- } \\
25\end{array}$ & $\begin{array}{l}\text { Not very explicit. } \\
\text { Societal debate, direct, } \\
\text { facilitate, take initiative, } \\
\text { safeguarding }\end{array}$ & $\begin{array}{l}\text { Various roles are described } \\
\text { for the provincial govern- } \\
\text { ment p40-41: } \\
\text {-connect parties } \\
\text {-facilitate } \\
\text {-Stimulate } \\
\text {-raise awareness/ activate } \\
\text {-direct } \\
\text {-take initiative }\end{array}$ \\
\hline
\end{tabular}




\begin{tabular}{|c|c|c|c|}
\hline Criteria & EU SDS $^{9}$ & Dutch SDS ${ }^{10}$ & Limburg SDS $^{11}$ \\
\hline \multicolumn{4}{|c|}{ Expressions of governance for SD } \\
\hline $\begin{array}{l}\text { Sustainable } \\
\text { development goal }\end{array}$ & $\begin{array}{l}\text { sustainable development } \\
\text { means that the needs of } \\
\text { the present generation } \\
\text { should be met without } \\
\text { compromising the ability of } \\
\text { future generations to meet } \\
\text { their own needs. It is about } \\
\text { safeguarding the earth's } \\
\text { capacity to support life and } \\
\text { is based on the principles of } \\
\text { democracy, gender equal- } \\
\text { ity, solidarity, the rule of } \\
\text { law and respect for funda- } \\
\text { mental rights, including } \\
\text { freedom and equal oppor- } \\
\text { tunities. It aims at the } \\
\text { continuous improvement of } \\
\text { the quality of life and well- } \\
\text { being on earth for present } \\
\text { and future generations. } \\
\text { Main challenge is to gradu- } \\
\text { ally change unsustainable } \\
\text { consumption and produc- } \\
\text { tion patterns and the non- } \\
\text { integrated approach to } \\
\text { policy-making (p2) } \\
\text { A multitude of actors was } \\
\text { invited to comment on the } \\
\text { proposed topics during the } \\
\text { review process, but it is not } \\
\text { clear from (EU, 2005a) what } \\
\text { the impact of their com- } \\
\text { ments was on the final } \\
\text { selection of topics and the } \\
\text { definition of goals. }\end{array}$ & $\begin{array}{l}\text { Sustainable development is } \\
\text { about balancing quality of } \\
\text { life, economy, social rela- } \\
\text { tions and the ecological } \\
\text { basis of society. It is about } \\
\text { now and here, in relation to } \\
\text { the future, and about the } \\
\text { Netherlands in relation to } \\
\text { the world. Emphasis is on } \\
\text { growth and development } \\
\text { combined with addressing } \\
\text { and preventing problems. It } \\
\text { is about creating value, } \\
\text { about development of } \\
\text { people, communities and } \\
\text { the world, about equal } \\
\text { opportunities and about } \\
\text { building the future. sustain- } \\
\text { able development asks for } \\
\text { ain integrated effort of } \\
\text { economy, social develop- } \\
\text { ments and taking care of } \\
\text { the earth. It is also about } \\
\text { developments in the long- } \\
\text { term and the consequences } \\
\text { of our actions. Many socie- } \\
\text { tal issues require a sustain- } \\
\text { able approach. (p2) }\end{array}$ & $\begin{array}{l}\text { Sustainable development } \\
\text { is about balancing and } \\
\text { interrelating the stakes } \\
\text { within the social, nature } \\
\text { and environment, and } \\
\text { economical domain. Also it } \\
\text { means taking care of de } \\
\text { consequences of our } \\
\text { actions elsewhere in the } \\
\text { world and for the long- } \\
\text { term (p9) The goal is to } \\
\text { come to new solutions and } \\
\text { developments that en- } \\
\text { hance and enlarge wellbe- } \\
\text { ing and welfare (p10) } \\
\text { There is no mention in the } \\
\text { document about that the } \\
\text { goals or the key challenges } \\
\text { are defined by a multitude } \\
\text { of actors and that they } \\
\text { agree on the diversity of } \\
\text { goals. As mentioned } \\
\text { above, the document was } \\
\text { developed up by the } \\
\text { provincial government. No } \\
\text { mention of stakeholder } \\
\text { dialogues can be found. }\end{array}$ \\
\hline
\end{tabular}




\begin{tabular}{|c|c|c|c|}
\hline Criteria & $\mathrm{EU} \mathrm{SDS}^{9}$ & Dutch SDS ${ }^{10}$ & Limburg SDS $^{11}$ \\
\hline $\begin{array}{l}\text { implementation } \\
\text { strategy }\end{array}$ & $\begin{array}{l}\text { Operational objectives and } \\
\text { targets do not describe the } \\
\text { path towards implementa- } \\
\text { tion. Discretion for imple- } \\
\text { mentation with MSs. } \\
\text { The EUSDS sets out that } \\
\text { sustainable development is } \\
\text { to be integrated into policy- } \\
\text { making at all levels (p6) }\end{array}$ & $\begin{array}{l}\text { Some operational targets } \\
\text { are quantified, others are } \\
\text { qualitative. } \\
\text { The cabinet has decided on } \\
\text { the actions to be taken. For } \\
\text { some goals there is a lot of } \\
\text { discretion for implementa- } \\
\text { tion, for others not. } \\
\text { Sustainable development is } \\
\text { a cross-cutting topic in all } \\
\text { government policy p2 }\end{array}$ & $\begin{array}{l}\text { Sustainable development } \\
\text { is not a policy field, but a } \\
\text { way of working that should } \\
\text { become mainstream.p17 } \\
\text { How the goals should be } \\
\text { achieved is not defined. } \\
\text { Some goals are clearly } \\
\text { quantified (50\% of provin- } \\
\text { cial procurement should } \\
\text { be conform criteria for } \\
\text { sustainable procurement) } \\
\text { and leave little room for } \\
\text { discretion. Others are } \\
\text { more general and leave } \\
\text { more room for discretion. } \\
\text { p22-32 } \\
\text { It is stated that sustainable } \\
\text { development needs a new } \\
\text { way of thinking and doing. } \\
\text { Innovations, investments } \\
\text { and time are necessary } \\
\text { (p33) } \\
\text { However, in general the } \\
\text { province has decided on } \\
\text { which actions to be taken } \\
\text { and which roles it will play. } \\
\text { P 22-32 }\end{array}$ \\
\hline commitment & $\begin{array}{l}\text { Commitment to sustainable } \\
\text { development is very un- } \\
\text { clear }\end{array}$ & $\begin{array}{l}\text { Commitment to sustainable } \\
\text { development is unclear, but } \\
\text { similar to the situation in } \\
\text { Limburg, many citizens } \\
\text { think sustainable develop- } \\
\text { ment is important but } \\
\text { government should take } \\
\text { the lead }\end{array}$ & $\begin{array}{l}\text { Commitment to sustain- } \\
\text { able development is very } \\
\text { unclear, although the } \\
\text { survey among the Limburg } \\
\text { population shows that } \\
78 \% \text { of the population } \\
\text { thinks sustainable. devel- } \\
\text { opment is important. } \\
\text { However, many people } \\
\text { believe that government } \\
\text { should take the lead.(94\%, } \\
\text { see chapter 4) }\end{array}$ \\
\hline $\begin{array}{l}\text { acknowledgemen } \\
\text { of uncertainty }\end{array}$ & $\begin{array}{l}\text { Where there is scientific } \\
\text { uncertainty implement } \\
\text { evaluation procedures and } \\
\text { take appropriate preventive } \\
\text { action in order to avoid } \\
\text { damage to human health or } \\
\text { the environment (precau- } \\
\text { tionary principle, p5) }\end{array}$ & $\begin{array}{l}\text { No mention about uncer- } \\
\text { tainty }\end{array}$ & $\begin{array}{l}\text { It is mentioned that we } \\
\text { have to learn to deal with } \\
\text { uncertainties p } 10\end{array}$ \\
\hline
\end{tabular}




\begin{tabular}{|c|c|c|c|}
\hline Criteria & EU SDS $^{9}$ & Dutch SDS ${ }^{10}$ & Limburg SDS $^{11}$ \\
\hline Focus & $\begin{array}{l}\text { The review process shows } \\
\text { the goal setting process was } \\
\text { important. The document } \\
\text { itself shows that achieving } \\
\text { the goals is important too. } \\
\text { Monitoring requirements } \\
\text { have a focus on progress } \\
\text { made and serve as a basis } \\
\text { for adjusting the SDS. }\end{array}$ & $\begin{array}{l}\text { Working from strengths, } \\
\text { with a limited amount of } \\
\text { quantified objectives and } \\
\text { away from the average is } \\
\text { the starting point of the SDS } \\
\text { P4. } \\
\text { Triple P touches upon all } \\
\text { aspects of society and is } \\
\text { therefore a general frame- } \\
\text { work for thinking that } \\
\text { inspires and directs. P4 } \\
\text { Especially track } 1 \text { and } 2 \\
\text { have a focus on achieving } \\
\text { the goals. There is no } \\
\text { mention of discussing the } \\
\text { goals, and going through a } \\
\text { process of adjusting the } \\
\text { goals to new insights or } \\
\text { societal needs. }\end{array}$ & $\begin{array}{l}\text { The process of main- } \\
\text { streaming a sustainable } \\
\text { way of work is important. } \\
\text { P17 but achieving the } \\
\text { goals is important too. } \\
\text { P22-32 There is no men- } \\
\text { tion of discussing the } \\
\text { goals, and going through a } \\
\text { process of adjusting the } \\
\text { goals to new insights or } \\
\text { societal needs. }\end{array}$ \\
\hline $\begin{array}{l}\text { role for technical } \\
\text { fixes }\end{array}$ & $\begin{array}{l}\text { Goals are defined, ways for } \\
\text { implementation are not } \\
\text { defined. P7-22 Therefore } \\
\text { no emphasis on certain } \\
\text { technical solutions or on } \\
\text { behavioural change as } \\
\text { preferred ways of achieving } \\
\text { the goals }\end{array}$ & $\begin{array}{l}\text { Some focus on technologi- } \\
\text { cal developments and } \\
\text { innovation, but also atten- } \\
\text { tion to societal awareness } \\
\text { and dialogue }\end{array}$ & $\begin{array}{l}\text { Cradle to cradle as a } \\
\text { leading principle for design } \\
\text { and production processes } \\
\text { is important }\end{array}$ \\
\hline $\begin{array}{l}\text { monitoring and } \\
\text { evaluation ques- } \\
\text { tions }\end{array}$ & $\begin{array}{l}\text { Monitoring of progress on } \\
\text { key challenges will be done } \\
\text { on a two-yearly basis, } \\
\text { results will be used to } \\
\text { review progress and priori- } \\
\text { ties p27 }\end{array}$ & $\begin{array}{l}\text { Monitor for sustainable } \\
\text { development developed to } \\
\text { show how sustainable the } \\
\text { Netherlands is. Yearly } \\
\text { update of monitor and a } \\
\text { yearly progress report to } \\
\text { Parliament. }\end{array}$ & $\begin{array}{l}\text { Monitoring and evaluation } \\
\text { of achievement of the } \\
\text { results will be done on a } \\
\text { yearly basis }\end{array}$ \\
\hline
\end{tabular}




\section{$4 \quad$ Sustainable development and the Limburg population}

Implementation of sustainable development requires cooperation of actors of state, market and civil society (Zeijl-Rozema van et al., 2008). It is known that citizens think that government should take the lead in sustainable development and show by example what should be done (iNSnet, 2006; 2007; 2008). But the government cannot realise sustainable development alone. It is assumed by the author that one reason why implementation fails is because people are unfamiliar with the concept, the concept is too abstract and is not well understood. However, in this chapter we also assume that people do take actions that fall within the context of sustainable development without being called that. Therefore, a survey was conducted in Limburg to find answers to these assumptions. This chapter investigates the barriers to implementation of sustainable development that exist in the current understanding of, and action towards, sustainable development of the Limburg population.

\subsection{What, why, who and how?}

Sustainable development is a very complex and abstract concept. If policy on sustainable development is not properly communicated in such a way that people can understand what is meant, it will be very difficult to implement. That is why an investigation was done among the population of Limburg, to find out what people know about sustainable development, and what actions they take. This was done by means of an internet survey consisting of 28 questions. The majority of questions was multiple choice with a few open questions. The following hypotheses were formulated:

- Sustainable development is not well known: a gap in implementation could be explained by a limited understanding of what it is that should be done. From personal experience we know that for a lot of people the concept is not well known and very abstract.

- Sustainable development is understood mainly as environment: If we look at the Dutch history in the field of sustainable development we see that it has been approached from an environmental angle. In the previous chapter we saw that a criticism of the peer review conducted in 2007 of the Dutch sustainable development strategy was that it was too much focused on the environment (Zijst, 2006). Therefore, it would seem possible that at the level of the individual citizen sustainable development is also understood as environment 
- People show sustainable behaviour, but don't always call it that: If indeed people do not know what sustainable development entails, they will probably not call their behaviour and actions sustainable. However, it might well be that they do consider in their lives people, planet, profit, the future and impacts elsewhere. Therefore, a large portion of the questionnaire is devoted to finding out what people's considerations are for making a variety of decisions on shopping, mobility, repairing their house, going on holidays, etc.

Furthermore, people were asked who should take the lead in sustainable development and how that should be done. From previous surveys in the Netherlands (iNSnet, 2006; 2007; 2008) we know that most people think government should take the lead. But government can exist at many different levels and might use different instruments. Also other parties - market, research and education and civil society - might have a role to play. Questions were directed towards finding out answers to these issues.

All in all, 910 people out of 1281 have responded to the questionnaire, which is a response rate of $71 \%$. Among these 910 were 857 adults. This is a representative sample of the Limburg population (over 18 years) regarding gender, age distribution, level of education and spatial distribution in Limburg. It should be noted that in comparison to the Dutch average, the Limburg population is less prosperous, is decreasing, is older, has lower levels of education, has a lower life expectancy, higher unemployment rates and is more industrialised (Province of Limburg, 2006; 2009b).

53 respondents were youths in the age of 12-18 years. The reason for including these respondents was twofold: the future is in the hands of the young people of today. Their knowledge of sustainable development determines their future lifestyle, working habits and decisions. Secondly, a section of the questionnaire is devoted to schools and higher education establishments. Without the youths the answers would be somewhat limited. However, the youths are not a representative sample of Limburg.

The questionnaire was sent out via internet to a pool of respondents. The respondents receive a small bonus for participating. The ISO 2636212 certified internet research bureau Flycatcher conducted the questionnaire and the statistical analyses. The questions have been pre-tested by the author and by Flycatcher. For the statistical analyses a chi-square test was used. The Bonferroni method was used for correcting for multiple testing. A difference is called significant if there is statistical significance with a confidence of $95 \%$. In the statistical analysis some groups had to be clustered in order to obtain sample sizes that were big enough (>30 people).

\footnotetext{
${ }^{12}$ Quality certificate for internet market research panels
} 
After a first straight count of the results, results were clustered in order to get more meaningful groups, e.g. fighting child labour, social cohesion, poverty reduction and happiness were all grouped into a cluster social capital.

The following sections in this chapter deal with what people think about sustainable development, providing information on the first two hypotheses (sustainable development is not well known and is mainly interpreted as environment). Section 4.3 and 4.4 deal with behaviour and address the third hypothesis (people show sustainable behaviour but don't call it that). Questions about who should take the lead in sustainable development and how that should be done, are addressed in section 4.5 , followed by an overall conclusion and recommendations.

\subsection{What do people think about sustainable development?}

This section aims to find information to accept or reject the hypotheses regarding the concept of sustainable development:

- sustainable development is not well known

- sustainable development is mainly interpreted as environmental issues

People have been asked whether they are familiar with the concept of sustainable development, what issues they think of, what description fits best and how important sustainable development is for them. After the first few questions, a description was given for all respondents to ensure everyone had the same information, This description was available as an information button throughout the questionnaire.

\subsubsection{The concept of sustainable development}

$72 \%$ of the respondents is familiar with the concept of sustainable development. Men are significantly more familiar with it than women (76\% vs. $68 \%$ ) and people older than 60 years are more familiar with it than the working population (25-60). People with a higher education are significantly more familiar with sustainable development than lower and medium educated people.

$59 \%$ of the respondents thinks sustainable development is important, $20 \%$ thinks sustainable development in not important but not unimportant either, and $19 \%$ think it is very important. Only $2 \%$ of the respondents say sustainable development is not important (Fig. 4.1). 


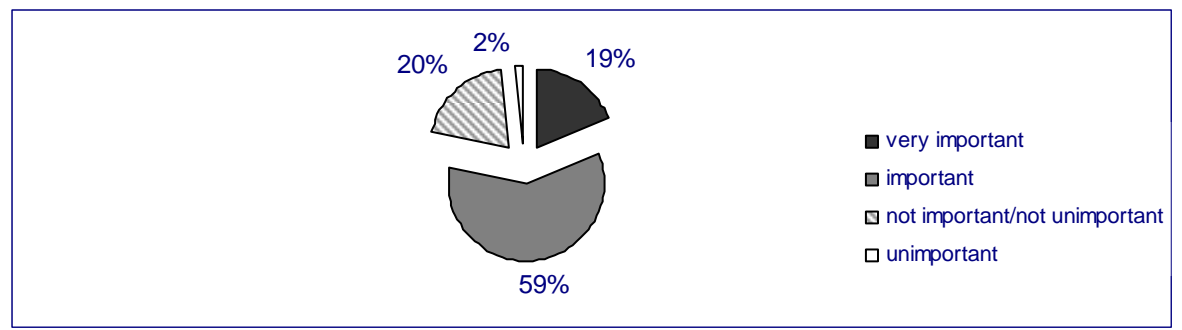

Figure 4.1: The importance of sustainable development

Those who are neutral towards sustainable development more often are younger than 60. Lower educated respondents more often are neutral than the higher educated respondents. Those who are familiar with sustainable development more often say sustainable development is important or very important than those who are unfamiliar. Those who are unfamiliar with sustainable development more often say it is neither important nor unimportant

The respondents were asked to identify a description that best fit their idea of sustainable development. It was expected that many people would choose the environment related option most, but contrary to expectations, they identified most with the description of sustainable development as a balanced development of environment, society and economy together (55\%). The next best scores were for "development towards a liveable future" (17\%) and "development or solution that lasts for a long time (12\%).

However, when confronted with a number of concrete topics that are all part of sustainable development, $99 \%$ of the respondents thought of environmental issues. Social issues were next, with $71 \%$. Issues related to the temporal perspective (short-term, future) came on the third place with $66 \%$, followed by innovation and technology with $51 \%$. Economy related issues came only on the fifth place, with $39 \%$. Spatial issues (here and elsewhere) and institutional issues came last (Fig. 4.2). 


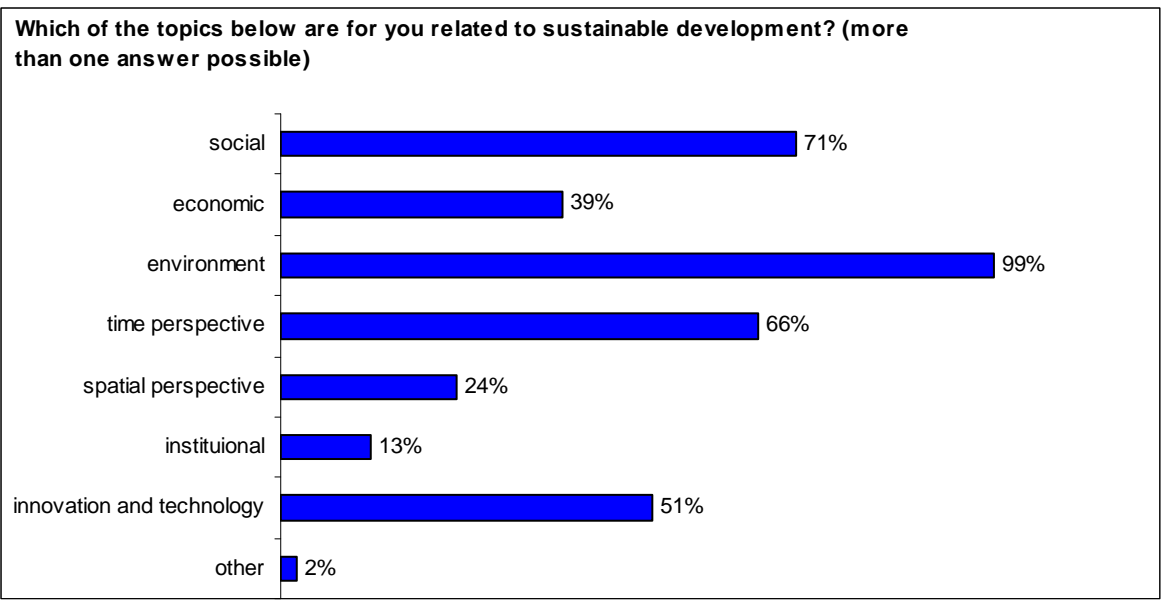

Figure 4.2: Topics related to sustainable development

Women identified significantly more social, temporal and spatial issues as belonging to sustainable development than men. Men however, thought more often of innovation and technology as belonging to sustainable development ( $56 \%$ vs. $47 \%$ ). Also, higher educated people thought so. People younger than 25 thought more often of time related issues than the group above 60 years of age. This latter group included more often institutional issues (quality of governance) into sustainable development than the other age groups.

\subsubsection{Environment or sustainable development?}

We have explored this interpretation of "sustainable development as environment" in more detail. Therefore, a part of the survey was devoted to identify people's environmental behaviour and their sustainable development behaviour. Three important observations can be made on the environmental behaviour (see table 4.1). Environmental practices seem to be done by many people, at home, at work and at school. Taking care of the environment is mainstream. Furthermore, those younger than 25 report less often about environmental measures taken than the older respondents. Therefore, it is important to specifically target them in any information campaign. Maybe they simply have fewer options because they live with their parents or caretakers. Or they might be unaware of the measures taken. Or they might be not interested. A last observation is that those who are familiar with the concept of sustainable development are more environmentally conscious. Therefore, it is important to provide more people with information about sustainable development. 
Table 4.1: Comparing the scores for environment at the home situation with work and school (more answers per person were possible). (>80\%, 60-80\%, 50-59\%, <50)

\begin{tabular}{llll}
\hline & Home & Work & School \\
\hline Separating waste & 96 & 81 & $72 \%$ \\
\hline Saving energy & 95 & 79 & $64 \%$ \\
\hline Saving heating & 91 & 68 & $57 \%$ \\
\hline A-label appliances & 89 & 66 & $62 \%$ \\
\hline Saving water & 83 & 58 & $58 \%$ \\
\hline No poison around premises & 60 & 54 & $67 \%$ \\
\hline Green energy & 67 & 50 & $63 \%$ \\
\hline Environmentally friendly use of detergents & 52 & 59 & $54 \%$ \\
\hline Sustainable building & 46 & 32 & $50 \%$
\end{tabular}

When we look at sustainable development issues (see table 4.2) we see that those who know more about sustainable development more often indicate they do social and environmental issues. But in general, what people do is not homogeneous. Some things are done a lot, some hardly. Spatial and temporal issues score relatively high. At home, at school and at work people think about the future of the world. But the results are not such that they show that people also think about a sustainable future. The results are lower and less homogeneous than for environmental behaviour. From this we can conclude that although environmental consciousness has become mainstream, sustainability consciousness is not yet a common thing. People mention that they have received information on sustainable development only to a limited extent. This might be one reason why people do not act sustainably.

An interesting issue that should be pointed out is that there is a large difference between the private sphere regarding supporting deprived people and the work and school sphere regarding employing minorities. Almost twice the amount of people agree to this for work and school than for the household situation. Employing minorities is official Dutch policy. Here we see an example were regulation does have an effect. This does not imply that every household should be obliged to give to the poor. In a way the Dutch tax paying system is already taking that function by providing facilities for the deprived. However, regulation could be beneficial in certain cases. 
Table 4.2: Comparing the scores for sustainable development at the home situation with work and school.

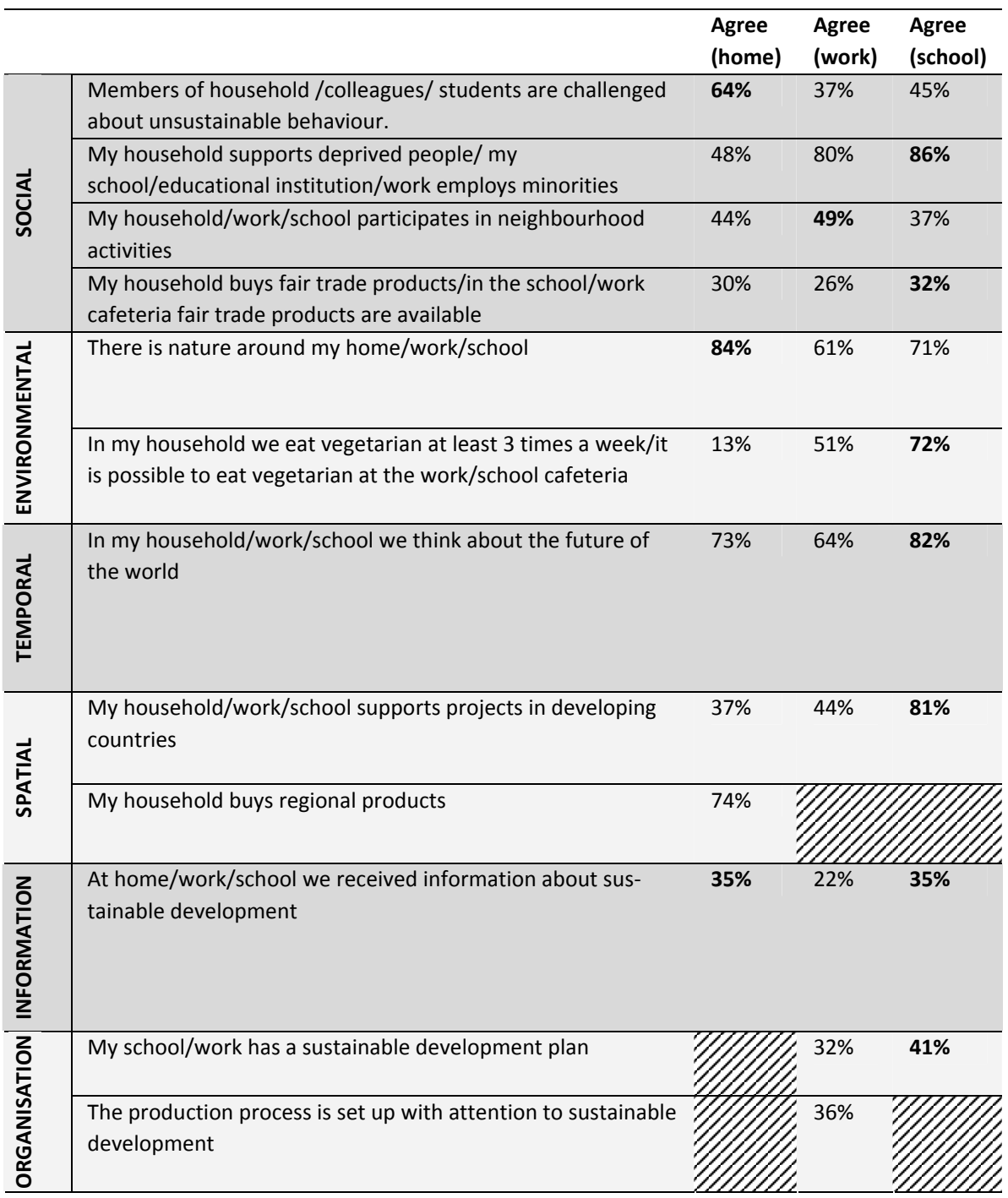

\subsubsection{Implications}

In conclusion, $72 \%$ of the people is familiar with sustainable development, $78 \%$ thinks sustainable development is important. Those who are familiar with sustainable development understand it as a balanced development of society, economy and the environment. However, when asked about concrete actions that are part of sustainable development, they mainly choose environmental issues. It should be noted that social and time related issues are mentioned often too. 
What does this mean for the hypotheses? The first hypothesis was that sustainable development was not well-known. $72 \%$ of the people is familiar with the concept and of those, $55 \%$ chooses the description of a balanced development of social, environmental and economic capital. From this we can conclude that sustainable development is relatively well-known and is understood in the right way. Regarding the second hypothesis that people understand sustainable development mainly as environment, we should conclude that at an abstract level they understand sustainable development in its notion of a balance between the domains. This would mean that the hypothesis can be rejected. However, in concrete terms, they prefer environmental issues, which confirms the hypothesis. This gives us an important lesson: the familiarity with sustainable development exists only at an abstract level. If we want people to become more sustainable they should be informed in concrete terms what that entails. At a concrete level environment is mainstream, but sustainable development not.

Some other important lessons that can be drawn from the analysis is that higher educated people are more familiar with sustainable development. Young people more often choose time related issues than older people. Economy related issues are on the fifth place, implying that economy is not seen as an important part of sustainable development. Lastly, men and women have other understanding of which issues belong to sustainable development.

In an information campaign all these elements should be included: provide concrete instead of abstract issues, with attention for gender, education and age related differences. Such a campaign should also make clear how the economy plays a role and is interconnected with ecology and society. This should entail information that provides concrete examples of what sustainable development can mean at home, at work and at school.

\subsection{How sustainable do people say they are?}

Because sustainable development is such a complex and abstract concept it is assumed that people might not recognise what they do as being sustainable. Therefore, a large part of the questionnaire was devoted to finding out which actions people carry out and whether the considerations that are at the basis of their decisions are related to sustainable development. The third hypothesis - People show sustainable behaviour, but don't always call it that - will be answered in this section and the next one.

Often there is a discrepancy between what people say they wish to do and actual behaviour. Therefore, we asked people how sustainable they are now (Fig. 4.3). Also the sustainability image of their work has been investigated. 
A majority of respondents either consciously chooses for a sustainable lifestyle and sustainable products $(40 \%)$ or says they choose for sustainability if it doesn't cost more or takes more effort (43\%). $10 \%$ say that they only choose for a sustainable lifestyle if others do it too and its usefulness has been demonstrated. $7 \%$ say that they are not at all concerned about a sustainable lifestyle and will need to be forced to adopt one.

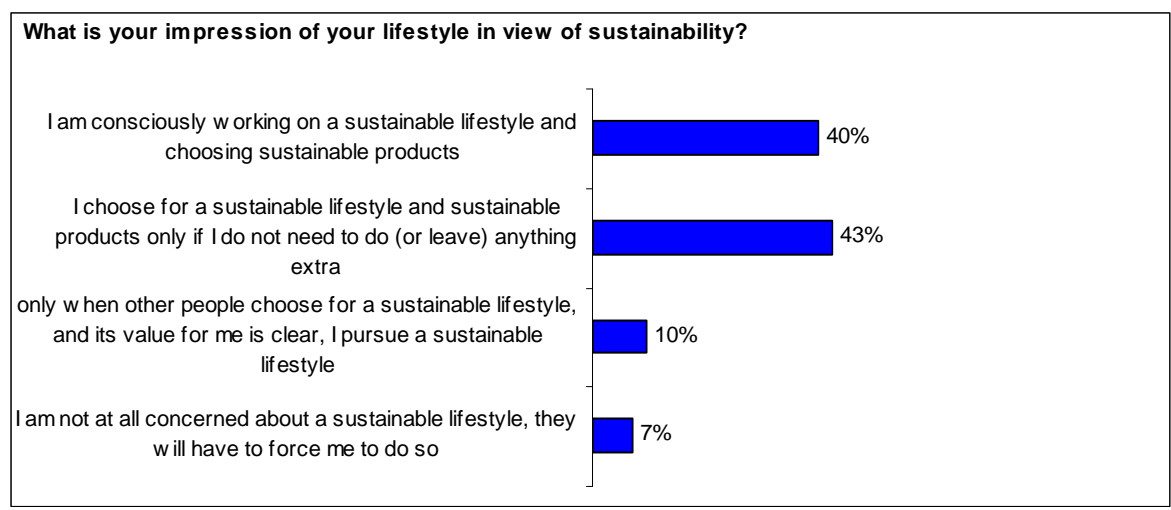

Figure 4.3: A sustainable lifestyle

These results show that there is a vast majority who are pursuing a sustainable lifestyle (83\%). However, one can wonder if they truly pursue a sustainable lifestyle and also if a sustainable lifestyle can seriously be pursued without investing extra time or money. Then there is a group (10\%) that is conservative (they are only sustainable if others are doing it already) and that needs convincing (if the value for me is clear). Also there is a group (7\%) that needs forcing and is not living sustainable at the moment. Answers are dependent of gender (women more often say than men that they are consciously choosing a sustainable lifestyle), age (those respondents over 25 years also choose more consciously for sustainability than the respondents younger than 25), prior knowledge of sustainable development (those familiar with sustainable development more often say that they consciously choose a sustainable lifestyle and products. Those who are not familiar with sustainable development more often choose the options that they pursue a sustainable lifestyle only if its usefulness has been demonstrated and others do it, or if they are forced.) and education (those with a lower education more often choose the options that they pursue a sustainable lifestyle only if its value is clear and others do it too. More people with a lower education say they are not concerned about a sustainable lifestyle.).

We then asked people if they wanted to become more sustainable in the future (see Fig. 4.4). The majority of respondents say they do want to live more sustain- 
able if there is a clear effect or if there is clear information on sustainable development (36\%). Within this group, significantly more people older than 60 say this than the group of 25-60 years. Higher educated people say this more often than medium educated people. Those who are familiar with sustainable development more often say it.

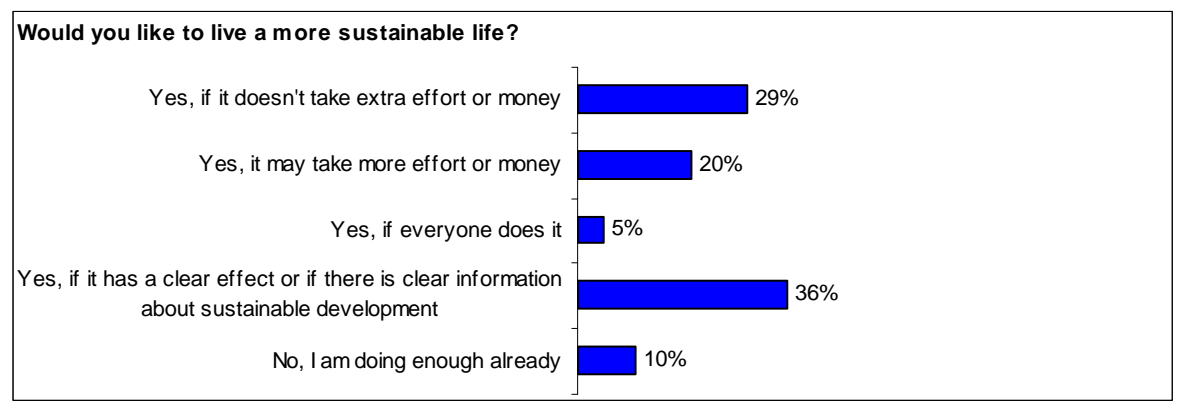

Figure 4.4: Becoming more sustainable

This is followed by a group of people who say that they would like to live more sustainable provided it doesn't take more money or efforts (29\%). Within this group those older than 60 more often say it than younger respondents. Lower and medium educated people more often say it than higher educated people. Those who are not familiar with sustainable development more often say it.

Next is the group who says that they wish to live more sustainable and it may cost more or take more efforts (20\%). Higher educated people say more often than lower educated people that they it may cost more or take more efforts. Those who are familiar with sustainable development more often say it too.

$10 \%$ say they already do enough. In this group we find mostly people who are already having a more sustainable lifestyle. Those older than 25 more often say that they already take enough action. Lower educated people say it more often than higher educated people. Those who are not familiar with sustainable development more often say that they already do enough.

$5 \%$ is willing to become more sustainable if everyone does it, in other words, if sustainable development is mainstream.

These results show us several insights:

- Information on clear effects of sustainable development measures or, in general, understandable information on sustainable development is needed for the $>60$ years, the higher educated people and the people familiar with sustainable development.

- Information is needed on sustainable alternatives that cost not more money or effort for the $>60$ years, the lower and medium educated people and those who are not familiar with sustainable development 
- Information on sustainable development in general is needed because once people are familiar with the concept they are more accepting of higher costs in time and money.

We have also asked people about the current efforts of the place where they work (see Fig. 4.5). 48\% of the respondents say that their work consciously chooses for a sustainable way of working and sustainable products.

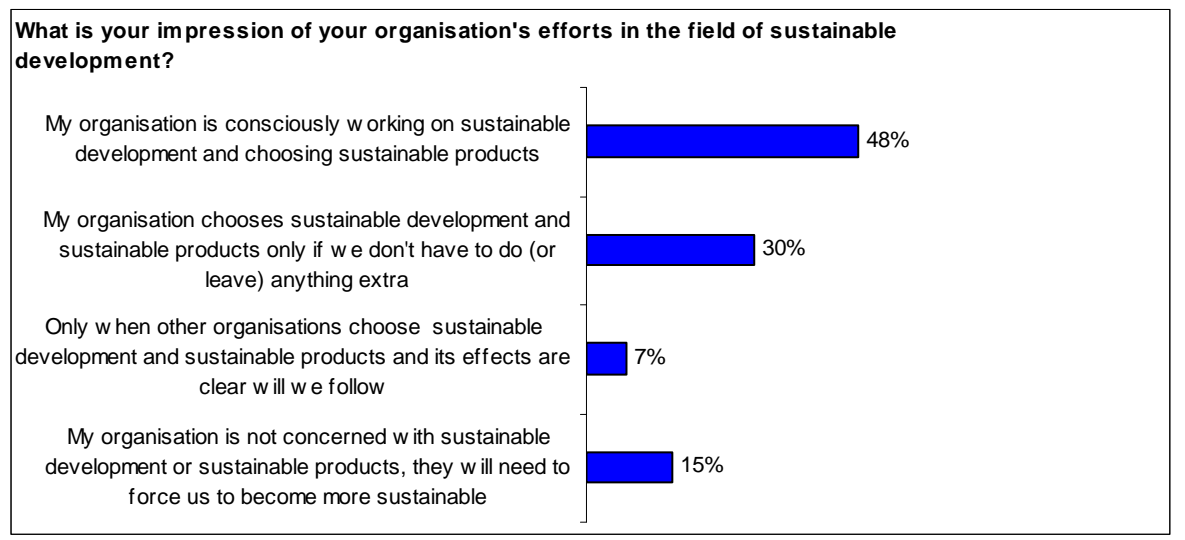

Figure 4.5: Sustainability of organisations

$30 \%$ say their work only chooses for sustainability if it doesn't cost more or takes more effort. Women choose this option more often than men. Higher educated people choose this option more often than lower educated people.

$7 \%$ say that their work will only choose for a sustainable way of working if others have done it previously and its usefulness has been demonstrated.

$15 \%$ say that their work is not at all concerned about sustainability and will need to be forced to adopt it. Those who are not familiar with sustainable development choose this option more often.

\subsubsection{Implications}

This section looked at how sustainable people say they are. $83 \%$ of the people say they include sustainable development in their lives, either when it costs more time or money, or when it is not more expensive and or more time consuming than traditional options. $90 \%$ of the people want to become more sustainable in future. This seems a great result, but there are some reservations. The first one is that a lot of people say it should not cost more time or money. People are willing to change if it is easy. Unfortunately easy change is not often possible, but it is an indication that we should look for easy options if we want people to become more sustainable. Secondly, people want to know the benefits for them. Apparently it is not clear how sustainable development will provide individual benefits. This might be 
related to the long time frame of sustainable development and its inherent focus on the "greater good". Related to this is a third point, that people want to be more sustainable if it has a clear effect, which seems a more general issue including both themselves and society. We should make clear what the effects are of sustainable development, which is were monitoring becomes important. However, the long time frame for sustainable development and its associated low visibility might again be a problem. Participatory monitoring, that gives citizens a role in monitoring might be a solution. The fourth point is that there is a group of people that will follow the mainstream. However, we saw in section 4.2 that sustainable development is not mainstream. Efforts should focus on improving that. And lastly there is the issue of people who need to be forced. Here one could think of regulation, financial incentives and banning unsustainable products and services.

Comparing sustainable behaviour of people to the perceived sustainability of organisations we see that people perceive themselves as being more sustainable than the organisation where they work. We might conclude that some regulation might be needed to get organisations to become more sustainable. However, also they will need information on actions that can be taken at various levels of input. And more research is needed on the exact situation, as we asked people about their work and did not ask companies and institutions. The perception of people about their work might be different from the facts (Table 4.3).

Table 4.3: Comparing private and company sustainable behaviour

\begin{tabular}{lll}
\hline & Work & Lifestyle \\
\hline Consciously sustainable & $48 \%$ & $40 \%$ \\
\hline Sustainable without extra cost or effort & $30 \%$ & $43 \%$ \\
\hline Sustainable when others do it and its value is proven & $7 \%$ & $10 \%$ \\
\hline Not sustainable, need to be forced & $15 \%$ & $7 \%$ \\
\hline
\end{tabular}

\subsection{How sustainable do people act?}

While the previous section looked at how people see themselves and their work in terms of sustainability, now we will investigate actual behaviour of the Limburg population. We asked people about their behaviour regarding mobility (4.4.1) and regarding their consideration for the procurement of goods and services (4.4.2).

\subsubsection{Mobility at home, work and school}

This section is devoted to mobility because mobility is an important aspect of sustainable development. On the one hand people's perception of quality of life depends on their freedom of travel, on the other hand, car use and air travel put a large burden on the environment. Also, mobility is something that concerns everybody on a daily basis. We asked people about their home situation regarding mobil- 
ity and how they went to work and/or school in order to find out how sustainable they act.

\section{Home situation}

$11 \%$ of the households in Limburg has no car, $58 \%$ has one car and $31 \%$ has two or more cars. The majority of households drives between 10.000 and $50.000 \mathrm{~km}$ annually (46\%). The amount of kilometres driven depends on gender (Men report this higher amount more often than women) and age (the $>60$ group drive more often lower numbers of $\mathrm{km} /$ year than the younger age groups). Education also plays a role but we suspect this is related to the type of work. Those with a lower or medium education drive less than those with a higher education and it is supposed the latter group chooses jobs or a place to live that is further away. Those who are not familiar with sustainable development more often drive distances less than $\mathbf{5 0 0 0}$ $\mathrm{km} / \mathrm{yr}$ than those who are familiar with sustainable development probably because those who are most familiar are those with a higher education and they drive longer distances.

The largest amount of kilometres is driven for shopping, personal care and appointments nearby home (59\%), visiting family, friends or a day out (55\%), commuting (53\%), holiday (34\%), social gatherings or sports and leisure nearby $(17 \%)$, and business (13\%) (Fig. 4.6).

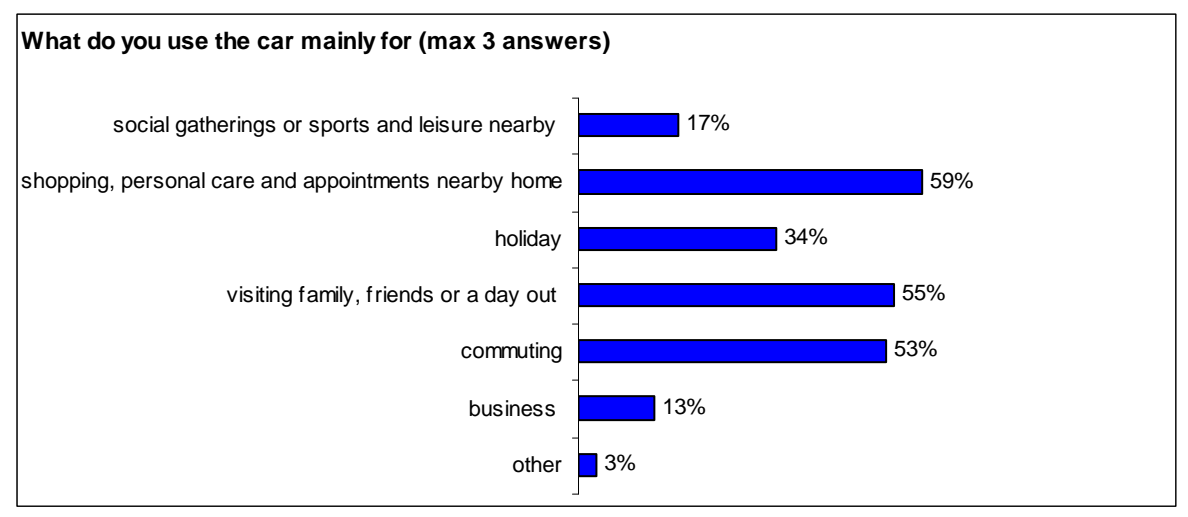

Figure 4.6: Car use

Women report more often than men that they use the car for commuting. Those younger than 25 report more often that they use the car for social gatherings or sports and leisure nearby. Those older than 60 drive less kilometres, but use them for other purposes: they use it more often for shopping, personal care and appointments nearby home, visiting family, friends or a day out and holiday.

Those with a lower education use the car more often for shopping, personal care and appointments nearby home than the medium and higher educated respon- 
dents. The higher educated respondents used the car more often for business appointments than the lower and medium educated people.

\section{Work}

After the general picture we get from our questions on car use, we wanted to know how people go to work and why they choose a certain type of transport. $70 \%$ of the respondents use private motor traffic (car, motor, moped, scooter) to travel to work. $44 \%$ use their own strength (walking, cycling) and $11 \%$ use public transport to get to work. The age group 25-60 uses public transport significantly less than the younger and older population. Those who work for a big organisation more often use private motor traffic to get to work than those working for a micro-size company (Fig. 4.7).

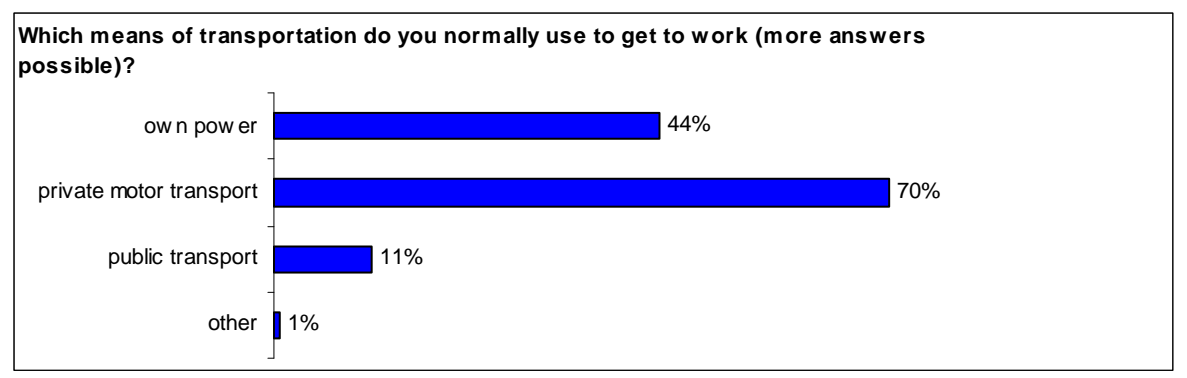

Figure 4.7: Means of transportation for commuting to work

The top-3 of reasons for choosing a particular way of travelling to work is: fast $(47 \%)$, easy (45\%), necessary because of the location (31\%). Health and costs are considerations on place 4 and 5 respectively, whereas care for the environment comes only on the $8^{\text {th }}$ place with $9 \%$ (Fig. 4.8). 


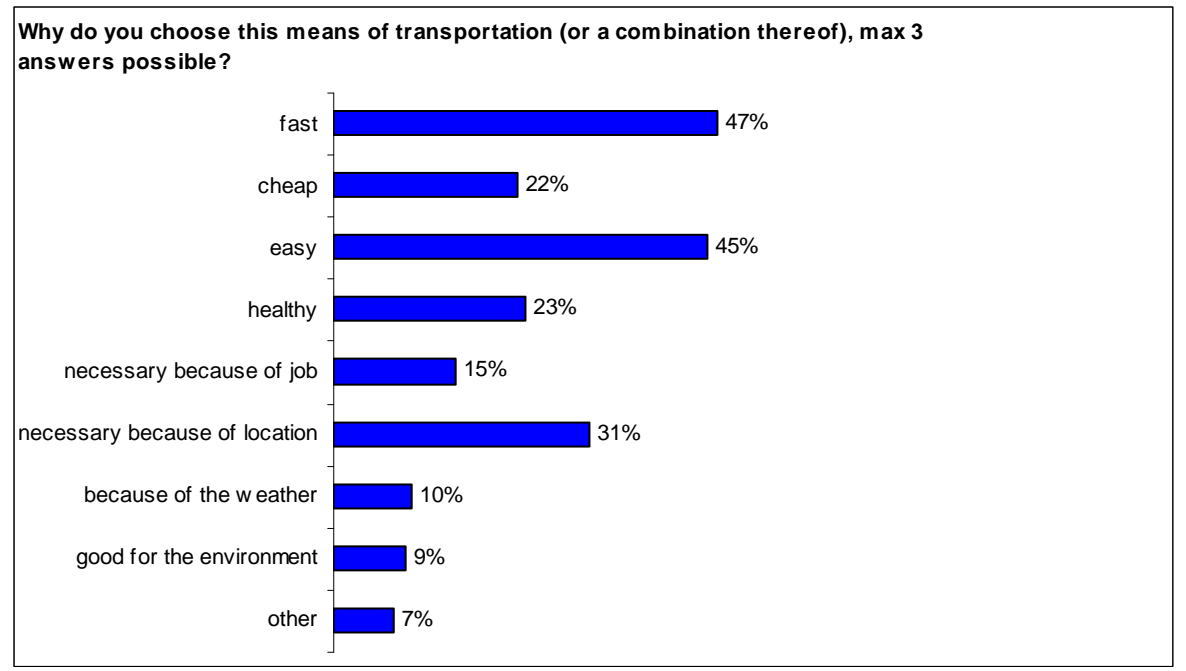

Figure 4.8: Reasons for choosing specific transport (work)

We see that private motor traffic is the most important means of transport for the majority (62\%), followed by $31 \%$ for walking or cycling, and $7 \%$ for public transport (Fig. 4.9).

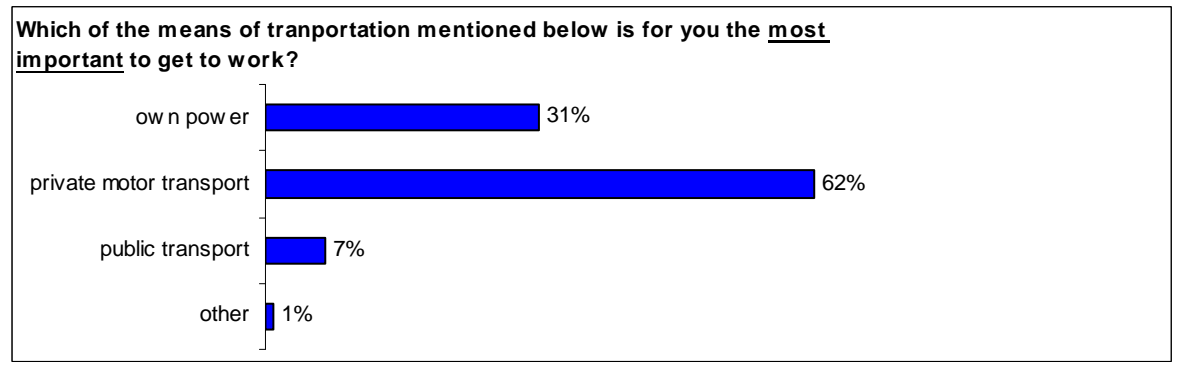

Figure 4.9: The most important means of transportation to work

Important to know is the amount of time people travel to their work. This gives an indication of what they think is acceptable. We could then think of alternative ways of transport that remain within that acceptable time frame. $71 \%$ of the respondents are travelling less than half an hour to their work, $21 \%$ half an hour to an hour, and $7 \%$ an hour or more. Medium and higher educated people travel more often longer times than lower educated people.

Also important is the distance they cover. If for instance they cover large distances, it is logical they choose motorised transport. Most people travel more than $10 \mathrm{~km}$ to their work (49\%), 27\% travel less than $5 \mathrm{~km}$, and $25 \%$ between 5 and $10 \mathrm{~km}$. 
Private motor traffic becomes important for distances above $5 \mathrm{~km}$ (24\% for $5-10$ $\mathrm{km}, 64 \%$ for $>10 \mathrm{~km}$ ), cycling and walking is most important for distance less than 5 $\mathrm{km}(62 \%)$ and becomes less important for distances $>10 \mathrm{~km}$ (table 4.4). Public transport is relevant for distances above $10 \mathrm{~km}(85 \%)$.

Table 4.4: Distance travelled correlated with type of transport (work)

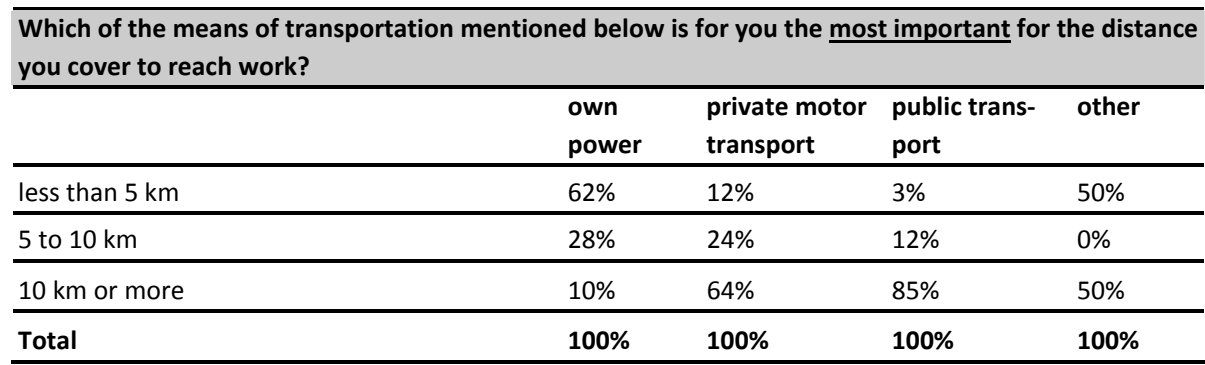

We also asked people about the incentives to use environmentally friendly transport. Only $34 \%$ of the respondents report that their organisation stimulates environmentally friendly means of transport. $43 \%$ say there is no stimulation and $23 \%$ do not know. Public organisations seem to have more stimulation of environmentally friendly means of transportation than others. Large organisations have more stimulation of environmentally friendly means of transportation than small and medium size enterprises (SMEs).

\section{School}

The group of respondents going to school (students only) is different from the working group. This is demonstrated in their mobility behaviour. Contrary to the results for mobility to work, the majority of respondents use their own power to get to school (67\%). $36 \%$ uses public transport and on the third place we find private motor transport with $27 \%$ (Fig. 4.10).

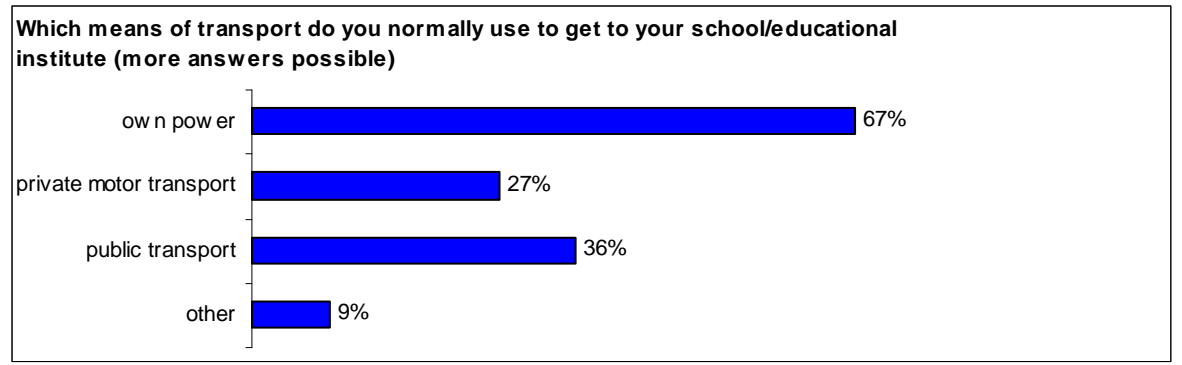

Figure 4.10: Means of transportation for commuting to school

The top-3 reasons for choosing a particular way of travelling to school is: fast (46)\%, easy (43\%), cheap (38\%) (Fig. 4.11). 


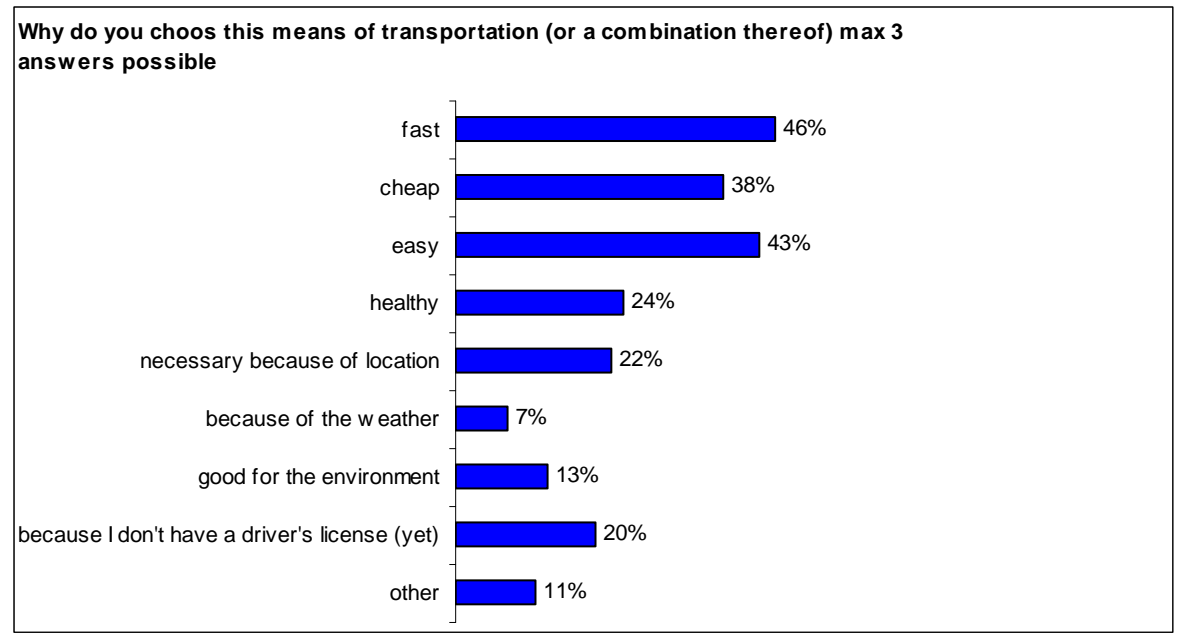

Figure 4.11: Reasons for choosing specific transport (school)

Respondents say that walking or cycling is the most important means of transport with $47 \%$, followed by $25 \%$ for public transport and $21 \%$ for private motor transport (Fig. 4.12).

$61 \%$ of the respondents are travelling less than half an hour to their school, $23 \%$ half an hour to an hour and $16 \%$ an hour or more.

Most people travel more than $10 \mathrm{~km}$ to their school (41\%), closely followed by less than $5 \mathrm{~km}(39 \%)$ and $21 \%$ between 5 and $10 \mathrm{~km}$.

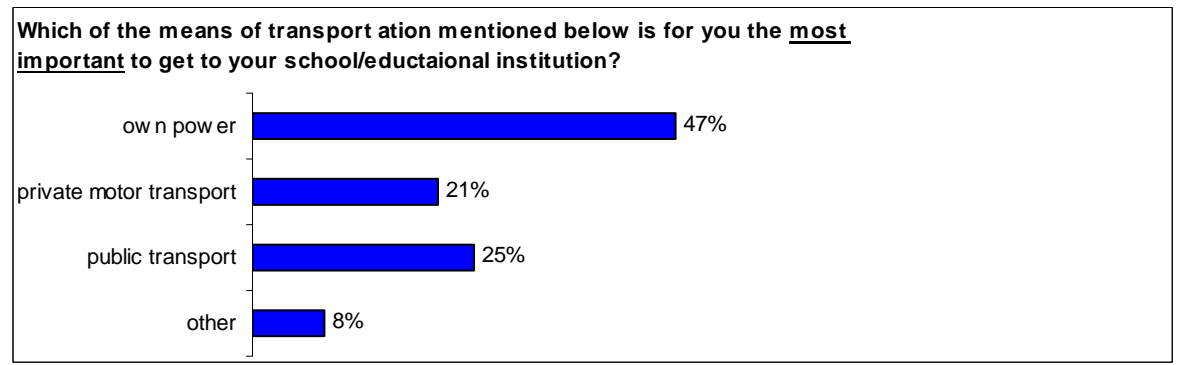

Figure 4.12: The most important means of transportation to school

Private motor traffic becomes important for distances above $10 \mathrm{~km} \mathrm{(67 \%} \mathrm{for}$ $>10 \mathrm{~km})$, cycling and walking is most important for distance less than $5 \mathrm{~km}$ (59\%) and becomes less important for distances $>10 \mathrm{~km}$. Public transport is relevant for distances above $10 \mathrm{~km}$ (91\%) (Table 4.5). 
Table 4.5: Distance travelled correlated with type of transport (school)

Which of the means of transportation mentioned below is for you the most important for the distance
\begin{tabular}{lllll} 
you cover to reach your school/educational institution? & $\begin{array}{l}\text { own } \\
\text { power }\end{array}$ & $\begin{array}{l}\text { private motor } \\
\text { transport }\end{array}$ & $\begin{array}{l}\text { public trans- } \\
\text { port }\end{array}$ & other \\
\hline less than $5 \mathrm{~km}$ & $59 \%$ & $14 \%$ & $2 \%$ & $100 \%$ \\
\hline 5 to $10 \mathrm{~km}$ & $32 \%$ & $19 \%$ & $7 \%$ & $0 \%$ \\
\hline $10 \mathrm{~km}$ or more & $10 \%$ & $67 \%$ & $91 \%$ & $0 \%$ \\
\hline Total & $\mathbf{1 0 0 \%}$ & $\mathbf{1 0 0 \%}$ & $\mathbf{1 0 0 \%}$ & $\mathbf{1 0 0 \%}$ \\
\hline
\end{tabular}

Striking is that a large proportion of respondents does not know if environmentally friendly transport is encouraged (41\%). Another $41 \%$ says that it is not encouraged and only $18 \%$ say it is encouraged.

\section{Implications-mobility}

The aim of this section was to see what people actually do regarding sustainable development in the field of mobility. Sustainable development for mobility has been mainly expressed as environmental care in the survey. An important conclusion is that care for the environment is not an important consideration for the means of mobility that is chosen. Stimulation of environmentally friendly transport is done by public organisations and large organisations, but much less by others.

This study offers several entry points for increasing sustainable mobility. First, we saw that people use the car a lot for short distances around their homes, visiting family and friends, which makes clear that attention will be needed there. Secondly, people use the car a lot for commuting. Some interesting results become clear when we compare the results from work with school. We see that travelling to school involves more own muscle power and public transport than private motor transport. Private transport is the most important means for going to work. Apparently, once people start working they partly stop using the bicycle or public transport and use their private transport (Table 4.6). However, $20 \%$ of the students (who are mainly in the age-group below 25 years) mention that their reason for choosing a certain type of transport is because they do not have a driver's licence (yet). This is a group that might change to private transport as soon as they have a license.

Table 4.6: Most important means of transport for work and school

\begin{tabular}{lll}
\hline & Work & School $^{\mathbf{1 3}}$ \\
\hline Own muscle power & $31 \%$ & $47 \%$ \\
Private motor transport & $62 \%$ & $21 \%$ \\
Public transport & $7 \%$ & $25 \%$ \\
\hline
\end{tabular}

\footnotetext{
${ }^{13}$ The unaccounted for $8 \%$ that makes the list amount to $100 \%$ is the category "other", which represents mainly those students who study from home and do not need transport.
} 
The reasons for choosing a certain type of transportation is mainly because it is fast and easy. Not surprisingly, an important reason for students is the cost ( $3^{\text {rd }}$ place). However, for those who work, the costs come at a $5^{\text {th }}$ place and the location of their work is a more important factor for choosing their means of transport. There possibly is a link between costs and choosing bicycle/walking and public transport (Table 4.7).

Table 4.7: Top-3 reasons for choosing certain transport

\begin{tabular}{lll}
\hline & Work & School \\
\hline Fast & $1(47 \%)$ & $1(46 \%)$ \\
Easy & $2(45 \%)$ & $2(43 \%)$ \\
Cheap & $5^{\text {th }}$ place $(22 \%)$ & $3(38 \%)$ \\
Necessary because of location & $3(31 \%)$ & $5^{\text {th }}$ place $(22 \%)$ \\
\hline
\end{tabular}

Also the distance plays a role in the type of transportation chosen. We have seen earlier that the longer the distance travelled, the more there is a shift from muscle to motor power. Also, half an hour commuting seems to be the average. However, at $5-10 \mathrm{~km}$ there seems to be a gap: people rely less on muscle power, and do not take the bus or train, but rather private motor transport, although cycling could still be an option.

\subsubsection{Sustainability considerations at home and at work}

This section aims at finding out which choices people make in their daily lives (at home and at work) in order to see how sustainable they are. Activities that were targeted for the domestic situation are issues such as shopping for food, buying a car, choosing a holiday destination. The questions asked on this topic in the questionnaire have been designed with the social practices model by Spaargaren in mind (Spaargaren, 2003). The results were grouped according to this model into activities in the field of Leisure, Consumption, Mobility and Dwelling. Mobility has been extensively covered in the previous section and does not feature here. Possible considerations were derived from corporate social responsibility criteria (MVO Platform, 2007), in addition to the considerations for cost and quality, and grouped into the categories social considerations (working circumstances and trade relations at producer's), economical considerations (costs), environmental considerations (environmental pressure), quality consideration, or any other consideration.

Regarding work, answers have been grouped by social practice relevant to the topic of work, comparable to those for the household: production process and consumption (compares to consumption), mobility (compares to mobility), using the office building (compares to dwelling in). For obvious reasons, leisure was not part of the work related questions. These questions were not asked of students, because it was assumed that they would not have extensive knowledge about school man- 
agement. The meagre response for the work situation where people are probably more involved than students at school, shows our assumption to be viable.

\section{Home}

The activities that were done most often in the households of the respondents in the past 6 months before the survey, were shopping for food, buying clothes, separating waste, doing repairs or renovation, buying electrical appliances (Fig. 4.13). These are part of the categories Consumption and Dwelling.

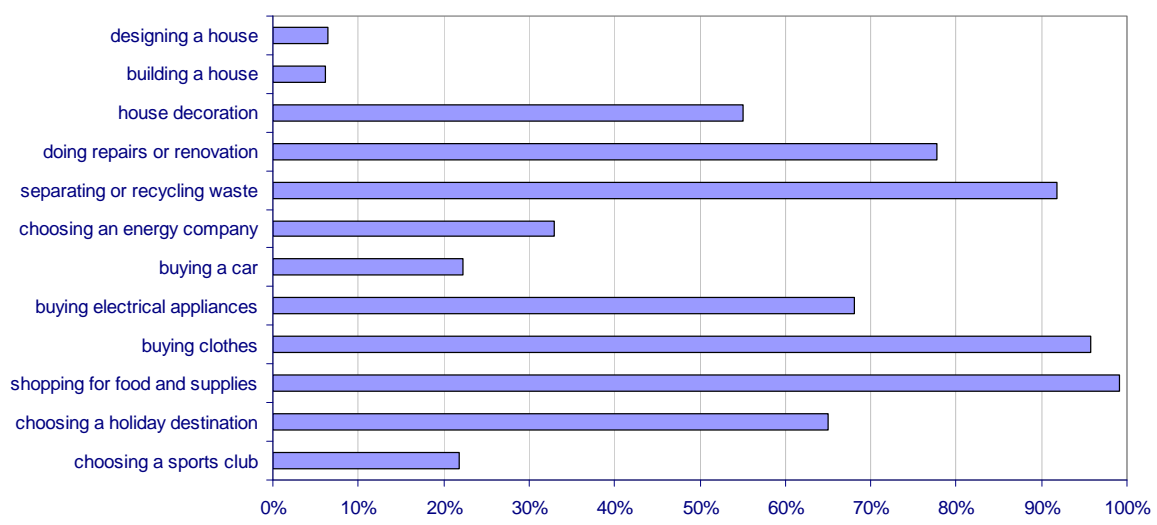

Figure 4.13: Activities in households in the 6 months before survey

Regarding shopping for food and buying clothes, these appear to be female dominated activities $(66 \%$ and $76 \%$ respectively). Younger people $(<25)$ go shopping for food less often in person than the over-25s, but they do buy most often their own clothes (77\%).

Of the respondents who indicated that they were responsible for separating waste, the majority were women ( $52 \%$ women, 39\% men). Repairs and renovation are done more often by men then by women, and more often by the cohort older than 60 years. Of the respondents who indicated that they bought electrical appliances the majority was male. This distinction is important because we see that different groups conduct different activities.

Economical and quality considerations are always among the two most important considerations mentioned, with two exceptions: for choosing an energy company environmental considerations take the second place after economical considerations, and in separating waste environmental considerations are many leagues in front of the number two: economic considerations. Social and environmental considerations, two important pillars of sustainable development, are slightly important only in buying a car (environmental considerations), and in designing and building a house (social considerations). Other, non-listed considerations are im- 
portant only in the two leisure topics: choosing a holiday and choosing a sports club. Below, the results are described in more detail per social practice.

\section{Leisure}

In the Leisure category we find choosing a sports club and choosing a holiday destination. For choosing a sports club there were many other considerations mentioned than the pre-defined answers, such as the distance from home, its location, accessibility, the sports supply, and friends. For choosing a holiday the other considerations were the weather, culture, suitability for children, distance, availability, etc. Of all possible considerations, the most important consideration was quality followed by economic considerations for choosing a sports club and economic considerations over quality for choosing a holiday destination. Social and environmental considerations were only mentioned in $2 \%$ of the cases as most important considerations (Fig. 4.14).

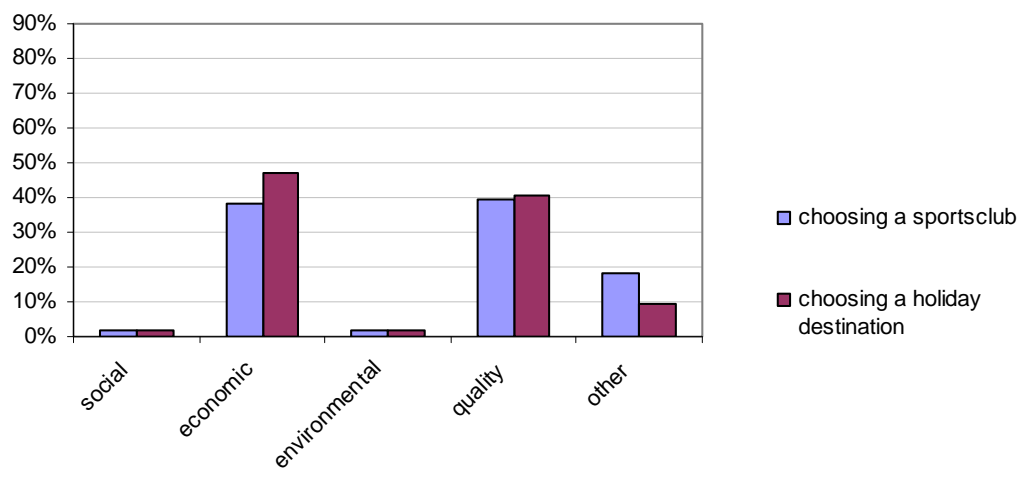

Figure 4.14: The most important considerations for Leisure

\section{Consumption}

In the consumption category we find shopping for food, buying clothes, buying electrical appliances, choosing an electricity company and buying a car. (Fig. 4.15) For the first three actions economic and quality considerations were mentioned most often. For choosing an energy company environmental considerations are important (2nd place with $19 \%$ after costs $64 \%$ ). For buying a car environmental issues are mentioned as the third most important factor (13\%).

Environmental and social considerations are slightly more important than in the Leisure category. For $30 \%$ of the people the environment is a consideration when buying electrical appliances, and for $19 \%$ of the people it is a consideration in buying food. For $13 \%$ of the respondents social issues are a consideration when buying clothes, and for $11 \%$ when buying food. However, it is not the most important consideration for many of them. 
When shopping for food, people older than 60 have more social and environmental considerations than the other age groups. Quality is most important for higher educated respondents, and those respondents who are familiar with the concept of sustainable development more often take into account social and quality considerations.

When buying clothes, economic considerations are more often made by men than by women. Quality is more important for the respondents younger than 25 . The respondents who are familiar with the concept of sustainable development more often take into account social and quality considerations.

Environmental considerations are more often important for the respondents older than 60 than those younger than 25 when buying electrical appliances. Especially environmental considerations, but also social considerations are more often mentioned by the respondents who are familiar with the concept of sustainable development.

For choosing an energy company the respondents older than 60 take more often environmental considerations into account than those younger than 25 . Those between 25-60 more often choose for economical considerations than the respondents younger than 25 .

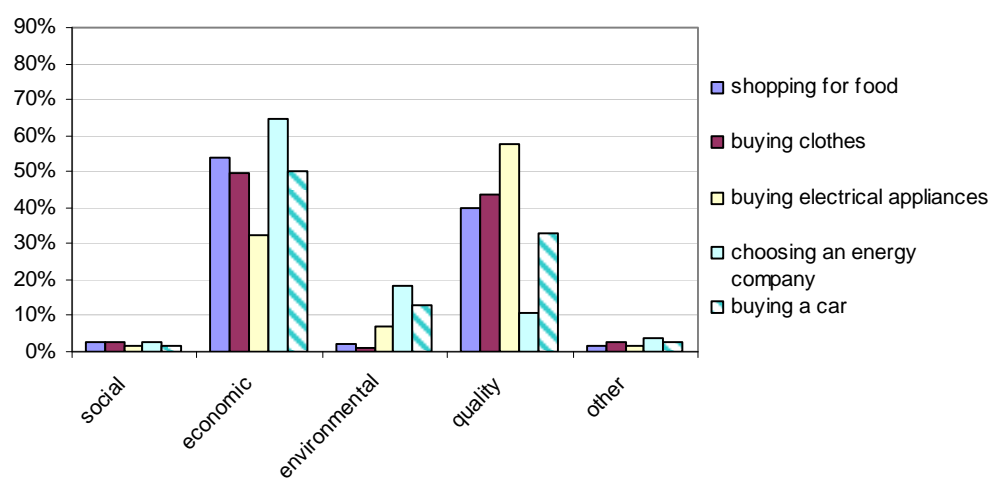

Figure 4.15: The most important considerations for Consumption

\section{Dwelling}

This category comprises choosing an energy company, separating waste, repairs and renovations, decorating a house, building a house and designing a house. Several things are different in this category. For separating waste environmental considerations are important. In the case of separating waste they were mentioned far more than economic considerations ( $84 \%$ vs. $17 \%$ ). The other actions in dwelling depend largely on quality and economical considerations. However, for building and designing a house social considerations are seen as third most important consideration (Fig. 4.16). 
When separating waste, higher and medium educated respondents give more importance to environmental considerations than lower educated respondents. Medium educated people give more often priority to economic considerations than higher educated ones. There is a significant difference between those who are familiar with sustainable development and those who are not, in taking into account environmental considerations when separating waste ( $86 \%$ vs. $77 \%$ ).

In doing repairs and renovations, men think quality of greater importance than women. Respondents older than 25 think more of environmental, economic and quality considerations and those who are familiar with sustainable development more often apply quality and environmental considerations for repairs and renovations than those who are not familiar with the concept.

Regarding decorating the house, more women than men have economic considerations. Economic and environmental considerations are more prevalent with the age group 25-60 than with those younger than 25 , while the over-60 group takes social issues into account more often than the 25-60 year age group. The higher educated respondents see quality as more important than the medium or lower educated respondents. Those who are familiar with sustainable development more often choose quality as a consideration for repairs and renovation than those who are not familiar with the concept.

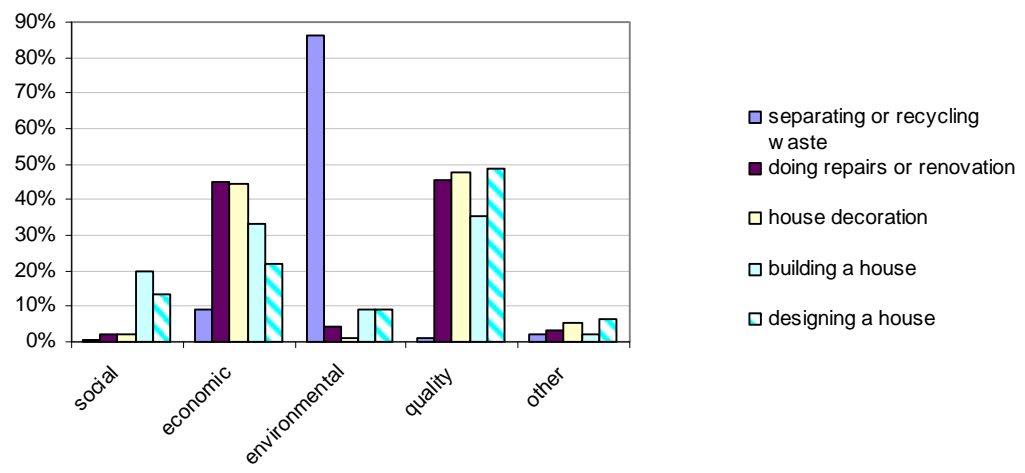

Figure 4.16: The most important considerations for Dwelling

In general, costs and quality determine the actions people take at home. Exceptions are for separating waste, buying a car and choosing an energy company for which environmental considerations play a role $(>10 \%)$. Social considerations play a role only in building and designing a house (>10\%). In the next section we will see the considerations at work. 


\section{Work}

Only small numbers of respondents indicated that they have been directly or indirectly involved in making decisions about the production process, mobility or issues related to their office building, and even smaller number have directly been involved. This is surprising in some issues, as probably many people working in offices have at least seen someone cleaning their office or have thrown away waste and been confronted by separate paper baskets or glass containers, etc. We thought that this might be because only management makes certain decisions, and the amount of managers/supervisors is rather limited in this survey $(21 \%)$, but this was only a significant difference in the procurement of services. The question remains: why are people not involved and who makes the decisions? Are we behaving at work in a sphere of ignorance? Nevertheless, waste management and cleaning are the activities that most people have been involved in (directly or indirectly), followed by procurement of non-electrical products, repairs and travel. In the considerations we see the same criteria as for the household with an addition called "rules". This is because many organisations have their corporate rules about how certain things are done.

\section{Production process and consumption}

This includes procurement of services, raw materials, non-electrical products, electrical appliances, energy, catering and procurement of company vehicles.

For all activities in this category economy and quality are the most important considerations. Only for energy procurement we see that environmental, social and quality considerations are on the second place (ex-aequo 10\%), but economic considerations are far more important (65\%). Economic considerations are much more important in the procurement of non-electrical products (economic 63\%, quality $28 \%$ ). Regarding catering, also rules set by the company are important (third place $11 \%)$. When buying a company vehicle, the environment becomes a matter for consideration (10\%). For people working at an SME economical considerations in the procurement of non-electrical products are more important than for those working at a large organisation (Fig. 4.17). 


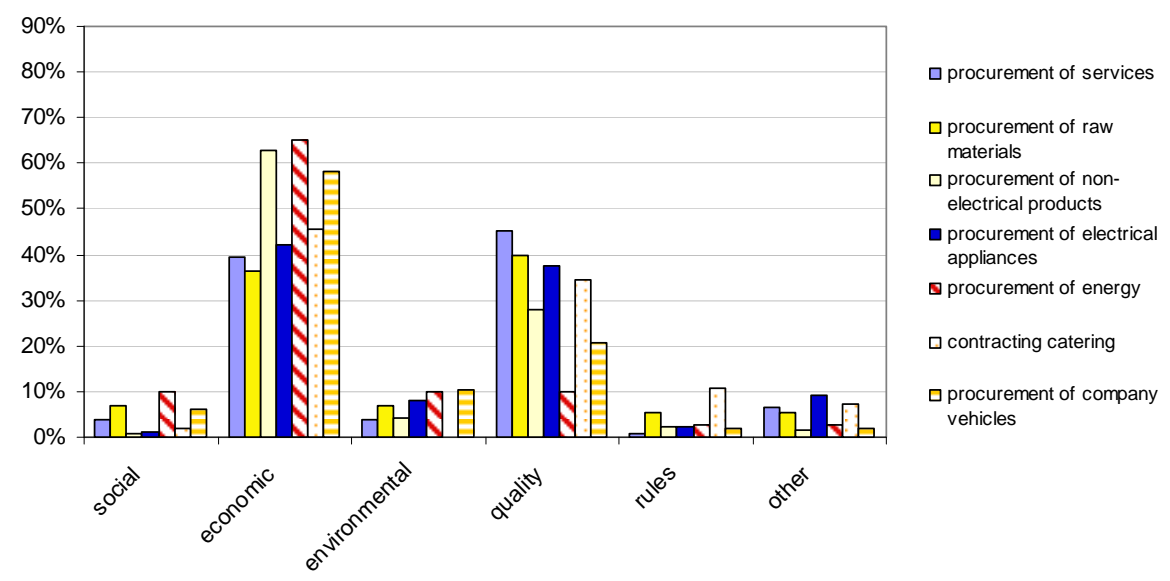

Figure 4.17: The most important considerations for the production process and consumption

\section{Using the office building}

This includes designing, building, renovating and decorating an office building, cleaning, waste management and repairs. We see that people working at an SMEs and lower educated people have been more directly involved in cleaning. Economic considerations prevail over quality considerations with one exception: in waste management where environmental considerations are most important with $57 \%$ followed by economy with $24 \%$. Quality considerations have played a larger role for men than for women in office decoration. Quality of repairs is more important for those familiar with sustainable development than for those who are not. Costs are a more important consideration in repairs with SMEs than with people working in a large organisation (Fig. 4.18).

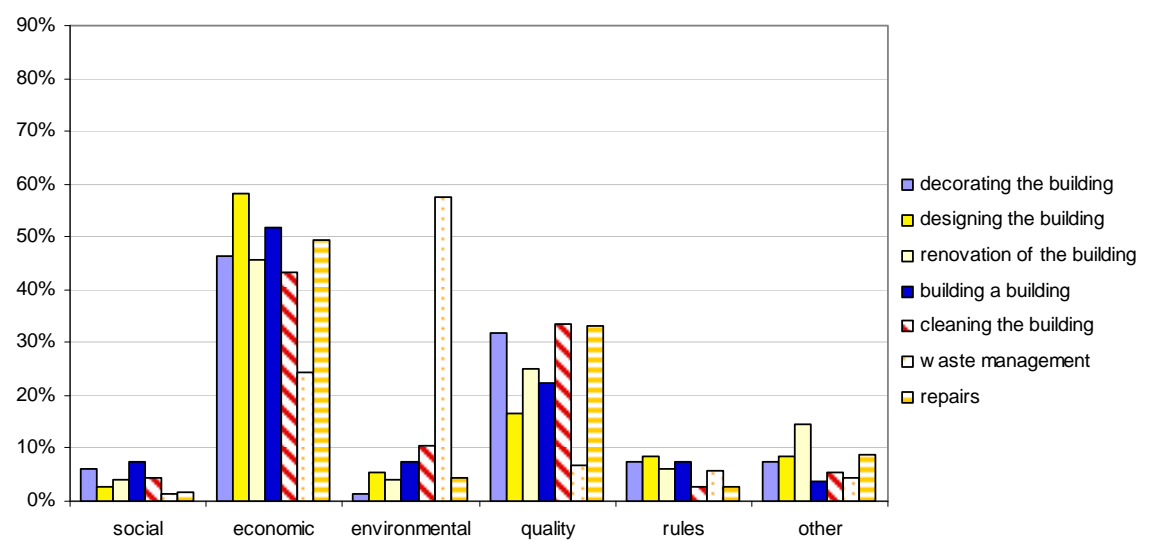

Figure 4.18: The most important considerations for using the office building 
For the work situation in general we see similar trends as for the home situation. Cost and quality are the most important considerations. Environment plays a role $(>10 \%)$ in waste management, procurement of company vehicles and procurement of energy. Social considerations play a role $(>10 \%)$ in procurement of energy only. Company rules determine behaviour for at least $10 \%$ only regarding catering contracts.

\section{What product information do people want?}

One could think that the reason for people focusing mainly on the cost and quality aspects is that not a lot of product information exists on social and environmental matters. Therefore, we asked people what kind of product information they would like to get. We aimed at finding out if people are interested in sustainability information even though it may not yet exist. It turned out that the information that people thought was most important for deciding to procure a specific product or service was the shelf life (81\%), ingredients (66\%), and environmental information, such as energy needed for production or energy consumption during use, way of production, product miles, eko/FSC/MSC labels (57\%). We see that the well-known types of information score high (shelf life (1), ingredients(2) and calories(4)) (Fig. 4.19). And again we see a preference for environmental information more than for social information.

Women see information on ingredients, shelf life, calories and social as more important than men. People older than 60 say that information on calories and environment is more important than younger people. Higher educated people think ingredients of greater importance than lower educated people. People familiar with sustainable development think ingredients, environment and spatial information more important than people who are not familiar

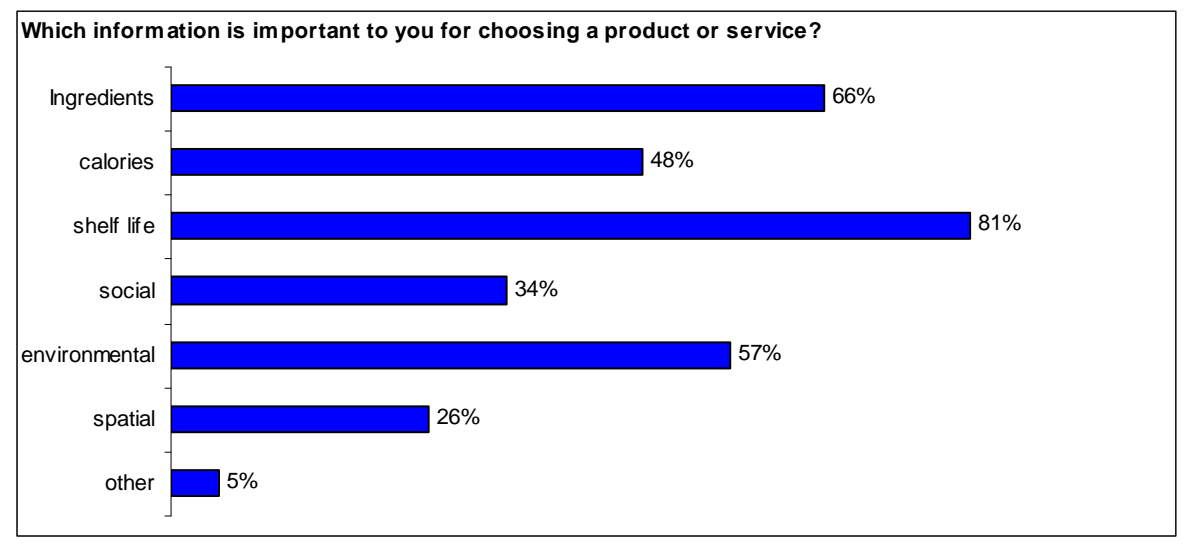

Figure 4.19: Important product information 


\section{Sustainability considerations at home and at work - implications}

The aim of section 4.4.2 was to investigate which choices people make in their daily lives (at home and at work) in order to see how sustainable they are. An important conclusion is that economic and quality considerations are by far the most important considerations. In a few cases, such as separating waste, procuring energy and buying a car, environmental considerations are of some importance. Social considerations are hardly of any importance. However, it should be mentioned that social information is hardly present for the goods and services mentioned here, meaning that it is very hard to consider social aspects when they are not documented. Therefore, people were asked about their information needs. We can see that the well-known types of information score high and that there is a preference for environmental information more than for social information. So, people probably need to be made aware of the importance of the social dimension in sustainable development.

\subsubsection{Implications}

Section 4.4 aimed at testing the hypothesis that people show sustainable behaviour but don't always call it that. The idea behind this hypothesis was that if people don't know about sustainable development, they will not call their behaviour sustainable while they are doing sustainable things. But if there is sustainable development already present, governance could concentrate on making people aware of the good things they already do, instead of having to change a mindset, which is far more difficult. We investigated mobility and procurement of goods and services.

Regarding what people do, we could not observe sustainable behaviour in the topics that were analysed. An important conclusion regarding mobility is that care for the environment is not an important consideration for the means of mobility that is chosen. Stimulation of environmentally friendly transport is done by public organisations and large organisations, but much less by others.

An important conclusion regarding the choices people make in their daily lives (at home and at work, not mobility) is that economic and quality considerations are by far the most important considerations. In a few cases, such as separating waste, procuring energy and buying a car, environmental considerations are of some importance. Social considerations are hardly of any importance. All in all, this shows a very unbalanced picture of behaviour from a sustainable development perspective. (Fig. 4.20) 


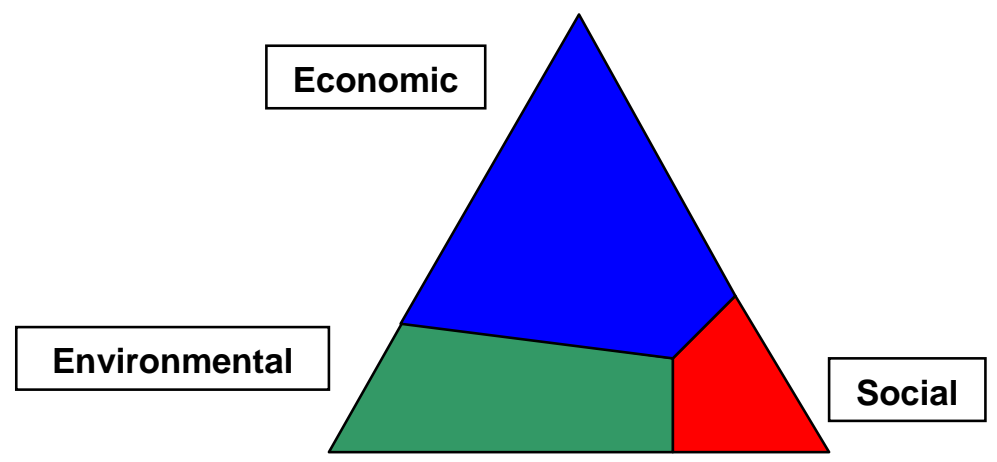

Figure 4.20: An unbalanced picture of sustainability

This means that our hypothesis could not be confirmed for the topics researched. People do not show sustainable behaviour. Given the fact that environmental considerations play such a small role, we could even conclude that environment is not mainstream, which is divergent from the conclusion of section 4.2. It should be noted that for the actions mentioned in section 4.2, cost and quality are less present than in the actions investigated here, and the type of questions was different. Maybe our conclusion should be that environment is mainstream when cost of environmentally friendly solutions are not higher and quality is not less than for traditional solutions. This is congruent with the conclusion of section 4.3 which says that people are willing to change if it is easy and if it does not cost more time or money. Furthermore, we saw in section 4.2 that people have not received a lot of information on sustainable development, and thus we could argue that ignorance is a possible reason too for unsustainable behaviour.

However, the study of people's behaviour gives us some indications of the barriers that need to be bridged for people to become more sustainable. After all, people indicated that they are willing to become more sustainable.

First of all, different groups need different approaches. We should be aware that there are differences in activities and in considerations with respect to age, gender, education and awareness, and company size. Those who know more about sustainable development more often indicate social and environmental considerations. However, it has become clear that people have received very little information on sustainable development. A result that has popped up repeatedly is that respondents younger than 25 show less sustainable behaviour and less sustainability considerations than older people. Therefore, this group needs special attention. The $<25$ 's most likely have fewer possibilities for behaving in a sustainable way because they are dependent of their parents. However, they are the working class of tomorrow and need to be aware of what they can do. Next, small organisations 
do less about sustainable development than big ones, and also need special attention.

In any case, individuals and organisations need to be provided with information on sustainable development. In this section it has become clearer what kind of information is needed: it should be explained that economy, environment and society are all part of the picture, why sustainable development is important and what individual benefits a sustainable lifestyle can have. People also indicated they want to know what the effects are of sustainable behaviour.

Another angle is by providing people with product information on sustainable development. They indicated no great preference for sustainable development product information, but that could be due to ignorance. Once they know more, they will have more need for sustainable development information. Regulation will be needed to get sustainability information for products and services. Furthermore, one could give people a checklist with questions to ask to determine for themselves the sustainability of their actions (see chapter 3 ). A calculator that helps to make the impacts of their choices visible could also be helpful.

Furthermore, people indicated they want to change, but only without extra costs or efforts. That means that the sustainable option needs to become the easiest option with acceptable quality and cost. People should not be bothered too much with deciding what is sustainable and what not. Therefore, regulation and financial incentives seem to be the most appropriate.

Regarding mobility, we have learned about specific behaviour that could be made more sustainable. People use their car often for trips around the home and for day trips. One could think of stimulating alternatives for close-by-home car use by improving neighbourhood taxi services and delivery services. For day trips, accessibility of main railway and speed-bus connections could be improved to stimulate longer distance travel by public transport and improve car-pooling and car-sharing facilities.

Another issue that came up was the issue of costs related to commuting to work or school. If people work, costs are not the most important factor for choosing a preferred type of transport. However, when they still go to school, costs are important. Therefore, we think that if costs become more of an issue, people might prefer to choose public transport for the larger distances and muscle power for smaller distances. Of course, there are many other factors also related to the choice for a certain type of mobility. For instance, people indicated that speed and accessibility are important factors for choosing a transport type for commuting. Alternative mobility to private motor transport should offer this. Then, there was a gap of op- 
tions used at the distance of 5-10 km. Public transport is not used a lot for distance below $10 \mathrm{~km}$, nor is the bicycle. It could be stimulated that people take the bus more and, simultaneously, public transport services could be improved. Another option is stimulating bicycle use. Average bicycle speed is $20 \mathrm{~km}$ an hour. The average time for commuting is around $\mathbf{3 0}$ minutes, which means that distances up to 10 $\mathrm{km}$ could be travelled by bicycle. However, most organisations do not appreciate sweaty employees and facilities for changing and refreshing are often not adequate. Also, people prefer not to get wet, or cold, or tired. Finally, we saw that incentive schemes for environmentally friendly transport are not present everywhere. Therefore, employers and schools should be stimulated (especially small and medium size organisations) to set up incentive schemes and creative mobility solutions.

It is important to note that a comprehensive campaign is needed to help people to become more sustainable with clear benefits and concrete help. Many issues are interrelated and just taking one measure will not be very effective.

\subsection{Who should take the lead?}

Repeatedly in the outcomes of other questionnaires it has been indicated that government should take the lead in sustainable development (iNSnet, 2006; 2007; 2008). In general, citizens in Limburg trust municipalities and the provincial administration more than higher level government entities such as the national government and the EU (Province of Limburg, 2010a), but it was not known if this was true for sustainable development too, nor was it known how people expect government to take action. This was examined in this survey. It was also explored to what extent other players, such as market parties research and education and civil society groups, should play a role in the arena of sustainable development.

Not surprisingly, a large majority states that government should take the lead in sustainable development (94\%), followed at a large distance by the market $(40 \%)$, civil society (36\%), and research and education (22\%). (Fig. 4.21)

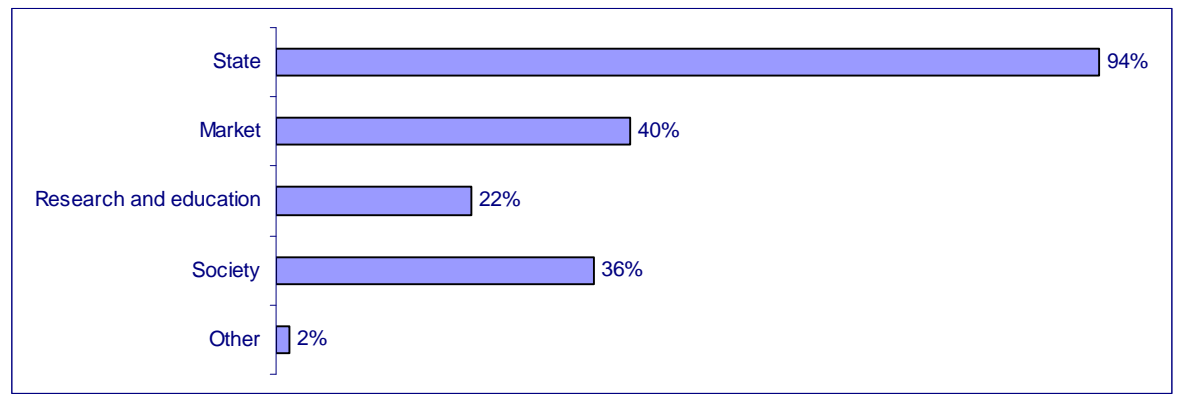

Figure 4.21: Who should take the lead? 
Another question that was asked is how each group should take the lead. In the tables below this is translated as "instruments". Interestingly, vision and goals were mentioned most often (30\%). This was followed by action (21\%) and by legislation and regulation (20\%). (Fig. 4.22) The results per "leader" are described below.

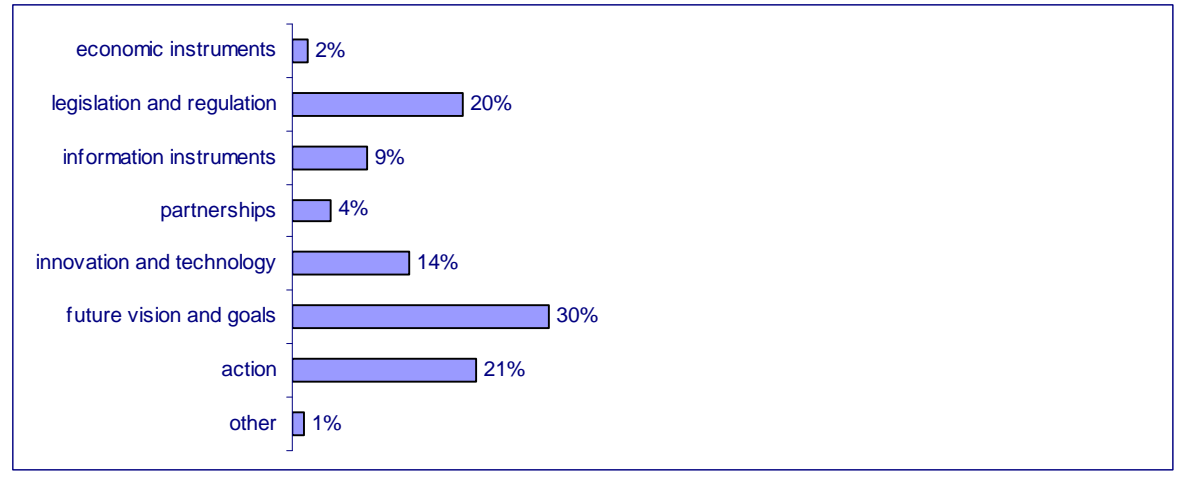

Figure 4.22: The most important instruments for sustainable development

\section{Government}

This category includes government and international/transnational organisations at various levels: municipality, province, national, EU and UN. What is interesting is that respondents not only say that government should ensure sustainable development via rules and regulation, but also by taking action. Of special interest is the fact that respondents say that at all levels a vision on the future is important and goals should be set. At the lowest scale level of municipalities, information is seen as an important way to take the lead. Action is seen as less important for the EU level. However, most respondents choose the higher levels of government (national government and EU) for taking the lead, which is contrary to the lower levels of trust in these levels. Another interesting fact is that economic instruments are seen as of so little importance(Table 4.8). 
Table 4.8: Government: importance and instruments

\begin{tabular}{|c|c|c|c|c|c|}
\hline \multirow[b]{2}{*}{ Instruments } & \multicolumn{5}{|c|}{ Who should take the lead } \\
\hline & Municipality & Province & National Govt. & EU & UN \\
\hline n & 191 & 168 & 528 & 492 & 217 \\
\hline Economic instruments & $3 \%$ & $1 \%$ & $5 \%$ & $2 \%$ & $1 \%$ \\
\hline Legislation and regulation & $21 \%$ & $24 \%$ & $32 \%$ & $35 \%$ & $23 \%$ \\
\hline Information instruments & $20 \%$ & $13 \%$ & $7 \%$ & $7 \%$ & $2 \%$ \\
\hline Partnerships & $7 \%$ & $4 \%$ & $3 \%$ & $4 \%$ & $8 \%$ \\
\hline Innovation and technology & $5 \%$ & $8 \%$ & $7 \%$ & $7 \%$ & $6 \%$ \\
\hline Future vision and goals & $21 \%$ & $35 \%$ & $33 \%$ & $38 \%$ & $47 \%$ \\
\hline Action & $23 \%$ & $15 \%$ & $12 \%$ & $7 \%$ & $12 \%$ \\
\hline Other & $1 \%$ & $0 \%$ & $1 \%$ & $1 \%$ & $2 \%$ \\
\hline
\end{tabular}

in bold top-3 (if value $>=10 \%$ )

\section{Market}

This includes business and industry and water/electricity and gas companies. This distinction is made because the latter used to be public and have been privatised in the last decades. But results are very similar for both.

Obviously, legislation and regulation is of little importance in this group. Although they might be subject to regulation, they can not create regulations. They could however, make use of voluntary regulation. What is interesting here is that again action and designing a future vision and setting goals are so important. A new element here is innovation and technology (Table 4.9).

Table 4.9: Market: importance and instruments

\begin{tabular}{lll}
\hline Instruments & $\begin{array}{l}\text { Who should take the lead } \\
\text { Business and industry }\end{array}$ & Electr/gas/Water \\
\hline $\mathbf{n}$ & 270 & 124 \\
\hline Economic instruments & $0 \%$ & $2 \%$ \\
Legislation and regulation & $3 \%$ & $2 \%$ \\
Information instruments & $3 \%$ & $6 \%$ \\
Partnerships & $6 \%$ & $5 \%$ \\
Innovation and technology & $\mathbf{3 4 \%}$ & $\mathbf{2 3 \%}$ \\
Future vision and goals & $\mathbf{2 1 \%}$ & $\mathbf{3 1 \%}$ \\
Action & $\mathbf{3 2 \%}$ & $\mathbf{2 6 \%}$ \\
Other & $\mathbf{2 \%}$ & $\mathbf{5 \%}$ \\
\hline
\end{tabular}

in bold top-3 (if value $>=10 \%$ )

\section{Civil society}

This includes the respondent her/himself, neighbourhood groups and unions or employers organisations. 
Table 4.10: Civil society: importance and instruments

\begin{tabular}{llll}
\hline \multicolumn{2}{l}{ Instruments } & \multicolumn{2}{l}{ Who should take the lead } \\
& Self & Neighbourhood group & Union/employer's organisation \\
\hline $\mathbf{n}$ & 283 & 10 & 67 \\
\hline Economic instruments & $0 \%$ & $0 \%$ & $1 \%$ \\
Legislation and regulation & $5 \%$ & $0 \%$ & $7 \%$ \\
Information instruments & $5 \%$ & $\mathbf{3 0 \%}$ & $9 \%$ \\
Partnerships & $3 \%$ & $\mathbf{1 0 \%}$ & $\mathbf{1 2 \%}$ \\
Innovation and technology & $3 \%$ & $0 \%$ & $10 \%$ \\
Future vision and goals & $\mathbf{1 2 \%}$ & $\mathbf{1 0 \%}$ & $\mathbf{3 4 \%}$ \\
Action & $\mathbf{6 9 \%}$ & $\mathbf{5 0 \%}$ & $\mathbf{2 5 \%}$ \\
Other & $\mathbf{2 \%}$ & $0 \%$ & $0 \%$ \\
\hline
\end{tabular}

in bold top-3 (if value $>=10 \%$ )

We see that the answers are less homogeneous than in the previous tables. First of all, neighbourhood groups are not seen as very important with only 10 respondents. Maybe they are not well known. Interestingly, people themselves see that it is important that they take action. As in the previous stakeholder clusters, designing future visions and setting goals are seen as important instruments. Partnerships are also mentioned as important ways to realise sustainable development. The most important instrument seems to be taking action (Table 4.10).

\section{Research and education}

Research and education have been made into a specific cluster, although one could argue science and education are part of civil society, or are funded by government and therefore should be in that group. However, science and education have special roles to play in generating and providing information and knowledge to all groups in society, which justifies a separate cluster.

Interestingly, education (as in schools) is not seen as an important player to take the lead in sustainable development, with only 68 respondents choosing this option. However, schools score high with information instruments. Innovation and technology is seen as especially important for research. Action is not seen as important for research, but it is an instrument in the top-3 for education. Again, as in all previous stakeholder clusters, setting a future vision and goals, as well as action are seen as important instruments for sustainable development (Table 4.11). 
Table 4.11: Research and education: importance and instruments

\begin{tabular}{lll}
\hline Instruments & Who should take the lead & \\
\hline $\mathbf{n}$ & Education & Research \\
\hline Economic instruments & 68 & 145 \\
Legislation and regulation & $0 \%$ & $0 \%$ \\
Information instruments & $0 \%$ & $1 \%$ \\
Partnerships & $\mathbf{4 9 \%}$ & $8 \%$ \\
Innovation and technology & $0 \%$ & $3 \%$ \\
Future vision and goals & $\mathbf{1 5 \%}$ & $\mathbf{6 2 \%}$ \\
Action & $\mathbf{1 5 \%}$ & $\mathbf{2 1 \%}$ \\
Other & $\mathbf{2 1 \%}$ & $3 \%$ \\
\hline
\end{tabular}

in bold top-3 (if value >=10\%)

\subsubsection{Implications}

Sustainable development is an issue for everyone. This we derive from the fact every sector is expected to contribute to sustainable development by at least taking action and providing a future vision and goals (Table 4.12).

Table 4.12: Overview of instruments per actor

\begin{tabular}{|c|c|c|c|c|}
\hline Instruments & State & Market & Society & Research and education \\
\hline \multicolumn{5}{|l|}{ Economic instruments } \\
\hline \multirow{4}{*}{$\begin{array}{l}\text { Legislation and regulation } \\
\text { Information instruments } \\
\text { Partnerships } \\
\text { Innovation and technology }\end{array}$} & $x$ & & & \\
\hline & \multicolumn{4}{|r|}{$x$} \\
\hline & \multicolumn{4}{|c|}{$x$} \\
\hline & & $X$ & & $x$ \\
\hline \multirow{2}{*}{$\begin{array}{l}\text { Future vision and goals } \\
\text { Action }\end{array}$} & $x$ & $\mathrm{X}$ & $\mathrm{X}$ & $x$ \\
\hline & $x$ & $\mathrm{x}$ & $x$ & $x$ \\
\hline
\end{tabular}

The preference for government to take the lead lies mainly in the field of creating an enabling environment through regulation, legislation, information and, something that has not been mentioned here, coordination. Respondents favour national and supra-national levels. However, it is doubtful if these levels are the most suitable. Maybe these levels are most visible for the respondents in the media and that is why they were chosen. Another option is that respondents acknowledge intuitively the complex and transboundary nature of sustainable development, which can be addressed better at higher levels. A third option, which is also mentioned in the 2010 Population Survey of Limburg (Province of Limburg, 2010a), is that there is a mismatch between expectations of people and actual tasks of the province.

What is interesting is that for every player different strengths and roles are pinpointed. According to the respondents, government should bring in regulation and 
legislation, business and research should take care of innovation and technology, civil society should form partnerships and education provides information.

Coming back to the vision and goals, we have seen in the previous chapter that this is a weak point in sustainable development strategies and thus is definitely an area of concern.

\subsection{Conclusion}

In this chapter we aimed to find out more about the knowledge and behaviour of the Limburg population regarding sustainable development. The idea was that there might be a limited understanding of sustainable development which is a barrier to implementation. At the same time, it was thought that people might be "doing" sustainable development without knowing it, which would make a transition towards sustainable development more an issue of labelling then of behavioural change. Furthermore, we wanted to know who should take the lead in sustainable development and how. The aim was to get a picture of people's expectations of the various actors in sustainable development. Three hypotheses and one question were formulated:

- sustainable development is not well known

- sustainable development is understood mainly as environment

- people show sustainable behaviour, but don't always call it that

- who should take the lead in sustainable development and how should that be done?

The major conclusions are that regarding hypotheses 1 and 2 people understand sustainable development at an abstract level, but interpret it as environment at a concrete level. People think sustainable development is important. Economy is not seen as a significant dimension of sustainable development.

Regarding the third hypothesis people say they are sustainable and want to become even more sustainable, but they do not act sustainable (yet). Their behaviour is mainly driven by quality and cost considerations.

Regarding item four, people see government as the most important player to take the lead in sustainable development, but they see a role for the other players too. Vision and goal formulation is seen as the most important instrument, followed by taking action.

This chapter reveals some interesting facts: People think sustainable development is important. However, there is limited understanding of sustainable development at the level of concrete actions, limited action currently undertaken, and a preference for government to take action. But, this chapter also shows many opportunities for improvement. 
First of all, it is clear that information is needed on sustainable development. More specifically, people need to know about the interrelatedness of the social, environmental and economical domains and time and space. Furthermore, they need information on the individual benefits, effects of sustainable behaviour and examples of concrete actions they can take.

Secondly, actions that people take can be made more sustainable by making the sustainable options the easiest ones, providing product information, helping people to determine the sustainability of their actions, offering alternative mobility solutions that ensure speed and accessibility and making private transport more expensive.

Thirdly, an enabling environment can be created that helps these changes along. Because government is seen to be so important and because sustainable development is such a long term affair, government seems to be ideally placed to coordinate the creation of an enabling environment. Furthermore, government should develop a vision, set goals, take action an provide legislation and regulation. Visions, goals and actions are important for all actors. However, each party is also expected to play specific roles.

In general it has become clear that certain groups need to be approached specifically dependent on age, gender, education and company size.

It is important to note that the three clusters of providing information, stimulating action and creating an enabling environment are interrelated and mutually reinforcing and therefore should be addressed in parallel. 


\section{Annex 4.1: Survey questions (in Dutch)}

\section{Bent $u$ bekend met het begrip Duurzame ontwikkeling?}

○ ja

nee (door naar definitie)

2a. Kunt u hieronder kort omschrijven waar u aan denkt bij het begrip Duurzame ontwikkeling?

2b. Hieronder staat een aantal onderwerpen. Aan welk(e) onderwerp(en) denkt $u$ als $u$ iets hoort of leest over Duurzame ontwikkeling? (meerdere antwoorden mogelijk)

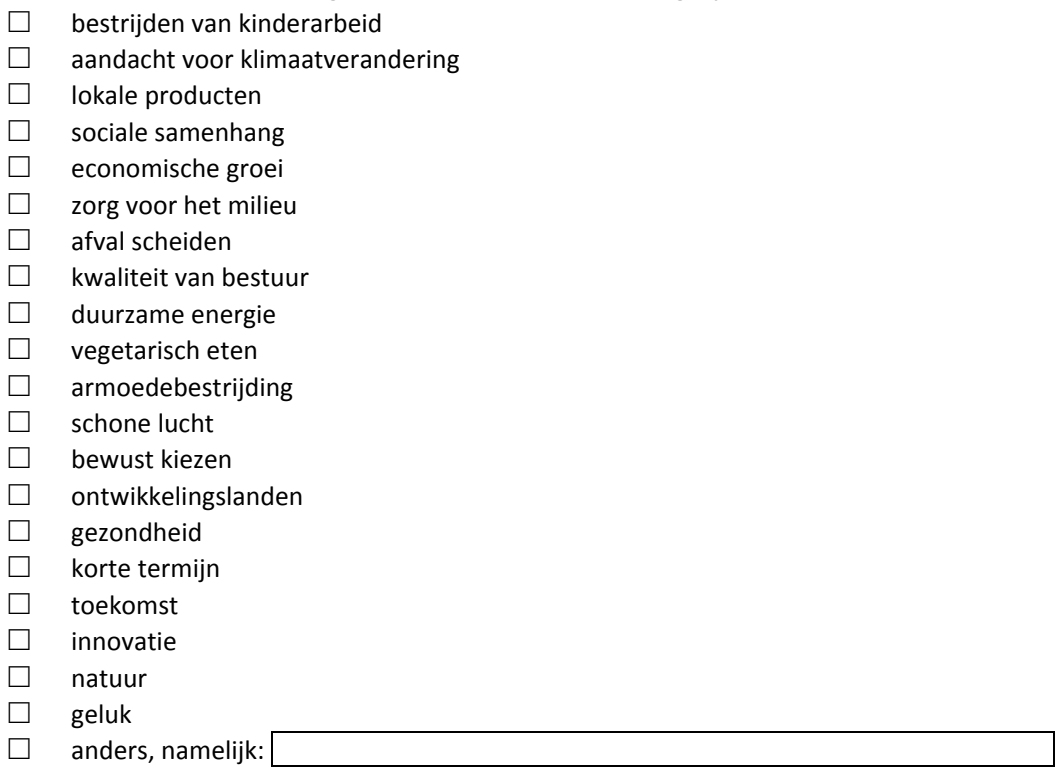

3. Welke van onderstaande beschrijvingen geeft voor $u$ het begrip 'duurzame ontwikkeling' het beste weer? (Let op: slechts één antwoord mogelijk)

ontwikkeling of oplossing die het lang volhoudt

ontwikkeling die van goede kwaliteit is

ontwikkeling met aandacht voor het milieu

$\bigcirc$ evenwichtige ontwikkeling van milieu, samenleving en economie samen

$\bigcirc$ ontwikkeling naar een leefbare toekomst

$\bigcirc$ ontwikkeling van de kwaliteit van leven

weloverwogen ontwikkeling

$\bigcirc$ ontwikkeling van een veerkrachtige samenleving

\section{Definitie}

In dit onderzoek wordt de volgende definitie van duurzame ontwikkeling gehanteerd:

Duurzame ontwikkeling gaat over de kwaliteit van leven die wij als samenleving willen bereiken. Dit betekent dat de ontwikkelingen of vooruitgang in een bepaald domein (sociaal, milieu, economie) niet ten koste gaan van andere domeinen, en dat toekomstige generaties of mensen op andere plaatsen in de wereld geen nadelige gevolgen van onze acties hebben. Ook anderen, elders en in de toekomst, hebben het recht op kwaliteit van leven.

Deze info wordt beschikbaar als INFO button bij de verschillende vragen. 
4a. Wie zou volgens u het voortouw moeten nemen bij duurzame ontwikkeling? (maximaal 3 antwoorden mogelijk)

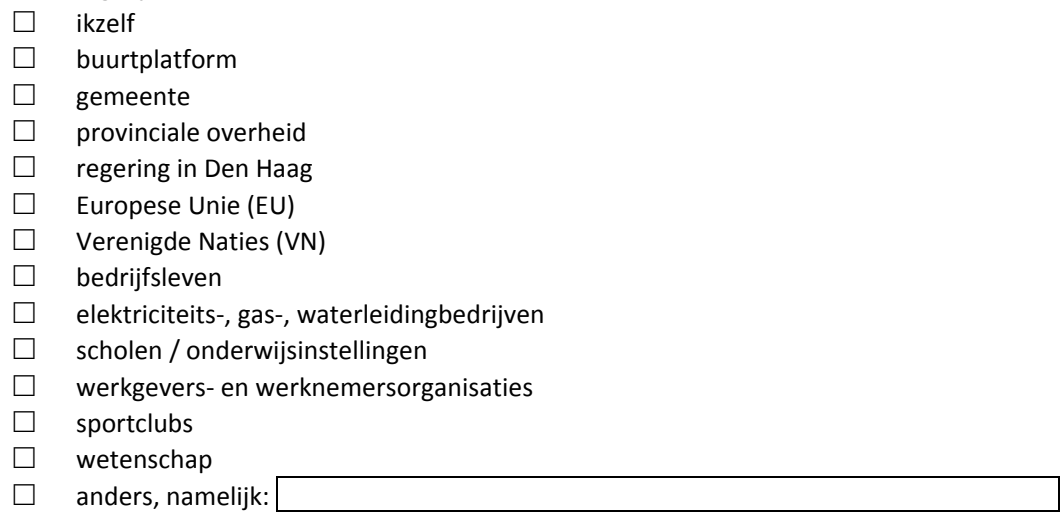

Vraag 4b voor elk van de gekozen opties; vraagstelling van 4b tekstueel wordt aangepast aan 4a.

4b. Op welke manier zou <antwoord vraag 4a> volgens u het voortouw moeten nemen bij duurzame ontwikkeling? (kies de manier die $u$ het belangrijkst vindt)

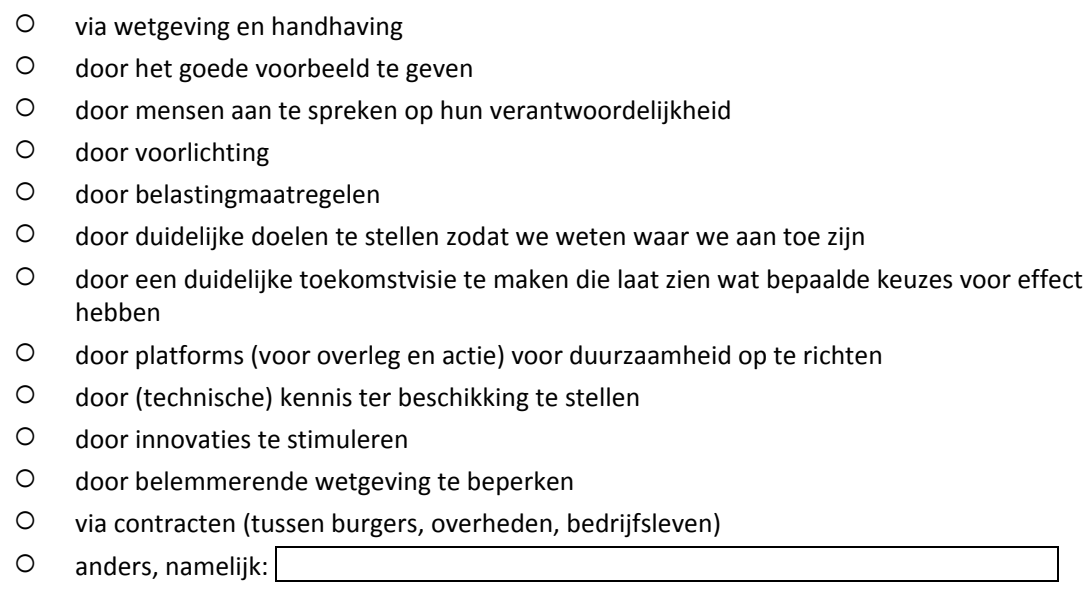

\section{Duurzame ontwikkeling binnen uw huishouden}

5. Welke van onderstaande activiteiten zijn in de afgelopen 6 maanden binnen uw huishouden uitgevoerd? Kunt u ook aangeven wie het meest / het vaakst verantwoordelijk was voor het besluiten over de uitvoering van de activiteit?

\begin{tabular}{|l|c|c|c|c|}
\hline & ikzelf & $\begin{array}{c}\text { iemand anders } \\
\text { in mijn huis- } \\
\text { houden }\end{array}$ & $\begin{array}{c}\text { ikzelf in overleg met } \\
\text { iemand anders in } \\
\text { mijn huishouden }\end{array}$ & $\begin{array}{c}\text { niet uit- } \\
\text { gevoerd }\end{array}$ \\
\hline sportclub kiezen & 0 & 0 & 0 & 0 \\
\hline doen van boodschappen & 0 & 0 & 0 & 0 \\
\hline kleding kopen & 0 & 0 & 0 & 0 \\
\hline $\begin{array}{l}\text { elektrische apparatuur kopen (bijv. een } \\
\text { computer, koelkast, stereo, TV, wasma- } \\
\text { chine, etc.) }\end{array}$ & 0 & 0 & 0 & 0 \\
\hline auto kopen & 0 & 0 & 0 & 0 \\
\hline
\end{tabular}




\begin{tabular}{|l|c|c|c|c|}
\hline kiezen van een vakantiebestemming & 0 & 0 & 0 & 0 \\
\hline energiebedrijf kiezen & 0 & 0 & 0 & 0 \\
\hline afval scheiden of hergebruik & 0 & 0 & 0 & 0 \\
\hline $\begin{array}{l}\text { reparaties uitvoeren / klussen / renova- } \\
\text { tie }\end{array}$ & 0 & 0 & 0 & 0 \\
\hline $\begin{array}{l}\text { inrichten van uw huis (geheel of ge- } \\
\text { deeltelijk) }\end{array}$ & 0 & 0 & 0 & 0 \\
\hline bouw van uw huis & 0 & 0 & 0 & 0 \\
\hline ontwerpen van uw huis & 0 & 0 & 0 & 0 \\
\hline
\end{tabular}

De met keuze 1 of 2 beantwoorde activiteiten bepalen routing naar volgende vragen.

$6 a$ en 6 b worden herhaald voor elk van de gekozen activiteiten (optie 1,2 of 3)

Als volgt opgenomen in vraag $6 a$ en $6 \mathrm{~b}$ :

- de keuze van een sportclub

- het boodschappen doen

- de aankoop van kleding

- de aankoop van elektrische apparatuur

- de aankoop van een auto

- $\quad$ het kiezen van een vakantiebestemming

- $\quad$ het kiezen van een energiebedrijf

- $\quad$ het scheiden of hergebruiken van afval

- $\quad$ het uitvoeren van reparaties of klussen of een renovatie

- $\quad$ het geheel of gedeeltelijk inrichten van uw huis

- de bouw van uw huis

- $\quad$ het ontwerpen van uw huis

6a. Welke van de onderstaande overwegingen hebben een rol gespeeld bij ? (maximaal 3 antwoorden mogelijk)

prijs / kosten

kwaliteit

belasting van het milieu

arbeidsomstandigheden bij toeleverancier / dienstverlener (denk bijv. aan kinderarbeid, veiligheid medewerkers, leefbaar loon, etc.)

$\square \quad$ inkoop- en handelsvoorwaarden bij toeleverancier / dienstverlener (denk bijv. aan eerlijke winstdeling, eerlijke contracten, misbruik van een dominante marktpositie, etc.)

$\square \quad$ anders, namelijk:

(

geen van bovenstaande

$\square$ weet ik niet

6b. Welke van de door u gekozen overweging(en) is het meest belangrijk geweest bij .....?

prijs / kosten

kwaliteit

$\bigcirc$ belasting van het milieu

$\bigcirc$ arbeidsomstandigheden bij toeleverancier / dienstverlener (denk bijv. aan kinderarbeid, veiligheid medewerkers, leefbaar loon, etc.)

○ inkoop- en handelsvoorwaarden bij toeleverancier / dienstverlener (denk bijv. aan eerlijke winstdeling, eerlijke contracten, misbruik van een dominante marktpositie, etc.)

anders, namelijk:

$\bigcirc$ geen van bovenstaande 
7a. $U$ kunt in uw huishouden op verschillende manieren een bijdrage leveren aan duurzame ontwikkeling. Kunt $u$ aangeven of in uw huishouden onderstaande manieren gebruikt worden om een bijdrage te leveren?

\begin{tabular}{|l|c|c|c|c|}
\hline & ja & nee & weet niet & n.v.t. \\
\hline $\begin{array}{l}\text { zuinig omgaan met energie (bijv. lichten of PC's uit, spaar- } \\
\text { lampen) }\end{array}$ & 0 & 0 & 0 & 0 \\
\hline zuinig omgaan met water (bijv. spaarknop op wc's) & 0 & 0 & 0 & 0 \\
\hline $\begin{array}{l}\text { zuinig omgaan met verwarming (bijv. regelbare / program- } \\
\text { meerbare thermostaten) }\end{array}$ & 0 & 0 & 0 & 0 \\
\hline $\begin{array}{l}\text { duurzaam bouwen (bijv. zonnepanelen, isolatie, FSC hout, } \\
\text { Cradle to Cradle) }\end{array}$ & 0 & 0 & 0 & 0 \\
\hline $\begin{array}{l}\text { hergebruik en afvalscheiding (bijv. van papier, plastic, } \\
\text { batterijen, kleding, etc.) }\end{array}$ & 0 & 0 & 0 & 0 \\
\hline energiezuinige apparaten kopen (A-label) & 0 & 0 & 0 & 0 \\
\hline gebruik van groene stroom & 0 & 0 & 0 & 0 \\
\hline $\begin{array}{l}\text { milieuvriendelijk gebruik van schoonmaakmiddelen (bijv. } \\
\text { middelen zonder chloor of oplosmiddelen, compact, goed } \\
\text { letten op dosering, geen spuitbussen, evt. ecolabel) }\end{array}$ & 0 & 0 & 0 & 0 \\
\hline $\begin{array}{l}\text { het niet gebruiken van gif (onkruidverdelgers, mosverwijde- } \\
\text { raars, slakkenmiddel, etc.) rond het huis }\end{array}$ & 0 & 0 & 0 & 0 \\
\hline
\end{tabular}

7b. Kunt $u$ aangeven of $u$ het eens of oneens bent met onderstaande stellingen?

\begin{tabular}{|l|c|c|c|c|}
\hline & eens & oneens & weet niet & n.v.t. \\
\hline $\begin{array}{l}\text { Mijn huishouden heeft voorlichting gekregen over } \\
\text { duurzame ontwikkeling. }\end{array}$ & 0 & 0 & 0 \\
\hline $\begin{array}{l}\text { Mijn huishouden steunt projecten in ontwikkelings- } \\
\text { landen. }\end{array}$ & 0 & 0 & 0 & 0 \\
\hline Er is natuur rondom mijn woning. & 0 & 0 & 0 & 0 \\
\hline $\begin{array}{l}\text { Medebewoners / huisgenoten worden aangespro- } \\
\text { ken op gedrag dat niet duurzaam is. }\end{array}$ & 0 & 0 & 0 & 0 \\
\hline $\begin{array}{l}\text { In mijn huishouden wordt regelmatig (3 keer of } \\
\text { meer per week) vegetarisch gegeten. }\end{array}$ & 0 & 0 & 0 & 0 \\
\hline $\begin{array}{l}\text { Mijn huishouden helpt / steunt minder kansrijke } \\
\text { mensen. }\end{array}$ & 0 & 0 & 0 & 0 \\
\hline Mijn huishouden doet mee aan buurtactiviteiten. & 0 & 0 & 0 & 0 \\
\hline $\begin{array}{l}\text { In mijn huishouden wordt nagedacht over de } \\
\text { toekomst van de wereld. }\end{array}$ & 0 & 0 & 0 & 0 \\
\hline $\begin{array}{l}\text { Mijn huishouden koopt regionale producten (bijv. } \\
\text { groente, vlees of dranken uit Limburg). }\end{array}$ & 0 & 0 & 0 & 0 \\
\hline $\begin{array}{l}\text { Mijn huishouden koopt Fair Trade producten (bijv. } \\
\text { koffie of chocolade). }\end{array}$ & 0 & 0 & 0 & 0 \\
\hline
\end{tabular}

8. In uw dagelijks leven maakt u steeds keuzes voor producten of diensten. Deze keuzes kunnen gebaseerd zijn op bepaalde productinformatie. Welke informatie is voor u belangrijk bij de keuze voor een product of dienst? Het kan hierbij onder meer gaan over voeding, kleding, bankieren, elektriciteitsbedrijf, tuinmeubels, elektrische apparatuur, etc. (meerdere antwoorden mogelijk)

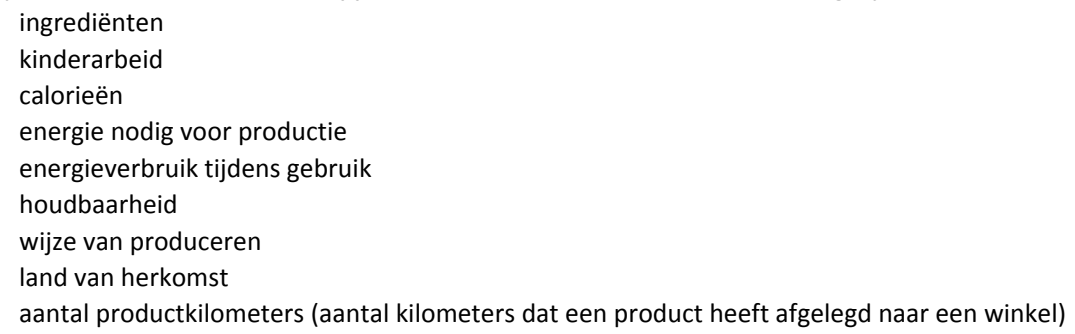


Fair Trade keurmerk

Eko keurmerk

FSC (Forest Stewardship Council) keurmerk voor hout

MSC (Marine Stewardship Council) keurmerk voor vis

anders, namelijk:

9a. Wat is het beeld dat u heeft van uw eigen levensstijl op het gebied van duurzaamheid?

$\bigcirc \quad i k$ ben voortdurend actief op zoek naar informatie over een duurzame levensstijl en nieuwe duurzame producten en probeer deze meteen uit, ik voel mij een voorloper op dit gebied

$\bigcirc \quad$ ik ben bewust bezig met een zo duurzaam mogelijke levensstijl en de keuze voor duurzame producten

$\bigcirc \quad$ ik kies alleen voor een duurzame levensstijl en duurzame producten als ik niets (extra's) hoef te doen of laten

pas als anderen kiezen voor een duurzame levensstijl en duurzame producten, en het nut hiervan duidelijk voor mij is, doe ik dat ook

i ik ben totaal niet bezig met een duurzame levensstijl of duurzame producten, ze zullen me moeten dwingen om duurzaam te worden

9b. Zou u duurzamer willen leven? (max. 1 antwoord mogelijk)

$\bigcirc \quad \mathrm{ja}$, als het geen extra moeite en geld kost

$\bigcirc \quad$ ja, zelfs als het meer geld kost

$\bigcirc \quad$ ja, zelfs als het meer moeite kost

$\bigcirc \quad$ ja, zelfs als het meer geld en moeite kost

$\bigcirc$ ja, als iedereen het doet

$\bigcirc \quad$ ja, als het een duidelijk effect heeft

○ ja, als er duidelijke informatie is over duurzaamheid

$\bigcirc$ nee, ik doe al genoeg

$\bigcirc$ nee, ik wil niet duurzamer leven

$\bigcirc$ ja, anders namelijk:

10. Kunt u hieronder kort omschrijven op welke manier u zelf duurzamer denkt te kunnen leven?

11a. Hoe belangrijk vindt u duurzame ontwikkeling in het algemeen?

$\bigcirc$ heel belangrijk

$\bigcirc$ belangrijk

niet belangrijk / niet onbelangrijk

onbelangrijk

heel onbelangrijk

11b. Hieronder kunt u uw antwoord op vraag 11a kort toelichten. 
12a. Beschikt uw huishouden over een auto? (Het gaat zowel om privé als zakelijke auto's)

$\bigcirc$ ja, 1 auto

ja, 2 of meer auto's

nee, maar in ons huishouden wordt wel af en toe een auto gehuurd of geleend

nee (door naar vraag 13a)

12b. Hoeveel kilometer werd het afgelopen jaar met de auto(s) afgelegd (totaal van alle auto's samen, ook incidenteel gehuurde of geleende auto's, zowel privé als zakelijk)?

minder dan $2.000 \mathrm{~km}$

○ $\quad 2.000$ tot $5.000 \mathrm{~km}$

○ 5.000 tot $10.000 \mathrm{~km}$

○ 10.000 tot $50.000 \mathrm{~km}$

○ $50.000 \mathrm{~km}$ of meer

o weet ik niet

12c. Waarvoor gebruikt u de auto vooral? (Let op: het gaat om de grootst afgelegde afstand per jaar en niet om gebruiksduur of -frequentie) (maximaal 3 antwoorden mogelijk)

gezelligheid / sport / recreatie in de buurt

winkelen / boodschappen / persoonlijke verzorging / afspraken in de buurt

vakantie

bezoek familie / vrienden / dagje uit

woon-werk verkeer

zakelijke afspraken

anders, namelijk:

13a. Bent u op dit moment werkzaam?

O ja, ik ben fulltime werkzaam

$\bigcirc$ ja, ik ben parttime werkzaam (minimaal 12 uur per week)

$\bigcirc$ nee, ik ben niet werkzaam of minder dan 12 uur

13b. Volgt u op dit moment een opleiding of studie?

$\bigcirc \quad$ ja, een voltijd opleiding of studie

$\bigcirc \quad$ ja, een deeltijd opleiding of studie

$\bigcirc$ nee, ik volg geen opleiding of studie

13c. Verricht u momenteel vrijwilligerswerk?

○ ja, minder dan 12 uur per week

$\bigcirc$ ja, meer dan 12 uur per week

$\bigcirc$ nee

Bovenstaande vragen bepalen routing door vragenlijst.

Werk

Hieronder volgt een aantal vragen over uw werksituatie. Indien u meerdere banen heeft, wilt $u$ dan bij het beantwoorden van de vragen uitgaan van de baan / het werk waar $u$ de meeste tijd aan besteedt, betaald of onbetaald. 
14a. Hoeveel uur werkt u per week (betaald of onbetaald)?

O minder dan 12 uur (door naar opleiding / school of naar einde afhankelijk van antwoorden)

O $12 \mathrm{t} / \mathrm{m} 20$ uur

O $21 \mathrm{t} / \mathrm{m} 32$ uur

O $33 \mathrm{t} / \mathrm{m} 40$ uur

O Meer dan 40 uur

14b. In welke bedrijfstak werkt u? (Indien u meerdere banen heeft, ga dan uit van de baan waar u de meeste tijd aan besteedt, betaald of onbetaald)

$\bigcirc \quad$ landbouw en visserij

O delfstoffenwinning (olie, gas, zand, grind, etc.)

$\bigcirc$ industrie, reparatie, installatie (vervaardiging voeding, dranken, textiel, machines, reparatie, installatie, etc.)

$\bigcirc$ energie- en waterleidingbedrijven

bouw of bouwnijverheid

○ handel

vervoer en opslag (vervoer over land, water, lucht, opslag, post en koeriers)

horeca

$\bigcirc \quad$ informatie en communicatie (uitgeverijen, TV, telefoon, ICT, etc.)

$\bigcirc$ financiële instellingen (banken, beleggers, pensioenfondsen, adviseurs, etc.)

$\bigcirc$ onroerend goed

- zakelijke dienstverlening (rechtskundig, accountancyadvies, architecten, speurwerk, reclame, verhuur roerende goederen, uitzendbureaus, reisorganisatie, schoonmaak, beveiliging, etc.)

$\bigcirc$ openbaar bestuur (overheidsdiensten, verplichte verzekeringen)

onderwijs

gezondheids- en welzijnszorg

cultuur, sport en recreatie

overige dienstverlening (hobbyclubs, politieke organisaties, levensbeschouwelijke organisaties, reparatie computers en consumentenartikelen, wellness, uitvaart, etc.)

personeel in dienst van huishoudens

internationale gemeenschapsorganen

anders, namelijk:

14c. Bent u werkgever, werknemer of zelfstandige zonder personeel (zzp-er)?

werknemer

werkgever

○ zzp-er (door naar vraag 16a)

14d. Bent u leidinggevende?

$\bigcirc$ ja, aan minder dan 10 personen

○ ja, aan 10 tot 50 personen

$\bigcirc$ ja, aan 50 of meer personen

nee

15a. Heeft het bedrijf / de organisatie waar u werkt meerdere locaties?

$\bigcirc$ ja

nee (na vraag 15b door naar 16a) 
15b. Hoeveel werknemers telt het bedrijf / de organisatie waar u werkt in totaal? (Let op: het gaat hier om het totaal aan werknemers over alle locaties samen (eventueel wereldwijd indien van toepassing). Mocht u dit niet exact weten, dan kunt u een schatting maken.)
O minder dan 10
O $10 \mathrm{t} / \mathrm{m} 49$
O $50 \mathrm{t} / \mathrm{m} 99$
O $100 \mathrm{t} / \mathrm{m} 249$
○ $250 \mathrm{t} / \mathrm{m} 999$
O $1000 \mathrm{t} / \mathrm{m} 1999$
○ 2000 of meer

15c. Hoeveel werknemers telt de locatie van het bedrijf / de organisatie waar u werkt? (Let op: het gaat hier om het totaal aan werknemers in de locatie waar u werkt. Mocht u dit niet exact weten, dan kunt u een schatting maken.)
- minder dan 10
O $10 \mathrm{t} / \mathrm{m} 49$
O $50 \mathrm{t} / \mathrm{m} 99$
○ $100 \mathrm{t} / \mathrm{m} 249$
○ $250 \mathrm{t} / \mathrm{m} 999$
○ $1000 \mathrm{t} / \mathrm{m} 1999$
○ 2000 of meer
n.v.t. het bedrijf waar ik werk heeft één locatie

16a. Welke vervoersmiddelen gebruikt u normaal gesproken om op uw werk te komen? (meerdere antwoorden mogelijk)

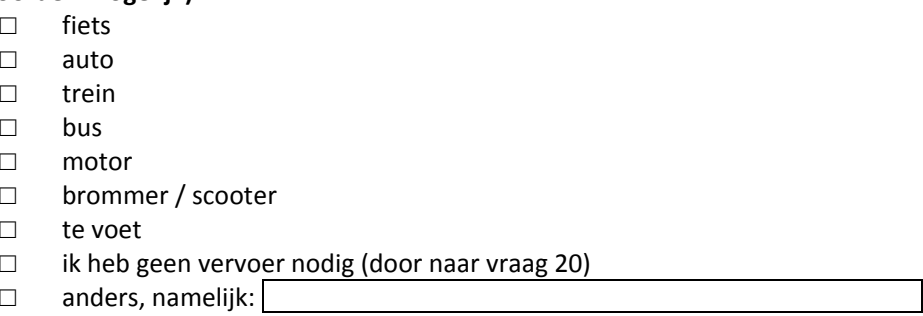

16b. Waarom kiest u voor dit vervoersmiddel of voor deze combinatie van vervoersmiddelen? (maximaal 3 antwoorden mogelijk)

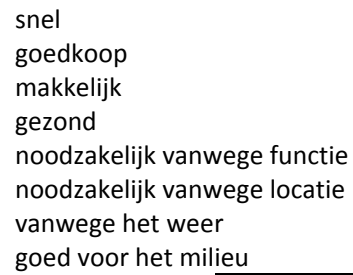


16c. Welke van onderstaande vervoersmiddelen beschouwt $u$ als meest belangrijk om op uw werk te komen?
$\bigcirc$ fiets
$\bigcirc$ auto
trein
o bus
motor
brommer / scooter
te voet
anders, namelijk:

17a. Hoe lang bent u gemiddeld onderweg naar uw werk?
$\bigcirc$ minder dan een kwartier
O een kwartier tot een half uur
een half uur tot een uur
een tot twee uur
twee uur of meer

17b. Welke afstand moet $\mathrm{u}$ afleggen om op uw werk te komen?
minder dan $5 \mathrm{~km}$
O 5 tot $10 \mathrm{~km}$
○ 10 tot $20 \mathrm{~km}$
○ 20 tot $50 \mathrm{~km}$
○ $50 \mathrm{~km}$ of meer

18. Wordt vanuit het bedrijf / de organisatie waar u op dit moment werkt het gebruik van milieuvriendelijk woon-werkverkeer gestimuleerd?
$\bigcirc$ ja
$\bigcirc$ nee
weet ik niet / n.v.t.

19. Kunt u hieronder kort beschrijven op welke manier het milieuvriendelijk woon-werkverkeer wordt gestimuleerd?

20. Wat is het beeld dat u heeft van uw bedrijf/organisatie op het gebied van duurzaamheid?

O mijn bedrijf/organisatie is voortdurend actief op zoek naar informatie over duurzaam ondernemen en nieuwe duurzame producten en probeert deze meteen uit, wij zijn een voorloper op dit gebied

- mijn bedrijf/organisatie is bewust bezig met zo duurzaam mogelijk ondernemen en de keuze voor duurzame producten

- mijn bedrijf/organisatie kiest alleen voor duurzaam ondernemen en duurzame producten als we niets (extra's) hoeven te doen of laten

o pas als andere bedrijven/organisaties kiezen voor duurzaam ondernemen en duurzame producten, en het nut hiervan duidelijk is, doen wij dat ook

- mijn bedrijf/organisatie is totaal niet bezig met duurzaam ondernemen of duurzame producten, ze zullen ons moeten dwingen om duurzaam te worden 


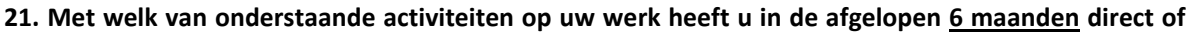
indirect te maken gehad?

(Let op: direct wil zeggen dat u er zelf mee te maken heeft gehad of de beslissing hierover heeft genomen; indirect wil zeggen dat iemand anders op uw werk ermee te maken heeft gehad of dat iemand anders de beslissing hierover heeft genomen.)

\begin{tabular}{|c|c|c|c|c|}
\hline & $\begin{array}{l}\text { direct } \\
\text { mee te } \\
\text { maken } \\
\text { gehad }\end{array}$ & $\begin{array}{l}\text { indirect } \\
\text { mee te } \\
\text { maken } \\
\text { gehad }\end{array}$ & $\begin{array}{l}\text { niet mee te maken } \\
\text { gehad / niet van } \\
\text { toepassing in mijn } \\
\text { bedrijf }\end{array}$ & $\begin{array}{l}\text { weet } \\
\text { ik niet }\end{array}$ \\
\hline $\begin{array}{l}\text { inkoop van diensten (bijv. ICT/IT, admini- } \\
\text { stratief, etc.) }\end{array}$ & 0 & 0 & 0 & 0 \\
\hline \multicolumn{5}{|l|}{$\begin{array}{l}\text { inkoop van grondstoffen (zaken nodig } \\
\text { voor productieproces, bijv. verf voor } \\
\text { schilder, olie voor chemische industrie, } \\
\text { bouwmateriaal voor bouwonderneming) }\end{array}$} \\
\hline $\begin{array}{l}\text { inkoop van niet-elektrische producten } \\
\text { (bijv. papier, onderdelen, bedrijfskleding, } \\
\text { schrijfmateriaal, schoonmaakmiddel, verf, } \\
\text { etc.) }\end{array}$ & 0 & 0 & 0 & o \\
\hline $\begin{array}{l}\text { inkoop van elektrische producten (bijv. } \\
\text { computer, koelkast, machines, etc.) }\end{array}$ & 0 & 0 & 0 & 0 \\
\hline inkoop van bedrijfsauto's & $\mathrm{o}$ & 0 & o & o \\
\hline inkoop van energie & o & o & o & o \\
\hline $\begin{array}{l}\text { afvalverwerking (afvalscheiding, afval } \\
\text { ophalen) }\end{array}$ & o & o & 0 & o \\
\hline dienstreizen & o & o & o & o \\
\hline $\begin{array}{l}\text { reparaties (bijv. aan computers, bedrijfs- } \\
\text { auto's, apparatuur, het gebouw, het } \\
\text { sanitair, etc.) }\end{array}$ & 0 & 0 & 0 & 0 \\
\hline $\begin{array}{l}\text { inhuren van catering (incidenteel of } \\
\text { permanent, zoals kantine) }\end{array}$ & 0 & 0 & 0 & 0 \\
\hline inrichting van gebouw / bedrijfspand & o & o & o & o \\
\hline ontwerp van gebouw / bedrijfspand & 0 & 0 & 0 & o \\
\hline renovatie van gebouw / bedrijfspand & 0 & 0 & o & o \\
\hline bouwen van gebouw / bedrijfspand & o & o & 0 & o \\
\hline schoonmaak van gebouw / bedrijfsruimtes & o & o & o & o \\
\hline
\end{tabular}

De met keuze 1 of 2 beantwoorde activiteiten bepalen routing naar volgende vragen.

$22 \mathrm{a}$ en $22 \mathrm{~b}$ worden herhaald voor elk van de gekozen activiteiten (optie 1 of 2 )

Als volgt opgenomen in vraag $22 \mathrm{a}$ en $22 \mathrm{~b}$ :

- $\quad$ de inkoop van diensten (bijv. ICT/IT, administratief, etc.)

- $\quad$ inkoop van grondstoffen (zaken nodig voor productieproces, bijv. verf voor schilder, olie voor chemische industrie, bouwmateriaal voor bouwonderneming)

- de inkoop van niet-elektrische producten (bijv. papier, onderdelen, bedrijfskleding, schrijfmateriaal, schoonmaakmiddel, verf, etc.)

- $\quad$ de inkoop van elektrische producten (bijv. computer, koelkast, machines, etc.)

- $\quad$ de inkoop van bedrijfsauto's

- de inkoop van energie

- $\quad$ afvalverwerking (afvalscheiding, afval ophalen)

- dienstreizen

- $\quad$ reparaties (bijv. aan computers, bedrijfsauto's, apparatuur, het gebouw, het sanitair, etc.) 
- $\quad$ het inhuren van catering (incidenteel of permanent, zoals kantine)

- de inrichting van het gebouw/bedrijfspand

- $\quad$ het ontwerp van het gebouw/bedrijfspand

- renovatie van het gebouw/bedrijfspand

- de bouw van het gebouw / bedrijfspand

- de schoonmaak van het gebouw/bedrijfsruimtes

22a. Welke van de onderstaande overwegingen hebben een rol gespeeld bij antwoorden mogelijk)

? (maximaal 3

prijs / kosten

kwaliteit

belasting van het milieu

arbeidsomstandigheden bij toeleverancier / dienstverlener (denk bijv. aan kinderarbeid, veiligheid medewerkers, leefbaar loon, etc.)

inkoop- en handelsvoorwaarden bij toeleverancier / dienstverlener (denk bijv. aan eerlijke winstdeling, eerlijke contracten, misbruik van een dominante marktpositie, etc.)

regels van het bedrijf / de organisatie, zoals:

anders, namelijk:

geen van bovenstaande

weet ik niet

22b. Welke van de door u gekozen overweging(en) is het meest belangrijk geweest bij .....?

$\bigcirc$ prijs / kosten

- kwaliteit

belasting van het milieu

$\bigcirc$ arbeidsomstandigheden bij toeleverancier / dienstverlener (denk bijv. aan kinderarbeid, veiligheid medewerkers, leefbaar loon, etc.)

○ inkoop- en handelsvoorwaarden bij toeleverancier / dienstverlener (denk bijv. aan eerlijke winstdeling, eerlijke contracten, geen misbruik van een dominante marktpositie, etc.)

regels van het bedrijf / de organisatie, zoals:

anders, namelijk:

geen van bovenstaande

23a. Het bedrijf / de organisatie waar u werkt, kan op verschillende manieren een bijdrage leveren aan duurzame ontwikkeling. Kunt $u$ aangeven of onderstaande manieren in uw bedrijf / de organisatie worden gebruikt om een bijdrage te leveren?

\begin{tabular}{|l|c|c|c|c|}
\hline & ja & nee & weet niet & n.v.t. \\
\hline $\begin{array}{l}\text { zuinig omgaan met energie (bijv. instructie om lichten of } \\
\text { PC's uit te doen, spaarlampen, productieproces energiezui- } \\
\text { nig) }\end{array}$ & 0 & 0 & 0 & 0 \\
\hline $\begin{array}{l}\text { zuinig omgaan met water (bijv. spaarknop op wc's, water- } \\
\text { zuinig productieproces) }\end{array}$ & 0 & 0 & 0 & 0 \\
\hline $\begin{array}{l}\text { zuinig omgaan met verwarming (bijv. regelbare / program- } \\
\text { meerbare thermostaten) }\end{array}$ & 0 & 0 & 0 & 0 \\
\hline $\begin{array}{l}\text { duurzaam bouwen (bijv. zonnepanelen, isolatie, FSC hout, } \\
\text { Cradle to Cradle) }\end{array}$ & 0 & 0 & 0 & 0 \\
\hline $\begin{array}{l}\text { hergebruik en afvalscheiding (bijv. van papier, plastic, } \\
\text { batterijen, kleding, etc.) }\end{array}$ & 0 & 0 & 0 & 0 \\
\hline energiezuinige apparaten kopen (A-label) & 0 & 0 & 0 & 0 \\
\hline gebruik van groene stroom & 0 & 0 & 0 & 0 \\
\hline $\begin{array}{l}\text { milieuvriendelijk gebruik van schoonmakmiddelen (bijv. } \\
\text { middelen zonder chloor of oplosmiddelen, compact, goed }\end{array}$ & 0 & 0 & 0 & 0 \\
\hline
\end{tabular}




\begin{tabular}{|l|c|c|c|c|}
\hline letten op dosering, geen spuitbussen, evt. ecolabel) & & & & \\
\hline $\begin{array}{l}\text { het niet gebruiken van gif (onkruidverdelgers, mosverwijde- } \\
\text { raars, slakkenmiddel, etc.) rond het bedrijf / de organisatie }\end{array}$ & 0 & 0 & 0 & 0 \\
\hline
\end{tabular}

23b. Kunt $u$ aangeven of $u$ het eens of oneens bent met onderstaande stellingen?

\begin{tabular}{|l|c|c|c|c|}
\hline \multicolumn{2}{|c|}{ eens } & oneens & weet niet & n.v.t. \\
\hline $\begin{array}{l}\text { Op mijn werk wordt voorlichting gegeven over } \\
\text { duurzame ontwikkeling. }\end{array}$ & 0 & 0 & 0 \\
\hline $\begin{array}{l}\text { Mijn bedrijf / organisatie steunt projecten in } \\
\text { ontwikkelingslanden. }\end{array}$ & 0 & 0 & 0 \\
\hline $\begin{array}{l}\text { Het productieproces is opgezet met aandacht voor } \\
\text { duurzame ontwikkeling. }\end{array}$ & 0 & 0 & 0 & 0 \\
\hline Er is natuur rondom mijn werk. & 0 & 0 & 0 & 0 \\
\hline $\begin{array}{l}\text { Collega's / werknemers worden aangesproken op } \\
\text { gedrag dat niet duurzaam is. }\end{array}$ & 0 & 0 & 0 & 0 \\
\hline $\begin{array}{l}\text { Mijn bedrijf / organisatie stelt ook minderheden } \\
\text { aan. }\end{array}$ & 0 & 0 & 0 & 0 \\
\hline $\begin{array}{l}\text { Mijn bedrijf / organisatie doet mee aan buurtactivi- } \\
\text { teiten. }\end{array}$ & 0 & 0 & 0 & 0 \\
\hline $\begin{array}{l}\text { In mijn bedrijf / organisatie wordt nagedacht over } \\
\text { de toekomst van de wereld. }\end{array}$ & 0 & 0 & 0 & 0 \\
\hline In de bedrijfskantine kun je vegetarisch eten. & 0 & 0 & 0 & 0 \\
\hline $\begin{array}{l}\text { In de bedrijfskantine zijn Fair Trade producten } \\
\text { beschikbaar (bijv. koffie of chocolade). }\end{array}$ & 0 & 0 & 0 & 0 \\
\hline $\begin{array}{l}\text { Mijn bedrijf / organisatie heeft een duurzaam- } \\
\text { heidsplan. }\end{array}$ & 0 & 0 & 0 & 0 \\
\hline
\end{tabular}

\section{School of onderwijsinstelling}

24a. Welke vervoersmiddelen gebruikt u normaal gesproken om op uw school / onderwijsinstelling te komen? (meerdere antwoorden mogelijk)

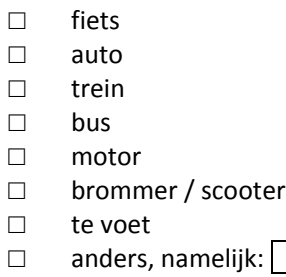

24b. Waarom kiest u voor dit vervoersmiddel of voor deze combinatie van vervoersmiddelen? (maximaal 3 antwoorden mogelijk)

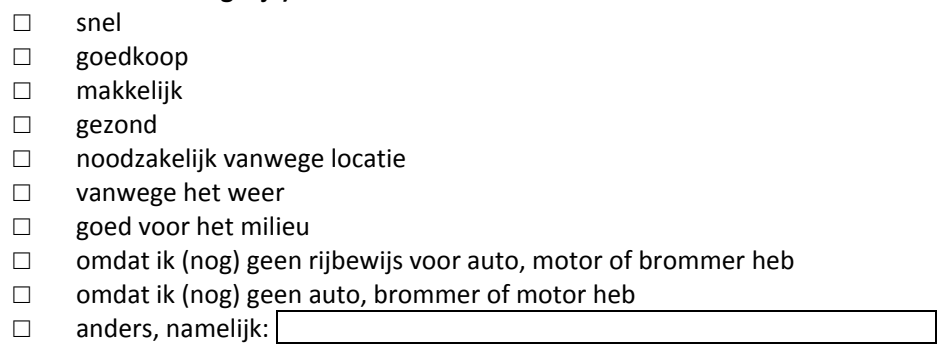


24c. Welke van onderstaande vervoersmiddelen beschouwt u als meest belangrijk om op uw school / onderwijsinstelling te komen?
$\bigcirc$ fiets
O auto
trein
bus
motor
brommer / scooter
o te voet
anders, namelijk:

25a. Hoe lang bent u gemiddeld onderweg naar uw school / onderwijsinstelling?
$\bigcirc$ minder dan een kwartier
O een kwartier tot een half uur
$\bigcirc$ een half uur tot een uur
een tot twee uur
twee uur of meer

25b. Welke afstand moet u afleggen om op uw school / onderwijsinstelling te komen?
minder dan $5 \mathrm{~km}$
○ 5 tot $10 \mathrm{~km}$
○ 10 tot $20 \mathrm{~km}$
○ 20 tot $50 \mathrm{~km}$
○ $50 \mathrm{~km}$ of meer

26. Wordt vanuit uw school / onderwijsinstelling het gebruik van een milieuvriendelijke manier van vervoer naar uw school / onderwijsinstelling gestimuleerd?
○ ja
nee
weet ik niet / n.v.t.

27. Kunt u hieronder kort beschrijven op welke manier het milieuvriendelijke vervoer wordt gestimuleerd?

28a. Uw school / onderwijsinstelling kan op verschillende manieren een bijdrage leveren aan duurzame ontwikkeling. Kunt $u$ aangeven of onderstaande manieren op uw school / onderwijsinstelling worden gebruikt om een bijdrage te leveren?

\begin{tabular}{|l|c|c|c|c|}
\hline $\begin{array}{l}\text { zuinig omgaan met energie (bijv. instructie om lichten of } \\
\text { PC's uit te doen, spaarlampen) }\end{array}$ & ja & nee & weet niet & n.v.t. \\
\hline zuinig omgaan met water (bijv. spaarknop op wc's) & 0 & 0 & 0 & 0 \\
\hline $\begin{array}{l}\text { zuinig omgaan met verwarming (bijv. regelbare / program- } \\
\text { meerbare thermostaten) }\end{array}$ & 0 & 0 & 0 & 0 \\
\hline $\begin{array}{l}\text { duurzaam bouwen (bijv. zonnepanelen, isolatie, FSC hout, } \\
\text { Cradle to Cradle) }\end{array}$ & 0 & 0 & 0 & 0 \\
\hline $\begin{array}{l}\text { hergebruik en afvalscheiding (bijv. van papier, plastic, } \\
\text { batterijen, kleding, etc.) }\end{array}$ & 0 & 0 & 0 & 0 \\
\hline energiezuinige apparaten kopen (A-label) & 0 & 0 & 0 & 0 \\
\hline gebruik van groene stroom & 0 & 0 & 0 & 0 \\
\hline
\end{tabular}


milieuvriendelijk gebruik van schoonmaakmiddelen (bijv. middelen zonder chloor of oplosmiddelen, compact, goed letten op dosering, geen spuitbussen, evt. ecolabel) het niet gebruiken van gif (onkruidverdelgers, mosverwijderaars, slakkenmiddel, etc.) rond mijn school / onderwijsinstelling

\begin{tabular}{|l|l|l|l|}
\hline 0 & 0 & 0 & 0 \\
\hline 0 & 0 & 0 & 0 \\
\hline
\end{tabular}

28b. Kunt $u$ aangeven of $u$ het eens of oneens bent met onderstaande stellingen?

\begin{tabular}{|l|c|c|c|c|}
\hline & eens & oneens & weet niet & n.v.t. \\
\hline $\begin{array}{l}\text { Op mijn school / onderwijsinstelling wordt voorlich- } \\
\text { ting gegeven over duurzame ontwikkeling. }\end{array}$ & 0 & 0 & 0 \\
\hline $\begin{array}{l}\text { Mijn school / onderwijsinstelling steunt projecten in } \\
\text { ontwikkelingslanden. }\end{array}$ & 0 & 0 & 0 & 0 \\
\hline Er is natuur rondom mijn school / onderwijsinstelling. & 0 & 0 & 0 & 0 \\
\hline $\begin{array}{l}\text { Leerlingen worden aangesproken op gedrag dat niet } \\
\text { duurzaam is. }\end{array}$ & 0 & 0 & 0 & 0 \\
\hline $\begin{array}{l}\text { Op mijn school / onderwijsinstelling werken ook } \\
\text { minderheden. }\end{array}$ & 0 & 0 & 0 & 0 \\
\hline $\begin{array}{l}\text { Mijn school / onderwijsinstelling doet mee aan } \\
\text { buurtactiviteiten. }\end{array}$ & 0 & 0 & 0 & 0 \\
\hline $\begin{array}{l}\text { Op mijn school / onderwijsinstelling wordt nagedacht } \\
\text { over de toekomst van de wereld. }\end{array}$ & 0 & 0 & 0 & 0 \\
\hline In de kantine kun je vegetarisch eten. & 0 & 0 & 0 & 0 \\
\hline $\begin{array}{l}\text { In de kantine zijn Fair Trade producten beschikbaar } \\
\text { (bijv. koffie of chocolade). }\end{array}$ & 0 & 0 & 0 & 0 \\
\hline Mijn school heeft een duurzaamheidsplan. & 0 & 0 & 0 & 0 \\
\hline
\end{tabular}




\section{Implementing sustainable development: Lessons from two case studies in Limburg}

\subsection{Introduction}

Implementation of sustainable development is a challenge. In the previous chapters the different modes of governance and perspectives on sustainable development were explored, followed by investigations of the policy context at different scale levels. The thoughts and actions of the Limburg population on sustainable development revealed some barriers and opportunities. This chapter deals with the barriers to realising sustainable development in current sustainable development projects in Limburg, and also investigates what role different modes of governance play? Two case studies in Limburg are investigated: Greenport Venlo and the programme Learning for Sustainable development in Limburg. These cases were chosen because of their different modes of governance towards regional (sustainable) development. Greenport Venlo is a voluntary network organisation that aims at regional development, involving a multitude of stakeholders. Learning for sustainable development is a government subsidised programme to stimulate more sustainable development in the region by giving grants to educational projects. Both cases have evolved in a different way and are characterised by different modes of governance. The Greenport Venlo (GV) case is characterised by deliberation, while the case of Learning for Sustainable Development (LvDO) case follows a more traditional top down approach.

This chapter will zoom in on differences and similarities between both cases in order to learn more about current problems and practices. In the present analysis the theoretical framework of chapter 2 is used to find out what the impact is of different modes of governance and different perspectives on sustainable development on the type of problems that occur and the practices used. Therefore, specific research questions in this chapter are:

- What problems occurred in Greenport Venlo (GV) and Learning for sustainable development (LvDO)?

- What practices, i.e. solutions to problems, actions, did practitioners use to implement sustainable development?

- What are the differences and similarities between GV and LvDO regarding problems and practices? 
- What lessons can we draw regarding the mode of governance and the perspective on sustainable development in both cases and the problems and practices observed?

It is interesting to compare two cases that have different modes of governance. In literature it is often said that traditional governance is not suited for dealing with sustainable development due to its wicked nature, its multi-level, multi-actor and multi-sector character (Kellerman, 2006; Meuleman and in 't Veld, 2009; Noordegraaf and van Lierop, 2006; Termeer and Kranendonk, 2008). To a greater or lesser extent network governance or horizontal governance is propagated, although the old forms of governance should not be thrown away. A mix of governance modes might be more appropriate (Collins et al., 2003; Meuleman and in 't Veld, 2009; Termeer and Kranendonk, 2008; Termeer, 2008). New roles for government are thought to lie in the field of facilitating, coordinating, mediating, partnering and guiding (Aarts and Grin, 2006; Kellerman, 2006; Meuleman and in 't Veld, 2009; Termeer and Kranendonk, 2008). This is linked to specific personal skills of facilitators that are needed to deal with sustainable development, but that are not always present in government institutions such as participatory techniques, facilitation skills, mediation (Kellerman, 2006; Lamers et al., 2010; van der Woude, 2008). A clear identification of the roles of various participants is important precisely because of the multitude of actors involved (Lamers et al., 2010; Meuleman and in ' $t$ Veld, 2009) as well as an integrated approach to fully appreciate the meaning of sustainable development in society (Aarts and Grin, 2006; Kellerman, 2006; van der Woude, 2008). Lastly, moments for reflection are seen as important elements of adapting governance towards new developments and to learn from the past (Aarts and Grin, 2006; Lamers et al., 2010). We will see in the next parts if, and how, some of these themes also appear in the two cases.

\subsection{Background of the case studies}

\subsubsection{Learning for sustainable development (LVDO)}

The programme Learning for sustainable development (LVDO) is a national programme. It started as Learning for Sustainability (LvD) in 2000, which was the continuation of government education programmes in the field of nature and environment. The first track of LvDO (2004-2007), which is investigated here, was developed in the light of the national action programme for sustainable development (2003), the Plan of Implementation of the WSSD (2002) and the UN decade for education for sustainable development (2005-2015) (LvDO, 2003; Province of Limburg, 2004; UN, 2002). A major finding in the earlier LvD programme was that sustainability efforts do not operate in the mainstream of society, but rather in the margin. That is why the 2004-2007 programme was called "from the margin to 
mainstream" (LvDO, 2003). The aim of the programme was to start effective learning processes among social actors focusing on considerations for sustainable development. The idea was that actors would obtain knowledge, find a drive and get the skills to contribute to sustainable development. The programme had three pillars: learning individuals that stimulated the supply of learning possibilities. The focus was mainly on activities within educational institutions. Learning organisations was meant to include sustainable development in decision-making processes within government institutions or services at all levels, from local to national. Learning society aimed at improving reflection and dialogue about sustainable development in society by means of projects (LvDO, 2003).

The LVDO programme was commissioned by Parliament. A Steering Group was, in the period this research was conducted, chaired by the Ministry of Agriculture, Nature and Food Quality and consists of representatives of the Ministry of Housing, Spatial Planning and the Environment, the Ministry of Development Cooperation, The Ministry of Economic Affairs, the Ministry of Education, Culture and Science, The Ministry of Transport, Public Works and Water Management, the Interprovincial Consultation (IPO), and the Water Boards, and since 2007 the Ministry of General Affairs (Onderzoeksbureau EIM, 2008). The steering group was responsible for the whole process of designing the programme, implementing it and reporting back to Parliament. An external programme office (AgentschapNL, former SenterNovem) supported and facilitated the implementation of the programme. For central activities such as education this programme office took the lead. For de-central activities such as the projects within pillar 3 (the "learning society") the provinces took the lead in cooperation with water boards and municipalities (LvDO, 2003). Per province various stakeholders were involved to create a Provincial Ambition Statement (PAS). The PAS had to fit the national level preconditions for LVDO and should be seen as a framework for provincial implementation. Co-financing was a prerequisite to ensure full involvement (LvDO, 2003). For the Province of Limburg the PAS was developed with input from the nature and environment education groups (NME), the Limburg Employers' Organisation, the collective organisation for independent entrepreneurs in the small and medium sized businesses in retail and trade, services and industry (LOZO), large industries, the Chamber of Commerce, the Water Board, the Drinking Water company (WML) (Interviews LvDO, 20082009). In the PAS for Limburg eight themes were identified and actors were invited to submit project proposals within those themes: mobility, technological top region, energy, water, nature, youth and other processes. Projects had to fulfil several sustainability criteria set by the Province. A cost-sharing of minimum $25 \%$ was requested (Province of Limburg, 2004). The programme management was shared between an internal manager from the Province and an external manager. These programme managers checked if the criteria were met, they helped projects, they took care of the process in general. Final decisions were made by the Provincial 
Executive, consisting of the Deputies and the Queen's Commissioner (Interviews LvDO, 2008-2009).

In essence LvDO 2004-2007 was a top-down, government steered approach and thus qualifies as a form of hierarchical governance.

In the following any reference to LvDO means only the programme in Limburg. Furthermore, this chapter focuses on the programme cycle 2004-2007 and on pillar 3: the learning society. How other provinces implemented the programme, or how implementation was realised in the other pillars is not investigated. The interviewees are project and programme managers at national and provincial level responsible for the Limburg programme and project leaders of Limburg projects.

\subsubsection{Greenport Venlo (GV)}

Greenports are agroclusters of national importance. Five Greenports have been set up since 2005, one of which is Venlo (Greenport Venlo, 2008). Venlo is a region in the North of the province of Limburg, situated around the city of Venlo. It is a distributional and logistical hub on the important trade routes between the Port of Rotterdam, Germany and Central and Eastern Europe. Furthermore, the region is important for horticulture, agricultural processing and applied agricultural and horticultural research (Termeer and Kranendonk, 2008).

Around 2001 a group of people concerned about the region's development established a regional dialogue with a goal to combine intellectual, political and financial powers and integrate regional and sector developments. They lobbied to ensure that the region became a Greenport (Termeer and Kranendonk, 2008). In 2006 GV officially started. The idea behind the Greenports was to recognise a region's importance for the international economic position of the Netherlands (Greenport Venlo, 2008). However, concrete goals or budget were not given by the national government. The name "Greenport" should be seen as a label for a region (Termeer and Kranendonk, 2008).

The designation of the Venlo region as a Greenport integrated both the regional movement towards development and innovation and the government's wish to emphasise the national importance of further development of the existing agroclusters. A group of public and private actors, researchers and facilitators joined forces in 2006 and prepared a regional development strategy for GV (Termeer and Kranendonk, 2008). According to the strategy, GV consists of an open innovation space that creates new transboundary connections. It has four interconnected pillars or themes: Creating value relates to the economic development which is the motor of GV. Innovative solutions to provide quality and smart connections across actors and sectors are essential. Learning to learn is about using and developing knowledge and skills. Quality of life is about sustainable regional development with a focus on creating an attractive living environment, cherishing it and further de- 
veloping it. The Basics are about creating the physical infrastructure for the other three pillars (Greenport Venlo, 2008; Transforum, 2008).

In order to realise this regional development strategy a network has emerged with representatives of government, research, business and education. It has been recognised in the GV mission and vision that contribution of these groups, and new connections between these groups, is essential for regional development. $A 5^{\text {th }}$ group, civil society, has been added more recently. The network includes continuously changing cooperations and alliances (Greenport Venlo, 2008). Steering is not done in a structured way. Within the four themes regular meetings are organised. GV is an unlimited network that can only partially be organised and structured (Greenport Venlo, 2008). However, the question of how to organise GV has been a recurring theme for discussion. The network has opted for minimum structures and maximum flexibility. Communities of Practice (CoP) are an important means for exchanging information. CoPs offer space and room for the exchange of knowledge and social networking (Termeer and Kranendonk, 2008). Because of the increase in activities over the years there was a need for more structure, which was found in part in the establishment of a Service point, that supports, inspires and catalyses the network. The Service point combines short to medium term concrete activities with long term strategic development (Interviews GV, 2008-2009). In order to deal with the diversity of the networks and activities, the Transforum project Streamlining Greenport Venlo was set up to organise a learning network with all stakeholders in a result oriented way to create regional sustainable development (Transforum, 2008).

\subsection{Methodology}

For this chapter 9 semi-structured interviews were conducted with eleven people. An interview guideline was used, but interviewees were given the freedom to deviate from the questions. This method was used to uncover issues that interviewees thought were important, but were not covered by the questions. Three of these interviews, with four people, concerned Greenport Venlo and the project Streamlining Greenport Venlo. The interviewees were process managers and project managers involved in facilitating processes and in reflecting on the process. The other six interviews involving seven people covered LvDO in Limburg over the period 2004-2007. These interviewees consisted of the national process manager for the region, the provincial process managers, and project leaders. All interviews were conducted in the period 2008-2009.

All of the interviewees had a working relationship with LvDO or Streamlining Greenport Venlo. A choice for process and project managers was made because they were actively involved in regional sustainable development processes and it was assumed they would be able to provide insights in problems and solutions they 
encountered in their work. (Table 5.1). The choice for these two case studies was made because of their different modes of governance. Beforehand, a clear idea on their perspective on sustainable development was not known. It was expected both used a well-being perspective.

Table 5.1: Characterisation of interviewees by role and type of organisation

\begin{tabular}{lllll}
\hline & Role & No. of people & No. of interviews & Type of organisation \\
\hline LvDO: & & & & \\
\hline & Programme management & 5 people & 4 interviews & Government, NGO \\
\cline { 2 - 5 } & Project leader & 2 people & 2 interviews & NGO, Government \\
\hline GV: & & & & \\
\hline & Core management group & 4 people & 3 interviews & Business, University \\
\hline
\end{tabular}

The nine interviews were set up with the theoretical framework of Chapter 2 in mind. The first cluster of questions dealt with background information. The next cluster contained questions about governance in the case study, to find out more about the mode of governance. The third cluster was about sustainable development in the case study to find out more about the perspective used. The last cluster was about problems and practices within the case study and about future developments to find out what "instruments" people used in the case study. The questions were structured in the same way for both case studies. However, because the nature of both cases was different, the exact phrasing of questions was slightly different. But, because the intention of the questions was the same for both case studies, the results are comparable. It should be noted that two of the LvDO interviews were conducted in English. See annexes $1 \mathrm{a}$ and $1 \mathrm{~b}$ and annex 2 of chapter 5 for the questionnaires.

The interviews were digitally recorded and later transcribed. Each transcript was then sent to the interviewee for corrections and final approval. Once the transcript was approved the files were uploaded in the text analysis programme MAXQDA 2007. A first round of classical coding occurred, in which a predetermined code based on the interview framework and on the theoretical framework of chapter 2 was used. The predefined codes were as follows, see box 5.1.

- Evaluation: text dealing with project/programme evaluation and monitoring

- $\quad$ Process: text dealing with how the project/programme was set up

- $\quad$ Stakeholders: text referring to the stakeholders involved

- background of the case study

- $\quad$ problems perceived by the interviewee in the case study

- Solutions to the problems used by the interviewee and proposed for the future

- Instruments used in the case studies

- Perspective on SD

- Mode of governance

Box 5.1: First round of coding: code system defined by interview framework 
A second round of free coding, based on grounded theory, was carried out. Grounded theory is concerned with the generation of theory from research, as opposed to research that tests existing theory. In such a case the researcher approaches the data with no pre-formed notions in mind, instead seeking to uncover patterns and contradictions through close examination of the data. It is a complex and a personal qualitative process (Lawrence Neuman, 2003; Veal, 2006). This second round of coding was initiated because there were too many text segments in the clusters of problems, solutions, and instruments to make a proper analysis. This round concentrated on the problems (129 text segments) and the solutions and instruments (together 219 text segments). Important to note is that solutions and instruments were renamed into "practices" and clustered together for this second round, as they were overlapping to a great extent. The free coding resulted in the following clusters, box 5.2:

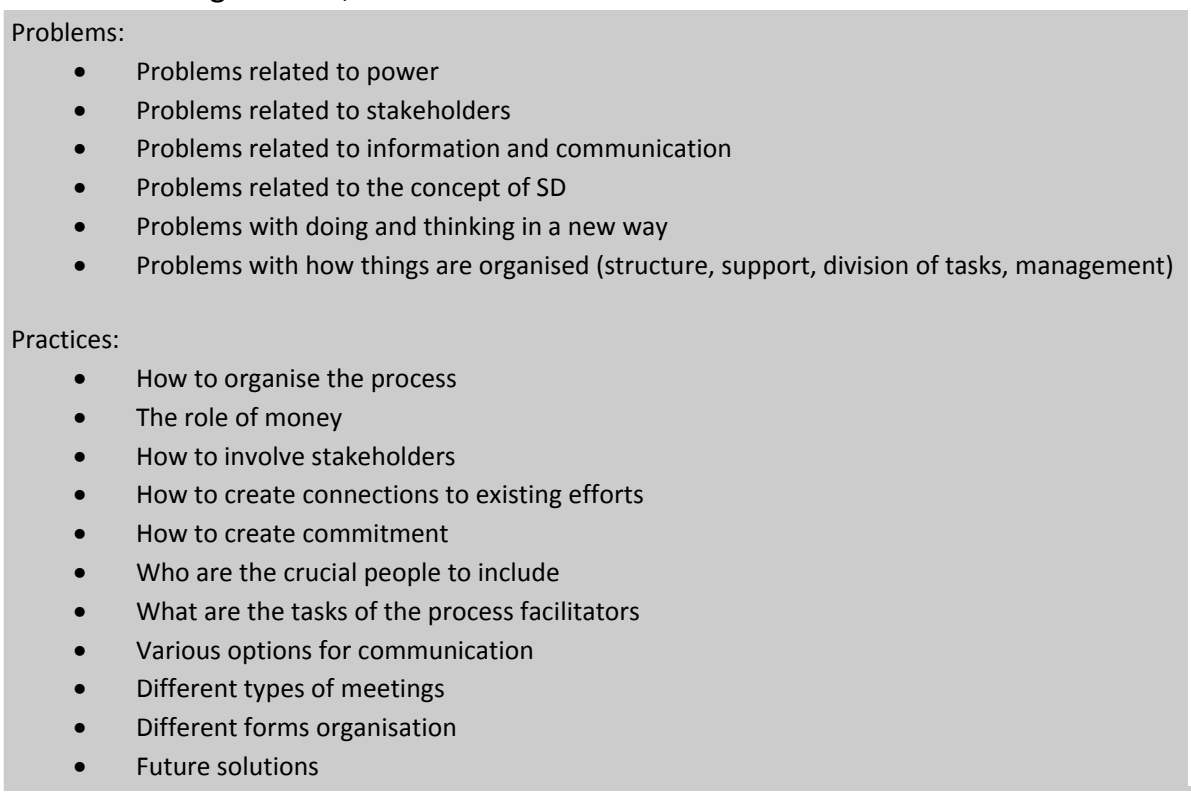

Box 5.2: Second round of coding of problems and practices based on grounded theory

In a third round of coding the clusters of problems and practices were grouped into larger themes. Three themes were seen to occur within the problems: problems related to the content of sustainable development, problems related to processes (organisational, informational) of LVDO and GV, and actor-related problems. Two themes were identified within the practices: process-related and actor-related practices (box 5.3). 


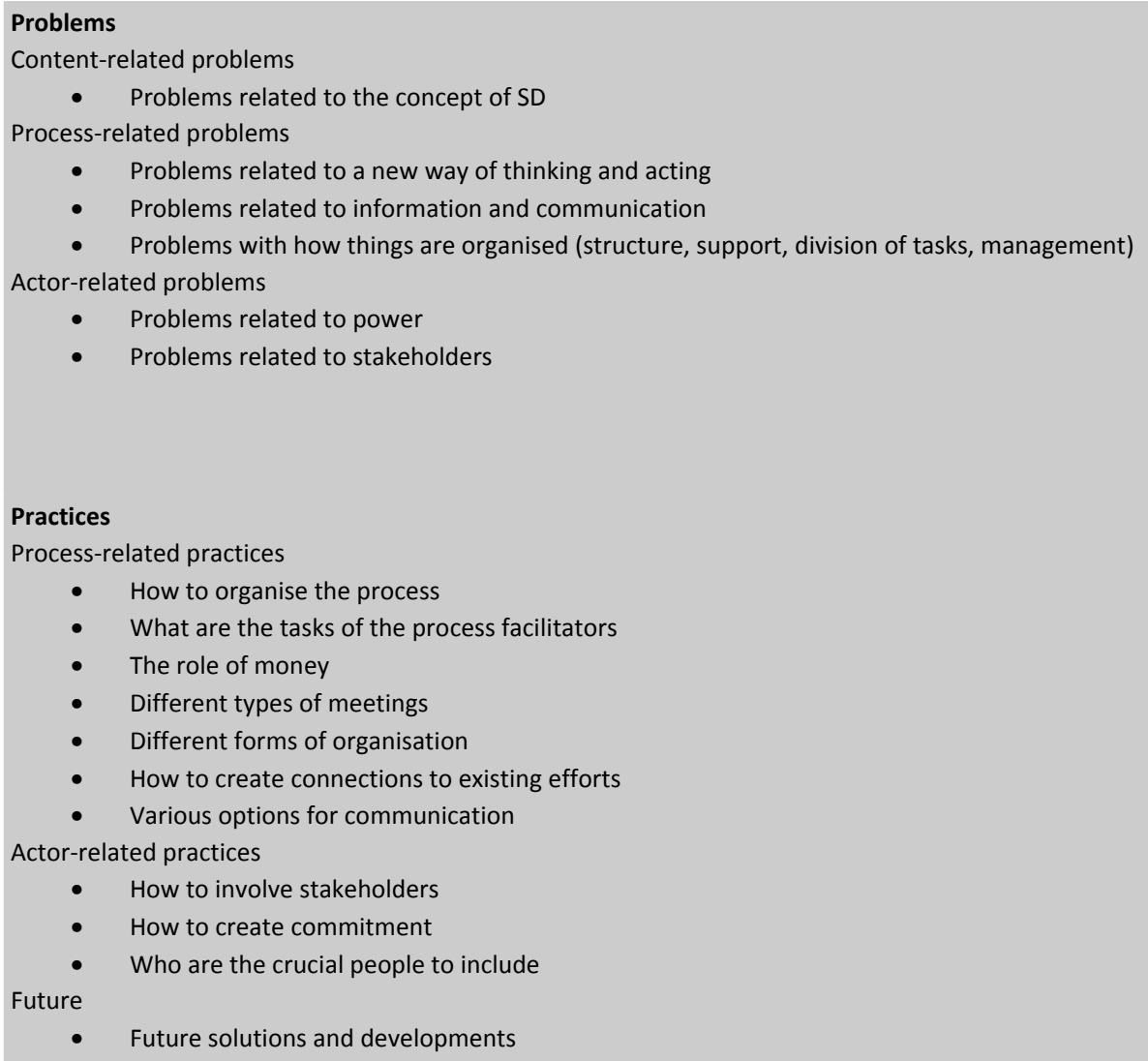

Box 5.3: Third round of coding grouping clusters of problems and practices into common themes

Each problem and practice is described in the following sections in the same format:

1. Description of problems and practices in the words of the interviewees (in grey boxes)

2. An assessment of similarities and differences of the particular type of problems and practices between GV and LvDO

3. An assessment of the relation of the particular type of problems/practices to sustainable development and governance. The characteristics of governance as mentioned in chapter 1 (actors, institutions, processes and instruments) are used to explore what type of governance problem we see.

\subsection{Problems encountered}

The interviewees were during the interview specifically asked about problems (annexes 1 and 2, chapter 5). But throughout the interviews they mentioned problematic issues. These text segments often included words such as "difficult", "too lit- 
tle", "but", "issue", "couldn't", "insufficient" and other words or phrases with negative connotations. It should be noted that some of the text segments were coded with more than one code because they did not only describe a problem related to, for instance, power, but also to communication and sustainable development.

The structure of the problems discussed is as follows:

Content-related problems:

- Problems related to the concept of sustainable development

Process-related problems:

- Problems with doing and thinking in a new way, as opposed to the old, unsustainable way

- Problems related to information and communication

- Problems with how things are organised (structure, support, division of tasks, management)

Actor-related problems:

- Problems related to power

- Problems related to stakeholders

\subsubsection{Analysis of problems that occurred in GV and LvDO}

\subsubsection{Content-related problems}

\section{Problems related to the concept of sustainable development}

The majority of the comments by interviewees on the concept of sustainable development were made in the interviews with LvDO participants, probably because sustainable development is not a goal as such, but rather one of the requirements for regional development in Greenport Venlo and has not yet been fully defined. LvDO is after all aimed at promoting sustainable development. An important issue was that the concept of sustainable development was not clear, and the jargon used was not clear. " $L v D O$ interviewee: Another issue is that in moving from $L v D$ to LvDO there has been a shift in concepts/jargon (social learning process; mainstream). A major problem was that at national level these concepts were not explained, and could be defined only after two years of experimenting in the field. This made it very difficult for the programme manager and regisseur to help the project leaders."

Interviewees said that sustainable development is seen too often as environmental protection and not as the full range of social development, economic prosperity, environmental protection, now and in the future, here and elsewhere. Related to the vagueness of the concept was the lack of including the notion of "impacts elsewhere" in projects. Also, the link of projects to sustainable development might not always have been clear for the larger public because of vagueness of the termi- 
nology. "LvDO interviewee: In one location people saw it became safer, that there was no more graffiti, and that people were not afraid anymore to go out at night. The question was whether people made the link with sustainability."

Furthermore, many stakeholders were not convinced about the benefits of becoming more sustainable and therefore, it was not seen as an urgent matter. "LvDOinterviewee: I felt like a Jehovah's witness because everybody wanted to close the door on me: "sustainable development, no, not for me"."

Getting a community feeling about sustainable development was not possible to achieve. Scaling up initiatives was difficult because the jargon was inaccessible, the people worked too much within their sectors and common approaches were difficult to distil. Inconsistency between requesting sustainability projects and not doing sustainability as a donor was also mentioned as a problem.

\section{Similarities and differences between GV and LVDO}

This field is almost exclusively dominated by the LvDO case. Probably because this programme deals explicitly with sustainable development, whereas for GV includes it as a pillar under development.

\section{Sustainable development or governance?}

These problems deal with the vagueness of the concept of sustainable development, focus on environment and lack of urgency. These are problems that are related to sustainable development, and probably to the lack of an overall vision. In general, sustainable development is perceived as the interrelatedness of people, planet and profit and includes time and place dimensions, meaning a well-being perspective. However, in implementation it is expressed as environment, thus more an ecological perspective. Another aspect of the problem is that it was difficult to convince stakeholders of the benefits, to create a common feeling (the feeling of working on the same topic), and also the communication of sustainable development was a problem. These problems are mostly related to the concept of sustainable development, rather than governance.

\subsubsection{Process-related problems}

\section{Problems related to a new way of thinking and acting}

The interviewees mentioned that implementing sustainable development requires a different approach. However, this new approach is not yet ready and a new way of thinking and doing things is not easy. Interviewees noted that for regional development in GV as well as in education on sustainable development (LVDO) the role of government and staff will have to become one of facilitation and requires different competences. Sustainable development should be discussed at the decisionmaking level, strategically and at the level of practitioners. Currently there is no 
mandate to start that. Social learning was not recognised in LvDO for its worth in sustainable development and regional development processes. "LvDO interviewee: two meetings were held between project leaders to discuss common problems. Even if the project themes aren't the same, the processes and problems are the same. But the province did not see the benefits of the approach because there was so little in common between projects. However, this social learning process was essential and project leaders evaluated the meetings positively and would have liked more meetings."

Traditional working structures such as a high level steering group with standard type meetings, or a large group dominated by government staff did not work. New ways of organisation and communication were sought. "GV-interviewee: But the problem we look at now is that the Service Point should become reality and now tasks and functions are being described that threaten to make it a traditional organisation again. Then the space for looking around in the network, listening and seeing opportunities will disappear."

In LvDO it was difficult to find a good way to "market" sustainable development. It was often mentioned that a tension was perceived between goal achievement and focus on processes in LvDO. "LvDO-interviewee: We see not always rationally acting people, their behaviour, and processes. These processes are difficult to steer, require a lot of time and commitment, and don't always have quantitative results. When setting up new programmes there should be more attention for steering of processes."

Also in obtaining loans for regional development and innovations (GV) the focus is very much on SMART goals which is difficult in innovation processes. "GVinterviewee: If you look at the processes in Greenport Venlo you are not held accountable for specific outputs, but is it important that things happens, that processes start up,.... You are dealing with the innovation climate. It should be sufficient to improve that but in practice you still need to be able to show what results you achieved, which is very hard when you have a catalyst role."

Resistance among some stakeholders to work on sustainable development was noted by the interviewees. "LvDO-interviewee: It is true, change takes extra time in the beginning. But change can only happen because you will do something extra, and after that life becomes quieter again. But that phase of doing extra things is a barrier for schools, businessmen, etc."

Another important issue that was mentioned often was the need to connect people, sectors, scale levels, knowledge and initiatives. It was mentioned that it was difficult to connect people, issues, etc, and this lack of connectedness was seen as hampering progress towards sustainable development. Government at all levels is seen as an important player in LvDO to facilitate connections. LvDO-Interviewee: "Connecting parties and projects was to me an important task of the province." and "Local governments should be involved, but they aren't. They often have pro- 
grammes in the field of sustainable development and they have an important task in communicating sustainable development to the citizens."

\section{Similarities and differences between GV and LVDO}

The problems occurred in both case studies. The only problem that was exclusively mentioned in LVDO was the reluctance or even resistance to doing things in a new way or thinking in a new way. Probably the reason for this can be found in the different nature of the two case studies. GV is a voluntary network in which people willingly cooperate. The problems mentioned in LvDO occurred among provincial staff who were expected to participate in making their organisation more sustainable.

\section{Sustainable development or governance?}

This set of problems relates to the tension between existing structures and a need for structures that allow social learning, innovation, connecting people, scale levels, sectors, knowledge and initiatives. This relates to the governance dimensions of processes and actors. Whereas actors in the existing structures prefer goals, the new way of working focuses on processes. Officials will have a new role as facilitators rather than enforcers or regulators. This is a governance issue and the problems are problems resulting from hierarchical governance or from a transition towards deliberative governance.

\section{Problems related to information and communication}

Interviewees said that sustainable development is a difficult concept that remains abstract. "LvDO-interviewee: The province should think better about how to communicate sustainability better (as concept or as framework): either leave out the term sustainability completely and identify what should be done, or shape sustainable development in an integrated way and properly name it." The diverse topics that fall within sustainable development were difficult to group and to communicate in a coherent way so that people felt they belonged to a common thing. "LvDO-interviewee: It as difficult to create a common feeling for sustainable development. It was either nature \& environment, or SME, or sugar beets, or industrial zones. Everybody had their own topic. There is not really a field of expertise "learning for sustainable development" in which people are interested." Also, people belonged to different sectors and it was difficult to show them what common ground they were covering. Furthermore, in GV, it was difficult to inform people about what was happening and to create a central contact point because of the diversity in activities. Reporting to donors and stakeholders about a process such as Greenport was also difficult because it was not easy to describe what exactly was happening. This unclarity was also an issue for stakeholders who did not understand what was happening and who was involved. Lastly, it was noted that if the 
goals are vague, or not clearly named and communicated, people are reluctant to participate. "GV-Interviewee: Something we see is that many initiatives about different things emerged over the past years which leads to a certain tiredness of people to go to meetings. And it leads to confusion because so many knowledge initiatives have been initiated by so many parties that no-one knows what belongs to what."

\section{Similarities and differences between GV and $L V D O$}

Although both case studies experience problems in this field, GV mentions it more often. A great number of initiatives, unclear expectations, and communicating what is happening are their problems. The LvDO problems are related mainly to complexity of the topic, connecting projects and difficulty in reaching certain stakeholders because of vague goals.

\section{Sustainable development or governance?}

This is a set of problems that deals with the interaction between groups of people. It relates to the actor dimension of governance. More formal structures are sought, as well as informal communication and information exchange, in both case studies. Also, these problems deal with the abstract concept of sustainable development which is difficult to communicate in a coherent way to different groups

\section{Problems with how things are organised (structure, support, division of tasks, management)}

The complexity of the topic, as well as the complexity of the organisation caused problems in the case studies. Stakeholders were reluctant to participate because they did not have an overview of what was happening or because there was too much bureaucracy, and reporting was difficult. Process managers were frustrated because they could not do everything, there was a lot to do with too little money, and organising a network was not easy. Supporting the various processes in such a complex matter poses problems as well. It was impossible for one person to do all that was necessary. A variety of skills and expertise was needed. Interviewees said that if that is not possible, support and facilitation can only be partially successful. "LvDO-interviewee: in order to carry out the LVDO programme properly, there has to be a key person from every sector (economic, social, ecological sector, global level) involved in management of LvDO. This would make the programme more effective because you can assess project ideas from different sides and you can direct them as well. However, there was not enough money to realise this structure." When concepts or jargon changed, it was difficult for facilitators to explain it to the participants. They said they needed to attract the right expertise as there was only a limited number of experts in the region. Sometimes it was difficult to show the benefits of a more sustainable approach because the facilitator was no 
expert in that specific field. In one case, the facilitator had problems to help the process because he said he was not a teacher but a government employee. It was observed that government employees will have to take on new roles as facilitators in sustainability processes and thus specific skills are needed. "GV-interviewee: Government has a very decisive role, but also has to take care to get companies interested and to guide them. A new role emerges in such a network for government and its employees. I think a pro-active attitude is necessary, and staff that actively builds out networks en identify themes. But you need a different type of government staff for that." Lack of time to organise everything with a limited number of facilitators, lack of time to build trust among members of the network and lack of money to develop complex processes was often mentioned. Lack of time was also mentioned as an important reason for stakeholders not to participate. Lastly, the possibility for steering the processes was problematic. "GV-interviewee: development of the network as such is a barrier: the phases, the roles, the tasks, accountability, and the question for SMART objectives. We have most conflicts with financial donors about accountability because that does not match with an innovation culture." On the side of stakeholders more structure and guidance was requested in order to benefit from more connectedness of people and efforts. On the side of the facilitators the steering was not easy due to lack of power, or complex structures, or deliberative steering approaches.

\section{Similarities and differences between GV and LVDO}

Specifically for the LVDO programme we see problems related to goals that were too ambitious, marginality of the programme that caused lack of interest, and monitoring that was too complex and did not supply many lessons. Specific for Greenport Venlo is the need for structure. The network grew organically and did not follow traditional organisational structures. Now, the lack of structure makes it difficult for potential stakeholders to become part of the network and it is also difficult to explain what is happening within the network without a clearer structure

Support or facilitation is an issue in both case studies although it is expressed in LvDO as having too small a team with not enough of the necessary skills and knowledge to fulfil the obligations and in GV as observations on roles of different stakeholders and the need for enough expertise in the network. Lack of time is only mentioned in LVDO. This might be due to the limited time of the programme cycle of four years. Lack of money is mentioned by both case studies. Division of tasks is also mentioned by both, as well as steering. With the LvDO the tendency is to increase steering and control on the contents of the projects. Within GV there is a tension between creating a more transparent structure and clearer division of tasks and at the same time keeping the structure of the network open to allow for innovations. 


\section{Sustainable development or governance?}

The lack of structure, the need for structure, complexity of roles, tasks, and expertise are mainly governance related problems that lie in the dimension of processes and institutions. There is a tension between providing space for deliberative processes (deliberative governance) and providing structure (hierarchical governance), which seems to boil down to transparency and focus. Furthermore, the concept of sustainable development created problems because it was hard to show benefits coming from a more sustainable way of working.

\subsubsection{Actor-related problems}

\section{Problems related to power}

Several interviewees, mainly from LvDO mentioned that not having power to steer was not easy. Some saw this as a reason for not being able to implement sustainable development, some concluded that they needed to act in other ways (facilitate) to bring about change. "LvDO-interviewee: We are working at the systems level, but we don't have any power; we can only facilitate." "LvDO-interviewee: content-wise I thought it was great and very important, but I was not in the position to get anything done." Another issue was found at the higher levels of decisionmaking (e.g. Deputy, Queen's commissioner, Aldermen). It was noted that if there is not enough attention at that level for the programme, the efforts will fail. " $L v D O$ interviewee: An important point for consideration is getting enough attention at the level of decision-makers. We work at all levels at the same time. There are many staff members, sometimes complete departments, with a personal drive, but to get commitment at the highest levels to agree to an ambition to work on sustainable development is very difficult. Our possibilities to deal with that are very limited." Projects were hampered by high-level individual involvement and confusion of roles. 


\section{Similarities and differences between GV and LVDO}

These problems are mainly related to the case study LvDO. The reason for this could be that in LVDO power is divided over the scale levels. The programme is developed at the highest level, and cannot be changed by the lower levels.

\section{Sustainable development or governance?}

These problems are related to governance. Power has to do with relations between actors and how processes are designed. The power related problems deal on the one hand with the structure in LvDO in which the implementers lack power to make decisions or to enforce things. On the other hand it deals with the political power that hinders the programme. These are issues of hierarchical governance.

\section{Problems related to stakeholders}

A common problem in the case studies was that some stakeholders were difficult to reach. This translated into specific groups that were difficult to reach (citizens and CSOs in Greenport Venlo). "GV-interviewee: But it is difficult to find the right organisations and pressure groups. We see that especially civil society organisations have difficulty to change, whereas sustainable development requires systems change." Also there was no interest of stakeholders to participate which was shown by difficulties to get project proposals in LVDO, it was difficult to get trade associations involved, and no municipalities were involved in setting up the programme. "LvDO-interviewee: A bottleneck was that not many retail associations reacted to our call for proposals. On one hand it is understandable, on the other hand it is a way to bring your shopping center to the attention of shoppers, with coaching for free and the possibility of a reward. We thought it was an attractive package, but apparently it wasn't." Another issue was that commitment was lacking for sustainable development, especially at the highest political levels. "LvDOinterviewee: Another problem was that decision-makers said "well, it is very complex and there is little money involved, so it is of little interest to us"." Not so much a problem, but more an observation made is that success depended on a group of enthusiasts. Without such a group there is not much that can be done.

\section{Similarities and differences between GV and LVDO}

These problems occur both in GV and in LvDO but the nature of the problems is different. GV struggles with getting the civil society stakeholders to participate, whereas market, government, research and education are participating voluntarily. LvDO has problems with commitment (stakeholders are reluctant to participate) and interest (stakeholders are not interested). 


\section{Sustainable development or governance?}

This set of problems is about the actor dimension of governance. It deals with how to get stakeholders to participate, how to reach them, how to get commitment and enthusiasm. In both case studies it is felt that stakeholders cannot be forced, but need to participate voluntarily. These are mainly deliberative governance problems. Furthermore, the fact that commitment for sustainable development is lacking at the highest levels is both a governance and a sustainable development problem. Apparently the urgency for, or the ownership of, or the ability to deal with sustainable development is not present.

\subsubsection{Lessons derived from the problem analysis}

In conclusion, we can say that the majority of problems seems to be related to governance issues (institutions, actors processes and instruments). Content-wise, the problem seems to be not so much whether the perspective on sustainable development is ecological or well-being, but that the goal is vague, and benefits are unclear, thus making it very difficult to communicate with people. This is in line with the results of chapter 4 (survey results).

Process-wise, we saw problems in the realm of connect scale levels, sectors, people, knowledge and initiatives. Furthermore, creating structure, getting an overview of what was happening and a tension between goal focus and process focus. Information and communication towards stakeholders and among stakeholders posed a problem, a fear to change was mentioned and difficulties in creating trust and connecting people. We saw a tension between existing and new structures, a government that should facilitate and a network that needs to get more structure. Furthermore we see that many problems relate to actors. There were power problems, it was difficult to reach certain stakeholders, and interest or commitment was lacking.

We see also some differences and similarities between the case studies. Both cases have a similar approach to sustainable development: well being in theory, but implemented as environment, which is again similar to what comes out of our survey results (chap 4) and policy analysis (chap 3). The power problems are created because of hierarchical governance in LVDO in which some have more power than others. A solution to stakeholder problems seem to lie in the realm of deliberative governance. Stakeholders cannot be forced to participate, but must be coerced. Confirming this, we see in GV more commitment and enthusiasm due to the voluntary nature of the network. The organisational problems and information and communication problems do not seem to be the exclusive domain of LvDO or GV, although GV reports more often on the difficulty in communicating all that is happening within the organically growing network. The problems with new ways of thinking and acting describes a deliberative way of doing things that comes into 
conflict with current, more hierarchical structures. We see this both in LvDO and GV.

\subsection{Current practices}

Interviewees were asked in the interview guideline which "instruments" they use for their day to day work with sustainable development. Because the term instruments was somewhat confusing, they were asked how they solved problems and how they achieved successes.

These text segments often consisted of descriptions of what was done. A special cluster consists of thoughts on what should or could be done in the future. It should be noted that some of the text segments were coded with more than one code because they did not only describe a practice related to, for instance, how to involve stakeholders, but also how to create commitment or what the tasks are of a process facilitator.

The analysis is structured along the following lines:

Process-related practices:

- How to organise the process

- What are the tasks of the process facilitators

- The role of money

- Different types of meetings

- Different forms of organisation

- How to create connections to existing efforts

- Various options for communication

Actor-related practices:

- How to involve stakeholders

- How to create commitment

- Who are the crucial people to include

Future:

- What future solutions and developments are foreseen

Each of the groups will be described below. A description contains the viewpoints of the interviewees, followed by an overview of differences and similarities of practices for the case studies LvDO and GV. Finally, the practices are analysed from the angle of the perspective on sustainable development and the mode of governance. 


\subsubsection{Analysis of practices in GV and LvDO}

\subsubsection{Process-related practices}

\section{How to organise the process}

Interviewees mentioned that it is important to keep an open process, and to be aware of traditional patterns. "GV-interviewee: We chose for network steering, but if you haven't done that before it is easy to relapse to traditional steering patterns". A project document could help in this by indicating what important topics are to be included, and what current trends are, but not by describing fixed targets. "GVinterviewee: it (GV) has become a movement with a certain direction. It has never been boarded up with budgets, deliverables and milestones. That gives space to start up new initiatives and new themes." Process facilitators were part of the process. The starting point for action should always be the whole picture, not its individual parts. "GV-interviewee: I find it typical that we often do other things than our assignment says. And still it is accepted. That is because you operate from an overall picture as a group and you use that too in projects."

\section{Similarities and differences between GV and LVDO}

These practices have only been mentioned by GV. A reason might be that in GV the process has been very open and therefore a lot of attention has been given towards organising the network. The LvDO was organised along traditional lines and the process was to a certain extent fixed.

\section{Sustainable development or governance?}

Organising the process is a typical governance issue. Among the practices mentioned an open process with emphasis on the process instead of goals is mentioned in GV. This relates more to a deliberative type of governance. In LvDO the organisation of the process was more hierarchical.

\section{What are the tasks of the process facilitators}

All interviewees had, at various scale levels, the task of managing the process. This
ranged from regional project level of projects within LvDO, to network processes in
Greenport Venlo and national management of LvDO. Therefore, a lot of tasks of
process facilitator were mentioned in the interviews. A process facilitator moti-
vates others within the process, connects, lobbies, provides advice, creates trust,
inspires, challenges, provides overview, supports partners within the process,
thinks along, facilitates, reflects on past experiences and progress, ensures the
communication towards the outside, ensures internal communication, consoli-
dates.


"LvDO-interviewee: For sustainable development you need to take a very open attitude that allows you to critically reflect on the way you yourself do things."

"GV-interviewee: The central issue is the power of connecting parties and if you don't do that, things go wrong."

The facilitators did this by keeping an open attitude towards how you can deal with sustainable development. They visited projects and had telephone contacts. They organised an extra project in LVDO to see how a more diverse involvement (more sectors/disciplines) could be realised. Sometimes they had the function of helpdesk for projects. They organised meeting among project leaders, with various stakeholders. They organised a multi-stakeholder group. They brought people together based on their function as decision-makers or related to certain themes.

"LvDO-interviewee: Our main activity in the beginning was to give advice to the projects. During the implementation we worked as help-desk for projects that faced problems. Furthermore, we were intermediaries between projects and researchers, media, other interested parties. Another task, together with the province was to advise on how the programme could be changed. Another important task was to connect the different projects."

"GV-interviewee: Now, we can only do certain things because we have the trust of people. Trust is very important for innovation."

"LvDO-interviewee: We gave people an entrance that they didn't have before. You see that they don't know what the nature organisations can do for them. They didn't have the simple bridges we had to offer, those points of entry."

The process facilitators identified gaps in knowledge and ensured that training was given. They monitored progress and learning and reflected on it. They organised workshops, Communities of Practice, and thematic meetings. They helped to formulate questions for further action. They created structure.

"GV-interviewee: You should support staff and train them. GV requires new skills."

"LvDO-interviewee: We look at the needs for training, identify knowledge gaps, and sometimes commission a specific training or development of a training. "

\section{Similarities and differences between GV and LVDO}

In details there are some differences, but in general the tasks of process facilitators are very similar. 
Sustainable development or governance?

Process facilitators are dealing with all dimension of governance: they work with the actors, they connect to institutions, they are aware of the instruments, and they understand ongoing processes. Most practices mentioned in both case studies reflect a deliberative way of acting, where stakeholder relations are mostly horizontal, although the LvDO's facilitators at provincial and national level are the leaders of the programme.

\section{The role of money}

In LvDO subsidies were an instrument to help sustainable development. A method of co-financing was custom, probably to ensure ownership and responsibility. "LvDO-interviewee: important for project management is that we had the system of co-financing. Projects would only receive funding if they provided their own funding alongside the province ". GV interviewees mentioned that innovative processes that require loans or funding, also require a change in the existing structures of banks, donors and legal departments. "GV-interviewee: We try to change the old preconditions. If you want innovation you should make sure innovation is embedded and that means the preconditions of donors, banks and legal departments should change. This means some things must change within these organisations too."

\section{Similarities and differences between GV and LVDO}

Monetary practices were mentioned more often by LvDO then GV, which is not strange because LvDO is a subsidy programme and thus subsidies are used as an instrument to promote sustainability. GV mentions it more as an instrument they are using, not providing, although they try to change the requirements attached to donor money, and loans to allow for innovative processes.

\section{Sustainable development or governance?}

Money, or subsidies, is an instrument for governance purposes. Besides subsidies, also existing structures of banks and donors for loans are mentioned.

\section{Different types of meetings}

In both case studies meetings were held for different purposes and in different forms. Regarding the purpose of the meeting, it was mentioned that meetings were held to share information, to get new players involved, to get decision-makers involved, to create a vision, to make a SWOT, to reflect on past experiences, to bring the process back on track and think of better ways to do that. " $G V$ interviewee: We have sessions on reflection and then we can show people which role they have had. But you need to wait for the question to arise within the network. At this moment people want to know "what did we do these past years" and now we could bring in things like social learning." The form of meetings that were 
mentioned were knowledge circles or tables, regular standard type meetings, a regional dialogue in the form of a an atelier with creative sessions, project team meetings, workshops, network meetings, working sessions of several days, focus group meetings, away-day (heisessie).

\section{Similarities and differences between $G V$ and $L V D O$}

What is a difference between the two case studies is the greater diversity of types of meetings in GV. LvDO has a limited range of meetings, and is at the management level mainly working with traditional type meetings (a group around a table). At the project implementation level, different types of meetings such as knowledge circles and a multi-stakeholder group were organised. GV uses more participatory instruments.

\section{Sustainable development or governance?}

Meetings are a practice related to actors and processes. The purpose of a meeting can be more hierarchical such as bringing the process back on track, or more deliberative such as creating a vision. But to identify if a meeting is used as a hierarchical or deliberative instrument it is also important to look at its form. A visioning meeting with a very clear guidance and steering is a sign of hierarchical governance, while a visioning meeting with a diverse group of actors and process facilitators, convened by a few enthusiasts, is a sign of deliberative governance.

\section{Different forms of organisation}

In the interviews different forms of organisation were mentioned. Often, many different types of organisation could be found together. A steering group of decision-makers was mentioned, sometimes assisted by a working group of policy staff. A multi stakeholder group with a common goal was mentioned, as well as Communities of Practice (CoPs) grouped around a common goal. "LvDO-interviewee: The Multi Stakeholder approach was seen as very promising and valuable. We took a long time over issues as creating the group which is not easy and takes time, and you need to motivate people and get hold of their common goals." A variety of groups exists in GV. Groups can be formed by of similar people (farmers, agroinnovators), or around similar themes (C2C, logistics), or with similar functions (strategy development). "GV-interviewee: There are many groups, also from within the Service Point. An interesting thing is that because there is intensive cooperation by broad groups of people who formerly didn't work together, people now call each other when there are new developments." Projects were an organisation form in LVDO and in GV. GV had a service point that included people of participating organisations. A (project)team was mentioned as an important way to achieve defined goals. A board was established. There were networks within the network. A 
core group existed in GV to think about the way forward. It is thought that virtual communities could be an option.

\section{Similarities and differences between GV and LVDO}

Similar to the different types of meetings, GV has a greater variety in organisational forms than LvDO. LvDO works with traditional organisation schemes of working groups, steering groups and projects. GV has projects too, as well as CoPs a core group, a service point, virtual communities.

\section{Sustainable development or governance?}

The form or organisation relates to institutions and processes. Some types of organisation are more hierarchical (steering group, project), whereas a CoP, or a thematic group, or a network is more deliberative. However, we see that mix-forms occur in both case studies.

\section{How to create connections to existing efforts}

One of the GV-interviewees said "you cannot throw away existing systems, you need to work with them". Connecting to these existing systems was done in several ways. The province used a twinning concept in which sustainable development initiatives were linked to mainstream programmes. "LvDO-interviewee: We chose projects related to mainstream projects and themes; Mainstream means issues that come up frequently in the local newspapers or processes that influence Limburg's future. ... We tried to involve people from the province working on a mainstream issue with the LVDO projects. Sometimes that worked, depending on the project, and theme." Thus, the LVDO became part of the larger system and that helped the programme.

Furthermore, the support from a trade association was helpful in clarifying benefits to the members. Not only progressing towards more innovation, but also connecting horizontally to existing initiatives is done in GV to create a relation between the current situation and the desired situation. Linking concepts such as Cradle to Cradle and quality of life to regional economic development was a strong point in GV, as one of the interviewees states. "GV-interviewee: I think that the strength of GV is that we managed to link several concepts to regional economic development, such as quality of life and Cradle to Cradle. People see those things as linked.... The ambition in the region that the Floriade (international horticultural show) should be $\mathrm{C} 2 \mathrm{C}$ also puts people in a certain mindset that otherwise would not have happened." In any case, connecting to existing activities is important. It was said that project managers have to offer concrete actions and results. Embedding activities in your own network and linking them to other networks is a factor for success. 


\section{Similarities and differences between GV and LVDO}

Both case studies describe practices to improve the connection to existing efforts. LVDO mentions the twinning of projects with provincial programmes, the linking of LvDO to the coalition programme, reaching out towards a sector through its trade association. GV recognises the importance to link the network to existing efforts and does this by linking QoL and C2C to traditional regional development, by using their own networks, by trying to develop understanding among banks, legal departments and donors.

\section{Sustainable development or governance?}

This relates to the governance dimensions of institutions and processes. Without linking to existing institutions and processes, a new system cannot work. The province makes projects follow the mainstream of the provincial priorities. This is a slightly more hierarchical approach. GV links vertically and horizontally without following clear steering structures and with horizontal stakeholder relations, which means a more deliberative approach.

\section{Various options for communication}

A variety of practices for communication can be seen in both case studies. Communication of progress was done by means of external evaluators, mid-term evaluation, yearly project reports and audit reports. People were asked about their experiences in a questionnaire. Information was disseminated in a brochure, newsletters, essays. In one of the projects shopping centres demonstrated new technology such as LED Christmas lights and explained about it to get clients interested. The TV programme "koplopers" is another communication activity. A physical location for a network, where it can meet, and where people can get information is currently being built in Venlo in the shape of the InnovaTower. A spontaneous action was the establishment of a Greenport House that serves a similar purpose. Furthermore, a Service Point was established in the heart of the network. Within this Service point there is a group of people working on realising short term projects to show concrete results, whereas another group is working on more strategic long term issues. Really important in making the network's activities more tangible was the production of a vision book. This book served as an anchor or focus for all activities. Lastly, interviewees said a website is important and other visual materials such as business cards, flags, pens, press releases, etc.

\section{Similarities and differences between GV and LvDO}

Communication practices in GV focus more on making the network more tangible and visible. A reason for focusing on this might be the open network structure without a clear division of roles. For the network itself, for new actors to join the network and for other interested parties, it became important to have some tangi- 
ble contact points. The provincial LvDO belongs to the provincial structure, has a contact point and a brochure. The clarity of structure was probably a reason why creating tangibility was not an issue in LvDO.

The practices in LvDO focus partly on the formal information requirements related to the subsidy programme, and partly on providing information on the ongoing efforts.

\section{Sustainable development or governance?}

Communication relates to the governance dimension of actors (how actors interact,) and to the dimension of instruments (communication as an instrument to bring about change) The traditional communication ways such as evaluation reports, audits, progress reports, are signs of hierarchical governance. Communication practices such as newsletters, a TV programme, essays, a place to meet, are more signs of horizontal stakeholder relations and deliberative processes. Communication also relates to sustainable development, because that is the theme about which is communicated.

\subsubsection{Actor-related practices}

\section{How to involve stakeholders}

In both case studies there are examples of how the, sometimes problematic, issue of involving stakeholders was conducted. One solution was the organisation of a project to identify the stakeholders and check out what their interests were. "LvDO-interviewee: in the mid-term evaluation it was noted that there were too few economic and social projects. In order to better involve and connect the sectors it was advised to have a new project 'Bruggen Bouwen' (building bridges). The project brought together 5 people from different sectors each with a broad societal support. The project was good because the actors checked in each sector what was happening with regards to sustainable development. This turned out to be much more than expected." Also, multi-stakeholder groups were organised to create mutual trust, learning and involvement. Getting into contact with existing networks, such as associations of entrepreneurs was done. A municipality was involved in one project which was important for success. Sometimes connection was sought with educational institutions or science to solve some issues. Getting expertise and knowledge into the process was another way. Being aware of the different groups of stakeholders is important. GV had defined 5 groups to be involved and was actively looking for involvement of civil society ("omgeving") that was not present. Interviewees said that getting the story to be alive among the peers and colleagues of the various participants is important too. "GV-interviewee: All those people who were part of the core group feel themselves ambassadors and hold 
presentations in their networks." Therefore, you need people who know the region, who are committed.

\section{Similarities and differences between GV and LVDO}

Both case studies mention practices that are geared towards involving stakeholders. LvDO mentions how they found stakeholders. GV mentions also how they found stakeholders, for instance in linking with science, but also describes some the factors that are important for involvement such as pride in the region, making the story alive with the participants' peers.

\section{Sustainable development or governance?}

This relates again to a governance dimensions: the dimension of actors. No indication of hierarchical or deliberative governance can be found.

\section{How to create commitment}

The case studies conducted concrete actions to create commitment such as a breakfast meeting devoted to sustainability for the Deputies, or the Floriade event, an energy scan, or a price for shopping centres which helped to create interest, enthusiasm and commitment. "GV-interviewee: At a meeting for the Floriade all of a sudden we saw local and cultural organisations who wanted to think along and to see what they could do and what the Floriade could mean for them. There is commitment." Political commitment which is expressed in policy documents and budgets was mentioned as a tool to generate broader commitment. Giving a good example, e.g. as provincial administration, helps to create trust and commitment. It was also said that informing members of a trade association, or other interested parties of what is happening and what the consequences are for them if they continue unsustainable behaviour was important. A multi stakeholder group helped in one project to create mutual trust and opened people's perspectives. But even so participants needed constant reminders of the benefits to be expected. " $L v D O$ interviewee: Benefit is not necessarily financial benefit. It can also be immaterial, such as company image." Good examples are needed to inspire people. It was experienced that enthusiastic groups or people generate more enthusiasm. The vision document in GV helped to create commitment. People have pride in this vision document. Pride in the region is important too, noted interviewees.

\section{Similarities and differences between GV and LVDO}

Practices related to creating commitment are dominated by LvDO. Concrete examples in the form of a prize, an energy scan, a high-level breakfast have been given. A form to do this is a multi stakeholder group, or a behavioural code. Factors that are important are making clear what the benefits are and giving a good example. 
In GV the practices were creating a vision together, or having a meeting around a new regional activity such as the Floriade. Factors for getting commitment are pride in the region, interest in the development of the region, having good examples and concrete actions.

\section{Sustainable development or governance?}

Creating commitment relates to governance processes and governance actors. Many different practices have been described. Policy documents and budget are more government related and by nature more hierarchical practices. Trust, events, encouragement, a common vision, can exist equally in a more hierarchical or a more deliberative approach. Showing the benefits is another practice with which commitment is created.

\section{Who are the crucial people to include}

Crucial people that are named in both case studies are high level enthusiasts who give the idea a face such as decision-makers who are figure heads able to realise support within their networks, or change agents. People in normal organisations with a drive to realise sustainable development are important too and they were helped. Entrepreneurs were used as sustainability Ambassadors. Enthusiastic people within GV took on the role of Ambassador without prompting. They gave presentations among their acquaintances. "LvDO-interviewee: If someone at a very high level is committed, think of Obama, then you can change things. Especially in the field of sustainable development you need people like that."

\section{Similarities and differences between GV and LVDO}

Both case studies speak about ambassadors, high level politicians and change agents.

\section{Sustainable development or governance?}

This relates to the governance dimension of actors. Both decision-makers as well as other figure heads in society are important. Enthusiastic people at all levels are needed.

\subsubsection{Future}

\section{Future solutions and developments}

Most interviewees gave throughout the interview indications about how certain problems could be solved, or how processes could be improved. These are practices that were not yet applied in the case studies. In LvDO it was mentioned that a different approach to requesting project proposals will be used, indicating specific topics for proposals. Furthermore, regular stakeholder meetings will be held and 
subject groups/sustainability circles will be formed to implement the provincial ambition statement, with different questions as the programme moves along. Programme management will not be out-sourced as it was in 2004-2007 to ensure more internal commitment. Also more attention will be given to the provincial administration's sustainability. It is thought that knowledge management should get more attention, i.e. make the knowledge accessible for large groups of people. Reporting back to projects about evaluation results and progress reports should be done more frequently. Project results should not be the prime focus, but doing things in a different way. High-level people should become ambassadors. Between the development of a new programme and the finishing of the old one there should be enough time to reflect on lessons learnt. There should be a team of experts supporting the programme managers. "LvDO-interviewee: It would be easier to have a programme just focusing on e.g. sustainable energy, and have a programme manager who is an expert on that. In the case of LVDO we would need a team of advisors from different sectors or themes of LvDO." Also, there should be stronger responsibility within the province for the programme. The programme should be clarified more. It needs support and political commitment. Stakeholders from different sectors should be involved to advise the programme. Aspects of impacts of our actions elsewhere should be taken into account at the project planning phase. The province should work more on connecting parties, both formally and informally. They should make the overall picture visible. New projects and programmes should focus more on process approaches than on concrete goals. Sustainability should be communicated in a much clearer way by the province. Creating more knowledge might not be the way. Maybe using the existing knowledge should get more attention. The highest possible should become the norm as in the Japanese top-runner model.

In GV the following possible practices were mentioned. A clearer structure will be developed. Government should make sure that entrepreneurs take part and help them with that. A pro-active attitude from government is necessary. Patience is needed and space should be given to the development of new ideas, because that takes time. All themes with GV should be addressed from the perspectives of the 5 Os to generate a wide input of knowledge and expertise. There should be more capacity, e.g. at the service point to help initiatives along. Participants in the network should get support and need training in group processes. Maybe a new division of tasks is needed. More young high educated people are needed in the region. GV wants to give more attention to the combination of tacit knowledge and codified or explicit knowledge. "GV-interviewee: A vision of the future should be developed for a longer time horizon that allows space for many different individual visions. Maybe behavioural rules or basic agreements about quality of life and sustainable development could be developed within the network (similar as an Indian tribe in Mexico has done regarding fair trade coffee) that do not describe goals, but 
describe the way to act. In that way you will get deeper norms and values than in a vision. It has to do with quality of life." A fan club could be developed, the "friends of GV". GV should get a place in the InnovaTower. A core team should look the overarching developments and be able to make them visible. They should be able to recognise issues and challenges and to help the process along. They should also be aware of what could happen in the next 20 years and what possible steps can be taken now. A future perspective for all stakeholders should be made, civil society needs to be more involved, the pillars of GV should be further developed, and new ways of communication are needed.

\section{Similarities and differences between GV and $L V D O$}

Clearly, there are different emphases in the two case studies on what practices they would like to implement.

In LvDO the focus is on management of the programme, knowledge management, dealing with interdisciplinarity, creating political commitment, dealing with reflection, clarifying sustainable development, and focusing on processes instead of goals.

In GV important issues are consolidating the network structure, dealing with the tension between innovations and existing structures, working from a broad integrated view, providing training, creating a long term vision/behavioural code, improving communication.

\section{Sustainable development or governance?}

The future solutions relate to all four governance dimensions, actors, institutions, processes and instruments.

\subsubsection{Lessons derived from the practices analysis}

First of all, it is clear that most practices relate to governance. They relate to the process, actors, institutions or instruments, or a combination thereof to achieve sustainable development. This does not mean that sustainable development is less important than governance, but it shows once again that governance and sustainable development are interrelated but also separate. Sustainable development requires vision and clarity about the direction. But achieving sustainable development is a complex governance issue.

Process-related practices are related to hierarchical governance as well as deliberative governance in a mix. It was noted that there is a greater diversity in deliberative practices in the GV case, and in LvDO there is more preference for hierarchical structures. This is reflected in the different types of meetings and the variety of organisational forms which is greater in GV and leans more towards participation than in LVDO. But in both case studies we see a mix of hierarchical and deliberative approaches, as well as a search for the best approach. Apparently there is a need 
for both openness and structure, innovation and connection to existing structures. Money is mentioned by both case studies as a instrument, although in a different way. In GV it is a means to facilitate certain processes, and in LvDO it is an instrument for steering sustainable development. For both case studies communication of ongoing activities is important. For GV it is also an important tool for creating more tangibility (website, address, business cards) and for LvDO as a reporting tool towards contractual reporting requirements (reports to donors).

Actor-related practices show us in both case studies the importance of the process facilitators. They have many different tasks and need skills and knowledge to carry out their tasks. They also need to know the networks they are operating in.

Both case studies recognise the need for engaging ambassadors or change agents as crucial people for the move towards sustainable development.

Big differences between the two case studies lie in the areas of creating commitment and organising the process. Creating commitment seems to be of major concern to LVDO. Organising the process and questions of structure are the domain of GV. This is reflected, too, in the description of problems. Commitment and structure were indicated in the problems-section as problems. The practices in this section clearly aimed to solve them.

\subsection{Conclusion}

In section 5.1 the questions of this case study research were mentioned as:

- What problems occurred in Greenport Venlo (GV) and Learning for sustainable development (LvDO)?

- What practices, i.e. solutions to problems, actions, did practitioners use to implement sustainable development?

- What are the differences and similarities between GV and LVDO regarding problems and practices?

- What lessons can we draw regarding the mode of governance and the perspective on sustainable development and the problems and practices observed in the two cases?

This chapter leads us to insights on barriers to implementation of sustainable development from the perspective of practitioners. To summarise some of the most important problems observed in the two case studies of GV and LVDO, we saw that there is a need for a vision, goals and clear benefits of sustainable development. Furthermore, actors cannot always be reached, or they are not committed to or interested in sustainable development. Important skills of process managers are not always present in government institutions. Tension exists between new deliberative approaches and hierarchical structures. The problem is how to provide 
structure and maintain innovation space at the same time. In LvDO we see this tension reflected in a fear, or resistance, to change in the provincial administration.

Not surprisingly, many practices focused on stakeholders. In both case studies we observed that stakeholders are of great importance. If they do not take part, not much will happen. However, these stakeholders cannot be forced to participate in a subsidy programme or in a regional development network. They should be persuaded and invited. For that purpose, process facilitators with proper skills are important. They should be able to motivate stakeholders, mediate when necessary, make connections, facilitate difficult processes, provide information, reflect on the process, etc. This is a confirmation of what we found in the literature review about new roles of government and special personal skills needed. A mix of approaches (hierarchical and deliberative) is used and many different types of meetings and organisations are used.

Regarding similarities and differences of the two case studies we can state that the sustainable development perspective used in both case studies is one of well-being, which seems to be implemented in practice in the sphere of environment. This is not different from the findings in various other chapters. Furthermore, GV knows a more deliberative form of governance, while LvDO has a more hierarchical mode. In both case studies we see a mix of approaches that have deliberative and hierarchical elements. The search in GV is for more structure, but, at the same time, to maintain openness for innovation. GV has benefited from the process resulting in the vision document. In LvDO structural issues were rare, because the structure was straightforward. Instead, commitment issues and getting stakeholders interested were more prominent.

What lessons can we learn from these results? The focus placed on governance in these two case studies is an expression of the wickedness of sustainable development. If sustainable development were simpler, we would have less governance issues enveloping it. Clarifying the sustainable development vision, goals and benefits will not eliminate all governance issues, but will help to focus on the really important things: finding new forms of governance for moving towards sustainable development. As is shown in GV, a vision document can make a process more tangible and can generate pride in the process. Clear elements of these new forms of governance are skilled facilitators for guiding and helping stakeholders; coupling new efforts to existing policy, projects and concepts; focusing on the roles of stakeholders and on processes instead of on structures/institutions.

Furthermore, a mix of governance approaches would be appropriate while the "old" institutions should not be forgotten. At the same time it is clear that traditional governance structures are not suitable for sustainable development. 
From the previous chapter we know that people would like to know about the benefits of sustainable development. They will be more easily committed when the benefits are clear. This could be a lesson for LvDO: to clarify what benefits participants in the subsidy programme will have. At this moment the benefits for government (at various levels) is clear: more people who know about sustainable development will help to move towards sustainable development. However, what do citizens gain?

Furthermore, it seems clear that a transparent structure helps people to focus on contents. GV has recognised the need for structure, but does not want structure to impair innovation capacities. They see that communication and improved tangibility can help. In the literature a different approach was taken: a clear identification of roles was propagated when many different actors take part. This approach could help GV to get out of the current impasse on organising the network. Instead of defining structure, the roles of actors could be defined. So, instead of creating a structure with a Service Point, responsible for project and strategy design, one could identify the role of project designers, or strategy designers. People who want to take part in this role, can take part, which makes it opener for other actors to participate. A Service Point seems rather closed, something that provides service. By naming the different roles it becomes clearer which tasks are being done. In the same line of thought, it could be useful to describe processes (e.g. reflection, decision-making, generation of ideas) and develop groups around those processes. Of course, a similar approach is already practiced: working with CoPs is a noninstitutionalised thematic approach.

Sustainable development is about living, working, and acting in a different way. If we wish to steer such a process, we are dealing with a wicked issue for which there is no blueprint solution. This implies a new role for government in creating an enabling environment where implementation can take place. 


\section{ANNEX 5.1a: interview guideline Leren voor duurzame ontwikkeling (Dutch) \\ Interview Guide Sturing op duurzame ontwikkeling Leren voor Duurzame Ontwikkeling \\ [plaats/datum]}

\section{Interviewer:}

\section{Annemarie van Zeijl-Rozema}

Promovendus bij International Centre for Integrated assessment and Sustainable Development (ICIS), Maastricht University, the Netherlands

Project: Sturing op duurzame ontwikkeling: de provincie Limburg

\section{Geïnterviewde:}

[naam]

[instituut]

\section{A: Inleiding:}

- Het project 'Sturing op duurzame ontwikkeling: de provincie Limburg' is een onderzoeksproject dat wordt uitgevoerd door ICIS en deel wordt gefinancierd door de provincie Limburg. Het loopt van 2005-2009. Het doel van het project is om beter te begrijpen hoe de kloof tussen duurzaamheidsbeleid en praktijk gedicht kan worden. Ik kijk onder meer naar de gebruikte visie op DO, hoe je kunt communiceren over DO, op welke manier gestuurd wordt, welke andere sturingsmanieren en -instrumenten er zijn, en hoe je vooruitgang kunt meten. De link tussen wetenschap en praktijk is erg belangrijk. Zo heeft het wetenschappelijke werk over het meten van DO inmiddels geleid tot het uitbrengen van de Limburgmonitor 2007.

Ik heb twee case studies uitgekozen: Leren voor DO en Greenport Venlo, een vanuit overheidssturing en de ander vanuit gezamenlijke netwerksturing. In dit interview wil ik graag LVDO aan de orde stellen. Ik zal enkele algemene vragen stellen, vervolgens ga ik in op welke betrokkenen er zijn, de bijdrage van het programma aan DO en de uitvoering van het programma.

- Als u dit wilt zal het interview anoniem verwerkt worden

- Na het interview wordt u een samenvatting toegestuurd waar u commentaar op kunt geven

- Heeft u bezwaar tegen opname van het interview?

\section{B: Persoonlijke Informatie:}

1. Wat is uw functie binnen [instituut]?

2. Is [instituut] markt, overheid, maatschappelijke organisatie?

3. Hoe is [instituut] betrokken geraakt bij LVDO?

4. Hoe lang bent u zelf al betrokken bij LVDO? 


\section{C: Algemene informatie over LVDO (m.n. over stakeholders):}

5. In het opzetten van het programma, uitwerking en evaluatie zijn diverse partijen betrokken. Dat zijn o.a. de rijksoverheid, SenterNovem, provincies, waterschappen, projecteigenaars.

- Zijn er nog andere stakeholders, welke?

6. Er zijn in LVDO allerlei fases te onderscheiden, zoals

- Bedenken van het gehele programma (nationaal nivo)

- Maken van een PAS (provincie nivo)

- Besluit van welke projecten gefinancierd worden

- Uitvoering van het programma

- Evaluatie van de projecten

$\circ$ Andere fases?

- Bij welke fases is [instituut] betrokken? Op welke wijze?

7. Met betrekking tot sturing:

○ Welke stakeholders zijn betrokken bij besluitvorming? Welke besluiten?

- Welke rol heeft [instituut] bij besluitvorming? Welke besluiten?

- Heeft [instituut] de vrijheid om de eigen projecten vorm te geven?

○ Heeft [instituut] de vrijheid om de eigen projecten uit te voeren?

- Heeft [instituut] iets gemerkt van sturing vanuit bijvoorbeeld de provincie en IVN? Hoe?

8. Aan welke projecten nam [instituut] deel? Wat was de rol van [instituut] in de projecten (coördinator, enige partij, deelnemer,...)?

\section{D: Bijdrage LvDO aan duurzame ontwikkeling}

9. Wat is volgens u de duurzaamheidsdoelstelling van het LvDO?

10. Draagt het programma volgens $u$ bij aan DO? Op welke wijze? Is er blijvende invloed?

11. Hoe dragen de projecten van [instituut] bij aan DO?

\section{E: uitvoering van het programma}

12. Hoe zorgt [instituut] dat de projecten een succes zijn?

13. Op welke manier voerde [instituut] de projecten uit? Speciale werkvormen?

14. Waren er problemen in de uitvoering van de projecten? Zo ja, welke en hoe werden ze opgelost?

15. [Is [instituut]/Zijn de projecten] van [instituut] geëvalueerd in de eindevaluatie? Wat was het resultaat? 


\section{Afsluitende opmerkingen}

Heeft u nog verdere opmerkingen, vragen of aanvullingen?

Zijn er nog andere stakeholders waar we mee moeten praten? 
ANNEX 5.1b: interview guideline Leren voor duurzame ontwikkeling (English ${ }^{14}$ )

Interview Guide Governance for Sustainable Development

[date/place]

\section{Interviewers:}

Annemarie van Zeijl-Rozema

$\mathrm{PhD}$ researcher at International Centre for Integrated assessment and Sustainable Development (ICIS), Maastricht University, the Netherlands

Project: Governance for Sustainable Development: The case of Limburg, the Netherlands

\section{Anna Boenisch}

Bachelor Student University College Maastricht

\section{Interviewee:}

[name], [organisation]

\section{A: Introductory Remarks:}

- We undertake research contributing to the overarching question of how sustainable development can successfully be implemented. Since (policy) instruments are a means for governance, we look at what types of policy instruments exist that can spur the implementation of sustainable development, and where such instruments are missing / need to be developed.

- Your anonymity will be preserved if you wish so and the responses and information you provide during the interview will be treated with confidentiality.

- After the interview a summary report will be prepared and sent to the respondent via e-mail or post for review and additional comments

- With permission of the respondent the interview will be recorded with a digital voice recorder. Recording the interview will facilitate the quality and validity of response records and the summary report.

\section{B: Personal Information:}

1: What is your position in [organisation]?

2: How is [organisation] involved in LvDO?

3: How long have you been involved with LvDO?

\section{C: General Information on LvDO and PAS:}

\footnotetext{
${ }^{14}$ Two of the interviews were conducted in English
} 
4: Involved in making up the programme carrying it out and evaluating are the central government, the province, water boards, and project holders. Are there any other stakeholders involved, if so which?

5: Which stakeholders are involved in what stages?

Designing the overall programme (nation-wide)

Designing PAS (Ambition Statement for Limburg)

Decision on Funding of Projects

Implementing programme in Limburg

Evaluation of Projects

6: With regards to the mode of governance,

Which stakeholders are involved in decision-making?

Does [organisation] have a role in decision-making?

What freedom does [organisation] have in the implementation of the programme?

7: What is the future of the programme? Will it be continued?

8: Is [organisation] in the context of the LvDO programme to be considered civil society, market or government?

\section{D: The Programme's contribution to Sustainable Development}

9: What is the sustainability goal of the programme?

10: In your view, does the programme contribute to sustainable development? In what ways? Will there be a lasting influence?

\section{E: Projects}

11: Which projects have been carried out between 2004 and 2007?

12: What support did [organisation] give with regard to projects and how was this support given?

13: Did problems occur during the implementation process? If so, what problems, and how were they solved?

14: According to PAS, the plan was to have a project started or at least extensively planned in each of the 8 areas by 2005. Did this happen? If not, why not?

\section{F: Evaluation}

15: As far as we know, an evaluation of LvDO has been carried out, can you provide us with information with regards to the results of that evaluation?

16: What was the role of the [organisation] in the evaluation?

17: How were the projects evaluated (criteria and results)?

18: How was the contribution towards sustainable development evaluated (criteria and results)?

19: What will be done with the evaluation? 


\section{Concluding remarks:}

Do you have any final remarks or questions with regard to this topic, this interview or this research project?

Can you recommend any other important stakeholders (for instance project holders) who might be able to shed more light on these issues? 


\title{
ANNEX 5.2: Interview guideline Greenport Venlo
}

\author{
Interview Guide Sturing op duurzame ontwikkeling \\ Greenport Venlo \\ [Plaats/datum]
}

\section{Interviewer:}

\section{Annemarie van Zeijl-Rozema}

Promovendus bij International Centre for Integrated assessment and Sustainable Development (ICIS), Maastricht University

Project: Sturing op duurzame ontwikkeling: de provincie Limburg

\section{Geïnterviewde:}

[naam]

[instituut]

\section{A: Inleiding:}

- Het project 'Sturing op duurzame ontwikkeling: de provincie Limburg' is een onderzoeksproject dat wordt uitgevoerd door ICIS en deel wordt gefinancierd door de provincie Limburg. Het loopt van 2005-2009. Het doel van het project is om beter te begrijpen hoe de kloof tussen duurzaamheidsbeleid en praktijk gedicht kan worden. Ik kijk onder meer naar de gebruikte visie op DO, hoe je kunt communiceren over DO, op welke manier gestuurd wordt, welke andere sturingsmanieren en -instrumenten er zijn, en hoe je vooruitgang kunt meten. De link tussen wetenschap en praktijk is erg belangrijk. Zo heeft het wetenschappelijke werk over het meten van DO inmiddels geleid tot het uitbrengen van de Limburgmonitor 2007.

- Ik heb twee case studies uitgekozen: Leren voor DO en Greenport Venlo, een vanuit overheidssturing en de ander vanuit gezamenlijke netwerksturing. In dit interview wil ik graag Greenport Venlo aan de orde stellen. Ik zal enkele algemene vragen stellen, vervolgens ga ik in op welke betrokkenen er zijn, de bijdrage van het programma aan DO en de uitvoering van het programma.

- Als u dit wilt zal het interview anoniem verwerkt worden

- Na het interview wordt u een samenvatting toegestuurd waar u commentaar op kunt geven

- Heeft u bezwaar tegen opname van het interview?

\section{B: Achtergrond Informatie:}

1. Wat is uw functie binnen [instituut]?

2. Wat is voor u Greenport Venlo? (omschrijving, pijlers, belangrijkste activiteiten, stakeholders) 
3. Wat is voor u Streamlining Greenport Venlo (SGV)? (omschrijving, pijlers, belangrijkste activiteiten, stakeholders)

4. Bent $\mathrm{u}$ betrokken bij GV of bij SGV of beide?

5. Hoe is [instituut]/bent uzelf betrokken geraakt bij Greenport Venlo/Streamlining Greenport Venlo?

6. Hoe lang bent $\mathrm{u}$ al betrokken bij Greenport Venlo/SGV?

7. Wat is de rol van [instituut]/uzelf bij Greenport Venlo/SGV? (projecten? Algemeen? Monitoring?)

8. Wie is uw opdrachtgever mbt Greenport Venlo/SGV?

C: Algemene informatie over Greenport Venlo (m.n. over sturing en stakeholders):

9. De 5 Os zijn belangrijk: Overheid, onderwijs, ondernemers, onderzoek en omgeving. Zijn deze allemaal betrokken bij Greenport Venlo/SGV? Bij welke $O$ hoort [instituut]?

10. Is er een management of andere structuur in greenport Venlo/SGV? Rol [instituut]? Wie zijn er verder bij betrokken?

11. Welke netwerken zijn er? Rol [instituut]?

12. Hoe kom je in 1 van de bestaande groepen (netwerken, CoP, kerngroep)?

13. Kun je bepaalde taken onderscheiden in de netwerken?

14. Wie neemt beslissingen? En wat is rol [instituut]? Bijv.:
a. Bepalen missie
b. Visiedocument
c. Bepalen thema's/pijlers
d. Andere belangrijke zaken?

15. Met betrekking tot sturing:

a. welke stakeholders zijn betroken bij besluitvorming? Welke besluiten?

b. Welke rol heeft [instituut] bij besluitvorming? Welke besluiten?

\section{D: Bijdrage Greenport Venlo/SGV aan duurzame ontwikkeling}

16. Zijn er specifieke groepen die zich met DO bezig houden?

17. Wat is de duurzaamheidsdoelstelling van Greenport Venlo (of van de specifieke projecten/ groepen genoemd onder 18)?

18. Welke defintie van DO hanteert u daarbij?

19. Dragen de activiteiten van Greenport Venlo/SGV/project X/groep Y volgens u bij aan DO? Op welke wijze? Is er blijvende invloed?

\section{E: uitvoering van activiteiten m.b.t. greenport Venlo/SGV}

20. Welke activiteiten binnen GV/SGV waren/zijn sucesvol. Waarom? Had [instituut] daar een rol in? 
21. Welke problemen zag/zie je bij activiteiten binnen GV/SGV. Hoe werden ze opgelost?

22. Wat is de toekomst van Greenport Venlo/SGV?. Wat zijn de belangrijkste veranderingen die gaan komen of die zouden moeten komen?

\section{Afsluitende opmerkingen}

Heeft u nog verdere opmerkingen, vragen of aanvullingen? 



\section{An adaptive indicator framework for monitoring regional sustainable development}

Based on Zeijl-Rozema van, A., Martens, P., 2010. An adaptive indicator framework for monitoring regional sustainable development: a case study of the INSURE project in Limburg, The Netherlands. Sustainability: Science, Practice and Policy 6: 6-17.

\subsection{Introduction}

Because the results of sustainable development efforts often only become visible after a long period of time, it is necessary to monitor the implementation of processes as they unfold. Continuous appraisal helps to make progress visible and to steer processes in the appropriate direction. However, a meaningful assessment of sustainable development encounters problems regarding the choice of indicators and the integration and interpretation of information. In general, indicators by themselves tell us little about how well a system is doing in relation to the goal of sustainability, or how it will respond to certain policy initiatives. There is a vast range of published criteria for measuring and evaluating sustainable development, but most of them are geared to the global or national level (Bühler-Natour and Herzog, 1999; Graymore et al., 2008). At the national level, indicator sets include the framework of the United Nations Commission for Sustainable Development (UNCSD) and the European Union (EU) sustainable development indicator framework (EU, 2005c; UN, 2007). Sustainability indicators have been developed for a variety of purposes, such as policy reform, socioeconomic assessment of rural areas, benchmarking, justification of public expenditures, support for land stewardship, and intergenerational equity (King et al., 2000). They have been applied at different geographic scales, such as countries, regions, and cities (Graymore et al., 2008). However, several authors state that measuring sustainable development at the national level, or with national-level data, might fail to capture critical issues at the regional level (Bühler-Natour and Herzog, 1999; Herrera-Ulloa et al., 2003; Reed et al., 2006). Graymore et al. (2008) show that various methods reported to be useful at different levels of spatial detail - including the regional - are not completely effective at the regional scale due to data limitations and a top-down definition of sustainable development. This chapter investigates how regional sustainable development can be monitored in an integrated way, and what barriers occur.

Pointing out that values may differ across regions, Stevenson \& Ball (1998) propose an approach to measuring the sustainability of materials that allows for this vari- 
ability instead of applying generic standards. McManus (2008) contends that a regional unit of analysis incorporates processes that go beyond the regional level. For example, in the case of the Upper Hunter region of Australia, the coal-mining, horse, and wine industries all affect regional sustainability, but are also part of national and global processes. Regional assessments should incorporate such considerations, recognizing that "regional sustainable development is a relative concept and is a process of becoming" (McManus, 2008). A danger of selecting indicators without taking into account the context or a common vision is that they may not provide useful insights about sustainability.

Numerous methods for identifying indicators exist, as well as a variety of criteria for selecting indicators. Indicators are often identified by means of participatory processes (e.g. Bell and Morse, 2004; Mickwitz and Melanen, 2009), and this process is often combined with a literature review of available indicator sets (BühlerNatour and Herzog, 1999; Kelly and Moles, 2002; Putzhuber and Hasenauer, ; Wallis, 2006). It is also common for researchers themselves to select the relevant indicators (Bouman et al., 1999; Herrera-Ulloa et al., 2003; Viglizzo et al., 2003). Criteria used to decide on indicators include objectivity and ease of use (Reed et al., 2006), the Bellagio Principles ${ }^{15}$ (Ramos and Caeiro, 2009), availability of time series, and inclusion in official government-formulated sustainable development indicator (SDI) lists (Herrera-Ulloa et al., 2003). Further criteria are simplicity, scope, quantification, sensitivity, and timeliness (Kelly and Moles, 2002). Spangenberg (2002) suggests that indicators should show the status of a domain, as well as interlinkages among domains. Another aspect of indicators is the weight factor that is assigned to them. Again, a multitude of approaches exists. Some authors consider all indicators of equal importance in their sustainability reports (EU, 2005c; Eurostat, 2007; IISD and JRC, 2009; Provincie Limburg (Belgie), 2006), while other researchers use participatory processes for ranking the indicators to identify the most important ones for a given region (Kelly and Moles, 2002; Mickwitz and Melanen, 2009). It is also common to use regression analysis (Putzhuber and Hasenauer), to seek out weakly correlated indicators (Herrera-Ulloa et al., 2003) or to rely on coefficient-generating tools and models (Bouman et al., 1999).

In summary, there are different ways to identify indicators, to determine selection criteria, and to assess relative importance. Moreover, measuring sustainable development is not only an objective issue, but, unavoidably, a normative and thereby a political one. Taking into account the diverse meanings of sustainable development and its specific interpretations in various regions, it is often difficult

\footnotetext{
${ }^{15}$ The Bellagio principles serve as guidelines for the entire assessment process including the choice and design of indicators, their interpretation, and the communication of results. They are interrelated and should be applied as a complete set and are intended to start and improve assessment activities of community groups, nongovernmental organizations, corporations, national governments, and international institutions. See http://www.iisd.org/measure/principles/progress/bellagio_full.asp
} 
to identify indicators for carrying out sustainability assessments. Indeed, Reed et al. (2006) observe that indicator selection is just one step in a sequence that starts with identification of the context and constituent visions and strategies.

This chapter discusses an adaptive indicator framework for measuring regional sustainable development. It is adaptive in the sense that it allows for the inclusion of regional characteristics and different methods for selecting indicators. This socalled INSURE ${ }^{16}$ method, developed to find meaningful indicators at the regional level, was implemented in four case-study regions: Antalya (Turkey), Limburg (The Netherlands), Lombardy (Italy) and Pardubice (Czech Republic). Instead of just measuring the "symptoms of unsustainability" through individual sustainable development indicators, INSURE sought to get to the "causes" with a more fundamental understanding of the region as a system. During the project it became increasingly apparent that indicators become more meaningful with this approach. The real challenge is not to identify indicators, but to look for the optimal way to combine them to provide a picture of regional sustainable development (cf. Grosskurth and Rotmans, 2005; Wiek and Binder, 2005). The flexible framework inherent in INSURE puts the indicators into perspective with the aim of coming to a regional assessment. This chapter discusses the challenges we faced (some of which remain unresolved) and the different roles and actors involved in carrying out this task.

The next section discusses the normative aspects of measuring sustainable development and the roles of policy-makers and scientists in the steps of the monitoring process. Especially defining the perspective on sustainable development is a normative issue. The role of indicator frameworks as an expression of the political view on sustainable development is then discussed. The importance of indicator frameworks and the roles of policy and science are further explored in the sustainability assessment of the Limburg region in The Netherlands. Based on the outcomes, several challenges for monitoring are discussed and conclusions are drawn that give some insight into assessing sustainable development at the regional level.

\subsection{Measuring sustainable development: a normative issue}

The search for effective sustainability indicators continues to be framed primarily as a technical or scientific problem rather than a political challenge. Although science clearly is needed to develop understanding of the underlying systems, states, and processes that indicators reflect, the role of scientists in selecting policyrelevant indicators is less clear. McCool \& Stankey (2004) observe that the actors involved in identifying indicators are making choices at the interface of science and

\footnotetext{
${ }^{16}$ Details on INSURE (Flexible Framework for Indicators for Sustainability in Regions, Using System Dynamics Modelling) are at http://www.icis.unimaas.nl/projects/insure). The research program was active between 2004 and 2007.
} 
policy. These authors also note that indicators are often selected based on our ability to measure a particular phenomenon (a technical issue) instead of on the need to measure it (a normative issue).

The field of sustainability science generally recognizes that scientists and policy makers are part of a heterogeneous network that has to manage different kinds of knowledge (cf. IHDP, 2008; Martens, 2006; Regeer et al., 2009; Reitan, 2005). The different styles of knowledge creation in these domains must be integrated to bridge the gaps among science, policy, and practice. With respect to indicators, we also encounter a need for knowledge integration. The social and normative question "what is to be sustained" should always precede the search for indicators (Zeijl-Rozema van et al., 2008). Without societal agreement on this point, it is impossible to identify relevant and valid indicators.

McCool \& Stankey (2004) and Reed et al. (2006) contend that establishing sustainability goals should be the starting point for measuring sustainable development. However, when scientists intervene on what should be sustained, they move into the realm of decision making. As scientists are usually not elected through democratic processes, they should be extremely cautious about setting sustainability goals and standards. Sustainability should ideally be determined by what the community values within the broad framework of the triple bottom line (people, planet, profit) or the Brundtland definition (Reed et al., 2006; Stevenson and Ball, 1998; Wallis, 2006). Tools to assess progress must be developed within the context of the local circumstances (Wallis, 2006). Sustainable development is not a single, well-defined concept; rather, various positions and perspectives exist. Whichever view is propagated, it entails a normative choice (Zeijl-Rozema van et al., 2008). After establishing sustainability goals, the next step in the process of measuring sustainable development is the selection of appropriate indicators. If the goals are clear, experts can typically find indicators that show progress toward them. However, if the goals are ambiguous, the selection of indicators will reflect the selectors' worldview and emphasize certain areas while neglecting others, regardless of policy priorities.

The last step is the interpretation of results. Here, again, much depends on the setting of goals, as well as on the criteria. Without criteria it becomes extremely difficult to judge whether a development is sustainable or unsustainable. A distinction is therefore evident between the roles of science, on the one hand, and policy and society, on the other hand. A linkage between the two is required and the question becomes how to realize it.

Reed et al. (2006) distinguish four steps for developing and applying sustainability indicators. The corresponding linkages to science and policy, as we see it, are mentioned in brackets:

1. Determine the context; identify the key stakeholders and define the system or area relevant to the problem being studied [science/policy]. 
2. Establish sustainability goals and strategies [policy].

3. Identify, evaluate, and select indicators (where evaluation refers not to interpretation of the data, but rather to assessment of the representativeness of the indicators) [science].

4. Collect the data to monitor progress [science/policy].

McCool \& Stankey (2004) indicate that interaction and participation of actors from science and society - and thus coproduction of knowledge - are essential for regional assessments of sustainable development. They observe that scientists have important roles to play, such as clarified problem framing, system description, system measurement, display of outcomes, and interpretation of implications and options. The public and policy makers are responsible for providing clear sustainability goals to support and enforce monitoring, to evaluate monitoring data, and to implement policies leading to sustainability. In their words, "the respective roles are interdependent, essential, and mutually informing, and the processes used in implementing indicator information are iterative, adaptive, and ongoing, incorporating new information as society learns how to better measure and monitor important system information." (McCool and Stankey, 2004).

If we combine the two frameworks, the relationships depicted in Figure 6.1 emerge. In this illustration, the dark grey signifies the role of policy and the light grey the role of science. The rectangles, connected by arrows, denote the steps in the process of assessing sustainable development. For each step, the roles of actors from policy and science are indicated. 


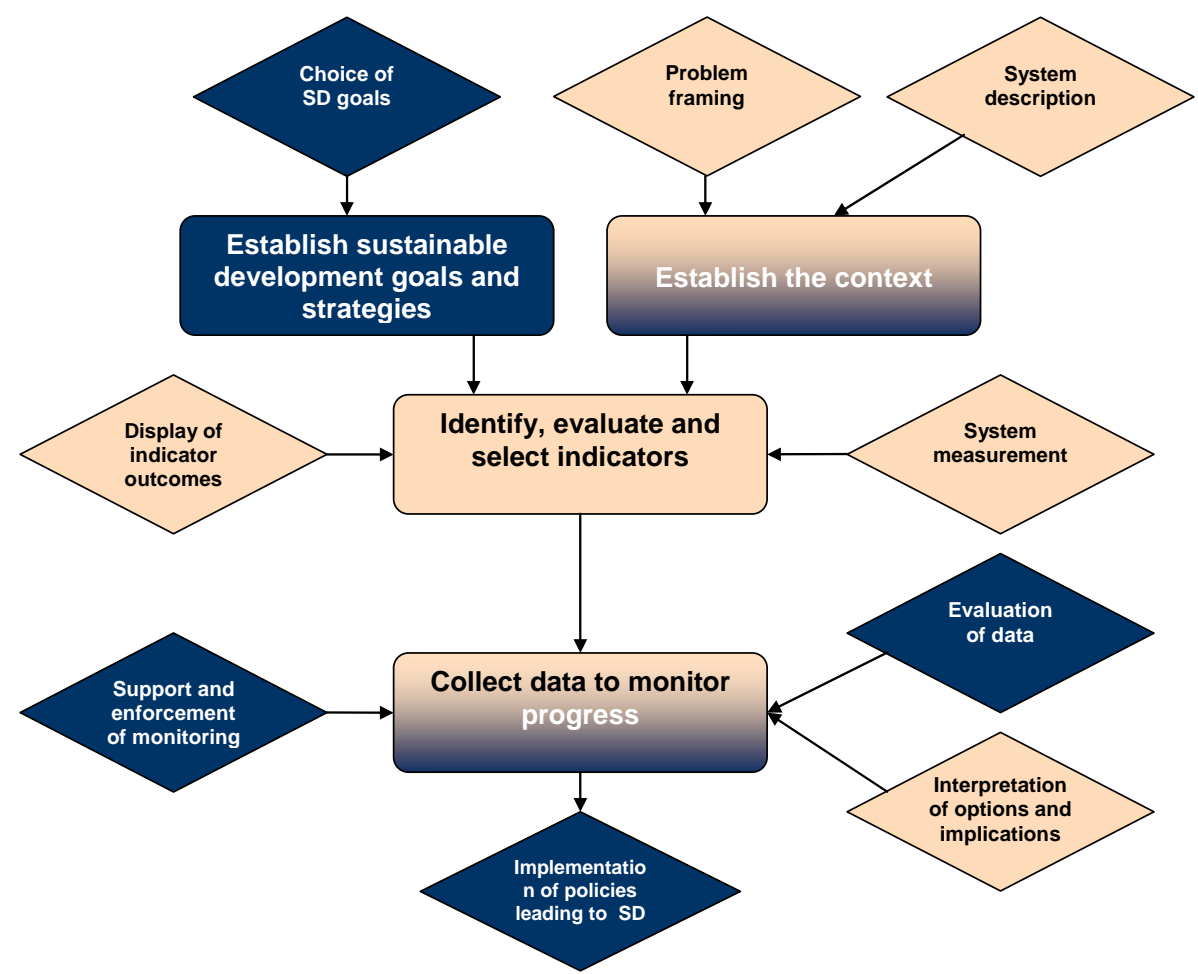

Figure 6.1: The role of policy and science in the various stages of monitoring sustainable development (policy in dark grey, science in light grey, steps in the process in rectangles, roles of actors in diamonds).

It merits noting that the various roles are not strictly separated, but are instead fluid. To conduct a proper monitoring exercise, it is important to be aware of the roles of different actors, the steps in the process, and the degree of complementarity among them. Such an exercise is a complex affair that requires the knowledge and involvement of numerous stakeholders throughout the process.

\subsection{Using indicator frameworks}

Numerous organizations such as the European Union (EU) and the United Nations Commission on Sustainable Development (UNCSD) have developed indicator frameworks on sustainable development, each reflecting the key sustainability issues for a particular scale level. For instance, the EU indicator framework is set up to monitor the implementation of the EU Sustainable Development Strategy (EU SDS) at the national level (EU, 2005c). The UNCSD Indicators of Sustainable Development aim to monitor the national implementation of Agenda 21, the Johannesburg Plan of Implementation, and the Millennium Development Goals (UN, 2007). In other words, an indicator framework generally addresses a certain institutional 
perspective on sustainable development and a set of political priorities for action and focuses on a certain spatial scale. Each framework is an expression of a "political agenda that identifies the priority elements of a specific sustainability policy" (INSURE, 2007b). Moreover, indicator frameworks are not always transferable to other parts of the world, to other perspectives on sustainable development, or to different scale levels. It is therefore important to be aware of the purpose for which a specific indicator framework is being designed.

In the INSURE project, we used the EU indicator framework as a political expression of sustainable development. The aim in this case was to develop a method that included regional characteristics in an indicator framework in such a way that the relative importance of each indicator within the regional system was made visible. This approach permitted a comprehensive picture of the region's dynamics, including its strengths and weaknesses. The EU indicator framework provided the necessary context and goals on sustainable development. Because we used this particular scheme, it is worthwhile to briefly highlight its history and focus.

To appreciate the emergence of the EU indicator framework, we need to go back to the introduction of sustainable development as an explicit objective of the European Community as it was expressed in the Single European Act of 1987. Over the subsequent two decades, many regional meetings have taken place to foster a political commitment toward sustainability. At the Gothenburg Summit in 2001, EU member states agreed that the economic, social, and environmental effects of all policies should be examined in a coordinated way and taken into account in decision making. The European Council identified ten priority areas for sustainable development as general guidance for policy measurement and development. ${ }^{17}$ This set of concerns is reflected in the EU sustainable development indicator scheme: (1) economic development; (2) poverty and social exclusion; (3) aging society; (4) public health; (5) climate change and energy; (6) production and consumption patterns; (7) management of natural resources; (8) transportation; (9) good governance; and (10) global partnerships (European Commission, 2004).

\subsection{The INSURE method: lessons from Limburg}

As mentioned above, the main goal of the INSURE project was to find regionspecific indicators and to combine them in such a way that they could provide an integrated view of regional sustainability. We used the EU indicator framework to provide the political context and vision on sustainable development and to estab-

\footnotetext{
${ }^{17}$ The European Council comprises the heads of state or government of the member states belonging to the European Union and the President of the Commission. It came into being in 1974 and was given formal status by the Single European Act. Its members are assisted by the respective ministers for foreign affairs and by a member of the Commission. Since 2000, in accordance with the Lisbon strategy, the European Council addresses economic, social, and environmental issues (see http://europa.eu/european-council/index_en.htm).
} 
lish a basis for comparison for four case studies. However, the EU framework is structured in a hierarchical way with themes, subthemes, headline indicators, and so forth. We wanted to obtain a meaningful picture of sustainability at the regional level, with indicators characteristic of the region. It was obvious that the EU indicator framework would not always match regional features. This situation not only implied the use of regionally collected data for the predefined indicators, it also meant using different indicators altogether for the themes in the framework.

One could reasonably ask why we went through this difficult manoeuvre to measure regional sustainable development. Why not develop a customised framework for each case study? First, comparability among case studies would have been impossible with different frameworks incorporating inconsistent priorities and goals for each region. Second, the point was not to design a framework for each region, but to provide a generic approach for measuring sustainable development without following the standard approach of predefining a universal indicator set. Finally, the aim was not to design the context and goals for each region, but to show that defining them is an important step for measuring sustainable development. The project operationalised the context and goal-setting step by using an existing political expression of sustainable development.

We next conducted a qualitative systems analysis (QSA) of the region to establish the context. A broad regional picture was thus obtained using the EU indicator framework as a filter for detailed analysis. It pointed to those areas that were important for the EU's sustainability goals. It should be noted that a different framework could have conceivably focused on other elements of the regional system. To see how this situation could have occurred, just imagine two different perspectives on sustainable development: an ecological perspective that places great emphasis on regional carrying capacity and a well-being perspective that stresses social health. Within each view, different parts of the regional system would become more or less important.

For those areas highlighted within the region, indicators were sought. A second requirement was that the indicator needed to provide insight into the state of an influential element in the regional analysis. Influential means here an element that has a notable impact within the system or, in other words, that is an important driving force. For technical details on determining influence, readers are encouraged to consult the INSURE website. ${ }^{18}$ The reason behind this second requirement was to enable us to evaluate the indicators in relation to each other. The influence within the system was used to weight the indicators so that we could judge, for example, the relative importance of congestion in relation to decreasing agricultural land use.

\footnotetext{
${ }^{18}$ http://www.icis.unimaas.nl/projects/insure
} 


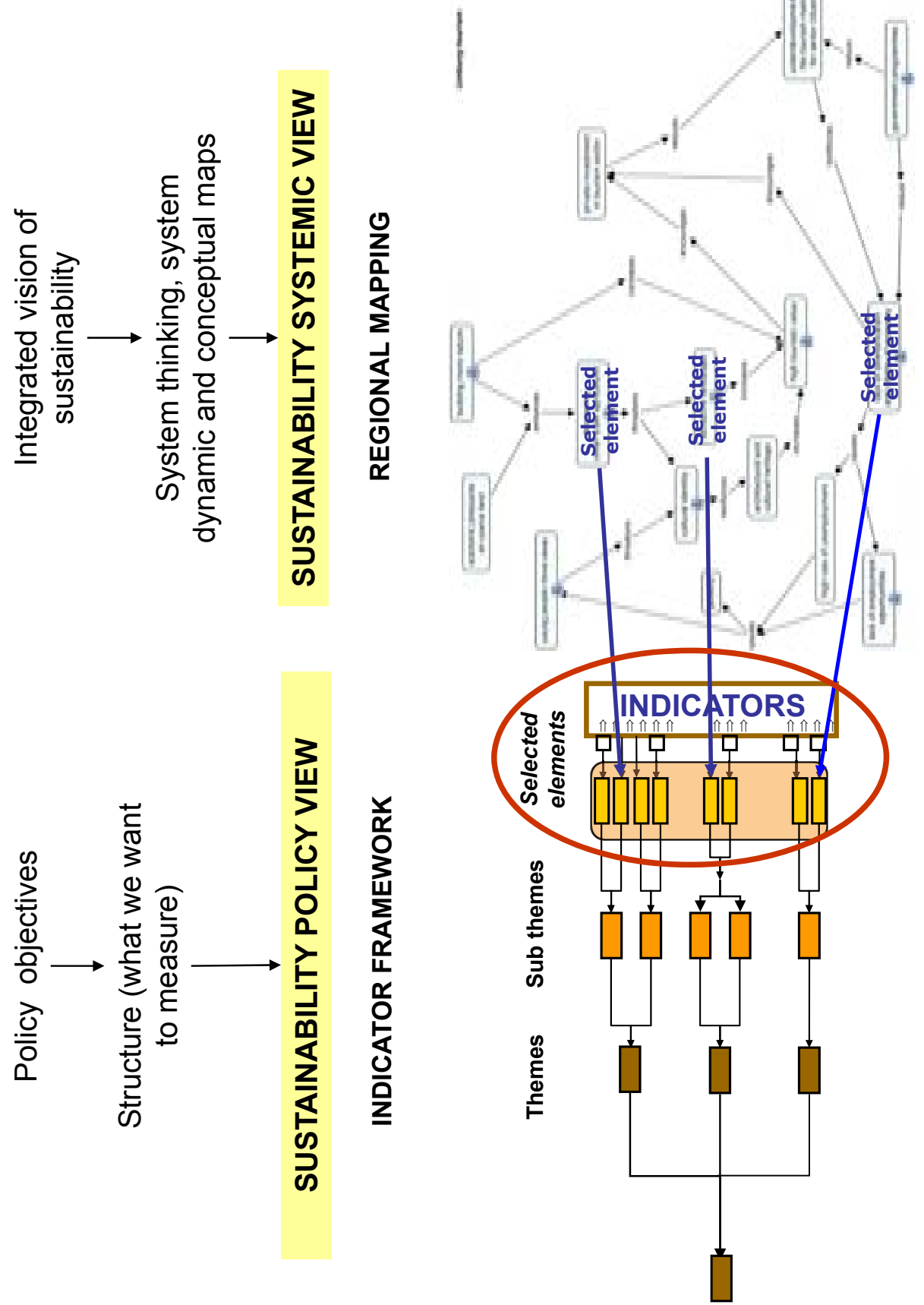

Figure 6.2: Combining the sustainability policy view (on the left) as expressed in an indicator framework with the sustainability systemic view (on the right) represented by a system map of the region showing relations between regional elements (adapted from INSURE, 2007). 
Essential for the method described here is the interpretation of an indicator within the system. It is not uncommon to encounter long lists of indicators that tell us nothing about their respective roles and functions in sustainable development (Province of Limburg, 2005c; Provincie Limburg (Belgie), 2006). For example, Eurostat, the statistical bureau of the European Commission ${ }^{19}$, struggled in its 2007 progress report with how to derive an overall picture of progress toward sustainable development using eleven headline indicators (Eurostat, 2007). In another case, the UNCSD guidelines on indicators recommended using simple symbols suggesting forward or backward movement on each element to communicate the direction of progress on sustainable development in a particular country (UN, 2007). However, neither the European Commission nor the United Nations discusses how individual indicator values might provide a comprehensive picture of sustainable development that takes into account the varying importance and systemic impacts of each indicator within the system. By contrast, the INSURE project demonstrated the relative importance of an indicator in relation to other indicators and how it contributed (or not) to sustainable development.

The value of the indicator tells us something about an element's state or trend. The importance of the indicator gives it a certain weight in the regional sustainability assessment. We aggregated this information into a dashboard view, where the colour signals the indicator's state and the width of the wedge represents its weight. Moving from the outside to the centre, the values are then aggregated into sub-themes and then themes, with an overall impression of sustainable development in the centre (Figure 6.3). The lower aggregation levels in the outer ring, as well as the qualitative systems analysis, are important for identifying a system's sustainability problems.

As an example, we interpret the results of the discourse analysis in Limburg with the EU framework as the definition of sustainable development (Figure 6.3). A striking result of this integrated sustainability assessment is that the region seems to be doing quite well with respect to economic development. Even a very negative value for the land-prices element is smoothed out by other positive and influential elements at the next level. This observation appears to contradict most reports that contend that economic development is lagging in Limburg (e.g. Province of Limburg, 2005d; 2006; Province of Limburg, 2007b). We can understand this apparent contradiction in the following terms: the dashboard shows regional trends, but does not indicate how far away the current situation is from the sustainability goals.

\footnotetext{
${ }^{19}$ The European Commission is the EU's executive body. It represents and upholds the interests of Europe as a whole, drafts proposals for new European laws, and manages the day-to-day business of implementing EU policies and spending EU funds. The Commission also makes sure that everyone abides by European treaties and laws. See http://europa.eu/abc/panorama/howorganised/index_en.htm
} 


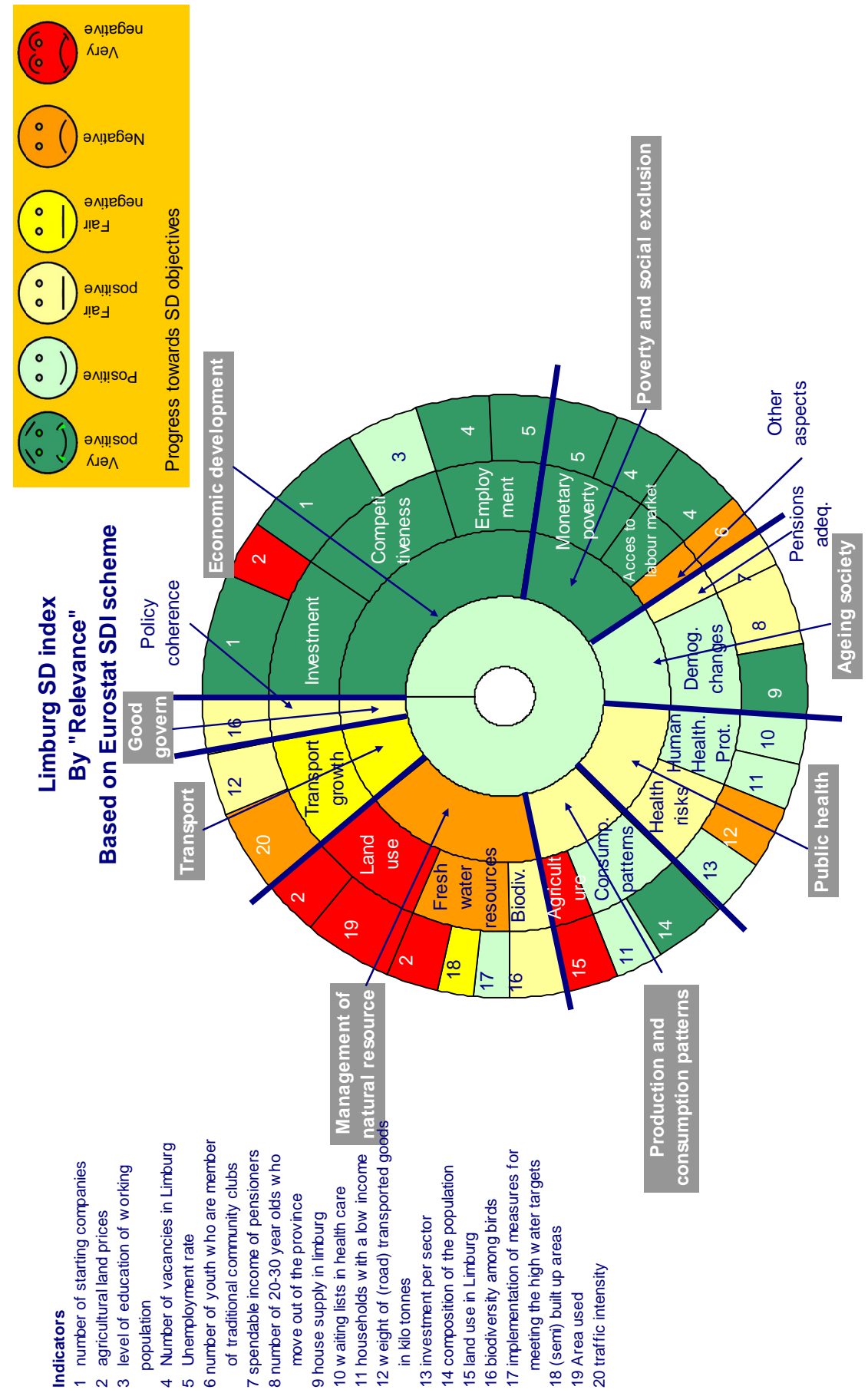

Figure 6.3: The dashboard overview of sustainable development in Limburg for the EU-SDI framework. 
The economic development trend in Limburg was strong at the time of the analysis (2004-2007) and therefore was represented positively in the dashboard, but analysis showed that regional economic development is still far from its potential (INSURE, 2007a).

In Limburg, poverty and social exclusion are decreasing and the aging of society, as well as public health, shows a positive to neutral trend, meaning that pensions are sufficient, poverty is under control, and health care is adequate. Production and consumption patterns are not having negative effects on sustainable development. However, attention should be given to the effects of the transportation sector on public health. More transport will lead to more congestion with negative consequences on air quality and people's health. More traffic will also cause more health risks due to accidents. In addition, the decrease in Limburg's agricultural area is a negative development, especially for the south of the province, because it not only affects the production and consumption of regional products, but also changes the landscape. The small scale landscape is a product of current and past agricultural activities. The resulting landscape with hedgerows and attractive farms contributes to the region's value as a tourist destination. Under the theme "management of natural resources" we observe negative trends. A combination of economic pressure on scarce land, declining agricultural subsidies, demand for more roads and houses, and land scarcity influences fresh water resources and land use. Although transportation is a growing sector, it is slightly negative due to increasing congestion. The overall value of the dashboard shows a moderately positive development of Limburg toward European sustainable development goals.

From this assessment we learn that at a higher levels of aggregation in the dashboard (i.e., the rings closer to the centre, representing the subtheme or theme level) the prevailing development trend is generally positive. However, policy makers should devote attention to the areas highlighted in the outer ring where there are signals of specific problems. A system analysis of the region can provide further insight into these underlying dynamics. In this case, the framework clearly focuses on certain issues considered problematic for sustainable development within the European context, such as an aging society or poverty and social exclusion.

\subsection{A regional framework}

The previous section described how Limburg is doing in the field of sustainable development from an EU perspective. However, some important elements from the general regional systems analysis could not be accommodated in the EU framework (e.g., transboundary drug dealers, cultural identity, and architectural and cultural heritage). This situation means that certain elements were not considered important for that specific (political) view on sustainable development, although they were important for the region (based on the QSA results). The EU 
priorities were not necessarily regional priorities. Similarly, some themes of the EU indicator framework were not relevant for Limburg and were disregarded. For instance, the condition of the marine environment did not apply as Limburg is land locked. This observation highlights why in terms of some criteria the EU framework is inappropriate for conduct a sustainability assessment for the region.

Accordingly, the regional administration wanted to conduct a sustainability assessment from a perspective that would enable it to fulfil a biennial monitoring requirement. An expert group consisting of provincial administration staff was asked to conduct an assessment using the INSURE method. Completing this task required the use of a meaningful indicator framework that could be adapted to a regional scale and that was made or adapted specifically for Limburg. A regional framework can be a tool to follow up on progress toward the current political agenda on regional sustainability or a set of particular regional concerns. However, comparability among the development of different regions considerably decreases when a regional framework is used because every region introduces into the framework its own priorities and key issues (INSURE, 2007b).

A regional framework of sustainability indicators did not exist for Limburg, so one had to be designed. When we started developing this framework within the context of the biennial exercise of monitoring the status of the province, the Limburgmonitor, it became clear that policy makers lacked a long-term vision on regional sustainable development. On the basis of various policy documents, it was at best possible to assemble a partial vision. According to the provincial administration "Sustainable development has in theory five dimensions: ecological, economic, socio-cultural aspects, long-term effects and effects elsewhere. Furthermore . . . development must take place in such a way that the value of each form of capital increases and that the increase of one type of capital does not reduce the value of the other capitals." (Province of Limburg, 2005a) (translation by author).

A self-evaluation by the province of its sustainability policy (2005-2007) stated that measurable goals and related indicators had not been identified because the program emerged only during the government period of 2003-2007. Therefore, regional officials could not draw any conclusions on the policy's success (Province of Limburg, 2007a). The current coalition agreement, a document that describes the overall political priorities for the period 2007-2011, explicitly recognizes the first three domains cited above (i.e., ecology, economy, and society) and their interconnectedness and regards sustainable development as an important pathway (Province of Limburg, 2007b). However, sustainable development is not made concrete and is not supported by clear goals.

As a consequence, the expert group working on regional monitoring did not want to interfere with what its members saw as a role for policy makers by setting their own priorities for sustainable development in Limburg. Therefore, the regional 
framework remained rather indistinct and was based simply on the three pillars of sustainable development: society, economy, and ecology. Furthermore, the absence of sustainability goals and criteria for interpretation became a major barrier to conducting a successful sustainability assessment. This problem could not be overcome by using an expert group that had no political mandate for defining sustainable development in this regional context because it was neither representative of the population nor an elected body with delegated powers from the residents of Limburg. Due to the absence of policy-making input into the process, problems arose at several stages (see Figure 1).

As a spin-off, we confirmed in this project that at all stages of measuring sustainable development, the involvement and cooperation of relevant policy makers and technical experts/scientists is essential. With hindsight, we must admit that enhanced cooperation among these participants from the beginning would likely have led to a more meaningful assessment.

\subsection{Discussion}

The previous sections have demonstrated the importance of linking science and technical expertise with policy in integrated sustainability assessment and the problems that arise if these roles are not effectively fulfilled. However, several questions remain. What recourse is there when a vision of sustainable development is not available? Is an indicator framework truly an expression of a political vision of sustainable development? Can a systemic analysis be regarded as neutral, or is it also an expression of a certain vision? And to what extent should stakeholders be involved? The following sections consider each of these questions in turn.

\section{Missing vision}

Without a vision of sustainable development, an effective statement on sustainable development is hard to articulate. To say something meaningful on this subject with respect to Limburg, it is first necessary for the government or another representative body to provide such a viewpoint. Once the goals have been made explicit, it is possible to start to measure the distance that needs to be travelled. However, as Reed et al. (2006) mention, most often indicator exercises start with the identification of indicators. For Limburg, the EU sustainable indicator framework provided sustainability goals, but regional sustainable development goals were lacking. With good reason, the provincial experts did not want to take on the role of policy makers in setting priorities for the region with respect to sustainable development. We therefore employed a rather simple, indistinct vision of sustainable development: the three-pillar approach, which is so common and is already being used in Limburg that the expert group deemed everyone could live with it. 
But when deciding on the logic of what was advantageous or disadvantageous for sustainable development, we ran into problems. The three-pillar approach is so general that it is open to multiple interpretations. As a result, we had difficulty discerning a regionally appropriate set of indicators, demonstrating that a sustainable development vision and goals are extremely important.

\section{Neutral indicator framework?}

In our research, we have used the EU indicator framework of sustainable development as an expression of a European vision of sustainable development. But is this projection really a policy-based viewpoint, or rather a framework conceived by experts based on their ideas of sustainable development? If we read McCool \& Stankey (2004) carefully, their stance is that frequently the search for indicators is an ad hoc process, hardly related to any framework. Therefore, when using an existing indicator framework, it is legitimate to ask who created it and whether policy makers have endorsed it. If it has received such validation, we can assume that it indeed fits policy makers' contemporary ideas of sustainability. In the case of the EU, the European Commission has adopted this framework. ${ }^{20}$ Steinbuka \& Wolff (Steinbuka and Wolff, 2007) state that "The list of [sustainable development] indicators itself is not defined, although it is foreseen that a limited set of indicators could be adopted by the European Council by the end of 2007. This solution was preferred by most stakeholders, as it avoids freezing a list of indicators, and allows more flexibility in its improvement and development over time."

As official EU monitoring reports using this framework appear regularly, we can assume some kind of agreement that it provides an appropriate way to assess sustainable development that is in line with EU policy objectives. However, we can also think of scenarios where policy makers have commandeered scientists and other experts to build indicator frameworks and have simultaneously delegated to them the role of defining a vision of sustainable development. We have personally fielded comments that, as scientists or other experts, we should be able to define sustainable development. However, if we review existing literature, it is clear that numerous definitions exist and not one is fully acceptable to everybody (cf. Burger, 2006; Parris and Kates, 2003; Robinson, 2004; Sneddon et al., 2006). It is, therefore, safe to say that sustainable development is a normative concept and not an issue that can be defined by science (Zeijl-Rozema van et al., 2008). Science can help in formulating the vision by showing how certain ideas might be in conflict or by formulating scenarios of possible developments. Science can also make sustainable development politically decidable, for instance by analysing different scenarios. However, it is up to society, represented by elected politicians and stakeholder groups, to decide on a broad vision of sustainable development and the sustainabil-

\footnotetext{
${ }^{20}$ See http://epp.eurostat.ec.europa.eu/portal/page/portal/sdi/introduction
} 
ity of the various pathways. Of course, scientists can provide theoretical models and empirically sound methodologies. In addition, scientists have vital roles to play in supplying intellectual and conceptual frameworks along with critical and analytical perspectives. They can also offer leadership in projects as independent facilitators and mediators; assure transparency, credibility, and robustness to sustainable development processes; provide technical expertise; supply knowledge about data sources and their use; and afford access to international networks (Mickwitz and Melanen, 2009; Ramos, 2009; Zilahy and Huisingh, 2009; Zilahy et al., 2009).

\section{Systemic analysis and vision on sustainable development?}

We also inquire about the extent to which a systemic analysis incorporates a hidden vision of sustainable development. The description used for Limburg was formulated in two different ways: through a discourse analysis and by means of an expert group. Each mode resulted in a different description. This variation does not pose a problem if there is clear acknowledgement which group described the system and an understanding of possible biases. For instance, the discourse analysis was based on policy documents so the prevailing political view will be reflected in the system description. The expert group was restricted to staff of the provincial administration. Although this was a multi-sector group, it was not a multistakeholder assemblage of people. The knowledge and worldviews of the participants determined the system description and therefore gave shape to the systems analysis. The analysis will reflect their ideas about what facilitates sustainable development and what obstructs it. However, ensuring the participation of a multidisciplinary team, preferably from different stakeholder groups (e.g., state, market, civil society), will help to form a general idea of the system. A typical political view, in contrast, will pinpoint several areas for action and leave out others. In conclusion, a systemic analysis is by no means objective, but it forms an impression of a system at a certain scale.

\section{Stakeholder involvement}

As was mentioned earlier, sustainable development monitors should include representatives of state, market, and civil society. The composition of these stakeholder groups might differ at various stages in the process because different roles have to be fulfilled at each phase (Figure 6.1). An essential aspect of the participation process is that stakeholders view their involvement as making a difference because otherwise there is no incentive for them to participate (Pirk, 2002). It is also essential to clarify from the beginning what issues are under consideration, who will make the final decisions, and why and how stakeholders are involved (MPA (National Marine Protected Areas Center), 2004). In the INSURE project, we were developing a method and finding our way in an experimental setting. In such a process, stakeholders might feel lost or lose interest, as we encountered at an earlier 
stage with staff at the provincial administration of Limburg. With the insights gained during this project and experience acquired deploying this method, we would likely be able to organize a more meaningful participatory monitoring process that follows more closely the guidance of Figure 6.1.

\subsection{Conclusion}

The measurement of regional sustainable development requires several elements: a capacity for flexibility that includes a set of region-specific characteristics, a proper system description, and a vision of sustainable development that determines regional priorities. Once these prerequisites are in place, it becomes possible to assess regional sustainability. From this study, we can conclude that a systems analysis from a sustainability perspective is different from an indicator framework that points at political priorities for sustainable development. However, it is necessary to draw on the systemic view to determine relationships among indicators and their relative importance in the system. It is also important to incorporate the political view to provide the context for deciding what is to be measured and how it should be interpreted.

Based on the results of the Limburg case study, we advance six summary conclusions about integrated monitoring of sustainable development and the barriers that occur. First, it is important to link science and policy throughout the whole assessment process. Scientists and policy makers have different roles to play and they contribute different insights (see Figure 6.1). An assessment carried out by only one group will lead to problems. In the case of an exclusive scientists/expertsrun assessment, the normative aspect and social representativeness of sustainable development will be understated. In a policy maker/society-run assessment the transparency, credibility, and robustness of methods and data collection might not be adequately safeguarded (McCool and Stankey, 2004).

Second, the leader of the assessment should always deploy a multi/transdisciplinary team, preferably from different stakeholder groups (e.g., state, market, civil society) to formulate a general overview of the system. These three major groups play different roles within the region and are needed to design general understanding of sustainability and the regional dynamics. The composition of the team might have to change at various points in the overall process.

Third, the organisers should make explicit a sustainable development vision for the assessment. Until agreement is reached on what it is that should be sustained - by government or, ideally, by participation of (representatives of) the region's population- it is impossible to identify relevant and valid indicators. In the absence of structures to establish such a vision, the preparation of a satisfactory assessment becomes extremely difficult. 
Fourth, the sustainable development filter, or perspective, used to analyze data, has a large impact on the results of the assessment. Related to this point, it is vital to use an indicator framework suited to the purposes of the assessment, to understand what the indicator framework measures, and to be aware of the sustainability perspective used, as this will lead to different priorities for measurement and thus alter results.

Fifth, it is important to relate indicator results to sustainability goals and to ensure that the results are interpreted within the context of the system. An indicator just indicates. An indicator becomes meaningful only when it is seen in the light of a norm, a threshold, or a criterion for analysis. But even under these circumstances, an indicator in isolation does not provide information about sustainability. It is only by relating a particular indicator to other measures and evaluating its importance within the system that we can make a meaningful sustainability assessment.

Finally, when conducting an assessment decision makers should give attention to negative results even if the overall picture is positive. The dashboard view demonstrates how a positive trend at a higher aggregation level could hide negative trends at lower levels. These are signals of underlying sustainability problems and deserve attention. Furthermore, it should be kept in mind that the dashboard shows trends, not the divergence between the current situation and the desired situation. It would be better to show this discrepancy. However, the desired future is largely undefined in the cases of both the EU and the regions, which means only the current situation can be shown.

The INSURE project sought to design a generic framework for determining the sustainability of a region while allowing flexibility to include regional characteristics. The work done in Limburg demonstrates that scientists/experts and policy-makers can feasibly be involved in the process. Furthermore, to make a meaningful sustainability assessment it is crucial to create links between the political/social sustainable development vision and the scientific understanding. 


\section{Comparing region-specific sustainability assessments through indicator systems: feasible or not?}

Based on Zeijl-Rozema van, A., Ferraguto, L., Caratti, P., 2011. Comparing regionspecific sustainability assessments through indicator systems: feasible or not? Ecological Economics 70: 475-486 (Zeijl-Rozema van et al., 2011)

\subsection{Setting the scene}

Numerous indices help us to compare country and local performance in the field of human development (UNDP, 2007), globalization (Martens and Raza, 2009) and sustainable development (Bartelmus and Douglas, 2008). Furthermore, existing indicator sets (EU, 2005c; UN, 2007) allow us to measure sustainable development in many different places and to compare the results. Obvious problems arise, such as data availability and data quality. In the previous chapter we investigated the possibilities for integrated monitoring of regional sustainable development. We saw that region-specific characteristics are linked to the sustainability targets of the territory and reflect the political decision space in which they are adopted. This chapter investigates the possibility of comparing regional sustainability assessments in four case studies, where the indicators vary from region to region, but the method of making the assessment is similar. Through the analysis of the results of the INSURE project, we will explore the possibility of producing an integrated indicator framework that reflects the specificities of each region without compromising the completeness of the information provided, or the comparability of the different outcomes. This chapter contributes to answering the question on how sustainable development can be monitored in an integrated way, and what barriers occur.

\subsubsection{Comparing regions}

We should start by explaining why there is a need for comparison at the regional level. Regions in Europe progressively get more attention. During the informal ministerial meeting in Leipzig in May 2007, the EU Ministers for Spatial Planning have emphasized in the Territorial Agenda of the EU "their intention to preserve the regional diversity of the European Union in the further course of the EU integration process to make use of the regional identity by considering it a valuable asset in the development of the regions in Europe and to promote complementarities and synergies between the different territories.". (EU, 2007) Furthermore, the Territorial Agenda states that the territorial integration of inhabited spaces is a way to contribute to a Europe that is culturally, socially, environmentally and economically 
sustainable (EU, 2008a). In other words, regions are progressively seeing their scope and function within EU widening, from the implementation of a merely economic agenda to a more integrated agenda of sustainability (Ravetz, 2004). Thus, an assessment provided at the regional scale level is important to signal specific strengths and weaknesses to the national and European level in order to improve policy effectiveness.

However, previous research has shown that existing regional sustainability assessments are frequently flawed by a fuzziness in goals and establishing of objectives, uncertainty in the identification of causal linkages and an obvious difference in unique initial socio-cultural conditions (Ravetz, 2007). Furthermore, given the existence of a multi-level, multi-actor and multi-sector governance configuration in sustainable development, single assessments produced at the regional level run the risk of remaining isolated if they are not evaluated under general policy criteria fixed at a higher level. (Morgan, 2004) This introduces the issue of how policymakers and practitioners can identify analytical and evaluation tools that permit to compare sustainability performances of different territories, taking into account singular distinctiveness, but at the same time leading to useful indications on how the goals defined at a higher level (national, European, and global) are complied with over time.

Considering such issues, it is important to highlight that in recent years European Institutions have made an increasingly extensive use of "soft" policy coordination approaches (e.g. Open Method of Coordination and the Sustainable Development Strategy) in order to create coherent policies under a common framework, where stringent policy targets cannot be imposed or are inopportune. (Bruno et al., 2006) Current adoption of benchmarking techniques aimed at comparing different performances, processes or policies to promote learning has however, shown crucial flaws in that it has been essentially devised as "one-size-fits-all" models, disregarding potential differences. (Huggins, 2008) In this sense there is a need to adopt evaluation techniques which assess the degree of correspondence with the goals fixed at the higher levels, while at the same time leaving more space for manoeuvre to the single regions or States involved. (Begg, 2009)

In the INSURE ${ }^{16 \text { (see footnote in section 6.1) }}$ project a sustainability assessment of four European regions was conducted by means of a flexible framework allowing for inclusion of regional characteristics. This chapter investigates to what extent the resulting assessments are comparable. A challenge is to compare similar issues in case studies that use different indicators.

\subsubsection{Structure of the chapter}

In section 7.2 we will discuss some comparability issues, such as the role of indicator frameworks to make assessments more comparable, the aggregation and normalization of indices, the normativity of sustainable development and its implica- 
tions for measuring sustainable development. Section 7.3 briefly explains the concepts behind the three tools that jointly form the INSURE toolkit. Comparability of the tools is then discussed with a brief overview of commonalities and specifics of the four regional case studies in Europe ${ }^{21}$. Section 7.4 addresses several remaining challenges and is followed by general conclusions on their comparability in section 7.5. For a detailed description of the case studies in which the method is explained in more detail, we would like to refer to two publications on the Lombardy and Limburg case studies. (Caratti and Ferraguto, 2008; Zeijl-Rozema van and Martens, 2010)

\subsection{Comparability issues}

\subsubsection{Indicator frameworks}

Comparability is often a primary goal of sustainability assessments: either comparing performance against previous years, comparing progress towards certain goals or comparing performance between entities (e.g. companies, municipalities, regions, and countries). A main trend in developing indicator sets can be identified: the construction of sets of indicators organized within a framework, which can eventually aggregate the separate indicator results. (Ronchi et al., 2002)

Indicator frameworks are often designed in order to provide an integrated and comparable measurement of the sustainability situation in a given area. (Noll, 2002) In such indicator frameworks, common reference may be the benchmark of best performers, or previously fixed goals. In this sense, their importance is maximized by the existence of common targets to all case studies, which can therefore be judged against the same criteria. (JRC, 2002)

Other tools, instead, use an approach of relative targets, in order to measure the distance between the actual developments of the study unit and each target, combining them with the existence of a normative theory of sustainable development. (Pareglio et al., 2005)

Furthermore, the frameworks can be differentiated by their construction: they are either built around a specific conception of sustainability (see, for instance, Human Development Index), or they are integrated starting from a list of key indicators which are sequentially aggregated. (Jesinghaus, 1999) It is always important to realise that an indicator framework presents as such a normative choice for what sustainable development is: some things are included and some not. The EU framework that is used in this article represents also a normative choice for a certain view on sustainable development. Moreover, Van Zeijl-Rozema and Martens (2010) say that "indicator frameworks are not always transferable to other parts of the world, to other perspectives on sustainable development, or to different scale

\footnotetext{
${ }^{21}$ Antalya (Turkey), Limburg (The Netherlands), Lombardy (Italy), and Pardubice (Czech Republic)
} 
levels. It is therefore important to be aware of the sustainability perspective that is being used."

\subsubsection{Comparison issues}

Building a definite framework or aggregating indices, however, presents some problematic issues which may limit their comparability.

In the first place, where composite indices are adopted, compensability among different indicators is always assumed, so that a decrease in one dimension of sustainability can be always overcome by an increase in another, which is not always possible. (Munda, 2005) Sustainability indicators and indices built this way do not take into account fundamental issues such as the non-substitutability of some functions, or the inherent conflict between environmental conservation and economic growth. (Hueting and Reijnders, 2004)

Secondly, most of the indices apply a normalization of the variables included within, in order to make them comparable. Normalization is by no means a neutral process, since it entails a value judgment in order to provide a common basis to evaluate different measures. This operation, however, can produce very different conclusions and have profound consequences on comparability over time and over different units, depending on the way it is operated. (JRC, 2005) Where most indicator systems fail, in this case, is in providing systematic assumptions under their choices for normalization, which then is bound to result in arbitrariness. (Böhringer and Jochem, 2007)

Thirdly, indicator frameworks and indices are not merely technical or impersonal measures, as they reflect what the community and institutions behind them mean by sustainable development. (Astleithner et al., 2004; Miller, 2007) Assuming different definitions of sustainability leads to different evaluations of performances, depending on the metrics and the focus adopted by the framework (Wilson et al., 2007; Zeijl-Rozema van and Martens, 2010), as well as on the preference towards single dimensions of sustainability (Mayer et al., 2004).

These basic constraints have thus led some authors to argue that the assessment of sustainability should be one of "weak comparability". (Martinez-Alier et al., 1998; Spangenberg, 2005) These authors postulate the impossibility of adopting a concept of "strong commensurability" (i.e. reduction of a variety of values to a single metric such as monetary value) of elements in a sustainability evaluation, because reducing complex systems and different dimensions to a single unit would mean to assume that they serve a unique function, and thus can be considered as substitutes. (Spangenberg, 2005) Martinez-Alier et al, (1998) state that ' [ . . . ] an effective assessment, in order to be realistic, should consider not merely the measurable and contrastable dimensions of the simple part of the system [ . . . ]. It should deal as well with the higher dimensions of the system, those in which power relations, 
hidden interests, social participation, cultural constraints and other 'soft' values become relevant [ . . . ] variables [ . . . ].'. They conclude that incommensurability does not imply incomparability, but weak comparability, which can be operationalised by means of multi-criteria evaluation.

In other words, the solution to the problem of comparing different objects through indicators calls for two major changes in the current analyses. The first one is to move from designing a framework for structuring the indicators to more integrated systemic models that allow the analysis of the complex dynamics underlying sustainability. (Grosskurth and Rotmans, 2005) The second is to evaluate sustainability by means of an assortment of tools (Mayer, 2008), which permit to give a complete glance over performances to include all the components of sustainability.

\subsubsection{INSURE}

The EU funded project INSURE developed a flexible methodology for representation, analysis and evaluation of sustainability at the regional level. INSURE aimed to develop a practical and ready-to-apply method and toolkit for working with regional sustainable development indicators. An important element was to search for a way to deal with sustainable development at the regional level so that regional stakeholders could work with the method. This implies that a choice has been made for simple rather than sophisticated tools. The vision of sustainability at the basis of the INSURE concept is that reality constitutes a systemic whole, where the entirety of units represents more than the mere sum of them, and where the events (i.e. relations of cause-effect) act as linkages between the units. (Jiliberto Herrera, 2006) Therefore, economic sectors, spatial development, environmental pressures and social trends cannot be expressed through their own languages ore be observed through sectoral analytical tools, since they are all interlinked and interdependent. Given this, adopting a systemic approach would permit to produce evaluations based on the context (Phillis and Andriantiatsaholiniaina, 2001) and would help policies and programmes to address the causes of deep-rooted problems rather than the symptoms on the surface (INSURE, 2003).

Especially at the regional level, the existing indicator frameworks do not permit to include relevant region-specific information. Furthermore, they do not provide comprehensive information on system sustainability. (Zeijl-Rozema van and Martens, 2010) Various authors propose an approach that allows for regional differences instead of applying generic standards. (Reed et al., 2006; Stevenson and Ball, 1998; Wallis, 2006) Another issue to be taken into account is that a region incorporates processes that go beyond the regional level. (McManus, 2008) Besides, "producing sustainable development indicators at the regional scale implies [ . . . ] additional problems in terms of data availability, data homogeneity for comparison 
purposes and adaptation of national or EU policy priorities to the regional scope". (Alvarez-Arenas and Miron, 2006) INSURE attempted to overcome some of these issues, in order to grasp the 'causes' with a more fundamental understanding of the region as a system.

Although comparing regional performances was not the first aim of the INSURE project, we wanted to investigate the potential to compare regions with this tool, given the fact that indicators differed between case studies. A potential for comparison would increase the usefulness of the tool and it might also serve as a basis for cooperation among regions. Our assumption was that the INSURE approach permitted to investigate comparability among regions through a common methodological basis instead of more rigid comparability frameworks using exactly the same pool of indicators or deriving an aggregated index.

\subsection{Comparing regions with the INSURE approach}

The INSURE toolkit is based on systemic thinking and systemic analysis. The systemic framework has at least two features that makes it suitable for the analysis of sustainable development: the study of trends and dynamics rather than single effects or events, which allows an analysis covering different time ranges (short-, medium- and long-term) and comparison of trends; and the focus on the interdependence of different factors, targeted at providing a coherent and systematic picture of the different dimensions underlying the concept of sustainability.

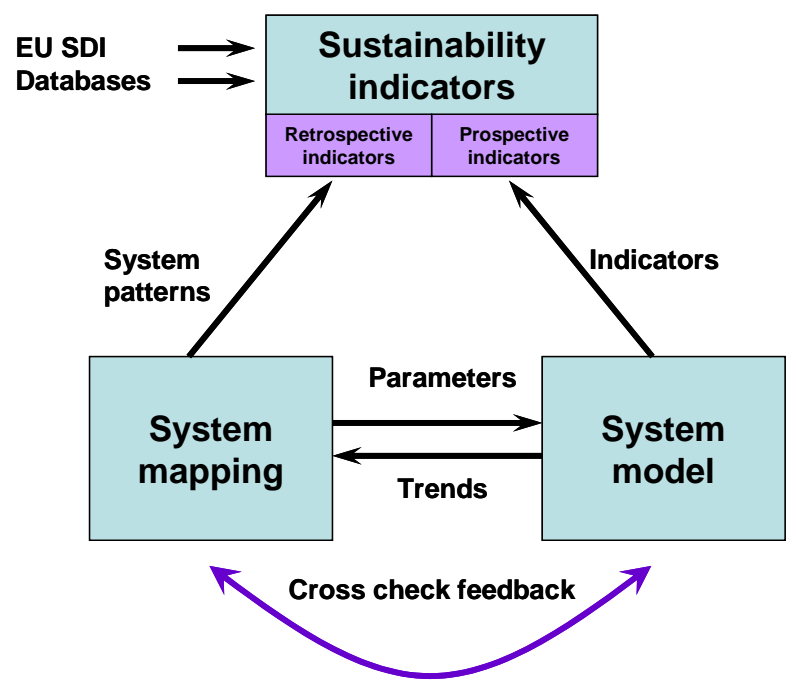

The INSURE toolkit consists of three interacting tools: system mapping, system modelling and system indicators, where the system mapping and modelling represent a systemic regional view and the sustainability indicators represent the political sustainability view.

(fig. 7.1).

Figure 7.1: The three tools interact and present different information that leads to a full assessment of each region. (Álvarez-Arenas and Mirón, 2006) 
When investigating comparability it is useful to briefly look at the different types of information each tool provides before comparing the regions. We see that although the three tools overlap to some extent, they also provide different types of information on the same region, thus creating a complete picture (table 7.1).

Table 7.1: The three tools compared (Caratti and Ferraguto, 2008)

\begin{tabular}{|c|c|c|c|}
\hline Main Features & System Mapping & System Model & System Indicators Tool \\
\hline Approach & $\begin{array}{l}\text { Qualitative: it assesses } \\
\text { the fuzzy interrelations } \\
\text { of the regional system } \\
\text { organized into "sustain- } \\
\text { ability discourses". }\end{array}$ & $\begin{array}{l}\text { Quantitative: it provides } \\
\text { indicators fed by statisti- } \\
\text { cal data and determined } \\
\text { by a set of equations. }\end{array}$ & $\begin{array}{l}\text { Policy : it is built as a hierar- } \\
\text { chical set of policy priorities, } \\
\text { which takes into account } \\
\text { representation of reality } \\
\text { which stems from the mod- } \\
\text { els. }\end{array}$ \\
\hline $\begin{array}{l}\text { Main functions } \\
\text { within the system }\end{array}$ & $\begin{array}{l}\text { Provides information in } \\
\text { the form of emergent } \\
\text { system patterns to the } \\
\text { System Indicator frame- } \\
\text { work. }\end{array}$ & $\begin{array}{l}\text { It provides perspective } \\
\text { indicators to System } \\
\text { Indicator. It is cross- } \\
\text { checked with System } \\
\text { Mapping. }\end{array}$ & $\begin{array}{l}\text { Incorporates qualitative } \\
\text { information from System } \\
\text { Mapping. It is also fed by } \\
\text { indicators derived from } \\
\text { System Model. }\end{array}$ \\
\hline Reference timeline & $\begin{array}{l}\text { Retrospective: it offers a } \\
\text { perception of the region } \\
\text { which is based on policy } \\
\text { documents, stake- } \\
\text { holders' point of view } \\
\text { and analysis. }\end{array}$ & $\begin{array}{l}\text { Perspective: it provides } \\
\text { forecasting of the sus- } \\
\text { tainability trends, based } \\
\text { on regional, national and } \\
\text { EU databases. }\end{array}$ & $\begin{array}{l}\text { Retrospective/Perspective: } \\
\text { based on most recent time } \\
\text { series for chosen indicators } \\
\text { for System Mapping informa- } \\
\text { tion, on perspective System } \\
\text { Model trends otherwise. }\end{array}$ \\
\hline $\begin{array}{l}\text { Comparability } \\
\text { between regions }\end{array}$ & $\begin{array}{l}\text { A similar way of con- } \\
\text { structing the QSA and } \\
\text { sustainability spectrum. } \\
\text { Discourses are region- } \\
\text { specific. }\end{array}$ & $\begin{array}{l}\text { The same model is } \\
\text { applied and the same } \\
\text { output indicators are } \\
\text { obtained. Region-specific } \\
\text { data-sets and parame- } \\
\text { ters are used. }\end{array}$ & $\begin{array}{l}\text { In this chapter, for compara- } \\
\text { bility reasons the same policy } \\
\text { framework was used (EU- } \\
\text { SDI). Indicators are region- } \\
\text { specific. }\end{array}$ \\
\hline
\end{tabular}

Because each tool creates different information, also the way this information can be compared between regions is different. In the following description of the tools and the findings from the four case studies, the issue of comparability of the results will be further discussed. The reason for comparing these case studies was not for a specific purpose such as allocation of funds or incentives for 'top scorers', but to investigate the potential for comparing regions with the INSURE method. Each of the four case studies represent very different regions with different characteristics (figure 7.2, table 7.2). 


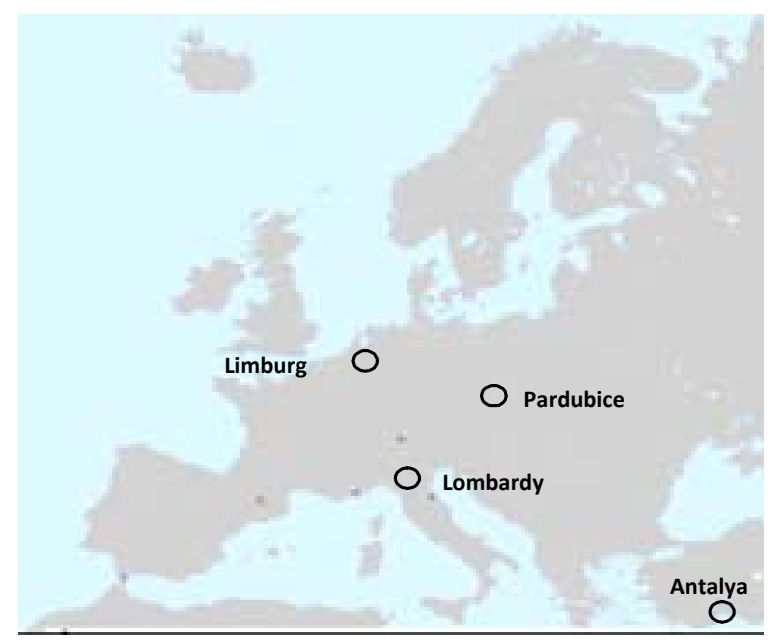

Figure 7.2: Location of the four case studies

Table 7.2: Regional characteristics of the four case studies (source for data: Wikipedia - Italian version, information retrieved online on July $20^{\text {th }} 2009$ )

\begin{tabular}{|c|c|c|c|c|}
\hline & $\begin{array}{l}\text { Antalya } \\
\text { Turkey }\end{array}$ & $\begin{array}{l}\text { Limburg } \\
\text { The Netherlands }\end{array}$ & $\begin{array}{l}\text { Lombardy } \\
\text { Italy }\end{array}$ & $\begin{array}{l}\text { Pardubice } \\
\text { Czech Republic }\end{array}$ \\
\hline Surface & $20,591 \mathrm{~km} 2$ & $2,212 \mathrm{~km} 2$ & $23,865 \mathrm{~km} 2$ & $4,519 \mathrm{~km} 2$ \\
\hline Population & $1,719,751$ & $1,142,737$ & 9.742 .676 & 506,000 \\
\hline Pop. dens. & $83,5 \mathrm{p} / \mathrm{km} 2$ & $516 \mathrm{p} / \mathrm{km} 2$ & $408 \mathrm{p} / \mathrm{km} 2$ & $112 \mathrm{p} / \mathrm{km} 2$ \\
\hline $\begin{array}{l}\text { Main economic } \\
\text { activities }\end{array}$ & $\begin{array}{l}\text { Agriculture, Ser- } \\
\text { vices, Industry, } \\
\text { Construction }\end{array}$ & $\begin{array}{l}\text { Industry, Trade, } \\
\text { Health care, Ser- } \\
\text { vices, Tourism, } \\
\text { Transport }\end{array}$ & $\begin{array}{l}\text { Services, Industry, } \\
\text { Trade }\end{array}$ & $\begin{array}{l}\text { Industry, Services, } \\
\text { Agriculture }\end{array}$ \\
\hline Special features & $\begin{array}{l}\text { Population increase } \\
\text { of } 4.18 \% \\
\text { Tourism very } \\
\text { important }\end{array}$ & $\begin{array}{l}\text { Industry } 19 \% \text { of } \\
\text { jobs, } 40 \% \text { of regional } \\
\text { production }\end{array}$ & $\begin{array}{l}\text { Lowest unem- } \\
\text { ployment in Italy } \\
\text { High number of } \\
\text { enterprises }\end{array}$ & $\begin{array}{l}\text { Nature } \\
\text { Increase in foreign } \\
\text { investors }\end{array}$ \\
\hline
\end{tabular}

\subsubsection{System mapping}

System mapping of a region consists of cognitive maps about the regional issues relevant for sustainability analysis. Cognitive maps are graphical representations of logical discourses that link - by means of boxes and arrows - elements or phenomena, establishing a causal relationship among them. (Jiliberto Herrera, 2008) Mendoza and Prabhu (2006) mention three soft system dynamics models - cognitive mapping, qualitative system dynamics and fuzzy cognitive mapping. INSURE's system mapping incorporates elements of both cognitive and fuzzy cognitive mapping. Such simple models create an environment where stakeholders can actively participate. The aim of INSURE is to provide a common understanding of the function- 
ing of the major elements constituting the regional system and their relations in terms of sustainability.

The system mapping, which is a qualitative systems analysis (QSA), can be done in a variety of ways, for instance by means of an expert group, a stakeholder group, or a desk study. "The knowledge and worldviews of the participants determine the system description and therefore give shape to the systems analysis. ( . . . ); by ensuring the participation of a multidisciplinary team, preferably from different stakeholder groups (state, market, civil society) a broad picture of the system will be formed.". (Zeijl-Rozema van and Martens, 2010) It should be noted that a transdisicplinary team, as is actually meant here, will not automatically solve issues of diverging or conflicting views. For that purpose methods for conflict resolution, consensus building and creating common ground need to be used, see for instance Scholz and Tietje (2002) and HarmoniCOP (2005).

In developing regional narratives as a basis for the qualitative systems analysis (QSA) the case studies show similarities and differences. All analyses of the cases have been based on official regional policy documents. Lombardy, Antalya and Pardubice conducted expert meetings with regional officers either through regular involvement (Pardubice) or by means of single meetings. Limburg, instead conducted a few meetings to inform regional decision-makers of progress made. All case studies conducted multiple cross-checks against various lists of sustainable development characteristics (e.g. EU Sustainable Development Indicators, Blue Plan, and Millennium Goals) to check if all necessary elements were included in the analysis. These checks were meant to ensure that all case studies used a similar analytical framework, albeit the regional analyses differed.

The regional narratives were translated into system maps to visualize the relations between the system-elements. (fig. 7.3) 


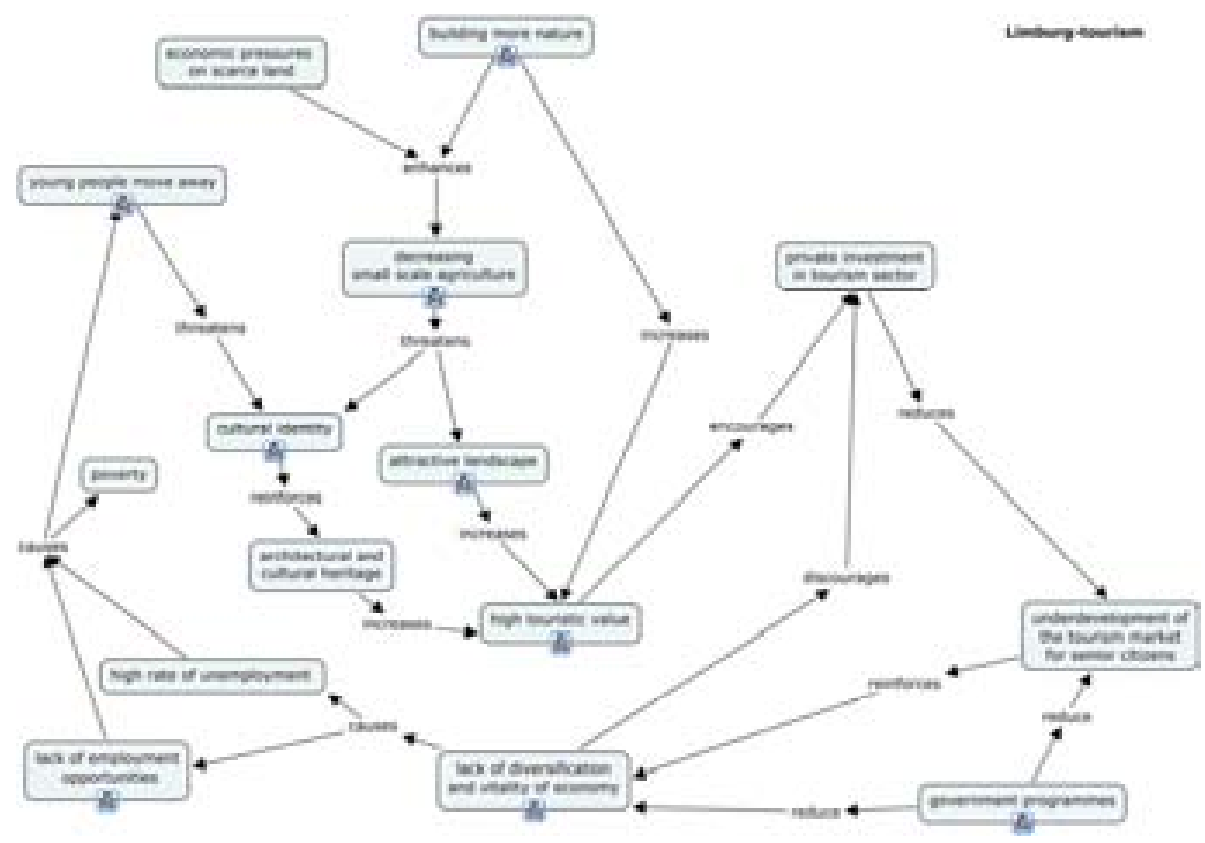

Figure 7.3: System map of Limburg: sub-system tourism

Each relation has been assigned a weight describing the intensity of the linkage between the elements. On the basis of these weights, every region prepared a sustainability spectrum that showed the upper and lower sustainability limits of the system, an average performance, as well as current performance. One of the results that is obtained is a sustainability spectrum (fig. 7.4 and 7.5) in which the actual performance of the region is defined per discourse, expressed in terms of a percentage ratio in respect to its sustainability potential (see (Caratti and Ferraguto, 2008; Jiliberto Herrera, 2008)). Other scholars have worked with similar concepts, such as the solution spaces for decision-making ((Wiek and Binder, 2005) and the sustainability choice space (Potschin and Haines-Young, 2008).

The sustainability spectrum for each region is the basis for comparability. Each axis represents one of the discourses in the region. However, the axes of the various spectrums can be different as they are based on the discourses that are specific to each region. Instead of comparing the spectrums with each other, we compare the situation of each region set against the regional potential. The situation for Limburg is shown (fig 7.4, table 7.3). 


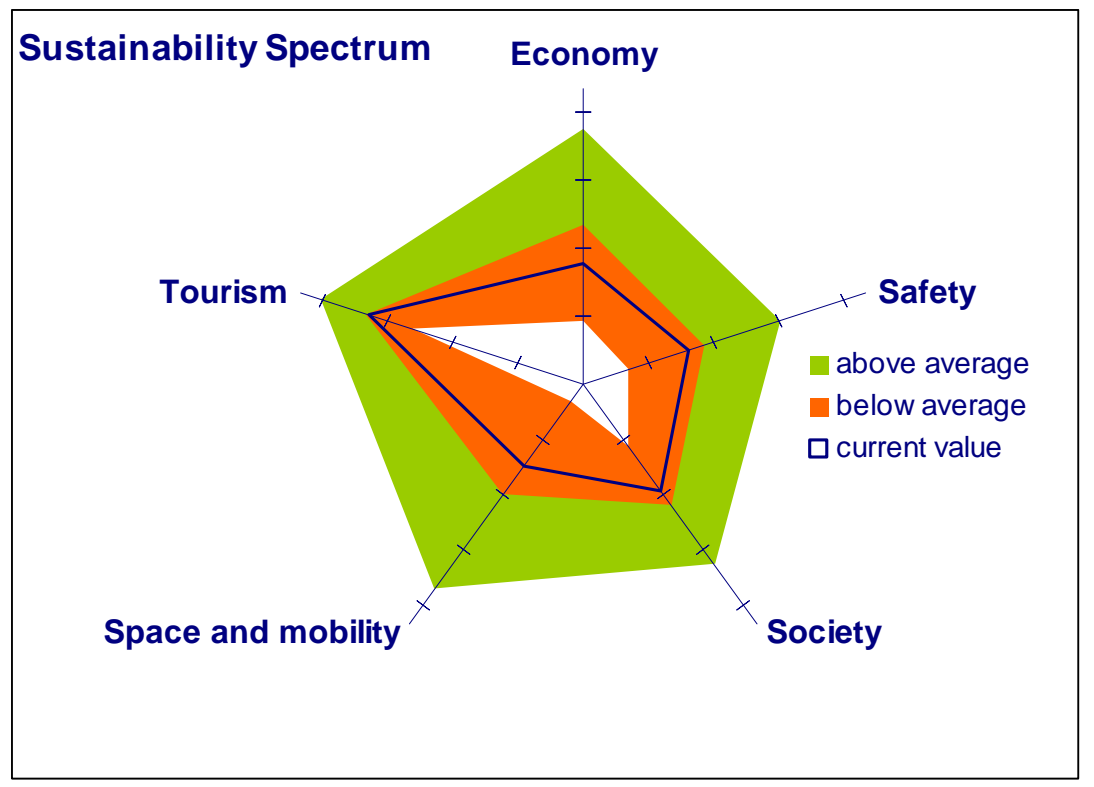

Figure 7.4: Sustainability spectrum Limburg

Table 7.3: The Limburg sustainability situation compared to potential

\begin{tabular}{ll}
\hline Sub-system & Progress towards optimum situation (\%) \\
\hline Economy & 30 \\
Safety & 40 \\
Society & 38 \\
Space and mobility & 34 \\
Tourism & 48 \\
\hline Average & 38 \\
\hline
\end{tabular}

Similarly, we can see the situation for Lombardy (fig 7.5; table 7.4). From these results we can conclude that Limburg and Lombardy are doing on an average quite similarly with respect to achieving their own regional potential. 


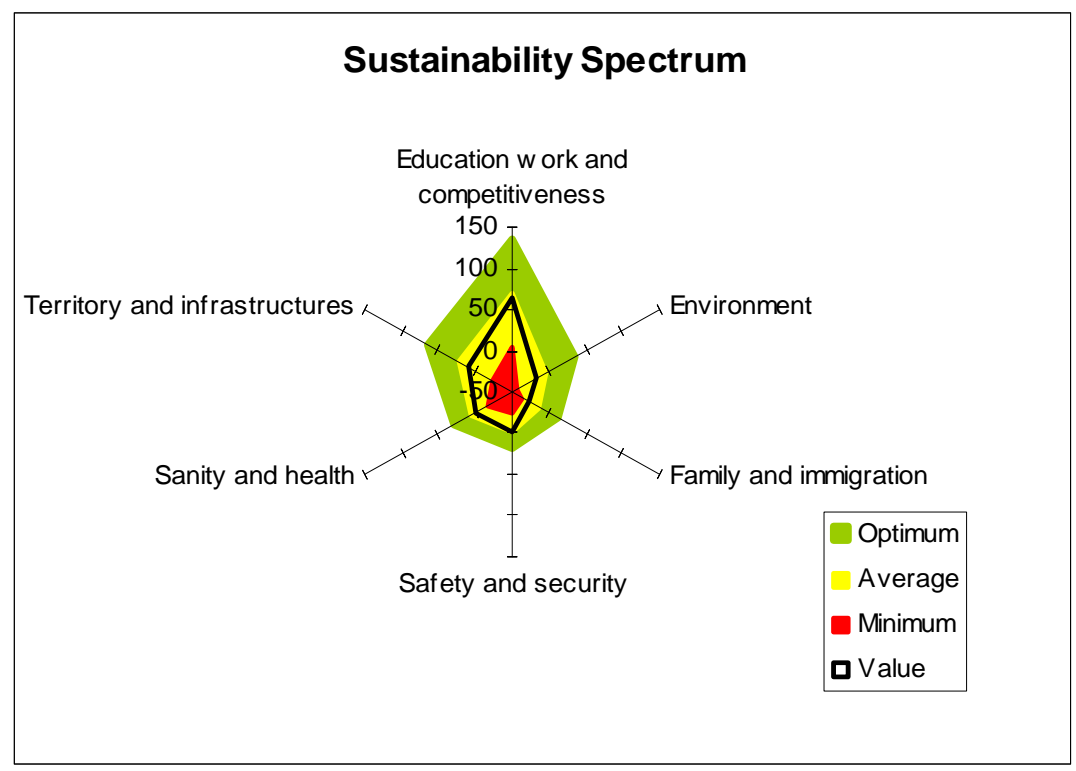

Figure 7.5: Sustainability spectrum Lombardy

Table 7.4: The Lombardy sustainability situation compared to potential

\begin{tabular}{ll}
\hline Sub-system & Progress towards optimum situation (\%) \\
\hline Education, work and competitiveness & 45 \\
Environment & 33 \\
Family and immigration & 19 \\
Safety and security & 52 \\
Sanity and health & 36 \\
Territory and infrastructures & 39 \\
\hline Average & 37 \\
\hline
\end{tabular}

The qualitative system analysis carried out in the system mapping is unique for every region. However, the method used was similar, i.e. they used weights for the relations and elements, a similar way of describing the relations between elements, and a thematic checklist as well as a check against the EU indicator framework for sustainability. When we compare the results of the S-mapping we compare the situation of each region (set against the regional potential). We are not able to say that any region is doing better or worse than another one, but we can say that one region is closer to its potential than another. In terms of Martinez-Alier et al. (1998) we could name this weak comparability. 


\subsubsection{System model}

The system model aims to provide a consistent picture of future regional development of European regions It is a system-dynamic model that provides quantitative indicators to measure and describe regional sustainable development considering the complex interactions within a single region and between the region and its environment. (Caratti et al., 2005) The choice for a system-dynamic model lies within the distinctive features of this typology of models, which specifically permit to provide an interdisciplinary focus on the observed systems, coupled with the ability to provide long-term trends. (Boulanger and Bréchet, 2005) The model uses a "Drivers-Pressure-State-Impact-Response" (DPSIR) structure to frame the most relevant dimensions that measure progress on the way towards regional sustainability.

"The INSURE model integrates two modules driving the development of regions, population and economy, with six further modules for infrastructures, spatial dynamics, energy, water, transport and environment. The basic idea of the modelling approach is to provide a structural framework of equations that is equal for any region implemented in the model, and differentiate the regions by varying the parameterisation. (fig. 7.6). To simplify transfer from one region to the other the parameterization should largely be based on databases that are available for all European regions. In particular, the EUROSTAT regio database is used to establish the input data for the model parameters." (Schade et al., 2006) The model itself describes always only one European region, but it is transferable to other European regions when input data-sets are changed. The model is an integrated one where regional aspects like population trends, economic development, water usage, energy demand, transport and spatial development are interacting to consider the feedbacks between the various aspects ${ }^{22}$.

Data collection and model calibration and validation have been developed by single case studies, based on data tables coming from various sources. In fact, the model is flexible enough to allow users to feed it, despite constraints in data availability for regions. Limburg and Lombardy have been covered through the Eurostat database. On the other hand Pardubice, which experienced lack of data available for their territorial level, assumed national data converted into the right format. It should be noted that in the application of the system model, the Antalya region has been replaced by the region of Cantabria in Spain due to data availability problems. Figure 7.6 shows the type of results obtained from the model: fully comparable future trends for a variety of parameters allowing us to compare how regions are developing in similar or different ways.

\footnotetext{
${ }^{22}$ For more detailed information see Caratti and Ferraguto, 2008; Caratti et al., 2005; and Schade et al., 2006.
} 

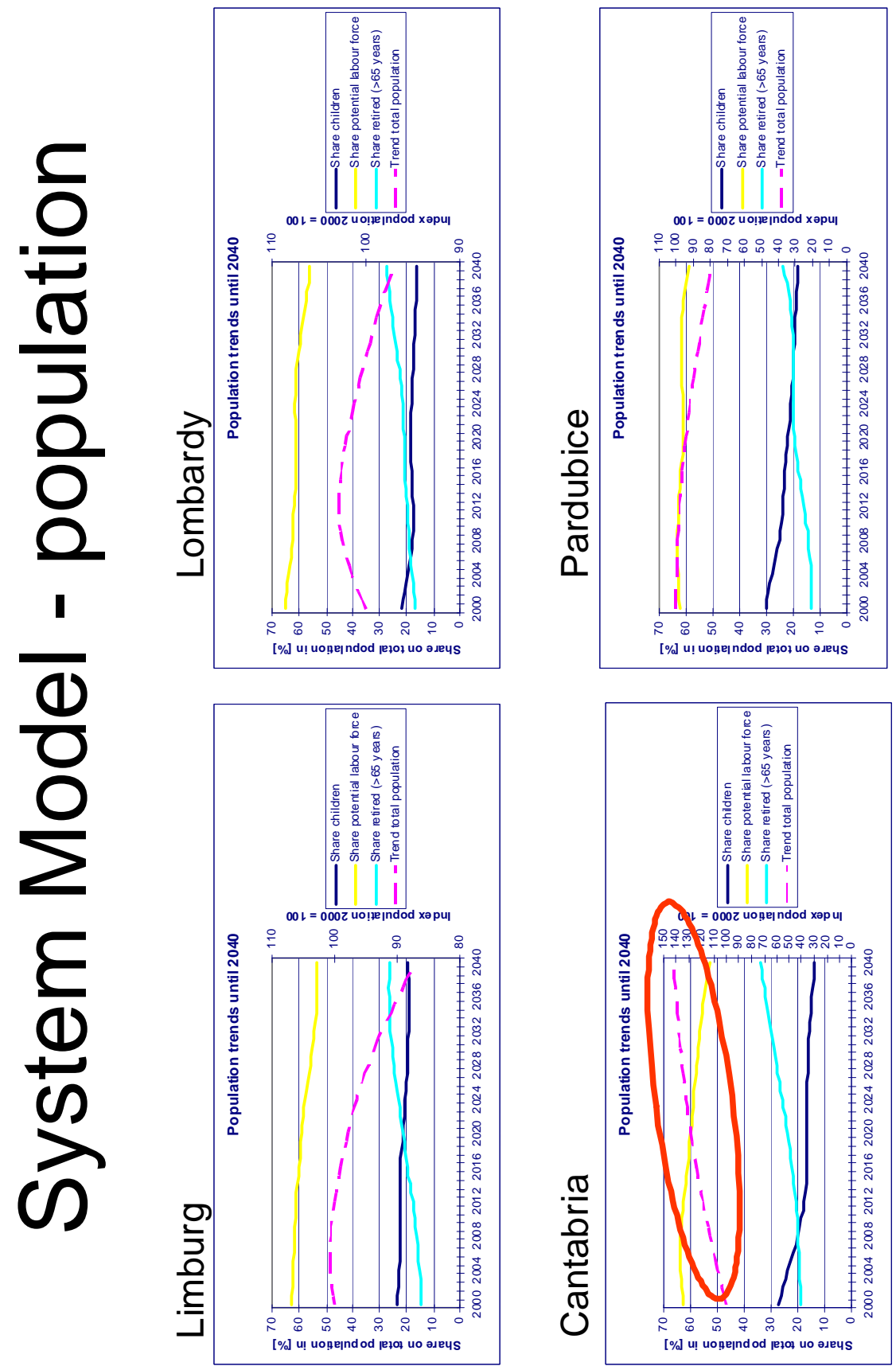

Figure 7.6: Model results for the population prognosis 2000-2040. The dotted line shows the trend for the total population in Limburg, Lombardy, Pardubice and an additional case study in Spain. The oval points at the divergent trend in Spain (INSURE, 2007a) 
Regarding population, the trends forecasted by the model as we see in fig. 7.6, witness that population in three of the regions decreases over time, while the Spanish region sees an increase due to the migration from surrounding areas.

We can consider on a general level that " ( . . ) the INSURE system model forms a platform for comparability and benchmarking between European regions. Since, from one side, the model provides a common structure for EU regional systems and, from the other side, it ensures that regional specific characteristics are well represented in such a scheme, it constitutes a flexible framework to monitor progress towards sustainable development at regional scale.". (Schade et al., 2006) In the case of the system model, direct comparability is possible. However, this tool has turned out to be quite complex to use and we have to consider that data availability and quality for the regional level are not always similar. In terms of Martinez-Alier et al (1998), this falls in the category of strong comparability.

\subsubsection{System indicators}

The system indicators tool integrates the two previous tools. With the help of a certain (normative) vision on sustainable development, that is reflected by an indicator framework (e.g. the EU-SDI framework) the available information from the mapping or the quantitative model is assessed. Concretely, the System Indicators tool develops an 'indicator filter' which selects from the previous models the most relevant elements for regional development, and systematizes them under a list of defined policy priorities hierarchically organized. (Zeijl-Rozema van and Martens, 2010) (Fig. 6.2, chapter 6)

These elements are qualified by proxy indicators, chosen through a participatory process among those indicators which are perceived as the most representative in that region, whose trends (parameterized in a qualitative +/- 2 scale) determine how the element behaves towards a sustainability policy target (e.g. a PM10 concentration trend might be used to determine how urban air quality is developing with respect to the policy target as defined in the policy framework). Once qualified, these elements are weighted according to the influence calculated in the QSA (Alvarez-Arenas and Miron, 2006; Jiliberto Herrera, 2008) and aggregated into an index of regional sustainable development deployed into priority sub-themes and themes.

The indicator system allows to understand how single components of regional sustainable development influence the behaviour of the overall system in relation to the policy priorities identified. (Alvarez-Arenas and Miron, 2006; Caratti and Ferraguto, 2008)

In order to ensure regional comparability, all case studies have used the EU Sustainable Development Indicator framework as an analytical framework. Each case study had to define the most appropriate elements from the System Mapping, based on two criteria: best fitting to a theme within the framework, and most in- 
fluential in the system. For those elements, proxy indicators were identified. This approach allowed for a common analytical framework as well as a consideration of regional specificities and results in a dashboard representation. (Alvarez-Arenas and Miron, 2006) (Fig. 7.7)
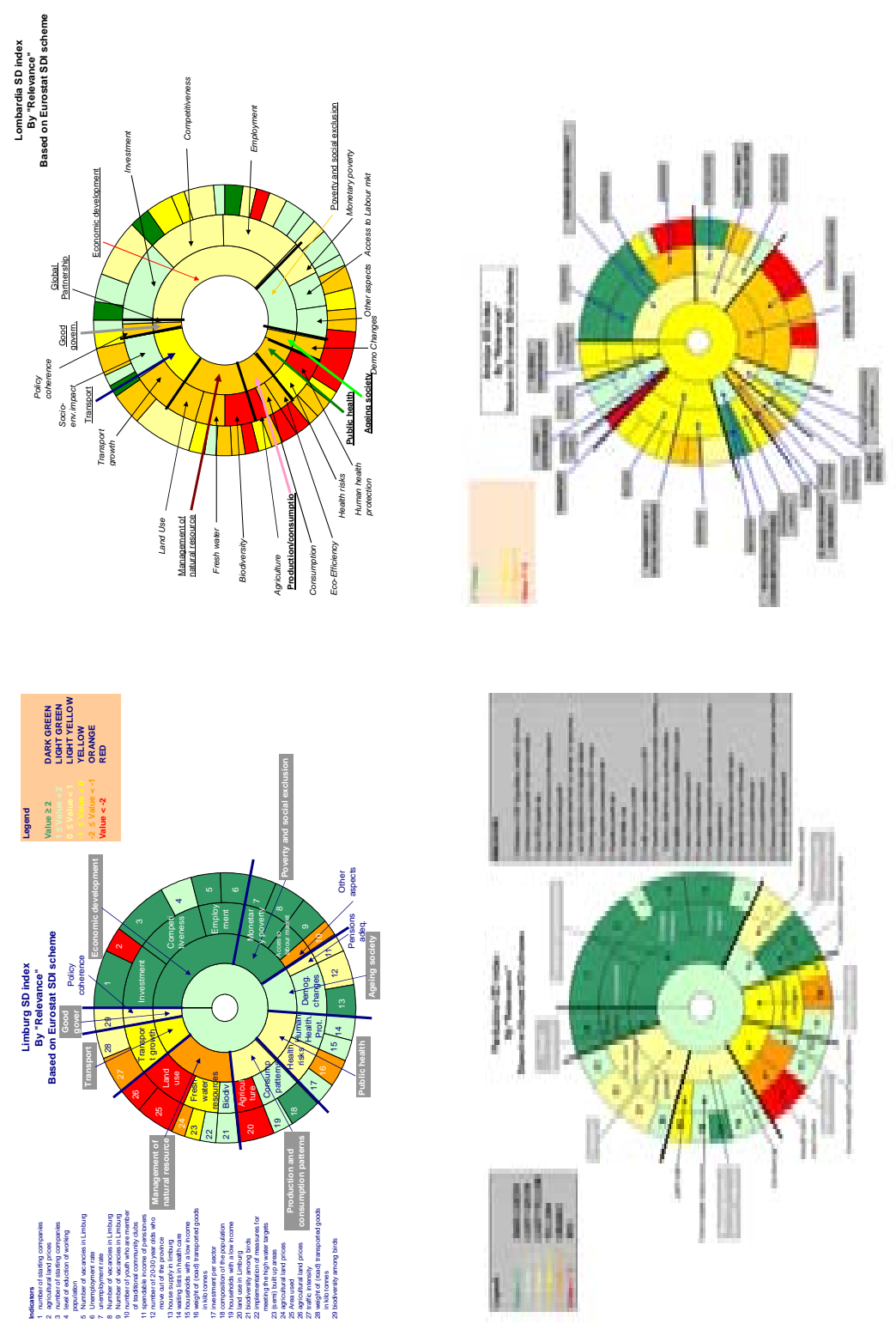

Figure 7.7: An impression of the visual representation of the system indicators for the four case studies (INSURE, 2007a) 
It should be noted that even though the regions were using the same framework, some themes and sub-themes were not relevant in all regions and were not represented. The following sub-themes are present in all case studies:

Investment, Competitiveness, Employment, Monetary poverty, Demographic changes, Human health protection and lifestyles, Biodiversity, Land use, Transport growth, Policy coherence

20 others are not present in all case studies. Furthermore, we should note that similar themes and sub-themes were represented by different elements and indicators in each region. This is illustrated for investment (table 7.5).

Table 7.5: The theme "investment" that occurs in all four case studies is represented by different entities in each region. For each entity, the corresponding indicator is in bold.

\begin{tabular}{|c|c|c|c|c|c|}
\hline Theme & & Antalya & Limburg & Lombardy & Pardubice \\
\hline \multirow[t]{5}{*}{ Investment } & Indicator & $\begin{array}{l}\text { Rapid regional } \\
\text { economic devel- } \\
\text { opment } \\
\text { Share of gross } \\
\text { domestic product }\end{array}$ & $\begin{array}{l}\text { Lack of diversifica- } \\
\text { tion of the econ- } \\
\text { omy } \\
\text { Number of start- } \\
\text { ing companies }\end{array}$ & $\begin{array}{l}\text { Investment in } \\
\text { human capital } \\
\text { Life long learning }\end{array}$ & $\begin{array}{l}\text { Lack of diversifica- } \\
\text { tion of the econ- } \\
\text { omy } \\
\text { Distribution of } \\
\text { GDP }\end{array}$ \\
\hline & Entity & $\begin{array}{l}\text { Public and private } \\
\text { investments }\end{array}$ & High land prices & $\begin{array}{l}\text { Research and } \\
\text { develop- } \\
\text { ment/innovation } \\
\text { technology }\end{array}$ & \\
\hline & Indicator & $\begin{array}{l}\text { Amount of public } \\
\text { investments per } \\
\text { capita }\end{array}$ & $\begin{array}{l}\text { Agricultural land } \\
\text { prices }\end{array}$ & $\begin{array}{l}\text { Total R\&D expen- } \\
\text { diture as \% of } \\
\text { total budget }\end{array}$ & \\
\hline & Entity & & & $\begin{array}{l}\text { Construction of } \\
\text { adequate trans- } \\
\text { port infrastruc- } \\
\text { tures }\end{array}$ & \\
\hline & Indicator & & & $\begin{array}{l}\text { Road develop- } \\
\text { ment index }\end{array}$ & \\
\hline
\end{tabular}

This is precisely what is unique about the INSURE method: it provides a flexible framework for indicators. Regions choose those indicators that for them represent best the element "investment". It would be much easier to decide on one generic indicator for all regions, but, as is demonstrated by the variety the regions come up with, regions prefer an indicator that fits their situation.

A further consideration regards the selection of indicators and data availability. In the INSURE case studies experience, it has been observed that well-known international lists of indicators (e.g., Blue Plan, EU-SDI, Millennium Goals, and ICSIMM Mediterranean) did hardly contain appropriate indicators for the regions. (Caratti et al., 2006) And this means that comparability on an indicator-by-indicator basis is neither possible nor desirable. 
Furthermore, the adoption of the EU framework does not always allow for inclusion of regional priorities. This has been evident in the cases of Pardubice and of Limburg: in both cases a number of high ranking elements from the QSA could not be linked to any theme in the EU framework.

The resulting dashboards give an indication on how trends are developing and on which ones are problematic. Figure 7.7 shows a variety of themes that depict the sustainability performance of the region. We see Limburg and Pardubice with a similar end result (inner ring of the dashboard), whereas Lombardy and Antalya are slightly worse off. Although Limburg and Pardubice have similar end results, the outer rings show different areas that need attention from policy.

Another finding is that where similar indicators were used, data collection methods might not be the same. So, no comparison at the single indicator level is possible. Instead, the approach developed through the System Indicators framework allows the data trends obtained from indicators to be converted into sustainable development trend values, which are not determined by statistical data only, but are also weighted depending on how they are expected to influence other sustainable development trends in the region.

In conclusion, this tool provides for each case study the same framework of analysis, a similar way of assigning weights but region-specific elements and regionspecific indicators for the four case studies. Based on these issues, this would be a case of weak comparability as described in Martinez-Alier et al. (1998).

\subsubsection{Integrated findings}

Each case study produced a regional sustainability assessment based on the application of the three tools. These assessments have been extensively reported in the INSURE reports and will not be reproduced here.

(See http://www.icis.unimaas.info/wp-content/uploads/2010/05/INSURE-casestudies.zip) What is interesting is to look for any specifics or commonalities through a comparison of the results. If we can derive information that is common for most case studies we have identified issues that can be dealt with at an overarching policy level. However, some issues are special for one region, due to its history, its population dynamics, its emphasis on one economic activity, etc. Those are issues that cannot be dealt with by means of a 'blanket' approach but need special attention.

\section{Commonalities}

In all of the case study regions we see positive economic developments, ${ }^{23}$ but this sometimes negatively affects other sectors (Lombardy: land degradation, and Lim-

\footnotetext{
${ }^{23}$ It should be noted that all analyses were completed in 2007 , i.e. before the start of the current worldwide economic crisis
} 
burg: space scarcity). Demography is an important factor as well but issues are diverse. Antalya has problems with urbanization and a high growth rate whereas the other three face the issue of an ageing society. In Lombardy the ageing society is seen as a problem, in Limburg and Pardubice less so. Both Antalya and Pardubice show a move from rural areas to the cities. Transport is characterized in Limburg and Lombardy by congestion problems. Pardubice suffers from a general deficiency in infrastructure.

\section{Specifics}

Specific to Pardubice are the environmental problems as a legacy of the Communist regime. Antalya shows specific problems of rapid urbanization, leading to unbalanced development. Limburg suffers from lack of space, which is common for the Netherlands, but emphasized by Limburg's narrow shape. Lombardy specifically points at R\&D as an important engine for sustainable development, and sees failing policy implementation as affecting sustainable development. Also safety and security issues seem more prominent here than in other regions.

This leads us to conclude that there are common issues among regions and specific issues, which need different ways of approaching regional sustainable development. It might however be useful to explore the commonalities among European regions and develop a set of indicators to create a stronger basis for comparison.

\subsection{Discussion}

Although we have made an effort to compare results of a flexible framework, we cannot ignore some challenges that are summarised in table 7.6.

The system mapping is obviously not the most sophisticated way in which to build a cognitive map and identify the most important elements within the system. One major deficiency, which was covered by recent applications of qualitative tools, is the ability to systematically define clusters or patterns, which eventually provide more detailed information about the variables of the system under examination (e.g. Nuissl et al., 2009; Wiek et al., 2008). However, system mapping as conducted in the four case studies, represents indeed a way which has proven to be workable and simple enough to be used by stakeholders. A matter of discussion is always where to place the boundaries of the system and how to deal with external influences. One may think of a rural region that is heavily dependent of a neighbouring city region. These influences cannot of course be ignored and should be included in the regional analysis, if only as an external factor influencing the system. Depending on the weight assigned by stakeholders, this external factor will be more or less important in driving the system. For comparability purposes, we have said that we compare the region's performance related to its regional potential. The danger 
exists that some regions will have set lower potentials than others and thus might have a false sense of achievement. It would seem that in addition to the spectrum a set of standard indicators might be measured that puts the region in its wider context.

Table 7.6: Comparison challenges

\begin{tabular}{|c|c|c|c|}
\hline Main Features & System Mapping & System Model & System Indicators \\
\hline $\begin{array}{l}\text { Comparability be- } \\
\text { tween regions }\end{array}$ & $\begin{array}{l}\text { A similar way of con- } \\
\text { structing the QSA and } \\
\text { sustainability spectrum. } \\
\text { Discourses are region- } \\
\text { specific. }\end{array}$ & $\begin{array}{l}\text { The same model is } \\
\text { applied and the same } \\
\text { output indicators are } \\
\text { obtained. Region-specific } \\
\text { data-sets and parame- } \\
\text { ters are used. }\end{array}$ & $\begin{array}{l}\text { In this chapter, for compara- } \\
\text { bility reasons the same policy } \\
\text { framework was used (EU- } \\
\text { SDI). Indicators are region- } \\
\text { specific. }\end{array}$ \\
\hline $\begin{array}{l}\text { Type of comparabil- } \\
\text { ity }\end{array}$ & Weak. & Strong. & Weak. \\
\hline $\begin{array}{l}\text { Type of interregional } \\
\text { knowledge }\end{array}$ & $\begin{array}{l}\text { How far is each region } \\
\text { away from its potential. }\end{array}$ & $\begin{array}{l}\text { What is the develop- } \\
\text { ment of specific indica- } \\
\text { tors for each region. }\end{array}$ & $\begin{array}{l}\text { Which of the EU policy fields } \\
\text { are of importance in each } \\
\text { region. Are there issues that } \\
\text { are important for all regions } \\
\text { and how is the performance } \\
\text { of such common issues } \\
\text { across the regions. }\end{array}$ \\
\hline Problems & $\begin{array}{l}\text { If a region is rather } \\
\text { pleased with its per- } \\
\text { formance but its stan- } \\
\text { dards are lower than } \\
\text { other regions' there } \\
\text { might be a false sense of } \\
\text { achievement. }\end{array}$ & $\begin{array}{l}\text { If data are not available, } \\
\text { there will be no model } \\
\text { results. }\end{array}$ & $\begin{array}{l}\text { Regions do not use the same } \\
\text { indicators for the same } \\
\text { theme, and data is not } \\
\text { uniformly collected. Precise } \\
\text { comparability is lacking. }\end{array}$ \\
\hline
\end{tabular}

In the case of conflicting or diverging views on the system to be described the system mapping could be used as a tool to explore these different views. In the four case studies this situation was not encountered, but we could imagine that some methods for conflict resolution, consensus building and creating common ground need to be used (cf. HarmoniCOP, 2005; Scholz and Tietje, 2002). Conflicts could exist on the importance of certain elements and relations between them, or on their contribution to sustainable development, or on what exactly sustainability is. Different calculations with different weights could be made to indicate which indicators would be more important in one view and which in another. A compromise might then be found in extending the list of indicators to include concerns from all parties. This would also imply different end results in the dashboard: in one perspective certain elements are more important and will influence the outcome more than in another perspective which might have consequences for the overall sustainability outlook of the system. 
However, in this chapter we worked with the EU framework to provide common ground in the vision on sustainability, even although it is not meant for the regional level, and also created comparability in which elements contribute to sustainability and damage it.

The system model results in parameters, but in order to understand what they mean for sustainability they need to be interpreted within the qualitative system analysis and indicator framework. A weak point is that data availability at regional level is not always guaranteed and in that case no outputs will be obtained, as we experienced in the case of Turkey, given the complexity of the calculations implied within the model.

In this sense, the application of semi-quantitative modelling techniques such as Cross-Impact Analysis (Weimer-Jehle, 2006) and Sensitivity Model Tools (Huang et al., 2009), which require a less extensive knowledge of the systemic variables, would provide scenarios of systemic development without having recourse to wide datasets. These tools can provide a useful alternative for a systemic analysis relying on an internally consistent system, and would be furthermore based on expert or stakeholders judgement about internal influence and relations between variables.

The system indicator tool is a strong visual tool that shows how indicators have an impact on regional sustainability outcomes and how they relate to each other. However, even for common themes in the case studies, diverse indicators were used. This is because many indicators were not present in Europe-wide databases of regional information. However, it would be helpful if similar indicators for common themes could be used if this method is carried out for comparing regions at the national or European scale. We recommend that further research be conducted in regions and the common themes identified, and indicators for those found. This set should be complemented by a whole set of region-specific indicators to be chosen by the regions themselves. It should be noted that in the case of comparison, an identical framework is always needed.

Another topic that deserves attention is that of thresholds. An indicator in itself is meaningless. Criteria and thresholds give meaning to an indicator. These criteria are, like the choice for a certain indicator framework, normative choices, even if they are based on scientific findings. For instance, if a certain concentration of a chemical means that $1 / 10000$ people will develop cancer, we make a choice if that is acceptable or not. In many cases thresholds are very hard to define. Consider for instance, the indicator "inflation rate": when is it acceptable? It would be impossible to define, since in some cases inflation may be considered as a positive phenomenon and in others as negative!

INSURE assessments cannot be reduced to a simple "alarm function" that indicates that some indicators have trespassed a given limit. INSURE assessments have a fundamental role in understanding which are the most important things to keep 
under control in a regional system that can exert an influence on others. The final aim of a sustainability assessment is to help policy makers in deciding about resources' allocation towards different aspects and dimensions of sustainability. We cannot consider this assessment taking place at a sort of "zero point", on which any further policy depends. Instead, we face situations where certain policies are already implemented and which need to be monitored and assessed as they go. An INSURE assessment may of course complement less integrated and more simple indicator systems, which give a one-dimension information in terms of progress towards or distance from a given threshold.

It is to be concluded that the main aim of the INSURE toolkit is not to provide separate tools for analysis, but to create complementary analytical frameworks, each giving a different perspective of the reality under examination. The integration between a very flexible instrument like S-Mapping with S-Indicators aims at mutually reinforcing a soft systemic representation of regional dynamics with a list of policy targets, trying to highlight local specificities; on the contrary, mathematical modelling, such as System Dynamics, permits to identify common problems in details, forecasting trends and future scenarios. In our opinion, this might respond to the challenge of integrating qualitative and quantitative tools, which represents an ambitious option in sustainability analysis (Grosskurth, 2007).

\subsection{Conclusion}

We have seen in chapter 6 that integrated monitoring of sustainable development is possible in the region. In the integrated sustainability assessments we have information on the current state of the region, its potential and the type of problems the system faces (S-mapping), prospective trends (S-model), retrospective trends and an indication of the thematic issues that are problematic (S-indicators). This chapter investigated what happens if the regional results need to be compared with other regions. Can regional flexibility be maintained?

For each region in this chapter a unique assessment of sustainable development is available. However, although the results are unique, the methodology is shared by all case studies. We saw that we cannot compare the assessments theme by theme. We can however compare which trends or themes are important in each region and which problems occur. Therefore, we feel that both at the regional and at the EU level, decision-makers can derive useful information. At the regional level they will be pointed towards the most problematic issues, while at the EU level common problems when dealing with sustainable development will become clear. 
As Martinez-Alier et al. (1998) state, comparability is more than strong comparability only. Especially in the case of sustainable development the many variables cannot be compared and an assessment that tries to make them comparable by using one type of value (e.g. monetary value) only is a misleading basis for decisions. The INSURE method combines various types of comparability. Weak comparability can be found in the cases of the system mapping and system indicators. In the first one we compare the regions' performances with their own potential, while in the latter we compare commonalities and difference. Strong comparability can be found in the system model that provides the same prospective indicators for each region. The resulting regional sustainability assessments, will not be exclusively based on a top-down definition of sustainability, fed by national-level data which cannot easily be applied to regional realities (Graymore et al., 2008), but instead will be devised with a greater degree of flexibility.

In conclusion, comparability of sustainable development between different regions is not an issue of rigid comparison of indicator by indicator. It should take into account regional specifics. The resulting shift from strong to weak comparability should not be seen as a lessening of the quality of the assessment and decreasing comparability. Rather than focusing on individual indicators within frameworks that do not permit inclusion of regional developments, this allows us to look at the broader picture of regional dynamics. It reveals specific regional weaknesses that need attention, and possible areas for building alliances between regions, thus creating a more sustainable Europe.

Still, it seems that maintaining flexibility for regional characteristics and ensuring interregional comparability do not match easily. Because we recognise the need for strong comparability we propose to define a small core set of regional indicators to improve comparability, to be complemented by region-specific indicators that allow for commensurability if the same method and framework is used. Specific problems might then be linked to regional characteristics (rural, tourism-based, industrial, etc) which will provide valuable insights for adjusting overall EU sustainable development policy objectives to those regional characteristics. 



\section{Conclusion, recommendations and reflection}

Although strategies, policies, and projects on sustainable development exist, it is still problematic to implement sustainability. This is shown by a lack of systematic and full-scale action. That is why this thesis investigated:

What are the barriers to implementation ${ }^{24}$ of sustainable development in current practices in Limburg, taking into account different perspectives on sustainable development and different modes of governance; and how can these barriers be overcome?

Related sub-questions that are addressed in this thesis are:

1. What role do different perspectives on sustainable development and different modes of governance play in current sustainable development policies and practices?

2. What barriers to implementing sustainable development exist in sustainable development strategies (SDS)?

3. What barriers exist in the current understanding of, and action towards, sustainable development of the Limburg population?

4. What barriers to implementing sustainable development exist in current sustainable development projects in Limburg, and what role do the different modes of governance play?

5. How can sustainable development be monitored in an integrated way, and what barriers occur?

In seven chapters theoretical and empirical analyses were conducted to find answers. The barriers were investigated through a study of different practices: policy, citizens' understanding and actions, practitioners experiences with sustainable development, and integrated monitoring. In these past chapters we have seen that sustainable development is inherently a normative concept that needs to take the interrelatedness of the domains of ecology, economy, and society into account, and also today's impacts as well as future consequences, and impacts here and elsewhere. How exactly sustainable development is defined, is a normative and societal choice. That means different visions of a sustainable society are possible, not only between places, but also for the same place over time. As insights change, and as external influences change, also society's ideas about sustainability might change. However, because of its integrated nature and related to that, its complexity, and because of the lack of urgency in society, achieving sustainable development will require societal steering. Steering should not anymore be seen as a hier-

\footnotetext{
${ }^{24}$ Implementation in this thesis refers to operationalisation and implementation of policy and plans on sustainable development
} 
archical form where one actor, often government, decides what is to be done, by whom and within which time period. Societal steering, or governance, has become an issue of many actors, with a variety of instruments to be used, multiple processes to be managed and institutions that have to find a new role in coordinating, facilitating and enabling all of this. Steering in this sense can be done in a more hierarchical or a more deliberative way, and a different approach will lead to different trajectories towards implementing sustainable development.

Often we see in government institutions and educational centres a bias towards sectoral and disciplinary approaches. However, in sustainable development, integration is the key word. Working in the field of sustainable development requires that we see the world as a system. This is a relatively new approach that does not make disciplinary work superfluous, but requires a different way of handling knowledge and the presence of certain integrative skills.

Science for sustainable development aims explicitly to help sustainable development forward. Therefore, it is important for science to ensure policy relevance. A question that has always guided this thesis is one from government staff, who wanted practical guidance on what they could do with the scientific knowledge that was produced. Throughout this thesis policy relevance is ensured with the help of this question.

The following sections will discuss the barriers to implementing sustainable development, and the impact of different modes of governance and perspectives on sustainable development on these barriers. Some possible solutions to overcoming the barriers are given and finally, some of the numerous challenges will be discussed. These barriers have been grouped into three broad categories. The first deals with understanding sustainable development by means of a vision, goals and policy. This category is about getting a hold on the concept and making it manageable. The second category is about the necessary conditions and structures for implementing sustainable development, which can be called the enabling environment. The third category deals with the capacity among the people to absorb sustainable development and act on it. This is referred to as the sustainable development consciousness. This categorisation should not be seen as a linear sequence of barriers. The barriers are interrelated and dependent on each other.

\subsection{What barriers occur in current practices?}

\subsubsection{Understanding sustainable development: complexity, vision, goals and policy}

Sustainable development is a complex process that requires an integrated approach. This in itself is a barrier to implementation. However, complexity can be made manageable. For sustainable development this would require a vision of the 
desired future and linked to that vision, goals to be achieved. However, as we saw in chapters 3, 4, 5 and 6, precisely a vision and goals are often lacking in policies at various levels, although stakeholders see it as important at all levels and for all stakeholders to have a vision and goals. Furthermore, dealing with complexity can be done by breaking up a complex issue into smaller areas for taking action. This is done, but results are not merged to see progress towards the desired future. Essential is that during the process of implementation the results of the actions are evaluated against goals and vision to see what progress has been made towards achieving the vision.

The integrated approach that is needed for sustainable development should be reflected in policies on sustainable development. However, although sustainable development policy exists at EU, national and regional level, and propagates integratedness, sustainable development policy, as it exists now is confined to environmental departments and has its own niche, i.e. it is not present everywhere. Icon projects and proposed actions operate within this niche and policymakers seem to forget that sustainable development is something that needs to happen everywhere. Also, sustainable development policies at the different scale levels EU, national, regional - are not linked. Sustainable development is a transboundary process which means that an isolated effort that is not well connected is simply not enough.

\subsubsection{Enabling environment}

What is currently missing in the Province of Limburg is an enabling environment that will help to implement sustainable development. An enabling environment helps, instead of obstructs, sustainable development by providing vision and coordination where necessary. Such an environment would encourage action, connect people, and provide structure as well as space for innovation. Currently there are internal tensions in the provincial government actively obstructing sustainable development. Furthermore, in chapter 5 we saw that people with capacities for process management of sustainable development are needed, who are currently not available. Another problematic issue is that of roles. It is currently not clear which stakeholder will play which role. It is important to distinguish between the different roles of stakeholders, for instance in the process of monitoring. Experts/scientists and policy makers often have different but complementary roles to play.

The last issue is related to who should take the lead. Currently citizens want government to take the lead and government is waiting for citizens and the market to take action. This impasse needs to be breached. 


\subsubsection{Sustainable development-consciousness}

We saw in chapter 4 that currently environmental consciousness is mainstream, but sustainable development consciousness is not. The survey results showed that if people are aware of sustainable development, they behave more sustainable. It was observed that people are not aware of what sustainable development means concretely and what actions they can take. This explains why they are not acting sustainable development conscious. An important barrier towards acting more sustainable is thus the lack of knowledge about concrete actions that people can take, which could be remedied by an information campaign. However, many people also say that they are only willing to take action if the individual benefits are clear. In other words, they are asking for incentives for becoming more sustainable. At the same time, people indicated they want to change in an easy way. As benefits of behaving in a sustainable way are likely to have returns only in the long term and probably at the collective rather than the individual level, an information campaign only will not result in more sustainable action. But there is another side to the request for incentives. Although many people understand that sustainable development is about a balance between the environmental, social and economic domain, at a concrete level economy was mentioned very little as playing a role in sustainable development. This means that when people were asked about concrete examples of sustainable development, economic issues were not mentioned. People's actions, however, are mainly driven by economic considerations (what is the cost) and quality. If economic prosperity is not seen as an integral part of sustainable development, the lack of motivation and urgency to work on sustainable development can be better understood. However, as long as many costs are not internalised in prices, it will be difficult to change behaviour.

What is important to note in the field of an information or awareness campaign is that different groups in society have different understandings and behaviour towards sustainable development. This means that a blanket approach will not work.

\subsection{Different perspectives on sustainable development, and different modes of governance, and the role they play in the barriers encountered}

In chapter 2 a framework was designed that coupled different modes of governance with perspectives on sustainable development. It is important to realise that different modes of governance exist, ranging from deliberative to hierarchical, and different perspectives on sustainable development, ranging from ecological to wellbeing. Depending on the perspective used and the mode of governance, different constellations of processes, instruments, actors and institutions will play a role in sustainable development. Tensions can arise if certain tools or procedures do not match. 


\subsubsection{Perspective on sustainable development}

The different perspectives on sustainable development were expected to have an impact on the goal definition, and the role of science and society. However, in chapters 3 and 5 we saw that although sustainable development is presented as well-being or quality of life it is often at a practical level interpreted as environmental protection. We did not see evidence of science playing a prominent role in defining sustainable development, as suggested in the ecological perspective, or of the notion that there are objective and measurable boundaries. Nor did we see evidence of strong societal involvement in goal definition at regional or national level as was expected in the well-being perspective. The only evidence of this was the broad societal review process of the EU sustainable development strategy (EU SDS). What we see is a rather indistinct way of thinking about sustainable development. This does not help implementation. It seems that the full concept of sustainable development with its integratedness and temporal and spatial implications has not yet landed. Because sustainable development is presented as well-being, but is implemented as environmental protection an inconsistent perspective on sustainable development is the result. For a topic that is so complex already, and that is surrounded by debate, obviously such an inconsistency only increases vagueness.

\subsubsection{Mode of governance}

The different modes of governance were also expected to have their impact, especially on who takes decisions and on relations between actors and management. At the national and regional level we saw examples of a more hierarchical type of governance, where consultation with stakeholders on goals and pathways was absent. At the EU level stakeholders were asked to participate in the review process, and more review processes are foreseen in order to allow for changes in perceptions and insights and thus in preferences for sustainable development. It should be understood that there is nothing wrong with a hierarchical mode of governance. However, it is propagated that for sustainable development to be a success everybody needs to participate. In the hierarchical governance this will happen if people are strongly motivated, for instance by a wish to follow their leaders. There is no sign at this moment of such a feeling. In chapter 5 it was mentioned that important people to get on board are champions (e.g. the local football hero, All Gore, a famous musician, a popular politician, etc), but there is no sign of this happening.

As for a comparison between hierarchical and deliberative modes of governance, chapter 5 showed a tension between the need for innovation and the need for fitting into existing structures and working with a clear organisational structure. In the province of Limburg with a hierarchical type of governance, especially the need for innovation with its consequences of a different type of organisation, are met 
with resistance by provincial staff. The need for structure was found to be hampering progress in the open innovation network of Greenport Venlo. So, in this research, examples of both types of governance showed some problems.

\subsubsection{Expressions of governance for sustainable development}

In chapter 2 "expressions of governance for sustainable development" were mentioned. These were important elements that are not specifically governance or specifically sustainable development, but go hand in hand with governance for sustainable development. These were expected to differ according to the governance-sustainable development type defined in the framework. The expressions of governance for sustainable development that were mentioned in chapter 2 were

- the implementation strategy and discretion for implementation;

- commitment;

- dealing with uncertainty;

- focus on goals or on processes;

- attention for technical fixes or behavioural change;

- implications for monitoring and evaluation (M\&E).

What we saw in chapter 3 was that the sustainable development policies at national and regional level were not consistent, meaning that within one policy we found "expressions" that were assigned to other types of governance for sustainable development (other quadrants of the framework). This can mean two things: the "expressions" were misplaced in the framework, or the policies were inconsistent. However, regardless of where the "expressions" should be in the framework, one inconsistency has already be mentioned above, namely the fact that policies describe sustainable development as well-being, but act as if it means environmental protection. Other noteworthy problematic areas in the sustainable development policies studied are that:

- the process of creating commitment to sustainable development is very unclear in the practices investigated. At present, there seems to be no systematic approach to creating commitment for realising sustainable development;

- the implementation strategy presented is sometimes clear on goals and implementation pathway, and sometimes not, within one and the same policy document. A clear reason for choosing different approaches is not given;

- uncertainty is not addressed to a large extent, although it is an important component of implementation of sustainable development;

- current monitoring requirements focus largely on achievement of results, rather than on processes, and are not described in detail. As we know, sustainable development is a process of becoming and results are expected to take time to appear. Therefore attention to processes would be useful. 


\subsection{Some recommendations on how the specified barriers can be overcome}

\subsubsection{Understanding sustainable development: complexity, vision, goals and policy}

The complex nature of sustainable development can be made manageable by addressing the problem of the lack of a vision of the desired future. In chapter 4 the citizens of Limburg indicated they needed a vision at all levels, ranging from local organisations to business and education towards government at local, regional, national and EU level. Right now there is often a general vision of a country or region and, sometimes separately, a sustainable development vision. It would be more useful to make a general vision of the desired future at each scale level that includes sustainable development as a guiding principle. The reason for this is that given the integratedness of the concept it makes little sense to confine it to its own niche with its own restricted vision. Nor does it make sense to make a sustainable development vision for the country or region, which is different from the general vision.

In the policies that were investigated a well-being understanding of sustainable development, was favoured. A true well-being approach includes an acknowledgement of a diversity of interests. This means a broad societal process is needed to make an inventory of the various ideas and to define common goals. It is also important to show conflicting situations and unsustainable situations. In other words, transparency on possible choices and reasons for choosing a certain pathway is needed. A way for dealing with the inevitable uncertainties due to lack of data and lack of understanding must be included in the process as well. Linkage with other scale levels should be actively sought, because sustainable development does not stop at regional or national borders. A mechanism for revising the vision and goals needs to be incorporated in implementation strategies. Changing insights and changing needs will require an adjusted vision. The checklist developed in chapter 3 could be used to check for consistency in the vision and for its sustainability potential.

The checklist is also useful for facilitating an integrated approach towards sustainable development. By ensuring an integrated approach and inclusion of sustainable development principles in the overall vision, the current situation of sustainable development in a niche will be remedied. However, until sustainable development is mainstream, specific attention in the form of policy, budget and staff remains vital.

Proper monitoring for assessing progress needs to be put in place, including guidance on monitoring requirements (what needs to be monitored) and monitoring time (when should it be done). Attention to processes needs to be given, in addition to reaching the goals, because this helps to show progress in the short term. Processes can be up and running before goals are being met. 
It is clear that such a movement as described above is large and requires the type of coordination that only government can provide.

\subsubsection{Enabling environment}

For successful implementation of sustainable development an enabling environment is needed. We have seen in chapter 3 and 5 that a mix of hierarchical and deliberative approaches is necessary. We have also seen in chapter 5 that structure is required, but also space for innovation. Instead of establishing new institutions, it seems more practical to define themes, processes and roles that are necessary and form groups around these. After each revision of the desired future and of pathways to achieve it, new roles and processes might become necessary, which means a flexible and adaptive structure is important. It is thought that a core institution such as the provincial administration is needed to serve as coordinator and facilitator, with the ability to connect different parties and with a responsibility in safeguarding monitoring. The advantage of not creating new institutions but rather working with open structures is that innovations will have more space. Process managers with the proper skills (see chapter 5) are of great importance. Therefore, in recruitment of new staff these skills need to be explicitly specified and tested.

To reduce tensions in existing government institutions, staff must be educated. Internal thematic round tables could be created for improved cooperation. Sustainable development should be treated as a balance of people, planet and profit and not as the current environmental focus. Staff should be presented with examples of what sustainable development means for "non-sustainable development topics" such as competitiveness of regional trade and industry, or culture. It is also important that staff understand the link of their work with the rest of the system. Qualitative system mapping could be a helpful tool. At all levels and for all departments a sustainable development checklist, such as the one developed in chapter

3, might be used and expanded.

Furthermore, we should not forget that an enabling environment is an environment of cooperation, in which different parties (government and others) take on their roles. Every player has different strengths and plays different roles. In chapter 4 we saw that the citizens of Limburg think government should take the lead; business and research stakeholders should take care of innovation and technology; educational institutions should provide information and society should form partnerships and take action.

\subsubsection{Sustainable development-consciousness}

In addition, an information campaign needs to be set up to make sustainable development mainstream in the same way as environmental protection has become mainstream over the past decades, and to take away current vagueness and confusion on sustainable development. We saw in chapter 4 that people who know what 
sustainable development means, score better in their sustainability behaviour. People asked for information on concrete actions and benefits. It is thought that information on benefits needs to be given for the short, mid and long term and for individuals as well as for society. Information needs to be differentiated according to age, gender and education. Companies of different sizes also require a different approach. Small companies need more detailed and concrete information than big organisations. Information must include concrete actions and examples. Products and services need to indicate environmental and social information. Mobility requires special attention.

However, if we look at the survey results for current behaviour, we see very few decisions being made on the basis of environmental or social criteria. Even the people who are aware of sustainable development take most decisions based on quality and costs. People also want "easy" change. Therefore, an information campaign should be combined with actions such as legislation, taxing, subsidising, visioning, creation of an adaptive governance structure, open organisation around themes and processes, and cooperation between stakeholders. Government's role is to coordinate, facilitate and monitor.

\subsection{Reflection}

The conceptual framework presented in chapter 2 was used in the analyses of chapters 3 , and 5 . In the conclusions above, it is shown that there is no sign of a clear sustainable development perspective in the studied policies. Also, some question marks can be placed regarding the "expressions of governance of sustainable development" as suitable characteristics. Thus, one could argue that the framework is not suitable.

The intention of the framework was to "better understand how the combination of various perspectives on sustainable development and different modes of governance create different strategies for implementation" (chapter 2). The framework was useful to recognise modes of governance and perspectives of sustainable development. Different modes of governance were clearly observed. Unexpectedly, equally clear perspectives on sustainable development were absent. The framework was set up under the assumption that there would be clear goals and visions defined. The fact that that was not the case, only points to a great weakness in current practices, and not to a weakness in the framework. The framework also helped to show that this weakness has consequences for governance: no adequate action can be taken without a vision of the desired future and clear goals.

The "expressions of governance for sustainable development" helped to identify several problematic areas in current practices, which is merit enough for maintaining them. However, they were not so prominently used in this thesis and could benefit from further research. 
This thesis has given quite a bit of attention to the roles and interactions of scientists/experts and policy makers. In chapter 6 the roles are described in some detail for the process of monitoring sustainable development. It would be useful to conduct similar exercises for other processes too. For instance, in the process of designing a vision of the desired future, different steps will have to be taken and different stakeholders will be involved. Setting up processes is not an easy thing to do. It needs careful thinking and experimenting. An awareness that roles differ, and that processes change over time and that different stakeholders might be involved at different phases within a process, will help the creation of an adequate adaptive governance structure.

In chapter 5 it was suggested that in order to create the space needed for innovations in achieving a sustainable future, and simultaneously have a structure for stability and recognition, working groups could be set up around roles and processes instead of setting up new institutions. "Old" institutions should not be abandoned, but are meant to provide structure. This needs specific research beyond what has been done in this thesis. For instance, we would still have a need for institutions to coordinate the processes and keep everyone on track it, but it should be studied how big the base organisation should be. In the case of looking at processes and roles, we need changes in current institutions. Research should investigate the feasibility of such a fundamentally different way of working in terms of allocation of funds, accountability, job security, etc.

A final question that requires some thought is about the role of scientists in operationalising sustainable development to help implementation. We have seen that scientists can take on different roles in the interaction with policy, and should ideally be clear on the role they fulfil. For this author, the role of honest broker seems to be the most appropriate one for pursuing sustainable development. It is not the mandate of researchers to steer society, but to show society the many possible roads and the consequences of their actions. However, what if no-one else takes the lead? One could think of a government that does not want to take action although they are aware of the importance of sustainable development, or of a the government that is ignorant of the importance of sustainable development, or of a failing government, where the state is unable to take action. Then who should take action? And in what capacity?

In such a case scientists should be aware that they are also citizens and have as such a responsibility to the country and community they live in. This responsibility goes beyond the official duties of citizens such as paying taxes and respecting the law and could be classified as social duty towards society. Obviously, this is not regulated by law and it would be rather strange to hear of someone being prose- 
cuted for not taking action on sustainable development although that person knew how important it was. However, acting on sustainable development on the grounds of being a responsible citizen would justify involvement of scientists in lobbying for action and in taking action. In such a case scientists should be clear to the outside world that they take on the role of the engaged citizen, who happens to have a scientific background.

In future, it would be worthwhile to clarify roles right from the beginning of any project. Of course, hidden agendas make this a rather utopian wish. But we could make a start with including in the VSNU ${ }^{25}$ Code of Conduct for Scientific Practice a chapter on the obligation to clarify the role you take on as a scientist in ethical and societal relevant research. This would fit within the Code's overarching principle of transparency

All in all, this thesis shows that many barriers to the implementation of sustainable development exist. It also provides ideas for solutions. The provincial or regional level seems to be well placed to take serious steps towards a sustainable future and to function as a frontrunner for the national level regarding implementation of sustainable development. A first step would be to develop a future oriented vision with that uses sustainable development as its guiding principle.

I sincerely hope the province of Limburg will continue its dedication to the implementation of sustainable development with a strong programme addressing these barriers, starting with the upcoming election period 2011-2015.

Annemarie van Zeijl-Rozema

\footnotetext{
${ }^{25}$ VSNU: Association of Universities in the Netherlands
} 



\section{$9 \quad$ Literature}

Aarts, W., Grin, J., 2006. En nu echt aan de slag met duurzame ontwikkeling! De prestaties van het rijk, bezien vanaf de werkvloer. Senter Novem, Utrecht.

Alvarez-Arenas, M., Miron, I., 2006. A flexible framework for regional sustainable development indicators using system thinking criteria (INSURE). In: Revista Internacional de Sotenibilidad, Tecnologia y Humanismo, Terrassa, 16-17 November 2006 pp. 41-59.

Anderson, P., 2010. The utility of operationalising the concept of skill ecosystems; the case of intermediate occupations in Scotland. Emerald 32: 435-452.

Astleithner, F., Hamedinger, A., Holman, N., Rydin, Y., 2004. Institutions and indicators - The discourse about indicators in the context of sustainability. Journal of Housing and the Built Environment 19: 7-24.

Bagheri, A., Hjorth, P., 2007. Planning for sustainable development: a paradigm shift towards a process-based approach. Sustainable Development 15: 83-96.

Bartelmus, P., Douglas, G., 2008. Indicators of sustainable development. Accessed on July 192009

Begg, I., 2009. Paving the way for a strategy of sustainable development. In: M.J. Rodrigues (Editor) Europe, Globalization and the Lisbon Agenda. Edward Elgar Publishing Limited, Cheltenham, pp. 283-293.

Bell, S., Morse, S., 2004. Experiences with sustainability indicators and stakeholder participation: a case study relating to a 'Blue Plan' project in Malta. Sustainable Development 12: 1-14.

Bell, S., Morse, S., 2005. Delivering sustainability therapy in sustainable development projects. Journal of Environmental Management 75: 37-51.

Böhringer, C., Jochem, P.E.P., 2007. Measuring the immeasurable -- A survey of sustainability indices. Ecological Economics 63: 1-8.

Börzel, T.A., 2006. Interim Report. New modes of governance and enlargement; when theory meets reality. NewGov project.

Börzel, T.A., Guttenbrunner, S., Seper, S., 2005. Conceptualizing new modes of governance in EU enlargement. NewGov project. 
Boulanger, P.-M., Bréchet, T., 2005. Models for policy-making in sustainable development: The state of the art and perspectives for research. Ecological Economics 55: 337-350.

Bouman, B.A.M., Jansen, H.G.P., Schipper, R.A., Nieuwenhuyse, A., Hengsdijk, H., Bouma, J., 1999. A framework for integrated biophysical and economic land use analysis at different scales. Agriculture, Ecosystems \& Environment 75: 55-73.

Brand, R., Karvonen, A., 2007. The ecosystem of expertise: complementary knowledges for sustainable development. Sustainability: Science, Practice and Policy 3: 21-31.

Bruno, I., Jacquot, S., Mandin, L., 2006. Europeanization through its instrumentation: benchmarking, mainstreaming and the open method of co-ordination ... toolbox or Pandora's box? Journal of European Public Policy 13: 519-536.

Bühler-Natour, C., Herzog, F., 1999. Criteria for sustainability and their application at a regional level: the case of clearing islands in the Dübener Heide nature park (Eastern Germany). Landscape and Urban Planning 46: 51-62.

Burch, S., In pursuit of resilient, low carbon communities: An examination of barriers to action in three Canadian cities. Energy Policy 38: 7575-7585.

Burger, P., 2006. Why any substantial definition of sustainability must fail - and why this is a good, not a bad story. In: Int. Sustainable Development Research Conference 2006, Hong Kong. (University of Hong Kong).

Buuren, A.v., 2009. Knowledge for Governance, Governance of Knowledge: Inclusive Knowledge Management in Collaborative Governance Processes. International Public Management Journal 12: 208-235.

Caratti, P., Ferraguto, L., 2008. Analysing Regional Sustainability Through a Systemic Approach: The Lombardy Case Study. FEEM No. 202.

Caratti, P., Ferraguto, L., Riboldi, C., 2006. Sustainable Development Data Availability on the Internet. FEEM No. 125.2006, Milan.

Caratti, P., Ravetz, J., Alvarez-Arenas, M., Schade, W., 2005. Bringing Sustainable Development vision into evaluation practice: a 'flexible framework' toolkit for assessing and benchmarking sustainability performance of European regions. In: Easy-Eco Conference: Impact Assessment for a New Europe and Beyond, Manchester. 
Cash, D.W., Clark, W.C., Alcock, F., Dickson, N.M., Eckley, N., Guston, D.H., Jager, J., Mitchell, R.B., 2003. Knowledge systems for sustainable development. PNAS 100: 8086-8091.

Clark, W.C., Dickson, N.M., 2003. Sustainability science: the emerging research program. PNAS 100: 8059-8061.

Collins, J., Thomas, G., Willis, R., Wilsdon, J., 2003. Carrots, sticks and sermons; influencing public behaviour for environmental goals.DEFRA

Committee of the Regions, 2005. Opinion on the 2005 review of the EU sustainable development strategy. pp. 1-7CdR 66/2005 fin.

Committee of the Regions, 2007. Outlook opinion of the CoR on the contribution of local and regional authorities to the European Union's sustainable development strategy. pp. 1-10CdR 85/2007 fin.

Dalal-Clayton, B., Krikhaar, F., 2007. A new sustainable development strategy: an opportunity not to be missed. pp. 6-144.RMNO A.10 (2007).

DEFRA, 2005. Securing the Future: The UK Government Sustainable Development Strategy. pp. 1-186.DEFRA

EU, 1997. Treaty of Amsterdam amending the Treaty on European Union, the Treaties establishing the European Communities and related acts. Official Journal of the European Union.

EU, 2000. Presidency conclusions of the Lisbon European Council, 23 and 24 March 2000. pp. 1-16.European Council

EU, 2001. European Governance; a white paper. pp. 1-35.European Commission $\operatorname{COM}(2001) 428$ final.

EU, 2005a. Annex to the 2005 review of the EU sustainable development strategy: stocktaking of progress; Commission staff working document. pp. 1-25.European Commission SEC(2005) 225.

EU, 2005b. Draft declaration on guiding principles for sustainable development; communication from the Commission to the Council and European Parliament. pp. 1-6.European Commission COM(2005) 218 final.

EU, 2005c. Sustainable Development Indicators to monitor the implementation of the EU Sustainable Development Strategy. pp. 1-20SEC(2005) 161 final. 
EU, 2006. Review of the EU Sustainable Development Strategy (EU SDS) - Renewed Strategy. pp. 1-29.Council of the European Union 10917/06.

EU, 2007. Leipzig Charter on sustainable European cities.

EU, 2008a. Green Paper on Territorial Cohesion: Turning territorial diversity into strength. pp. 1-13.European Commission $\{$ SEC(2008) 2550\}.

EU, 2008b. Sustainable Development - History; Milestones for Europe and the world. Accessed on 12/08/2009 2009

EU, 2009a. 2009 Review of the EU sustainable development stratgey - Presidency Report. pp. 1-22.C.o.t.E. Union

EU, 2009b. Conclusions of the European Council December 2009. pp. 1-19.E. Council

EU, 2009c. Impact assessment guidelines. pp. 1-50.European Commission SEC(2009) 92.

EU, 2009d. Mainstreaming sustainable development into EU policies: 2009 review of the European Union Startegy for sustainable development; Communication from the Commission to the European parliament, the Council, the European Economic and Social Committee and the Committee of the Regions. pp. 1-15.European Commission $\operatorname{COM(2009)} 400$ final.

EU, 2009e. Sustainable development in the European Commission. Accessed on 1692009

EU, 2009f. Sustainable development in the European Union; 2009 monitoring report of the EU sustainable development strategy (Introduction). pp. 1-30.Eurostat

Eurostat, 2007. Measuring progress towards a more sustainable Europe. Eurostat No. KS-77-07-115-EN-N, Luxembourg.

Farrell, K., Kemp, R., Hinterberger, F., Rammel, C., Ziegler, R., 2005. From *for* to Governance for Sustainable Development in Europe - what is at stake for further research. International Journal of Sustainable Development 8: 127-150.

Gibson, R.B., 2001. Specification of sustainability-based environmental assessment decision criteria and implications for determining 'significance' in environmental assessment. Canadian Environmental Assessment Agency Research and Development Programme No. 46. 
Glasbergen, P., Driessen, P.P.J., 2002. The paradigm shift in environmental politics. In: P.P.J. Driessen and P. Glasbergen (Editors), Greening Society, The Paradigm Shift in Dutch Environmental Policies. Kluwer Academic Publishers, Dordrecht, pp. 3-26.

Government of the Netherlands, 2007. Samen werken, samen leven. pp. 183. Ministerie van Algemene Zaken

Graymore, M.L.M., Sipe, N.G., Rickson, R.E., 2008. Regional sustainability: How useful are current tools of sustainability assessment at the regional scale? Ecological Economics 67: 362-372.

Greenport Venlo, 2008. Website Greenport Venlo. Accessed on June 2008

Grosskurth, J., 2007. Ambition and reality in modeling: a case study on public planning for regional sustainability Sustainability: Science, Practice, \& Policy (SSPP) 3: 311.

Grosskurth, J., Rotmans, J., 2005. The Scene Model: Getting A Grip On Sustainable Development In Policy Making. Environment, Development and Sustainability 7: 135-151.

Grundmann, R., 2009. The role of expertise in governance processes. Forest Policy and Economics 11: 398-403.

Hanney, S., Henkel, M., Walden Laing, D.v., 2001. Making and implementing foresight policy to engage the academic community: health and life scientists' involvement in, and response to, development of the UK's technology foresight programme. Research Policy 30: 1203-1219.

HarmoniCOP, 2005. Learning together to manage together; improving participation in water management. University of Osnabruck, Osnabruck.

Herrera-Ulloa, A., Charles, A., Lluch-Cota, S., Ramirez-Aguirre, H., HernandezVazquez, S., Ortega-Rubio, A., 2003. A regional-scale sustainable development index: the case of Baja California Sur, Mexico. International Journal of Sustainable Development and World Ecology 10: 353-360.

Huang, S.-L., Yeh, C.-T., Budd, W.W., Chen, L.-L., 2009. A Sensitivity Model (SM) approach to analyze urban development in Taiwan based on sustainability indicators. Environmental Impact Assessment Review 29: 116-125.

Hueting, R., Reijnders, L., 2004. Broad sustainability contra sustainability: the proper construction of sustainability indicators. Ecological Economics 50: 249-260. 
Huggins, R., 2008. Regional Competitive Intelligence: Benchmarking and Policymaking. Regional Studies.

Huppes, G., Simonis, U.E., 2008. Environmental Policy Instruments. In: J. Boersema and L. Reijnders (Editors), Principles of Environmental Sciences, pp. 239-280.

IHDP, 2008. Knowledge and Social Learning for Societal Change and Sustainability: Developing a new Cross-Cutting Research Theme for IHDP. IHDP Secretariat, Bonn, Germany.

IISD, 2007. What is sustainable development? Accessed on 15 May 2007

IISD, JRC, 2009. The Millennium Development Goals Dashboard.

ILO, 2004. Mainstreaming and operationalisation of the Decent Work Agenda throught he Poverty Reduction Strategy Papers (PRSPs), PowerPoint presentation.

iNSnet, 2006. iNSnet Duurzaamheid Monitor 2006 (summary). Accessed on 15 October 2010

iNSnet, 2007. iNSnet Duurzaamheid Monitor 2007 (summary). Accessed on 15 October 2010

iNSnet, 2008. iNSnet Duurzaamheid Monitor 2008 (summary). Accessed on 15 October 2010

INSURE, 2003. Description of Work (Annex I)- INSURE, a flexible framework for indicators for sustainability in regions using system dynamics modelling. pp. 1-99.

INSURE, 2007a. Final case study reports.

INSURE, 2007b. Guidelines to develop a S-indicator - WP4. pp. 1-78.

Interviews GV, 2008-2009. Interviews with programme and project managers of GV. (A.E. van Zeijl-Rozema.

Interviews LvDO, 2008-2009. Interviews with programme and project managers of LvDO. (A.E. van Zeijl-Rozema.

Jesinghaus, J., 1999. Indicators for Decision-Making. JRC, working paper, Ispra.

Jiliberto Herrera, R., 2006. A new system epistemology for sustainable development analysis. International Journal of Sustainable Development 9: 211-226. 
Jiliberto Herrera, R., 2008. The INSURE System mapping model: a qualitative system model to describe the system of the regional sustainability. In 'Easy-Eco Conference'. Vienna).

JRC, 2002. State-of-the-art Report on Current Methodologies and Practices for Composite Indicator Development. pp. 1-72.Institute for the Protection and Security of the Citizen; Technological and Economic Risk Management EUR 20408 EN.

JRC, 2005. Tools for Composite Indicators Building. pp. 1-134.Institute for the Protection and Security of the Citizen; Econometrics and Statistical Support to Antifraud Unit EUR 21682 EN.

Kates, R.W., Clark, W.C., et al., 2001. Sustainability Science. Science 292: 641-642.

Keil, A., 2006. New urban governance processes on the level of neighbourhoods. European Planning Studies 14: 335-364.

Kellerman, A.A., 2006. Duurzame overheid? Tijd voor duurzaam leiderschap. Senter Novem, Utrecht.

Kelly, R., Moles, R., 2002. The Development of Local Agenda 21 in the Mid-west Region of Ireland: A Case Study in Interactive Research and Indicator Development. Journal of Environmental Planning and Management 45: 889 - 912.

Kemp, R., Loorbach, D., 2005. Dutch Policies to Manage the Transition to Sustainable Energy. In: F. Beckenbach, U. Hampicke, C. Leipert, G. Meran, J. Minsch, H.G. Nutzinger, R. Pfriem, J. Weimann, F. Wirl and U. Witt (Editors), Jahrbuch Ökologische Ökonomik 4, Innovationen und Nachhaltigkeit. MetropolisVerlag, Marburg, pp. 123-150.

Kemp, R., Loorbach, D., Rotmans, J., 2007. Transition management as a model for managing processes of co-evolution towards sustainable development. In: Special issue on (co)-evolutionary approach to sustainable development, The International Journal of Sustainable Development and World Ecology, pp. 78-91.

Kemp, R., Martens, P., 2007. Sustainable development: how to manage something that is subjective and can never be achieved? Sustainability: Science, Practice and Policy 3: 1-10.

Kemp, R., Parto, S., Gibson, R.B., 2005. Governance for sustaianble development: moving from theory to practice. International Journal of Sustainable Development 18: $12-30$.

King, C., Gunton, J., Freebairn, D., Coutts, J., Webb, I., 2000. The sustainability indicator industry: where to from here? A focus group study to explore the potential of 
farmer participation in the development of indicators. Australian Journal of Experimental Agriculture 40: 631-642.

Kondyli, J., 2010. Measurement and evaluation of sustainable development: A composite indicator for the islands of the North Aegean region, Greece. Environmental Impact Assessment Review 30: 347-356.

Kooiman, J., 2003. Governing as Governance. SAGE Publications, London.

Lafferty, W.M., 2004. Chapter 1. Introduction: form and function in governance for sustainable development. In: W.M. Lafferty (Editor) Governance for Sustainable Development: the challenge of adapting form to function. Edward Elgar Publishing Ltd., Cheltenham, pp. 1-31.

Lamers, M., Ottow, B., Francois, G., Korff, Y.v., 2010. Beyond dry feet? Experience from a participatory water management planning case in the Netherlands. Ecology and Society 15: online.

Lamy, P., Laidi, Z., 2002. A European Approach to Global Governance. Progressive Politics 1.

Lawrence Neuman, W., 2003. Social research methods; qualitative and quantitative approaches. Allyn and Bacon, Boston.

Loorbach, D., Kemp, R., 2007. Transition management for the Dutch energy transition: the multilevel governance aspects. In: J.C.J.M.v.d. Bergh and F.R. Bruinsma (Editors), The Transition to Renewable Energy: Theory and Practice. Edward Elgar Publishing Ltd., Cheltenham.

Lütkenhorst, W., 1982. Operationalising basic needs: A few fundamental reflections. Intereconomics 17: 244-250.

LvDO, 2003. Nota leren voor duurzame ontwikkeling: van marge naar mainstream. pp. 1-64

Martens, P., 2006. Sustainability: science or fiction? Sustainability: Science, Practice and Policy 2: 1-5.

Martens, P., Raza, M., 2009. The Maastricht Globalisation Index: an update. In: H.V. Baines and J.R. Ursah (Editors), Globalization: Understanding, Management and Effects. Nova Science Publisher, Inc, New York, pp. 279-309.

Martinez-Alier, J., Munda, G., O'Neill, J., 1998. Weak comparability of values as a foundation for ecological economics. Ecological Economics 26: 277-286. 
Mayer, A.L., 2008. Strengths and weaknesses of common sustainability indices for multidimensional systems. Environment International 34: 277-291.

Mayer, A.L., Thurston, H.W., Pawlowski, C.W., 2004. The multidisciplinary influence of common sustainability indices. Frontiers in Ecology and the Environment 2: 419426.

McCool, S.F., Stankey, G.H., 2004. Indicators of sustainability: challenges and opportunities at the interface of science and policy. Environmental Management 33: 294-305.

McManus, P., 2008. Mines, Wines and Thoroughbreds: Towards Regional Sustainability in the Upper Hunter, Australia. Regional Studies 42: 1275 - 1290.

Mendoza, G.A., Prabhu, R., 2006. Participatory modeling and analysis for sustainable forest management: Overview of soft system dynamics models and applications. Forest Policy and Economics 9: 179-196.

Meuleman, L., in 't Veld, R.J., 2009. Sustainable development and the governance of long-term decision-Executive Summary. In: EEAC Working Group Governance, pp. 4-18. (RMNO).

Mickwitz, P., Melanen, M., 2009. The role of co-operation between academia and policymakers for the development and use of sustainability indicators - a case from the Finnish Kymenlaakso Region. Journal of Cleaner Production 17: 1086-1100.

Miller, C.A., 2007. Creating Indicators of Sustainability; A social approach. IISD.

Morgan, K., 2004. Sustainable Regions: Governance, Innovation and Scale. European Planning Studies 12: 871-889.

MPA (National Marine Protected Areas Center), 2004. Stakeholder Participation: A Synthesis of Current Literature. pp. 1-24.N.M.P.A.C. (USA)

Munda, G., 2005. "Measuring Sustainability": A Multi-Criterion Framework. Environment, Development and Sustainability 7: 117-134.

MVO Platform, 2007. MVO Referentiekader. Accessed on February 2009

Noll, H.-H., 2002. Towards a European System of Social Indicators: Theoretical Framework and System Architecture. Social Indicators Research 58: 47-87.

Noordegraaf, M., van Lierop, K., 2006. Duurzaam besturen; bijdragen van beleidsmakers aan duurzame ontwikkeling. Senter Novem, Utrecht. 
Nuissl, H., Haase, D., Lanzendorf, M., Wittmer, H., 2009. Environmental impact assessment of urban land use transitions--A context-sensitive approach. Land Use Policy 26: 414-424.

Onderzoeksbureau EIM, 2008. Aansluiten, mee veren en ombuigen. pp. 1-50.LvDO

Ozkaynak, B., Devine, P., Rigby, D., 2004. Operationalising Strong Sustainability: Definitions, Methodologies and Outcomes. Environmental Values 13: 279-303.

Pallemaerts, M., 2006. The EU and Sustainable Development: An Ambiguous Relationship. In: M. Pallemaerts and A. Azmanova (Editors), The European Union and Sustainable Development: Internal and External Dimensions. VUBPress, Brussels, pp. 19-52.

Pareglio, S., Vaglio, A., Grasso, M., Mighavacca, S., Giulio, E.D., 2005. Modelling sustainable human development in a capability perspective. Accessed on July 2009

Parris, T.M., Kates, R.W., 2003. Characterizing and measuring sustainable development. Annual Review of Environment and Resources 28: 559-586

Pearsall, H., Pierce, J., 2010. Urban sustainability and environmental justice: evaluating the linkages in public planning/policy discourse. Local Environment: The International Journal of Justice and Sustainability 15: 569-580.

Phillis, Y.A., Andriantiatsaholiniaina, L.A., 2001. Sustainability: an ill-defined concept and its assessment using fuzzy logic. Ecological Economics 37: 435-456.

Pielke Jr., R.A., 2007. The honest broker; making sense of science in policy and politics. Cambridge University Press, Cambridge.

Pirk, S., 2002. Expanding Public Participation in Environmental Justice: Methods, Legislation,Litigation and Beyond. Journal of Environmental Law and Litigation 17: 207-240.

Potschin, M., Haines-Young, R., 2008. Sustainability Impact Assessments: limits, thresholds and the Sustainability Choice Space In: K. Helming, M. Pérez-Soba and P. Tabbush (Editors), Sustainability Impact Assessment of Land Use Changes Springer, pp. 425-450.

Province of Limburg, 2001. Provinciaal Omgevinsplan Limburg (POL). pp. 1-302

Province of Limburg, 2003. Limburg verlegt grenzen; coalitieakkoord 2003-2007. pp. 1-40 
Province of Limburg, 2004. Subisidiewijzer leren voor duurzame ontwikkeling; PASsie voor Limburg. pp. 1-10

Province of Limburg, 2005a. Duurzaamheid duurt het langst; Programma Duurzaam Limburg 2005-2007. pp. 1-32

Province of Limburg, 2005b. Heuvelland samen...natuurlijk bereikbaar; uitvoeringsplan toeristisch-recreatief verkeer Heuvelland.Afdeling Mobiliteit

Province of Limburg, 2005c. Limburgmonitor pp. 1-144

Province of Limburg, 2005d. Versnellingsagenda 2005: Limburg op weg naar 2012. 1-121.

Province of Limburg, 2006. Trendrapport: inspiratie voor de bestuursperiode 20072011. pp. 1-75

Province of Limburg, 2007a. Evaluatie coalitieakkoord 2003-2007. pp. 1-92.A.S.e. Innovatie

Province of Limburg, 2007b. Investeren en verbinden; Coalitieakkoord 2007-2011. pp. 1-21

Province of Limburg, 2008. Provinciaal Omgevingsplan Limburg 2006, actualisatie januari 2008.

Province of Limburg, 2009a. Beleidskader Duurzame Ontwikkeling/Cradle to Cradle 2008-2011. pp. 1-41.Afd. Milieu en Duurzame Ontwikkeling

Province of Limburg, 2009b. Limburgmonitor pp. 1-134

Province of Limburg, 2010a. Bevolkingsonderzoek Limburg 2010.

Province of Limburg, 2010b. Duurzaamheidparagraaf in PS-voorstellen en Meetbare duurzaamheid van BBO's en bouwprojecten. pp. 1-6.MDOMI DOC201000029874.

Provincie Limburg (Belgie), 2006. Duurzaamheidsbarometer Limburg.

Putzhuber, F., Hasenauer, H., 2010. Deriving sustainability measures using statistical data: A case study from the Eisenwurzen, Austria. Ecological Indicators 10: 3238. 
Rammel, C., van den Bergh, J., 2002. An Evolutionary Perspective on Sustainable Development Policies: Adaptive Flexibility and Risk Minimising. Ecological Economics 47: 121-133.

Ramos, T.B., 2009. Development of regional sustainability indicators and the role of academia in this process: the Portuguese practice. Journal of Cleaner Production 17: 1101-1115.

Ramos, T.B., Caeiro, S., 2009. Meta-performance evaluation of sustainability indicators. Ecological Indicators 10: 157-166.

Ravetz, J., 2004. Evaluation of regional sustainable development - mapping the landscape. Journal of Environmental Assessment Policy and Management 6: v-xxi.

Ravetz, J., 2007. The role of evaluation in regional sustainable development. In: C. George and C. Kirkpatrick (Editors), Impact Assessment and Sustainable Development. Edward Elgar Publishing Limited, Cheltenham, pp. 65-89.

Ravetz, J.R., 1999. What is post-normal science? Futures 31: 647-653.

Reed, M.S., Fraser, E.D.G., Dougill, A.J., 2006. An adaptive learning process for developing and applying sustainability indicators with local communities. Ecological Economics 59: 406-418.

Regeer, B.J., Hoes, A.-C., van Amstel-van Saane, M., Caron-Flinterman, F.F., Bunders, J.F.G., 2009. Six Guiding Principles for Evaluating Mode-2 Strategies for Sustainable Development. American Journal of Evaluation 30: 515-537.

Reitan, P., 2005. Sustainability science - and what's needed beyond science. Sustainability: Science, Practice and Policy 1: 77-80.

Research Institute for Managing Sustainability (RIMAS), 2009. Contributions of the regional and local authorities to sustainable development strategies-conclusions. pp. 165-188. (European Union.

Rinzin, C., Vermeulen, W.J.V., Glasbergen, P., 2007. Public perceptions of Bhutan's approach to sustainable development in practice. Sustainable Development 15: 5268.

RIVM, 1999. Life support functies van de bodem: operationalisering t.b.v. het biodiversiteitsbeleid. RIVM No. 607601003, Bilthoven.

Robinson, J., 2004. Squaring the circle? Some thoughts on the idea of sustainable development. Ecological Economics 48: 369-384. 
Ronchi, E., Federico, A., Musmeci, F., 2002. A system oriented integrated indicator for sustainable development in Italy. Ecological Indicators 2: 197-210.

Runhaar, H., 2009. Putting SEA in context: A discourse perspective on how SEA contributes to decision-making. Environmental Impact Assessment Review 29: 200209.

Schade, W., Krail, M., Caratti, P., Riboldi, C., 2006. INSURE system model: a generic model for socio-economic and environmental analysis of European regions. In: International Conference on Regional and Urban Modelling, Brussels, Belgium.

Scholz, R.W., Tietje, O., 2002. Embedded case study methods; integrating quantitative and qualitative knowledge. Sage Publications, Inc., Thousand Oaks.

Searle, J.R., 2005. What is an institution? Journal of Institutional Economics 1: 1-22.

Senter Novem, 2008. Leerwerkgroep C2C; vierde bijeenkomst (powerpoint). Accessed on 16-9 2009

Smismans, S., 2006. New modes of governance and the participatory myth. European Governance Papers No. N-06-01.

Sneddon, C., Howarth, R.B., Norgaard, R.B., 2006. Sustainable development in a post-Brundtland world. Ecological Economics 57: 253-268.

Spaargaren, G., 2003. Sustainable Consumption: A Theoretical and Environmental Policy Perspective. Society \& Natural Resources: An International Journal 16: 687 701.

Spangenberg, J.H., 2002. Environmental space and the prism of sustainability: frameworks for indicators measuring sustainable development. Ecological Indicators 2: 295-309.

Spangenberg, J.H., 2005. Economic sustainability of the economy: concepts and indicators. International Journal of Sustainable Development 8: 47-64.

Steinbuka, I., Wolff, P., 2007. Indicators and better policy-making: the case of sustainableDevelopment. . 1-7.

Stevenson, F., Ball, J., 1998. Sustainability and materiality: The bioregional and cultural challenges to evaluation. Local Environment 3: 191-209.

Swyngedouw, E., 2005. Governance innovation and the citizen: the Janus face of governance-beyond-the-state. Urban Studies 42: 1991-2006. 
Sydnes, A.K., 2001. Establishing a regional fisheries management organisation for the Western and Central Pacific tuna fisheries. Ocean \& Coastal Management 44: 787-811.

Termeer, C., 2009. Barriers to new modes of horizontal governance. Public Management Review 11: 299-316.

Termeer, C.J.A.M., Kranendonk, R.P., 2008. Governance of regional innovations towards sustainability. In 'European Group of Public Administration (EGPA) Conference'. Rotterdam).

Termeer, K., 2008. Third generation governance. In 'Dies Natalis, WUR, Lustrum Symposium on Science and Governance'. Wageningen, the Netherlands).

Transforum, 2008. WebsiteTransforum, project Streamlining Greenport Venlo. Accessed on June 2008

Treib, O., Bähr, H., Falkner, G., 2005. Modes of Governance: a note towards conceptual clarification. European Governance Papers No. N-05-02.

UN, 1992. Agenda 21 - Earth Summit; The United Nations Programme of Action from Rio.

UN, 2001a. Guidance in preparing a national sustainable development strategy: managing sustainable development in the new millennium.DESA DESA/DSD/PC2/BP13.

UN, 2001b. Implementing Agenda 21. Report of the Secretary-General. pp. 169.Economic and Social Council E/CN.17/2002/PC.2/7.

UN, 2002. Plan of Implementation of the World Summit on Sustainable Development.

UN, 2007. Indicators of Sustainable Development: Guidelines and Methodologies (3rd edition). pp. 1-99.DESA ISBN 978-92-1-104577-2.

UNDESA, 2001. Guidance in preparing a national sustainable development strategy: managing sustainable development in the new millennium. No. DESA/DSD/PC2/BP13.

UNDP, 2007. Human Development Report 2007/2008; Fighting climate change: human solidarity in a divided world. Palgrave Macmillan, New York. 
van Bueren, E., ten Heuvelhof, E., 2005. Improving governance arrangements in support of sustainable cities. Environment and Planning B: Planning and Design 32: 47-66.

van den Hove, S., 2000. Participatory approaches to environmental policy-making: the European Commission Climate Policy Process as a case study. Ecological Economics 33: 457-472.

van der Woude, N., 2008. Het vermogen om duurzaam te ontwikkelen; acht kwaliteiten voor duurzame ontwikkeling. Senter Novem, Utrecht.

Veal, A.J., 2006. Research methods for leisure and tourism; a practical guide. Pearson Education Ltd, Harlow.

Viglizzo, E.F., Pordomingo, A.J., Castro, M.G., Lertora, F.A., 2003. Environmental assessment of agriculture at a regional scale in the pampas of Argentina. Environmental Monitoring and Assessment 87: 169-195.

Voß, J.-P., Kemp, R., 2006. Sustainability and reflexive governance: introduction. In: J.-P. Voß, D. Bauknecht and R. Kemp (Editors), Reflexive Governance for Sustainable Development. Edward Elgar Publishing Ltd., Cheltenham.

VROM, 2001. Een wereld en een wil: werken aan duurzaamheid; Nationaal Milieubeleidsplan 4 - Samenvatting.VROM

VROM, 2003. Duurzame daadkracht; Actieprogramma duurzame ontwikkeling. pp. 5-104.VROM

VROM, 2008. Kabinetsbrede aanpak duurzame ontwikkeling. pp. 1-11.VROM DGM/BREM2008050615.

VROM, 2009. Dossier Duurzame Ontwikkeling Algemeen. Accessed on 12/08/2009 2009

Wallis, A.M., 2006. Sustainability indicators: is there consensus among stakeholders? International Journal of Environment and Sustainable Development 5: 287 $-296$

Weimer-Jehle, W., 2006. Cross-impact balances: A system-theoretical approach to cross-impact analysis. Technological Forecasting and Social Change 73: 334-361.

Wiek, A., Binder, C., 2005. Solution spaces for decision-making-a sustainability assessment tool for city-regions. Environmental Impact Assessment Review 25: 589-608. 
Wiek, A., Lang, D.J., Siegrist, M., 2008. Qualitative system analysis as a means for sustainable governance of emerging technologies: the case of nanotechnology. Journal of Cleaner Production 16: 988-999.

Wilson, J., Tyedmers, P., Pelot, R., 2007. Contrasting and comparing sustainable development indicator metrics. Ecological Indicators 7: 299-314.

World Commission on Environment and Development, 1987. Our Common Future. Oxford University Press, Oxford.

Zeijl-Rozema van, A., Cörvers, R., Kemp, R., Martens, P., 2008. Governance for sustainable development: a framework. Sustainable Development 16: 410 - 421.

Zeijl-Rozema van, A., Ferraguto, L., Caratti, P., 2011. Comparing region-specific sustainability assessments through indicator systems: Feasible or not? Ecological Economics 70: 475-486.

Zeijl-Rozema van, A., Martens, P., 2010. An adaptive indicator framework for monitoring regional sustainable development: a case study of the INSURE project in Limburg, The Netherlands. Sustainability: Science, Practice and Policy 6: 6-17.

Ziegler, R., 2009. The politics of operationalisation: sustainable development and the eco-space approach. Environmental Politics 18: 163 - 181.

Zijst, H.v., 2006. Sustainable Development Strategy of the Netherlands; Background report for the peer review of SDS in the Netherlands 2007. RMNO No. V.09 (2006), The Hague.

Zilahy, G., Huisingh, D., 2009. The roles of academia in Regional Sustainability Initiatives. Journal of Cleaner Production 17: 1057-1066.

Zilahy, G., Huisingh, D., Melanen, M., Phillips, V.D., Sheffy, J., 2009. Roles of academia in regional sustainability initiatives: outreach for a more sustainable future. Journal of Cleaner Production 17: 1053-1056. 


\section{Summary}

At different scale levels a gap in implementation of sustainable development policy can be seen. This thesis investigates the gap in implementation of sustainable development in the Province of Limburg, the Netherlands. The concept of sustainable development requires that we see the planet and our world as a system. A system that connects space ('here and there') and a system that connects time ('now and later'). A central feature of sustainable development is that we adopt an integrated vision. Simultaneously, sustainable development can be seen as a political or normative act, rather than a scientific concept. Sustainable development is after all about the quality of life we desire now and in future. The desired future will be different, from place to place, and from person to person. Hence, we have to accept that many views on sustainable development exist. The power of the concept is that it brings the differences in world views and in contradictions in current behaviour to the surface and provides a playing field for the debate.

Consequences of unsustainable development often only become visible in the long run or elsewhere, whereas a disruption of, for instance, water supply has immediate consequences. Sustainable development receives support at government level and in society, but a general notion of urgency leading to action seems to be missing. Individual benefits that are clear in sanitation or health are not so clear in sustainable development. In such a case governance is needed to shape the societal process of change towards sustainable development.

Governance for sustainable development has to deal with uncertainty, a diffuse responsibility of impacts, complexity at systemic level and among actors and sectors, large temporal and spatial scales, and possible irreversibility of processes. A theoretical framework has been developed in this thesis to better understand the barriers we encounter in the implementation of sustainable development. This framework maps out different modes of governance and different perspectives on sustainable development. (Chapter 2) Governance for sustainable development requires dynamic problem solving, conflict resolution, integration of information, involvement of the different actors at many levels, coordination across policy areas and vision, goals, benefits and concreteness. All in all, this is not an easy task. But, what exactly are the problems that we currently face? To that end this thesis investigated barriers for implementing sustainable development in practice from various perspectives: policy, population, practitioners and monitoring.

\section{Sustainable development policy (chapter 3)}

In the last decades policy has been developed that is specifically aimed at realising sustainable development. Especially since the commitment to the Johannesburg Plan of Implementation, many countries have developed a national sustainable 
development strategy. In this thesis several policy developments with respect to sustainable development have been mapped out at various scale levels. The strong and weak points of these policies were investigated, and the question was asked whether sustainable development needs specific policy, or whether it would be better to use sustainable development as a guiding principle for policy and what that would mean.

Two observations can be made on sustainable development policy development: For a long time sustainable development was seen from an environmental perspective, even after the Rio Conference where sustainable development was introduced as an integrative, interdisciplinary concept dealing with inter-and intra-generational equity issues. Furthermore, it takes considerable time for a global issue to be transformed into regional policy.

The Limburg sustainable development strategy (SDS) was investigated within its national and European context. Thus three policies of sustainable development were investigated in more detail: the $\mathrm{EU} \mathrm{SDS}^{26}$, the Dutch $\mathrm{KADO}^{27}$ and the Limburg $\mathrm{SDS}^{28}$. Each of the policies has integratedness as a starting point: sustainable development is a cross-cutting issue and is a process more than anything else. However, analysis showed that these policies pose a barrier to an integrated approach by their lack of links between scale levels, their focus on environment, and their approach that places sustainable development and associated icon projects in a special niche. Therefore, the thesis continued by investigating what it would mean if these policies really pursued integratedness and operationalised sustainable development as a cross-cutting issue. That would mean that every action, every design, every production process and every decision should be taken in the light of sustainable development. For this a broad vision of the desired future is important. Subsequently, policy and actions should be designed to help realise this vision. These policies and actions, as well as the vision of the future, need to undergo a sustainability check. Instead of defining key challenges for sustainable development, which is the current practice, key challenges should be defined for society to achieve its goals. It is of vital importance to understand that sustainable development is not the goal to be achieved; the goal is to achieve the desired future. Sustainable development is a way in which to realise that future. A checklist for sustainable development has been designed in this thesis to help to make a sustainability check of vision, policy and actions. New avenues for implementation could be opened up if sustainable development is used as a guiding principle, with criteria that are applied to every policy and action.

\footnotetext{
${ }^{26}$ EU 10917/06 Renewed EU sustainable development strategy

${ }^{27}$ VROM DGM/BREM2008050615 Kabinetsaanpak Duurzame Ontwikkeling (KADO)

${ }^{28}$ Provincie Limburg, Beleidskader Duurzame Ontwikkeling/ Cradle to Cradle 2008-2011
} 


\section{The Limburg population (chapter 4)}

Implementation of sustainable development requires cooperation of actors of state, market and civil society. It is known that citizens think that government should take the lead in sustainable development and show by example what should be done. But the government cannot implement sustainable development alone. An assumption in this research was that one reason why implementation fails is because people are unfamiliar with the concept, the concept is too abstract and is not well understood. However, it was also assumed that people do take actions that fall within the context of sustainable development without being called that. Therefore, a survey was conducted in Limburg to find answers to these assumptions. An internet questionnaire was sent out to 1281 people and out of that 910 people have responded.

The major conclusions of the survey are that people understand sustainable development at an abstract level, but interpret it as environment at a concrete level. People think sustainable development is important. Economy is not seen as a significant dimension of sustainable development.

The question whether people show sustainable behaviour but don't call it that, showed that people say they are sustainable and want to become even more sustainable, but they do not act sustainable (yet). Their behaviour is mainly driven by quality and cost considerations.

Regarding leadership in sustainable development, people see government as the most important player to take the lead, but they see a role for the other players too. Vision and goal formulation is seen as the most important instrument for all stakeholders, followed by taking action.

Not only did the survey results show us what the current status of sustainable development thinking and acting is in Limburg, but it also showed many opportunities for improvement.

First of all, it is clear that information is needed on sustainable development. More specifically, people need to know about the interrelatedness of the social, environmental and economical domains and time and space. Furthermore, they need information on the individual benefits, effects of sustainable behaviour and examples of concrete actions they can take.

Secondly, actions that people take can be made more sustainable by making the sustainable options the easiest ones, providing product information, helping people to determine the sustainability of their actions, and offering alternative mobility solutions that ensure speed and accessibility.

Thirdly, an enabling environment can be created that helps these changes along. Because government is seen to be so important and because sustainable development is such a long term affair, government seems to be ideally placed to coordinate the creation of an enabling environment. Furthermore, government should develop a vision, set goals, take action and provide legislation and regulation. For 
that matter, a vision, goals and taking action were thought to be important for all actors. However, each party is also expected to play specific roles.

In general it has become clear that certain groups need to be approached specifically dependent on e.g. age, gender, education.

It is important to note that the three clusters of providing information, stimulating action and creating an enabling environment are interrelated and mutually reinforcing and therefore should be addressed in parallel.

\section{Practioners' perspective (chapter 5)}

To find out more about current barriers, sustainable development practitioners were asked about their experiences in two case studies in Limburg: Greenport Venlo (GV) and the programme Learning for Sustainable Development (LvDO) in Limburg. These cases were chosen because of their different modes of governance towards regional (sustainable) development. Greenport Venlo is a voluntary network organisation that is characterised by deliberation. Learning for sustainable development is a government subsidised programme that follows a more traditional top down approach. The analysis of the two case studies zoomed in on differences and similarities between the cases in order to learn more about current problems and practices. Questions were asked to find out more about the mode of governance, about how sustainable development was understood and about problems and practices within the case study.

Content-wise, the problem seems to be not so much whether the perspective on sustainable development is ecological or well-being, but that the goal is vague and benefits are unclear, thus making it very difficult to communicate with people. The majority of problems seems to be related to governance issues (institutions, actors, processes and instruments). More specifically, actors cannot always be reached, or they are not committed to or interested in sustainable development. Important skills of process managers are not always present in government institutions. Tension exists between new deliberative approaches and hierarchical structures. The problem is how to provide structure and maintain innovation space at the same time. In LvDO we see this tension reflected in a fear, or resistance, to change in the provincial administration.

Most practices, or actions taken to make the projects within the case studies a success, relate to governance. This does not mean that sustainable development is less important than governance. Sustainable development requires vision and clarity about the direction. But achieving sustainable development is a complex governance issue. Not surprisingly, many practices focused on stakeholders. In both case studies we observed that stakeholders are of great importance. If they do not take part, not much will happen. For that purpose, process facilitators with proper skills are important. They should be able to motivate stakeholders, mediate when necessary, make connections, facilitate difficult processes, provide information, 
reflect on the process, etc. A mix of approaches (hierarchical and deliberative) is used and many different types of meetings and organisations are used.

Regarding similarities and differences of the two case studies we can state that the sustainable development perspective used in both case studies is one of well-being, which seems to be implemented in practice in the sphere of environment. This is not different from the findings in various other chapters. The search in GV is for more structure, but, at the same time, to maintain openness for innovation. GV has benefited from the process resulting in the vision document. In LvDO structural issues were rare, because the structure was straightforward. Instead, commitment issues and getting stakeholders interested were more prominent

What lessons can we learn from these results? The focus placed on governance in these two case studies is an expression of the wickedness of sustainable development. If sustainable development were simpler, we would have less governance issues enveloping it. Clarifying the sustainable development vision, goals and benefits will not eliminate all governance issues, but will help to focus on the really important things: finding new forms of governance for moving towards sustainable development. Furthermore, a mix of governance approaches would be appropriate while the "old" institutions should not be forgotten. At the same time it is clear that traditional governance structures are not suitable for sustainable development.

Sustainable development is about living, working, and acting in a different way. If we wish to steer such a process, we are dealing with a wicked issue for which there is no blueprint solution. This implies a new role for government in creating an enabling environment where implementation can take place.

\section{Monitoring sustainable development (chapters 6 and 7)}

Because the results of sustainable development efforts often only become visible after a long period of time, it is necessary to monitor the implementation of processes as they unfold. Continuous appraisal helps to make progress visible and to steer processes in the appropriate direction. The measurement of regional sustainable development includes several elements: a capacity for flexibility that includes a set of region-specific characteristics, a proper system description, and a vision of sustainable development that determines regional priorities. Once these prerequisites are in place, it becomes possible to assess regional sustainability. However, when we started a monitoring exercise for the Limburgmonitor 2007, it became clear that policy in Limburg lacked a long-term vision on regional sustainable development.

As a consequence, the expert group working on regional monitoring did not want to interfere with what its members saw as a role for policy makers by setting their own priorities for sustainable development in Limburg. Therefore, the regional framework remained rather indistinct and was based simply on the three pillars of 
sustainable development which is a concept that is already being used in Limburg: society, economy, and ecology. Furthermore, the absence of sustainability goals and criteria for interpretation became a major barrier to conducting a successful sustainability assessment. Due to the absence of policy-making input into the process, problems arose at several stages of the monitoring process. This monitoring project made clear that at all stages of measuring sustainable development, the involvement and cooperation of relevant policy makers and technical experts is essential.

\section{Conclusion (chapter 8)}

Sustainable development is a complex process that requires an integrated approach. This in itself is a barrier to implementation. However, complexity can be made manageable. For sustainable development this would require a vision of the desired future and linked to that vision, goals to be achieved. However, precisely a vision and goals are often lacking in policies at various levels, although stakeholders see it as important at all levels and for all stakeholders to have a vision and goals. Right now there is often a general vision of a country or region and, sometimes, separately, a sustainable development vision. It would be more useful to make a general vision of the desired future at each scale level that includes sustainable development as a guiding principle. The reason for this is that given the integratedness of the concept it makes little sense to confine it to its own niche with its own restricted vision. Nor does it make sense to make a sustainable development vision for the country or region, which is different from the general vision.

Furthermore, dealing with complexity can be done by breaking up a complex issue into smaller areas for taking action. This is done, but results are not merged to see progress towards the desired future. Essential is that during the process of implementation the results of the actions are evaluated against goals and vision to see what progress has been made towards achieving the vision.

What is also missing is an enabling environment that will help to implement sustainable development. An enabling environment helps, instead of obstructs, sustainable development by providing vision and coordination where necessary. Such an environment would encourage action, connect people, and provide structure as well as space for innovation. Process managers with the proper skills are thus of great importance.

A mix of hierarchical and deliberative approaches is necessary. Structure is required, but also space for innovation. Instead of establishing new institutions, it seems more practical to define themes, processes and roles that are necessary and form groups around these. After each revision of the desired future and of pathways to achieve it, new roles and processes might become necessary, which means a flexible and adaptive structure is important. It is thought that a core institution such as the provincial administration is needed to serve as coordinator and facilita- 
tor, with the ability to connect different parties and with a responsibility in safeguarding monitoring.

Currently, environmental consciousness is mainstream, but sustainable development consciousness is not. We saw in policy a rather indistinct way of thinking about sustainable development. This does not help implementation. It seems that the full concept of sustainable development with its integratedness and temporal and spatial implications has not yet landed. Because sustainable development is presented as well-being, but is implemented as environmental protection an inconsistent perspective on sustainable development is the result. For a topic that is so complex already, and that is surrounded by debate, obviously such an inconsistency only increases vagueness.

Another important barrier towards acting more sustainable is the lack of knowledge about concrete actions that people can take, which could be remedied by an information campaign. However, many people also say that they are only willing to take action if the individual benefits are clear. In other words, they are asking for incentives for becoming more sustainable. At the same time, people indicated they want to change in an easy way. As benefits of behaving in a sustainable way are likely to have returns only in the long term and probably at the collective rather than the individual level, an information campaign only will not result in more sustainable action. But there is another side to the request for incentives. Although many people understand that sustainable development is about a balance between the environmental, social and economic domain, at a concrete level economy was mentioned very little as playing a role in sustainable development. This means that when people were asked about concrete examples of sustainable development, economic issues were not mentioned. People's actions, however, are mainly driven by economic considerations and quality. If economic prosperity is not seen as an integral part of sustainable development, the lack of motivation and urgency to work on sustainable development can be better understood. Therefore, an information campaign should be combined with actions such as legislation, taxing, subsidising, visioning, creation of an adaptive governance structure, open organisation around themes and processes, and cooperation between stakeholders. Government's role is to coordinate, facilitate and monitor.

All in all, this thesis shows that many barriers to the implementation of sustainable development exist. It also provides ideas for solutions. The provincial or regional level seems to be well placed to take serious steps towards a sustainable future and to function as a frontrunner for the national level regarding implementation of sustainable development. A first step would be to develop a future oriented vision that uses sustainable development as its guiding principle. 



\section{Samenvatting}

Op verschillende schaalniveaus is een kloof zichtbaar tussen duurzaamheidbeleid en implementatie. Dit proefschrift onderzoekt die implementatiekloof van duurzame ontwikkeling in de Provincie Limburg. Het concept van duurzame ontwikkeling vereist dat we de planeet en onze wereld als systeem zien. Een systeem dat plaatsen met elkaar verbindt (hier en elders) en een systeem dat tijd met elkaar verbindt (nu en later). Een centraal kenmerk van duurzame ontwikkeling is dat we een integrale visie aannemen. Tegelijkertijd kan duurzame ontwikkeling gezien worden als een politiek of normatieve kwestie, in plaats van een wetenschappelijk concept. Duurzame ontwikkeling gaat tenslotte om de leefkwaliteit die wij ambiëren, nu en in de toekomst. Die gewenste toekomst zal verschillen van plaats tot plaats en van persoon tot persoon. Daarom moeten we accepteren dat er veel verschillende visies op duurzame ontwikkeling zijn. De kracht van het concept is juist dat het verschillen in de wereld en in handelen naar de oppervlakte brengt in de vorm van wereldbeelden en tegenstrijdigheden in gangbaar gedrag, waardoor een speelveld voor het debat ontstaat.

Gevolgen van onduurzaam handelen worden vaak elders of pas op de lange termijn zichtbaar, terwijl bijvoorbeeld een storing in de watervoorziening directe voelbare gevolgen heeft. Duurzame ontwikkeling wordt gedragen door de overheid en maatschappij, maar een echt gevoel van urgentie dat leidt tot actie lijkt te ontbreken. Individuele voordelen die duidelijk zijn in het geval van riolering of gezondheidszorg zijn niet zo hel;der bij duurzame ontwikkeling. In zo'n geval is er sturing nodig om vorm te geven aan het maatschappelijke proces voor een verandering naar duurzame ontwikkeling.

Sturing van duurzame ontwikkeling heeft te maken met onzekerheden, een onduidelijke verdeling van verantwoordelijkheid voor allerlei oorzaken en gevolgen, complexiteit op het systeemniveau en tussen actoren en sectoren, grote tijds- en ruimtelijke dimensies, en de mogelijke onomkeerbaarheid van processen. In dit proefschrift is een theoretisch kader ontwikkeld om beter te kunnen begrijpen wat de barrières zijn die we tegenkomen in de implementatie van duurzaamheidbeleid. Dit raamwerk brengt in kaart wat de verschillende manieren van sturing zijn en de perspectieven op duurzame ontwikkeling. (Hoofdstuk 2) Sturing van duurzame ontwikkeling heeft dynamische probleemoplossingen nodig, integratie van informatie, deelname van actoren op allerlei schaalniveaus, coördinatie dwars door beleidsgebieden heen, en visie, doelen, voordelen en tastbaarheid. Alles bij elkaar is dit niet eenvoudig. Maar wat zijn nou eigenlijk die problemen die we tegenwoordig het hoofd moeten bieden? Om het antwoord te vinden onderzoekt dit proefschrift barrières voor het implementeren van duurzame ontwikkeling in de praktijk 
vanuit verschillende perspectieven: beleid, bevolking, praktijkmensen en monitoring.

\section{Duurzaamheidbeleid (hoofdstuk 3)}

In de laatste decennia is er beleid ontwikkeld dat specifiek is gericht op duurzame ontwikkeling. Vooral sinds hun verplichting aan het Implementatieplan van de Johannesburgconferentie in 2002 hebben veel landen een nationale duurzaamheidstrategie ontwikkeld. In dit proefschrift is gekeken naar verschillende beleidsdocumenten op het gebeid van duurzame ontwikkeling op verschillende schaalniveaus. de sterke en zwakke punten van deze beleidsstukken zijn onderzocht, en de vraag is gesteld of duurzame ontwikkeling specifiek beleid nodig heeft, of dat het beter zou zijn om duurzame ontwikkeling als leidende principe te gebruiken en wat dat dan betekent.

Twee opmerkingen kunnen gemaakt worden over duurzaamheidbeleid: gedurende lange tijd werd duurzaamheid gezien vanuit een milieuperspectief, zelfs nog na de Rio Conferentie waar duurzame ontwikkeling geïntroduceerd werd als een integrerend interdisciplinair concept dat zich bezighoudt met gelijkheidsprincipes binnen en tussen generaties. Tevens zagen we dat het veel tijd kost om van een mondiaal vraagstuk tot regionaal beleid te komen.

De Limburgse duurzaamheidstrategie is onderzocht binnen de nationale en Europese context: de Europese duurzaamheidstrategie ${ }^{29}$, de Kabinetsaanpak Duurzame Ontwikkeling $^{30}$ en de Limburgse duurzaamheidstrategie ${ }^{31}$. Elk van deze beleidsstukken heeft integratie als uitgangspunt: duurzame ontwikkeling is een verbindend concept en is een proces meer dan iets anders. Echter, analyse toonde aan dat deze beleidsstukken juist een barrière zijn voor een geïntegreerde benadering door hun gebrek aan verbinding tussen schaalniveaus, hun focus op milieu en hun benadering waarbij duurzame ontwikkeling en bijbehorende demonstratieprojecten in een speciale niche wordt geplaatst. Daarom vervolgt dit proefschrift met de vraag wat het zou betekenen als het beleid daadwerkelijk integratie nastreeft en duurzame ontwikkeling zou operationaliseren als een verbindend concept dat alle sectoren doorsnijdt. Dat zou betekenen dat elke actie, elk ontwerp, elk productieproces en elke beslissing genomen wordt in het licht van duurzame ontwikkeling. Hiervoor is ten eerste een brede visie op de gewenste toekomst van belang. Vervolgens moeten beleid en acties ontworpen worden om die visie te realiseren. Beleid en acties, evenals de toekomstvisie, moeten een duurzaamheidscheck ondergaan. In plaats van het bepalen van strategische uitdagingen voor duurzame ontwikkeling, zoals nu gangbaar is, moeten strategische doelen benoemd worden zodat de maatschappij haar gewenste kan bereiken. Het is essentieel te begrijpen dat duurzame

\footnotetext{
${ }^{29}$ EU 10917/06 Renewed EU sustainable development strategy

${ }^{30}$ VROM DGM/BREM2008050615 Kabinetsaanpak Duurzame Ontwikkeling (KADO)

${ }^{31}$ Provincie Limburg, Beleidskader Duurzame Ontwikkeling/ Cradle to Cradle 2008-2011
} 
ontwikkeling niet het doel is, maar het middel om de gewenste toekomst te bereiken. Een checklist voor duurzame ontwikkeling is in dit proefschrift ontwikkeld om te helpen bij een duurzaamheidscheck van visie, beleid en actie. Nieuwe wegen voor implementatie kunnen ingeslagen worden als duurzame ontwikkeling gebruikt wordt als een richtinggevend principe, met bijbehorende criteria die toegepast worden op elk beleid en elke actie.

\section{De Limburgse bevolking (hoofdstuk 4)}

Implementatie van duurzame ontwikkeling behoeft samenwerking van actoren van de overheid, markt en maatschappij. Het is bekend dat burgers denken dat de overheid het voortouw moet nemen bij duurzame ontwikkeling en een voorbeeld moet zijn. Maar de overheid kan duurzame ontwikkeling niet alleen implementeren. Een aanname in dit onderzoek was dat een reden waarom implementatie mislukt is omdat mensen het concept duurzame ontwikkeling niet kennen, omdat het concept te abstract is en niet goed wordt begrepen. Desondanks werd ook aangenomen dat mensen wel duurzame dingen doen zonder het zo te noemen. Om antwoorden op deze vragen en aannames te vinden is een survey gehouden in Limburg. Een vragenlijst per internet is aan 1281 mensen uitgestuurd, waarvan 910 geantwoord hebben.

De belangrijkste conclusies van de survey waren dat mensen duurzame ontwikkeling begrijpen op een abstract niveau, maar het interpreteren als milieu op een concreet niveau. Mensen vinden duurzame ontwikkeling belangrijk. Economie wordt niet gezien als een belangrijke dimensie van duurzame ontwikkeling.

De vraag of mensen wel duurzaam gedrag vertonen maar het niet zo noemen, liet zien dat mensen zeggen dat ze duurzaam zijn en dat ze zelfs nog duurzamer willen worden, maar zich (nog) niet duurzaam gedragen. Hun gedrag is vooral bepaald door kwaliteit- en kostenoverwegingen.

Wat betreft leiderschap in duurzame ontwikkeling zien mensen inderdaad de overheid als meest belangrijke speler om het voortouw te nemen, maar ze zien ook een rol voor andere spelers. Visie vormen en doelen stellen wordt gezien als het belangrijkste instrument voor alle stakeholders, gevolgd door het nemen van actie.

Niet alleen lieten de resultaten zien wat de huidige status van duurzaamheidsdenken in Limburg is, maar ook zagen we vele mogelijkheden voor verbetering.

Ten eerste is het duidelijk dat informatie over duurzame ontwikkeling nodig is. In detail betekent dit dat mensen af moeten weten van de afhankelijkheid van de sociale, economische en ecologische domeinen en tijd en ruimte. Verder hebben ze informatie nodig over individuele voordelen, de effecten van duurzaam gedrag en voorbeelden van concrete acties die ze kunnen nemen.

Ten tweede kunnen de acties die mensen ondernemen duurzamer gemaakt worden door de duurzame optie de gemakkelijkste te maken, door productinformatie te geven, mensen te helpen het duurzaamheidgehalte van hun acties te bepalen, 
en door alternatieve mobiliteitsopties te bieden die snelheid en bereikbaarheid garanderen.

Ten derde kan een omgeving gecreëerd worden die het mogelijk maakt om deze veranderingen te realiseren. Omdat de overheid als zo belangrijk wordt gezien, en omdat duurzame ontwikkeling zo'n langdurige kwestie is, lijkt de overheid de ideale kandidaat om zo'n faciliterende omgeving te creëren. Daarbij moet de overheid een visie ontwikkelen, doelen stellen actie nemen en voorzien in wet- en regelgeving. Het opstellen van een visie en doelen, en actie ondernemen, werd overigens gezien als belangrijk voor alle actoren. Maar alle partijen hebben ook specifieke taken.

In het algemeen is het duidelijk geworden dat verschillende groepen een verschillende manier van aanpak nodig hebben, bijvoorbeeld afhankelijk van leeftijd, geslacht, opleiding.

Het is belangrijk om in te zien dat de drie clusters, informatievoorziening, actie stimuleren, en een faciliterende omgeving, met elkaar samenhangen en elkaar versterken en daarom parallel aangepakt moeten worden.

\section{Het perspectief van de praktijk (hoofdstuk 5)}

Om meer te weten te komen over de huidige belemmeringen voor duurzame ontwikkeling, zijn praktijkmensen ondervraagd naar hun ervaringen in twee case studies in Limburg: Greenport Venlo (GV) en het programma Leren voor Duurzame Ontwikkeling (LvDO). Deze casussen zijn gekozen vanwege hun verschillende sturingsbenadering van regionale (duurzame) ontwikkeling. Greenport Venlo is een vrijwillig opgezette netwerkorganisatie die gekenmerkt wordt door deliberatie. Leren voor Duurzame Ontwikkeling is een overheidgestuurd programma dat een meer traditionele top-down benadering volgt. De analyse van de twee casussen richtte zich op de verschillen en overeenkomsten ertussen om daardoor meer te leren over de huidige problemen en praktijken. Vragen richtten zich op de manier van sturing, het perspectief op duurzame ontwikkeling en problemen en oplossingen in de case studies.

Inhoudelijk gezien is het probleem niet zozeer welk duurzaamheidperspectief gehanteerd wordt, maar dat het doel vaag is, en voordelen onduidelijk zijn, waardoor het erg moeilijk wordt om te communiceren met mensen. Het merendeel van de problemen heeft te maken met sturingskwesties (instituties, actoren, processen en instrumenten). Meer specifiek gaat het erom dat actoren niet altijd bereikt kunnen worden, of dat ze niet betrokken zijn bij of geïnteresseerd zijn in duurzame ontwikkeling. Belangrijke vaardigheden voor proces facilitatoren zijn niet altijd aanwezig in overheidsinstanties. Spanning bestaat tussen nieuwe deliberatieve benaderingen en hiërarchische structuren. Het probleem is hoe structuur te geven is en tegelijk innovatieruimte te behouden. In LvDO wordt deze spanning geuit in een angst, of tegenzin, voor verandering binnen de provinciale organisatie. 
De meeste praktijken, ofwel de acties die ondernomen worden om de projecten in de case studies tot een succes te maken, hebben met sturing te maken. Dit betekent niet dat duurzame ontwikkeling minder belangrijk is dan sturing. Duurzame ontwikkeling vereist visie en duidelijkheid over de richting die genome moet worden. Maar het bereiken van duurzame ontwikkeling is een complexe sturingskwestie. Weinig verassend is dat veel van de praktijken zich richtten op stakeholders. In beide cases zagen we dat stakeholders erg belangrijk zijn. Als zij niet meedoen zal er weinig gebeuren. Daarom zijn procesfacilitatoren nodig met de juiste vaardigheden. Ze moeten in staat zijn om stakeholders te motiveren, te bemiddelen waar nodig, verbindingen te leggen, moeilijke processen te faciliteren, informatie verstrekken, reflecteren op processen, enz. Een mix van benaderingen (hiërarchisch en deliberatief) wordt gebruikt en verschillende types meetings en organisatievormen worden gebruikt.

Wat betreft overeenkomsten en verschillen tussen de case studies kunnen we stellen dat het duurzaamheidperspectief dat gehanteerd is een well-being perspectief is, dat in de praktijk benaderd lijkt te worden als milieu. Dit is niet anders dan wat in andere hoofdstukken is gevonden. In GV wordt met name gezocht naar structuur, maar tegelijk naar openheid benodigd voor innovatie. GV heeft baat gehad bij het proces dat resulteerde in een visiedocument. In LvDO was de structuur geen probleem, omdat die helder was. In plaats daarvan waren vooral het verkrijgen van engagement en interesse bij stakeholders van belang.

Wat kunnen we leren van deze resultaten? De nadruk die in beide case studies op sturing wordt gelegd is een uitdrukking van de complexiteit van duurzame ontwikkeling. Als duurzame ontwikkeling makkelijker zou zijn, dan waren er minder sturingsvragen bij betrokken. De duurzaamheidvisie, -doelen en -voordelen helderder maken, zal niet alle sturingsvraagstukken oplossen, maar zal wel helpen om scherp te stellen op wat echt belangrijk is: het vinden van nieuwe sturingsvormen om naar duurzame ontwikkeling toe te werken. Daarbij is het belangrijk een mix van sturingsvormen te hanteren waarbij niet vergeten mag worden dat nieuwe sturingsvormen de "oude" instituties niet moeten vergeten. Tegelijk is duidelijk dat de oude sturingsstructuren niet geschikt zijn voor duurzame ontwikkeling.

Duurzame ontwikkeling gaat over leven, werken en handelen op een andere manier. Als we zo'n proces willen sturen. Dan hebben we te maken met een lastige kwestie waar geen blauwdruk voor een oplossing voor te vinden is. Dit betekent een nieuwe rol voor de overheid in het scheppen van een faciliterende omgeving waar implementatie plaats kan vinden.

\section{Monitoren van duurzame ontwikkeling (hoofdstukken 6 en 7)}

Omdat de resultaten van duurzaamheidacties vaak pas zichtbaar worden na lange tijd is het belangrijk de implementatie van processen te monitoren terwijl ze gaande zijn. Voortdurende beoordeling helpt om voortgang zichtbaar te maken en pro- 
cessen in de juiste richting te sturen. Het meten van regionale duurzame ontwikkeling bevat verschillende elementen: capaciteit voor flexibiliteit, waaronder een set van regiospecifieke karakteristieken, een goede systeembeschrijving, en een visie voor duurzame ontwikkeling die regionale prioriteiten vaststelt. Als eenmaal deze elementen aanwezig zijn, is het mogelijk om kan regionale duurzame ontwikkeling beoordeeld worden. Toen we echter monitoring voor de Limburgmonitor 2007 gingen doen, bleek dat beleid in Limburg een lange termijnvisie op regionale duurzame ontwikkeling ontbeerde.

De expertgroep die werkte aan regionale monitoring wilde niet in botsing komen met wat haar leden zagen als een taak voor het bestuur, door zelf prioriteiten voor duurzame ontwikkeling in Limburg op te stellen. Daardoor bleef het regionale raamwerk vrij vaag en was eenvoudigweg gebaseerd op de drie pijlers van duurzame ontwikkeling, wat een concept is dat al in Limburg werd gebruikt: maatschappij, economie en ecologie. Daarbovenop was de afwezigheid van doelen en criteria voor interpretatie een belangrijke barrière voor het uitvoeren van een succesvol duurzaamheidsassessment. Vanwege de afwezigheid van bestuurlijke input in het proces, kwamen er problemen in verschillende stadia van het monitoringproces. Dit monitoringproject maakte duidelijk dat in elk stadium van het meten van duurzame ontwikkeling de betrokkenheid en medewerking van zowel relevante bestuurders als technische experts belangrijk is.

\section{Conclusie (hoofdstuk 8)}

Duurzame ontwikkeling is een complex proces dat een integrale benadering nodig heeft. Dit is op zichzelf al een barrière voor implementatie. Maar complexiteit kan beheersbaar gemaakt worden. Voor duurzame ontwikkeling betekent dit dat er een visie is op de gewenste toekomst en gerelateerd daaraan dat er doelen zijn benoemd. Maar juist een visie en doelen ontbreken vaak in beleid op verschillende niveaus ook al zien stakeholders het als heel belangrijk dat er visie en doelen zijn bij alle stakeholders. Nu is er vaak een algemene visie van een land of regio en daarnaast soms een duurzaamheidvisie. Het zou raadzaam zijn een algemene visie van de toekomst de maken op elk schaalniveau waarbij duurzame ontwikkeling als leidend principe wordt gehanteerd. De reden hiervoor is dat het vanwege de geïntegreerdheid van het concept weinig zin heeft om het op te sluiten in zijn eigen niche met zijn eigen beperkte visie. Het heeft verder weinig zin om een duurzaamheidvisie voor een land of regio te maken die anders is dan de algemene visie.

Verder kan er met complexiteit omgegaan worden door een complexe kwestie op te delen in kleinere stukken waarop actie ondernomen wordt. Dit gebeurt wel, maar de resultaten worden niet samengebracht om voortgang ten opzichte van de gewenste toekomst af te zetten. Het is essentieel dat gedurende het implementatieproces de resultaten van de ondernomen acties geëvalueerd worden vanuit de visie en doelen om voortgang naar het bereiken van de visie te zien. 
Wat er ook ontbreekt is een faciliterende omgeving die helpt om duurzame ontwikkeling te implementeren. Zo'n omgeving helpt duurzame ontwikkeling, in plaats van het tegen te werken door visie en coördinatie te geven waar dat nodig is. Zo'n omgeving stimuleert actie, verbindt mensen, en biedt structuur en ruimte voor innovatie. Proces managers met de juiste vaardigheden zijn erg belangrijk.

Een mix van hiërarchische en deliberatieve benaderingen is nodig. Structuur is nodig maar ook ruimte voor innovatie. Als alternatief voor het maken van nieuwe instituties lijkt het praktischer om benodigde thema's processen en rollen te definieren en daar omheen groepen te formeren. Na elke herziening van de gewenste toekomst en de wegen om die te bereiken zullen waarschijnlijk nieuwe rollen en processen nodig zijn, wat betekent dat een flexibele en adaptieve structuur belangrijk is. We denken dat een kerninstelling zoals de provinciale administratie nodig is als coördinator en facilitator, met de bekwaamheid om verschillende partijen te verbinden en met de verantwoordelijkheid om monitoring te borgen.

Op dit moment is milieubewustzijn de trend, maar duurzaamheidbewustzijn niet. We zagen in beleid een vrij onduidelijke manier van denken over duurzame ontwikkeling. Dit helpt niet om duurzame ontwikkeling te implementeren. Het lijkt erop dat het volledige concept met zijn geïntegreerde benadering en tijds- en ruimtelijke relaties nog niet is geland. Omdat duurzame ontwikkeling gepresenteerd wordt als well-being, maar geïmplementeerd wordt als milieubescherming, is een inconsistent perspectief van duurzame ontwikkeling het gevolg. Voor een onderwerp dat al zo complex is en dat onderwerp is van debat, is het voor de hand liggend dat zo'n inconsistentie de vaagheid alleen maar vergroot.

Een andere belangrijke barrière voor meer duurzaam gedrag is het gebrek aan kennis over concrete acties die mensen kunnen nemen, wat verholpen kan worden door een informatiecampagne. Maar veel mensen zeggen dat ze alleen maar in actie willen komen als de voordelen helder zijn. Met andere woorden, ze vragen om incentives om duurzamer te worden. Tegelijk gaven mensen aan dat ze wilden veranderen op een makkelijke manier. Omdat de voordelen van duurzaam gedrag waarschijnlijk pas wat opleveren op de lange termijn, en waarschijnlijk eerder op het collectieve in plaats van het individuele niveau, zal een informatiecampagne alleen niet resulteren in meer duurzame actie. Maar er is een keerzijde aan de vraag om incentives. Ook al begrijpen mensen op een abstract niveau wel dat duurzame ontwikkeling een balans tussen economische, maatschappelijke en milieuontwikkeling, werd economie op concreet niveau nauwelijks genoemd als belangrijk bij duurzame ontwikkeling. Dit betekent dat toen mensen gevraagd werden om concrete voorbeelden van duurzame ontwikkeling, economie niet werd genoemd. De acties van mensen zijn echter grotendeels bepaald door economische overwegingen en kwaliteit. Als economische voorspoed niet wordt gezien als een integraal onderdeel van duurzame ontwikkeling dan kan het gebrek aan motivatie en urgentie om te werken aan duurzame ontwikkeling beter begrepen worden. Daarom 
moet een informatiecampagne vergezeld gaan van acties zoals wet- en regelgeving, belasting, subsidies, visievorming, het ontwerpen van een adaptieve sturingstructuur, open organisatie rond thema's en processen en samenwerking tussen stakeholders. De rol van de overheid is om te coördineren en te monitoren.

In het geheel laat dit proefschrift zien dat er vele barrières bestaan voor de implementatie van duurzame ontwikkeling. Het biedt ook ideeën voor oplossingen. Het provinciale of regionale niveau lijkt goed geschikt te zijn om een serieuze stap richting duurzame ontwikkeling te nemen en te functioneren als een koploper voor het nationale niveau wat betreft duurzame ontwikkeling. Een eerste stap zou zijn een toekomstgeoriënteerde visie te ontwikkelen die duurzame ontwikkeling gebruikt als leidend principe. 


\section{Acknowledgements}

Working on this thesis was a journey. Along the way I gained new insights and new knowledge. I learned a lot about "doing science": checking and rechecking the facts, finding references, careful phrasing, translating scientific questions into a survey and a questionnaire, writing articles for scientific journals and participating in conferences. While travelling though academia, I was convinced that my work had to contribute to answering societal questions. Not only to keep the donors happy, or to make sure my work would be read by a few more people than an exclusive group of colleagues, but because I wanted to create something useful. I am proud of the work that lies in front of you because I think that I have achieved that goal.

Of course this work has been facilitated by a great number of people. First of all, I would like to thank my promotor and co-promotor, respectively Pim Martens and Ron Cörvers, for their constructive discussions and comments. Pim, your door is always open, which I appreciate. Ron, your drawings often forced me to shift my mindset. Both of you allowed me a lot of freedom to pursue my goals.

Financial support was given by the Province of Limburg through the project "Governance for sustainable development, the case of Limburg, the Netherlands" and the 6th framework programme of the European Commission through the project "INSURE: Flexible Framework for Indicators for Sustainability in Regions, Using System Dynamics Modelling". I am most grateful to both organisations.

My research would have been utterly impossible without the people willing to participate in the survey and questionnaire. A warm thank you to all (about 1000 people)! Pleun Aardening from Internet Research Bureau Flycatcher, you have been a very pleasant and helpful sparring partner.

The working environment at ICIS was, and is, conducive to sustainable development research. Many different backgrounds and friendly people allow for rich discussions that move from the professional to the personal and back. Dear colleagues, many thanks! For special thanks I mention my former roommate Machiel Lamers for our discussions and laughs. Special thanks also to Annet Grol and Anja van Bogaert for keeping ICIS running.

I had a variety of contacts within the provincial administration who were at one time or another involved in the project. I would like to mention here Harma Albering, Robert Engelen, Ad Himmelreich, Bert Kersten, Paul Levels, Wendy de Natris, Dick van Nierop, Sjoerd Reijsenbach de Haan and Dennis Roijen.

Throughout my journey I have been accompanied by two very important people: Gilbert, my husband, and Roos, my great daughter. Lieve Gilbert en Roos, jullie hebben heel wat te stellen gehad met een bij tijd en wijle zeer afwezige promo- 
venda in huis. Verstrooide professor noemden jullie me als ik weer eens gekke dingen zei. Afwezig van alles beamen en vervolgens ontkennen dat ik er ooit iets van had gehoord, kwam ook wel eens voor. Ik kan niet garanderen dat dat nooit meer gebeurt, maar ik ga wel mijn best doen iets minder verstrooid te zijn. Jullie hebben mij geweldig geholpen, gewoon door er te zijn!

Last, but not least, from an early age on, I was encouraged by my parents to choose my own path. Thank you for your trust and your encouragement and your willingness always to think along with me.

A journey this was, not only in a metaphorical way, but also physically. I have been to many places for conferences and project meetings. I sat with my computer in many different locations including a holiday house, airports, a bar, home, my parents' place, and a few more. That is one thing in sustainability research: if you have access to a computer, internet and the people, who are the core of sustainable development, you can work everywhere! 


\section{About the author}

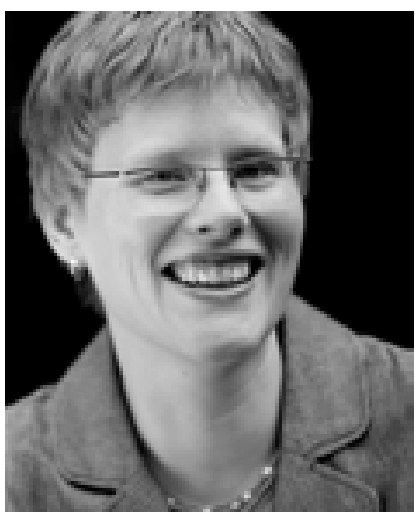

Annemarie van Zeijl-Rozema was born in 1971 in Zuidhorn, the Netherlands. In 1989 she obtained her European Baccalaureate from the European School of Luxembourg and started her master studies in Tropical Land Use at Wageningen University in the Netherlands. During her studies she conducted six months of field work at the EU funded Copperbelt Smallholder Development Project in Zambia. In 1995 she finished her studies and graduated from Wageningen University. She started her working career in Wageningen as co-organiser of the first meeting of the IGBP-IHDP Land Use and Cover Change programme (LUCC) in 1996. Then she became the programme manager of an EU funded project on land use data. In 1997 she moved to Yemen to work as an Associate Professional Officer for the field office of the United Nation's Food and Agriculture Organization (FAO) in Sana'a. She coordinated FAO projects on management of natural resources. In 1999 she started her second term with FAO at headquarters in Rome as a member of the Executive Bureau preparing the FAO-Netherlands conference on the multifunctional character of agriculture and land. In 2001 she moved back to the Netherlands where she landed in Maastricht. After various (free-lance) jobs with Maastricht University she started in 2004 at the university's sustainability institute ICIS (International Centre for Integrated assessment and Sustainable development) to work on integrated monitoring of sustainable development. Soon after her arrival she helped to formulate a research proposal with the Province of Limburg to investigate the governance of sustainable development within the province. Her monitoring work and the provincial project resulted in underlying PhD thesis. Currently, she is working on an NWO funded post-doc project that investigates the coproduction of knowledge between science and policy in sustainable development and climate change. She is also involved in an EU-funded project on harnessing research for sustainable development. She set up a master course on governance for sustainable development and taught this course for several years. Her research interests lie in the field of building bridges between science and policy, regional sustainable development and implementing sustainable development. 